\title{
Analysis of Operating Alternatives for the Naval Computer and Telecommunications Station Cogeneration Facility at Naval Air Station North Island, San Diego, California
}

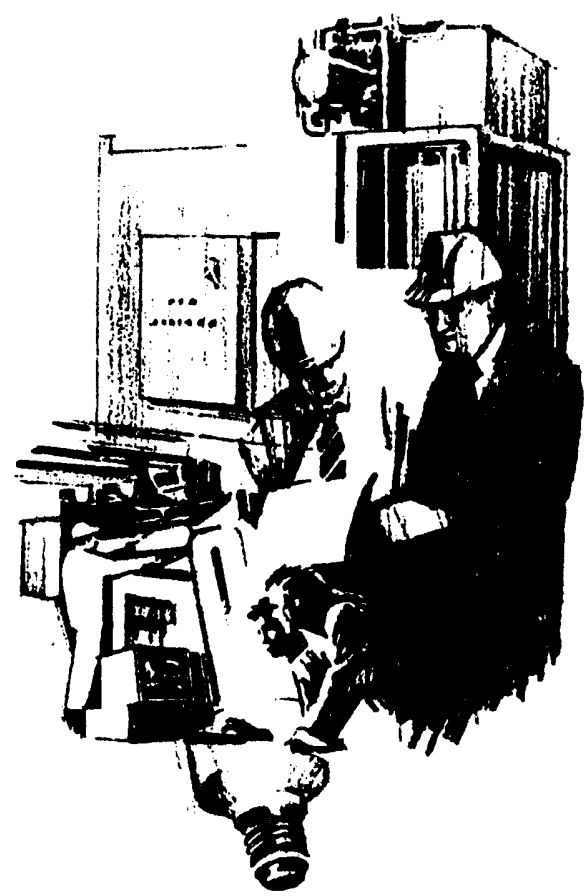

December 1993

Prepared for the U.S. Department of Energy Federal Energy Management Program under Contract DE-AC06-76RLO 1830

Pacific Northwest Laboratory Operated for the U.S. Department of Energy by Battelle Memorial Institute 


\title{
DISCLAIMER
}

This report was prepared as an account of work sponsored by an agency of the United States Government. Neither the United States Government nor any agency thereof, nor Battelle Memorial Institute, nor any of their employees, makes any warranty, expressed or implied, or assumes any legal liability or responsibility for the accuracy, completeness, or usefulness of any information, apparatus, product, or process disclosed, or represents that its use would not infringe privately owned rights. Reference herein to any specific commercial product, process, or service by trade name, trademark, manufacturer, or otherwise does not necessarily constitute or imply its endorsement, recommendation, or favoring by the United States Government or any agency thereof, or Battelle Memorial Institute. The views and opinions of authors expressed herein do not necessarily state or reflect those of the United States Government or any agency thereof.

\author{
PACIFIC NORTHWEST LABORATORY \\ operated by \\ BATTELLE MEMORIAL INSTITUTE \\ for the \\ UNITED STATES DEPARTMENT OF ENERGY \\ under Contract DE-ACO6-76RLO 1830
}

Printed in the United States of America

Available to DOE and DOE contractors from the

Office of Scientific and Technical Information, P.O. Box 62, Oak Ridge, TN 37831; prices available from (615) 576-8401. FTS 626-8401.

Available to the public from the National Technical Information Service, U.S. Department of Commerce, 5285 Port Royal Rd., Springfield, VA 22161. 


\title{
Analysis of Operating Alternatives for the Naval Computer and Telecommunications Station Cogeneration Facility at Naval Air Station North Island, San Diego, California
}

\author{
S. A. Parker \\ D. M. Carroll \\ K. L. McMordie \\ D. R. Brown \\ K. K. Daellenbach \\ S. A. Shaunde \\ D. J. Stucky
}

December 1993

Prepared for

the U.S. Department of Energy

Federal Energy Management Program

under Contract DE-AC06-76RLO 1830

Pacific Northwest Laboratory

Richland, Washington 99352 


\section{Preface}

The goal of the U.S. Department of Energy (DOE) Federal Energy Management Program (FEMP) is to facilitate energy efficiency improvements at federal facilities. This is accomplished by a balanced program of technology development, facility assessment, and use of cost-sharing procurement mechanisms. Technology development focuses upon the tools, software, and procedures used to identify and evaluate energy efficiency technologies and improvements. For facility assessment, FEMP provides metering equipment and trained analysts to federal agencies exhibiting a commitment to improve energy use efficiency. To assist in procurement of energy efficiency measures, FEMP helps federal agencies devise and implement performance contracting and utility demand-side management strategies.

Pacific Northwest Laboratory (PNL) $)^{(\omega)}$ supports the FEMP mission of energy systems modernization. Under this charter, the Laboratory and its contractors work with federal facility energy managers to assess and implement energy efficiency improvements at federal facilities nationwide.

The Southwestern Division of the U.S. Navy (USN), Naval Facilities Engineering Command, in cooperation with FEMP, has tasked PNL to assess the economics and engineering feasibility of continuing to operate a cogeneration plan at the Naval Computer and Telecommunications Station (NCTS) at the Naval Air Station North Island (NASNI). The recommendations resulting from that assessment are presented in this report.

(a) Pacific Northwest Laboratory is operated by Battelle Memorial Institute for the U.S. Department of Energy under Contract DE-AC06-76RLO 1830. 


\begin{abstract}
The Naval Facilities Engineering Command Southwestern Division commissioned Pacific Northwest Laboratory (PNL), in support of the U.S. Department of Energy (DOE) Federal Energy Management Program (FEMP), to determine the most cost-effective approach to the operation of the cogeneration facility in the Naval Computer and Telecommunications Station (NCTS) at the Naval Air Station North Island (NASNI). Nineteen alternative scenarios were analyzed by PNL on a life-cycle cost basis to determine whether to continue operating the cogeneration facility or convert the plant to emergency-generator status.
\end{abstract}

This report provides the results of the analysis performed by PNL for the 19 alternative scenarios. A narrative description of each scenario is provided, including information on the prime mover, electrical generating efficiency, thermal recovery efficiency, operational labor, and backup energy strategy. Descriptions of the energy and energy cost analysis, operations and maintenance (O\&M) costs, emissions and related costs, and implementation costs are also provided for each alternative. A summary table presents the operational cost of each scenario and presents the result of the life-cycle cost analysis. 


\section{Executive Summary}

The Naval Facilities Engineering Command Southwestern Division commissioned Pacific Northwest Laboratory (PNL), in support of the U.S. Department of Energy (DOE) Federal Energy Management Program (FEMP), to determine the most cost-effective approach to the operation of the cogeneration facility in the Naval Computer and Telecommunications Station (NCTS) at the Naval Air Station North Island (NASNI). This report describes 19 alternative scenarios for the cogeneration facility, provides an engineering and economic analysis, and presents a life-cycle cost analysis for each of the scenarios. Analysis results are presented for each major cost category (e.g., energy, operations and maintenance [O\&M], emissions, and implementation).

Table S.1 provides the results of the life-cycle cost analysis in 1995 dollars for the 19 scenarios ranked from best (top) to worst (bottom). The life-cycle cost analysis is performed in 1995 dollars because it is assumed that implementation will actually occur during fiscal year (FY) 1995. Table S.2 provides a summary of the major cost components in 1993 dollars (the year of this report) for each of the alternative scenarios.

Scenarios 17 and 19 have the highest net savings, $\$ 15,082,000$ and $\$ 14,911,000$, respectively-compared to the existing system (Scenario 1). These scenarios involve repairing the existing reciprocating engines and converting them to act as emergency generators, providing emergency backup to the electric energy systems. San Diego Gas \& Electric (SDG\&E) provides the NCTS facility with primary electric service, and Applied Energy Incorporated (AEI) provides primary thermal energy. In Scenario 17, the emergency generators also supply backup thermal energy through waste-heat recovery from the generators. In Scenario 19, backup thermal energy is supplied by a new fast-response boiler. Because the NCTS facility requires a backup thermal source with a 15-minute response time to avoid a thermally activated shutdown of the computer systems, Scenario 19 is the preferred technical alternative.

Both scenarios assume that the U.S. Navy (USN) incorporates the SDG\&E Interruptible Schedule I-3, Rate A. This rate schedule allows SDG\&E to give the USN 10-minutes' notice, by telephone, to start the emergency generators remotely for the purpose of reducing SDG\&E's system peak demand. 
Table S.1. Summary of Life-Cycle Cost Analysis in 1995 Dollars

\begin{tabular}{|c|c|c|}
\hline Scenario & $\begin{array}{c}\text { Life-Cycle Cost } \\
(\$)\end{array}$ & $\begin{array}{c}\text { Net Savings } \\
(\$) \\
\end{array}$ \\
\hline 17 & $(2,560,000)$ & $15,082,000$ \\
\hline 19 & $(2,389,000)$ & $14,911,000$ \\
\hline 16 & $(1,430,000)$ & $13,952,000$ \\
\hline 18 & $(1,259,000)$ & $13,781,000$ \\
\hline 13 & 898,000 & $11,624,000$ \\
\hline 14 & $1,069,000$ & $11,453,000$ \\
\hline 15 & $2,969,000$ & $9,553,000$ \\
\hline 6 & $4,319,000$ & $8,203,000$ \\
\hline 9 & $5,417,000$ & $7,105,000$ \\
\hline 3 & $8,322,000$ & $4,200,000$ \\
\hline 8 & $9,222,000$ & $3,300,000$ \\
\hline 2 & $9,233,000$ & $3,289,000$ \\
\hline 2 & $9,286,000$ & $3,236,000$ \\
\hline 5 & $10,073,000$ & $2,449,000$ \\
\hline 1 & $12,522,000$ & Base Case \\
\hline 7 & $13,897,000$ & $(1,375,000)$ \\
\hline 4 & $14,988,000$ & $(2,466,000)$ \\
\hline 11 & $16,099,000$ & $(3,577,000)$ \\
\hline 10 & $28,923,000$ & $(16,401,000)$ \\
\hline
\end{tabular}


Table S.2. Summary of Major Cost Components in 1993 Dollars

\begin{tabular}{|c|c|c|c|c|c|c|}
\hline Scenario & $\begin{array}{c}\text { Net Energy } \\
\text { Savings } \\
(\mathbf{S} / \mathrm{yr}) \\
\end{array}$ & $\begin{array}{c}\text { PWCSD }^{(a)} \\
\text { Labor } \\
\text { Cost }(\mathbf{S} / \mathbf{y r}) \\
\end{array}$ & $\begin{array}{c}\text { Total } \\
\text { Maintenance } \\
\text { Cost }(\$ / y r) \\
\end{array}$ & $\begin{array}{c}\text { Emission } \\
\text { Pees (S/yr) }\end{array}$ & $\begin{array}{l}\text { Potential } \\
\text { Emissions } \\
\text { Credit (\$) } \\
\end{array}$ & $\begin{array}{c}\text { Implementation } \\
\text { Cost }(\$) \\
\end{array}$ \\
\hline 1 & 150,136 & 309,254 & 258,005 & 10,724 & 0 & 0 \\
\hline 2 & 152,696 & 309,254 & 201,477 & 10,724 & 239,898 & 0 \\
\hline 3 & 110,751 & 309,254 & 166,558 & 10,724 & 388,092 & 0 \\
\hline 4 & 182,018 & 309,254 & 338,904 & 10,724 & 13,328 & 54,525 \\
\hline 5 & 269,291 & 265,980 & 239,159 & 10,724 & 246,101 & 90,475 \\
\hline 6 & 234,477 & 154,610 & 177,545 & 10,724 & 389,886 & 90,475 \\
\hline 7 & 416,381 & 309,254 & 338,904 & 10,724 & 13,328 & $1,830,000$ \\
\hline 8 & 382,788 & 265,980 & 239,159 & 10,724 & 246,101 & $1,865,950$ \\
\hline 9 & 271,452 & 154,610 & 177,545 & 10,724 & 389,886 & $1,865,950$ \\
\hline 10 & $(37,689)$ & 309,254 & 259,497 & 5,362 & 13,328 & $5,554,000$ \\
\hline 11 & 220,889 & 265,980 & 197,340 & 5,362 & 246,101 & $5,589,950$ \\
\hline 12 & 266,731 & 154,610 & 158,951 & 5,362 & 389,886 & $5,589,950$ \\
\hline 13 & $(2,418)$ & 4,327 & 62,000 & 1,060 & 446,374 & 100,475 \\
\hline 14 & $(2,418)$ & 4,327 & 62,000 & 1,060 & 446,374 & 259,250 \\
\hline 15 & $(2,418)$ & 4,327 & 62,000 & 1,060 & 446,374 & $2,024,425$ \\
\hline 16 & 140,659 & 5,711 & 64,400 & 1,060 & 443,504 & 100,475 \\
\hline 17 & 205,747 & 5,711 & 64,400 & 1,060 & 443,504 & 100,475 \\
\hline 18 & 140,659 & 5,711 & 64,400 & 1,060 & 443,504 & 259,250 \\
\hline 19 & 205,747 & 5,711 & 64,400 & 1,060 & 443,504 & 259,250 \\
\hline
\end{tabular}

(a) Public Works Center San Diego 


\section{Acknowledgments}

The authors would like to thank Bob Miner, Naval Facilities Engineering Command Southwest Division, and John Thomas and Norman Groth, Navy Public Works Center San Diego, for providing information regarding the cogeneration system and for supporting this analysis.

Thanks also go to Robert Hoshide, Rockwell International, Energy Technology Engineering Center, Canoga Park, California, for his efforts in analyzing the condition of the existing facility.

Appreciation is extended to the following Pacific Northwest Laboratory staff whose efforts supported the study: Daryl Brown and Keith Daellenbach for cost estimates and life-cycle costing analysis, Steve Shankle and Donna Stucky for emissions and related analysis, Kate McMordie for field support and technical liaison, Sriram Somasundaram for technical peer review, and Cathy Anderson for final editing. 


\section{Contents}

Preface $\ldots \ldots \ldots \ldots \ldots \ldots \ldots \ldots \ldots \ldots \ldots \ldots \ldots \ldots \ldots \ldots \ldots$ iii

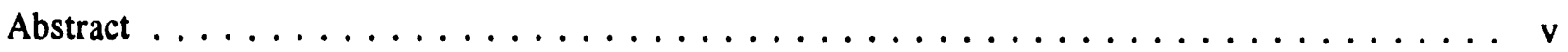

Executive Summary $\ldots \ldots \ldots \ldots \ldots \ldots \ldots \ldots \ldots \ldots \ldots \ldots \ldots$

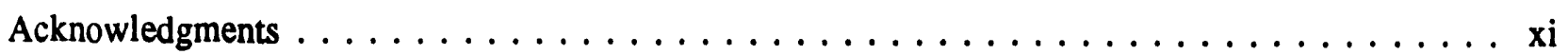

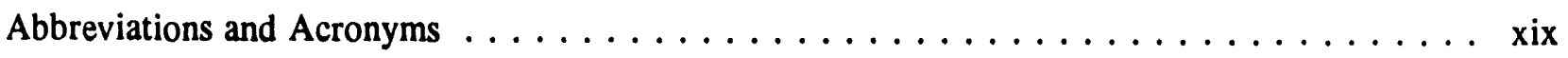

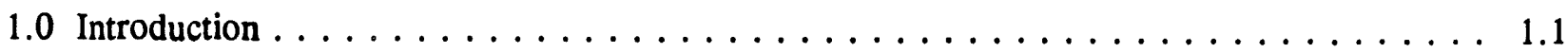

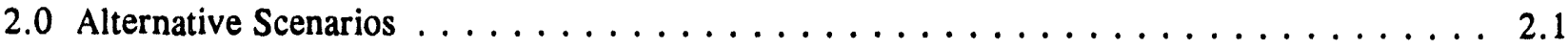

2.1 Scenario 1: Operate Plant Continuously $\ldots \ldots \ldots \ldots \ldots \ldots \ldots$

2.2 Scenario 2: Operate On-Peak and Semi-Peak Periods $\ldots \ldots \ldots \ldots \ldots \ldots \ldots$

2.3 Scenario 3: Operate On-Peak Period $\ldots \ldots \ldots \ldots \ldots \ldots \ldots \ldots \ldots \ldots \ldots \ldots \ldots$

2.4 Scenario 4: Repair Engines and Operate Continuously . . . . . . . . . . . 2.6

2.5 Scenario 5: Repair Engines and Operate On-Peak and Semi-Peak Periods . . . . . 2.6

2.6 Scenario 6: Repair Engines and Operate On-Peak Period $\ldots \ldots \ldots \ldots \ldots$

2.7 Scenario 7: Replace Engines and Operate Continuously $\ldots \ldots \ldots \ldots$

2.8 Scenario 8: Replace Engines and Operate On-Peak and Semi-Peak Periods $\ldots \ldots$. . 2.9

2.9 Scenario 9: Replace Engines and Operate On-Peak Period . . . . . . . . . . . . . 2.10

2.10 Scenario 10: Install Gas Turbines and Operate Continuously $\ldots \ldots \ldots \ldots \ldots$

2.11 Scenario 11: Install Gas Turbines and Operate On-Peak and Semi-Peak Periods . . . . . . . . . . . . . . . . . . . . 2.12

2.12 Scenario 12: Install Gas Turbines and Operate On-Peak Period $\ldots \ldots \ldots \ldots$

2.13 Scenario 13: Convert Plant to Emergency-Generator Status for Electrical and Thermal Energy $\ldots \ldots \ldots \ldots \ldots \ldots \ldots \ldots \ldots \ldots \ldots \ldots \ldots$

2.14 Scenario 14: Convert Plant to Emergency-Generator Status and Install Backup Boiler 
2.15 Scenario 15: Replace Plant with Emergency Generators and Backup Boiler

2.16 Scenario 16: Utilize SDG\&E Interruptible Schedule I-3, Rate D, with Scenario 13

2.17 Scenario 17: Utilize SDG\&E Interruptible Schedule I-3, Rate A, with Scenario 13

2.18 Scenario 18: Utilize SDG\&E Interruptible Schedule I-3, Rate D, with Scenario 14

2.19 Scenario 19: Utilize SDG\&E Interruptible Schedule I-3, Rate A, with Scenario 14

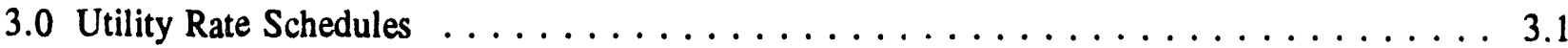

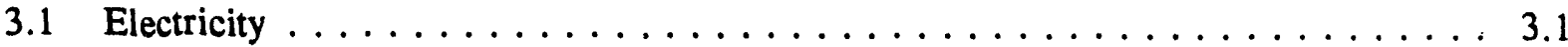

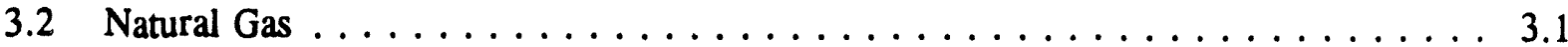

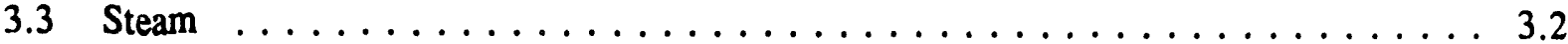

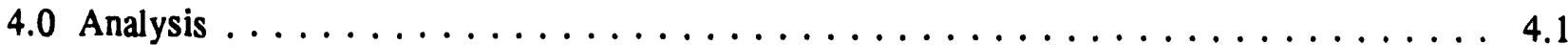

4.1 Cogeneration Operating Strategy $\ldots \ldots \ldots \ldots \ldots \ldots \ldots \ldots \ldots \ldots \ldots \ldots$

4.1 .1 Base Loading $\ldots \ldots \ldots \ldots \ldots \ldots \ldots \ldots \ldots \ldots \ldots \ldots$

4.1 .2 Electrical Load Following $\ldots \ldots \ldots \ldots \ldots \ldots \ldots \ldots \ldots \ldots$

4.1.3 Thermal Load Following $\ldots \ldots \ldots \ldots \ldots \ldots \ldots \ldots . \ldots \ldots$

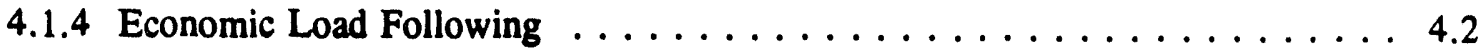

4.1.5 Marginal Energy Cost Analysis and Selection of Optimal Load
Operating Strategy $\ldots \ldots \ldots \ldots \ldots \ldots \ldots \ldots \ldots . \ldots \ldots \ldots$

4.2 Determining the Thermal Load of the NCTS Facility $\ldots \ldots \ldots \ldots \ldots \ldots$

4.2.1 Present Thermal Load $\ldots \ldots \ldots \ldots \ldots \ldots \ldots \ldots \ldots \ldots \ldots \ldots \ldots$

4.2.2 Growth of Thermal Load $\ldots \ldots \ldots \ldots \ldots \ldots \ldots \ldots \ldots \ldots$

4.3 Engineering and Economic Analysis $\ldots \ldots \ldots \ldots \ldots \ldots \ldots \ldots$

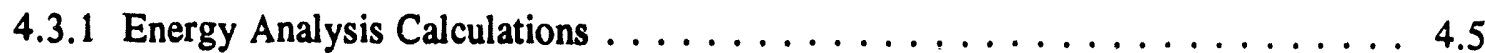


4.3.2 Operations and Maintenance Costs $\ldots \ldots \ldots \ldots \ldots \ldots$

4.3.3 Emissions and Related Costs $\ldots \ldots \ldots \ldots \ldots \ldots \ldots \ldots \ldots$. . . . . . . . . 41

4.3.4 Implementation Costs $\ldots \ldots \ldots \ldots \ldots \ldots \ldots \ldots \ldots \ldots \ldots$

4.3.5 Life-Cycle Cost Analysis $\ldots \ldots \ldots \ldots \ldots \ldots \ldots \ldots \ldots$

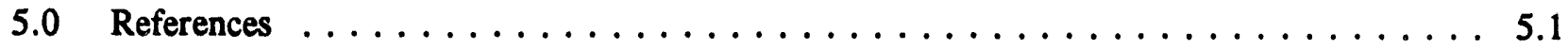

Appendix A - Public Works Center Meter Utility Reports for 1992 . . . . . . . . . . . . . A.1

Appendix B - Natural-Gas Unit Cost Calculations for $1992 \ldots \ldots \ldots \ldots \ldots$. . . . . . . . B.1

Appendix C - Public Works Center Federal Energy Regulatory Commission Calculations

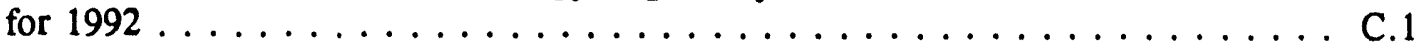

Appendix D - Marginal Energy Cost Calculations - Cogen Gas Rate . . . . . . . . . . D.1

Appendix E - Marginal Energy Cost Calculations - Non-Cogen Gas Rate . . . . . . . . . . . . E.1

Appendix F - Thermal Energy Analyses for Scenarios 1 Through $12 \ldots \ldots \ldots \ldots$

Appendix G - Energy Analyses for Scenarios 1 Through $12 \ldots \ldots \ldots \ldots$

Appendix H - Permit to Operate $\ldots \ldots \ldots \ldots \ldots \ldots \ldots \ldots \ldots \ldots \ldots \ldots \ldots \ldots$

Appendix I - Energy Technology Engineering Center Report $\ldots \ldots \ldots \ldots \ldots \ldots$ 


\section{Tables}

S.1 Summary of Life-Cycle Cost Analysis in 1995 Dollars . . . . . . . . . . . . . . viii

S.2 Summary of Major Cost Components in 1993 Dollars . . . . . . . . . . . . . . ix

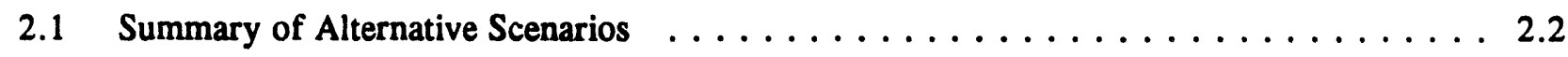

3.1 Schedule A6-TOU Transmission Rate $\ldots \ldots \ldots \ldots \ldots \ldots \ldots \ldots \ldots \ldots$

3.2 Schedule I-3 Interruptible Rate Options $\ldots \ldots \ldots \ldots \ldots \ldots \ldots \ldots \ldots \ldots$

3.3 Average Costs of Natural Gas for $1992 \ldots \ldots \ldots \ldots \ldots \ldots \ldots \ldots$

4.1 Thermal Energy Requirements for Cooling $\ldots \ldots \ldots \ldots \ldots \ldots \ldots \ldots$

4.2 Energy-Use Intensities for Domestic Hot Water $\ldots \ldots \ldots \ldots \ldots \ldots$

4.3 Summary of Energy and Energy Cost Information - NCTS Facility Under

4.4 Summary of Operations and Maintenance Costs $\ldots \ldots \ldots \ldots \ldots$

4.51991 Annual Emissions Per Engine $\ldots \ldots \ldots \ldots \ldots \ldots \ldots \ldots \ldots \ldots$

4.6 Potentially Availabie Emissions Credits $\ldots \ldots \ldots \ldots \ldots \ldots \ldots \ldots$

4.7 Estimated Value of Emission Reduction Credits $\ldots \ldots \ldots \ldots \ldots \ldots$

$4.8 \quad$ Value of Emissions Permits $\ldots \ldots \ldots \ldots \ldots \ldots \ldots \ldots \ldots$

4.9 Value of Renewal Fee and Emissions Permits for the Life-Cycle Cost Analysis . . . . . 4.16

4.10 Summary of Implementation Costs $\ldots \ldots \ldots \ldots \ldots \ldots \ldots$

4.11 Summary of Life-Cycle Cost Analysis in 1995 Dollars . . . . . . . . . . . . . 4.20 


\section{Abbreviations and Acronyms}

$\begin{array}{ll}\text { AEI } & \text { Applied Energy Incorporated } \\ \text { Btu } & \text { British thermal unit } \\ \text { CEC } & \text { California Energy Commission } \\ \text { CGA } & \text { cogeneration gas allowance } \\ \text { CO } & \text { carbon monoxide } \\ \text { DHW } & \text { domestic hot water } \\ \text { DoD } & \text { U.S. Department of Defense } \\ \text { DOE } & \text { U.S. Department of Energy } \\ \text { ETEC } & \text { Energy Technology Engineering Center } \\ \text { EUI } & \text { energy-use intensity } \\ \text { FEMP } & \text { Federal Energy Management Program } \\ \text { FERC } & \text { Federal Energy Regulatory Commission } \\ \text { FY } & \text { fiscal year } \\ \text { HHV } & \text { higher heating value } \\ \text { HVAC } & \text { heating, ventilating, and air conditioning } \\ \text { IHR } & \text { incremental heat rate } \\ \text { kW } & \text { kilowatt } \\ \text { kWh } & \text { kilowatt-hour } \\ \text { Mlb } & \text { thousand pounds } \\ \text { NASNI } & \text { Naval Air Station North Island } \\ \text { NCTS } & \text { Naval Computer and Telecommunications Station } \\ \text { NEESA } & \text { Navy Energy and Environmental Support Activity } \\ \text { NOx } & \text { oxides of nitrogen } \\ \text { O\&M } & \text { operations and maintenance } \\ \text { Pentech } & \text { Pentech Services, Inc. } \\ \text { PM } & \text { particulate matter } \\ \text { PNL } & \text { Pacific Northwest Laboratory } \\ \text { ppmv } & \text { parts per million by volume } \\ \text { PWCSD } & \text { Public Works Center San Diego } \\ \text { QF } & \text { qualified facility } \\ \text { ROC } & \text { reactive organic compounds } \\ \text { SDAPCD } & \text { San Diego Air Pollution Control District } \\ \text { SDG\&E } & \text { San Diego Gas \& Electric } \\ \text { SOx } & \text { oxides of sulfur } \\ \text { TOC } & \text { total organic compounds } \\ \text { UPS } & \text { uninterruptible power supply } \\ \text { USN } & \text { U.S. Navy } \\ & \end{array}$




\subsection{Introduction}

In 1986, a cogeneration plant was included in the original design and construction of the Naval Computer and Telecommunications Station (NCTS) facility, Building 1482, as part of Military Construction Project P-261 at the Naval Air Station North Island (NASNI) in San Diego, California (Gifford 1982). The plant is managed, owned, operated, and maintained by the U.S. Navy (USN) Public Works Center San Diego (PWCSD) under a Memorandum of Understanding with NCTS.

The plant consists of four $650-\mathrm{kW}$ Caterpillar engines with waste-heat recovery from the engine exhaust, oil, and jacket-cooling system. The engines are operated as rich burn, using natural gas with a propane backup fuel supply. Hot water from the waste heat recovery system is used in Building 1482 for comfort heating, domestic hot water (DHW), air-conditioning reheat, and comfort cooling. Three 400-ton Carrier absorption chillers are used for cooling. The engines have been derated to $600 \mathrm{~kW}$ by the San Diego Air Pollution Control District (SDAPCD). Each engine is equipped with two catalytic converters, installed in series, to reduce engine emissions to acceptable levels.

The current state of the cogeneration equipment is important to this analysis. The engines are currently operated using manual settings. The automated load controls for the system have been unreliable since the plant's construction and have been bypassed. In addition, the air-fuel controllers are approaching the end of their life and will soon need to be replaced. Reliability of the cogeneration engines is a concern, and downtime appears to be excessive.

Two engines are capable of supplying all, or a majority of, the absorber load for one chiller. If additional heat is required, it is provided by the NASNI steam loop. Three engines are capable of supplying the entire load of a single chiller with excess heat rejected to the cooling towers.

Since the plant was brought on line, a new long-term steam contract has been signed with Applied Energy Incorporated (AEI), which operates several cogeneration sites for the USN at San Diego and provides steam to the NASNI steam loop. The steam contract provides for a minimum steam purchase of 73,000 Mlb of steam per month by the USN. This is well above the maximum demand encountered in the 3 years the contract has been in place. Credit is applied to the steam bill for condensate returned and for electricity generated by AEI with excess steam. In addition, the USN has upgraded its electric distribution system to receive power from San Diego Gas \& Electric (SDG\&E) at $69 \mathrm{kV}$, allowing the USN to purchase power under a reduced-transmission rate schedule.

Currently, Building 1482 is not fully loaded because of the continuing miniaturization of computers. As a result, full load is not being placed on the electrical and thermal systems at the site. On the other hand, the ongoing consolidation of USN commands is causing a transition of additional functions to NCTS. As a result, additional demands will be placed on the building's electrical and thermal systems. 
Continuous cooling and electric power must be provided to the NCTS facility. Currently, backup thermal energy is provided by the NASNI steam distribution loop, and backup electric power is provided by the NASNI electric distribution grid. Three $750-\mathrm{kW}$ uninterruptible power supplies (UPS) are capable of providing power for 15 minutes to support the NCTS during an emergency power interruption.

A study of the cost-effectiveness of continued plant operation was performed by the Navy Energy and Environmental Support Activity (NEESA) in 1991 (Zavala and Heller 1991). That study concluded that it is feasible for the plant to operate only in a peak-shaving mode but did not make recommendations for additional backup thermal and electric power.

The USN commissioned Pacific Northwest Laboratory (PNL), in support of the U.S. Department of Energy (DOE) Federal Energy Management Program (FEMP), to determine the most costeffective approach to the operation of the cogeneration station with continuous requirements for backup electric and thermal sources. The goal is to minimize the life-cycle costs to the USN, either by optimizing the operation of the cogeneration facility or by shutting it down. This study evaluates 19 alternative operating scenarios for the cogeneration facility, ranging from continued operation to plant shutdown. The objective of this project is to minimize life-cycle costs to the USN, including raw-energy (natural gas, electricity, and steam), labor, maintenance, and contract costs. Included in the total cost to the USN is the cost of providing reliable emergency backup of electric and thermal energy to une facility.

Nineteen alternative scenarios were analyzed by PNL to determine whether to continue operating the cogeneration facility or convert the plant to emergency-generator status. This analysis considered the existing and alternative prime movers, alternative operating schedules, and four operating load strategies. The analysis utilized the available information to determine utility consumption and cost, labor cost, and maintenance cost.

This report contains four major sections and several appendices. In Section 2.0, the alternative scenarios are presented. Section 3.0 presents the utility rate schedules and their associated energy cost information as they pertain to this analysis. The analysis of the alternative scenarios and supporting information are described in Section 4.0. The appendices contain information and calculations used to analyze the alternative scenarios. Appendix A contains 1992 PWCSD meter utility reports. Natural-gas unit cost calculations for 1992 are shown in Appendix B. Appendix C contains PWCSD Federal Energy Regulatory Commission (FERC) calculations for 1992. Marginal energy cost calculations for cogen gas rates are presented in Appendix D, and non-cogen gas rates are presented in Appendix E. Appendix F contains thermal energy analyses for Scenarios 1 through 12. Appendix G contains energy analyses for Scenarios 1 through 12. Appendix $\mathrm{H}$ contains a Permit to Operate, and Appendix I contains an energy technology engineering center report for the NCTS at NASNI. 


\subsection{Alternative Scenarios}

Nineteen alternative scenarios have been analyzed to determine whether to continue operating the NCTS cogeneration plant or to convert the plant to emergency-generator status. These scenarios, introduced below and summarized in Table 2.1, are discussed in subsections that follow.

- Scenario 1: Operate plant continuously. The NCTS cogeneration facility continues its current operation, operating continuously. SDG\&E electric service is used for emergency power, and AEI steam service provides emergency backup thermal energy to the facility. This scenario represenis the existing system or base case.

- Scenario 2: Operate on-peak and semi-peak periods. The NCTS cogeneration plant continues its current operation, but only during the SDG\&E on-peak and semi-peak periods. The cogeneration facility functions as an emergency generator during the off-peak period, providing both electric and thermal energy backup.

- Scenario 3: Operate on-peak period. The NCTS cogeneration plant continues its current operation, but only during the SDG\&E on-peak period. The cogeneration facility functions as an emergency generator during the semi-peak and off-peak periods, providing both electric and thermal energy backup.

- Scenario 4: Repair engines and operate continuously. The NCTS cogeneration facility is upgraded to operate as it was originally intended and operates continuously. Operating procedures are modified to utilize more of the recoverable thermal energy. SDG\&E electric service is used for emergency power, and AEI steam service provides emergency backup thermal energy to the facility.

- Scenario 5: Repair engines and operate on-peak and semi-peak periods. The NCTS cogeneration facility is upgraded to operate as it was originally intended and operates during the SDG\&E on-peak and semi-peak periods. Operating procedures are modified to utilize more of the recoverable thermal energy. The cogeneration facility functions as an smergency generator during the off-peak period, providing both electric and thermal energy backup.

- Scenario 6: Repair engines and operate on-peak period. The NCTS cogeneration facility is upgraded to operate as it was originally intended and operates during the SDG\&E on-peak period. Operating procedures are modified to utilize more of the recoverable thermal energy. The cogeneration facility functions as an emergency generator during the semi-peak and off-peak periods, providing both electric and thermal energy backup.

- Scenario 7: Replace engines and operate continuously. The cogeneration engines and controls are replaced with new reciprocating engines with a higher electrical efficiency. Operating procedures are modified to utilize more of the recoverable thermal energy. The cogeneration facility operates continuously. SDG\&E electric service is used for emergency power, and AEI steam service provides emergency backup thermal energy to the facility. 
Table 2.1. Summary of Alternative Scenarios

\begin{tabular}{|c|c|c|c|c|c|c|c|}
\hline \multirow[b]{2}{*}{ Scenario } & \multirow[b]{2}{*}{ Description } & \multirow[b]{2}{*}{ Load (kW) } & \multicolumn{2}{|c|}{ Number of Engines } & \multicolumn{3}{|c|}{ Operatine Period } \\
\hline & & & Available & Openting & On-Peak & Semi-Peak & Off-Peak \\
\hline 1 & As-ls & 600 & 4 & 2 & $\mathbf{x}$ & $\mathbf{x}$ & $\mathbf{x}$ \\
\hline 2 & As-Is & 600 & 4 & 2 & $\mathbf{x}$ & $\mathbf{X}$ & \\
\hline 3 & As-ls & 600 & 4 & 2 & $\mathbf{x}$ & & \\
\hline 4 & Repaired & 600 & 4 & 4 & $\mathbf{x}$ & $\mathbf{x}$ & $\mathbf{x}$ \\
\hline 5 & Repuired & 600 & 4 & 4 & $\mathbf{x}$ & $\mathbf{x}$ & \\
\hline 6 & Repaired & 600 & 4 & 4 & $\mathbf{x}$ & & \\
\hline 7 & New Recips & 610 & 4 & 4 & $\mathbf{x}$ & $\mathbf{x}$ & $\mathbf{x}$ \\
\hline 8 & New Recips & 610 & 4 & 4 & $\mathbf{x}$ & $\mathbf{x}$ & \\
\hline 9 & New Recips & 610 & 4 & 4 & $\mathbf{x}$ & & \\
\hline 10 & Gas Turbines & 1540 & 2 & 2 & $\mathbf{x}$ & $\mathbf{x}$ & $\mathbf{x}$ \\
\hline 11 & Gas Turbines & 1540 & 2 & 2 & $\mathbf{x}$ & $\mathrm{x}$ & \\
\hline 12 & Gas Turbines & 1540 & 2 & 2 & $\mathbf{x}$ & & \\
\hline 13 & Emerg. Cogen & 600 & 4 & 4 & & & \\
\hline 14 & Emerg. Gen. & 600 & 4 & 4 & & & \\
\hline 15 & New Gen. & 610 & 4 & 4 & & & \\
\hline 16 & SDG\&E Inter. & 600 & 4 & 4 & Sam & as $13 w / 1-3$ & ate $D$ \\
\hline 17 & SDG\&E Inter. & 600 & 4 & 4 & Sam & as $13 \mathrm{w} / \mathrm{I}-3$ & ate $\mathrm{A}$ \\
\hline 18 & SDG\&E Inter. & 600 & 4 & 4 & & as $14 \mathrm{w} / 1-3$ & ate D \\
\hline 19 & SDG\&E Inter. & 600 & 4 & 4 & & as $14 w / I-3$ & ate $\mathrm{A}$ \\
\hline
\end{tabular}

- Scenario 8: Replace engines and operate on-peak and semi-peak periods. The cogeneration engines and controls are replaced with new reciprocating engines with a higher electrical efficiency. Operating procedures are modified to utilize more of the recoverable thermal energy. The cogeneration facility operates during the SDG\&E on-peak and semi-peak periods. The cogeneration facility functions as an emergency generator during the off-peak period, providing both electric and thermal energy backup.

- Scenario 9: Replace engines and operate on-peak period. The cogeneration engines and controls are replaced with new reciprocating engines with a higher electrical efficiency. Operating procedures are modified to utilize more of the recoverable thermal energy. The cogeneration facility operates during the SDG\&E on-peak period. The cogeneration facility functions as an emergency generator during the semi-peak and off-peak periods, providing both electric and thermal energy backup.

- Scenario 10: Install gas turbines and operate continuously. The cogeneration engines and controls are replaced with new gas turbines. Operating procedures are modified to utilize more of the recoverable thermal energy. The cogeneration facility operates continuously. SDG\&E 
electric service is used for emergency power, and AEI steam service provides emergency backup thermal energy to the facility.

- Scenario 11: Install gas turbines and operate on-peak and semi-peak periods. The cogeneration engines and controls are replaced with new gas turbines. Operating procedures are modified to utilize more of the recoverable thermal energy. The cogeneration facility operates during the SDG\&E on-peak and semi-peak periods. The cogeneration facility functions as an emergency generator during the off-peak period, providing both electric and thermal energy backup.

- Scenario 12: Install gas turbines and operate on-peak period. The cogeneration engines and controls are replaced with new gas turbines with a higher electrical efficiency. Operating procedures are modified to utilize more of the recoverable thermal energy. The cogeneration facility operates during the SDG\&E on-peak period. The cogeneration facility functions, as an emergency generator during the semi-peak and off-peak periods, providing both electric and thermal energy backup.

- Scenario 13: Convert plant to emergency-generator status for electrical and thermal energy. The NCTS cogeneration facility is converted to an emergency-generator facility, providing both emergency electric power and emergency thermal energy. SDG\&E provides the facility with primary electric energy, and AEI provides primary thermal energy.

- Scenario 14: Convert plant to emergency-generator status and install backup boiler. The NCTS cogeneration facility is converted to an emergency-generator facility, providing emergency electric power. A boiler is installed to provide emergency thermal energy. SDG\&E provides the facility with primary electric energy, and AEI provides primary thermal energy.

- Scenario 15: Replace plant with emergency generators and backup boiler. The NCTS cogeneration facility is converted to an emergency-generator facility. New emergency generators are installed to provide emergency electric power. A boiler is installed to provide emergency thermal energy. SDG\&E provides the facility with primary electric energy, and AEI provides primary thermal energy.

- Scenario 16: Utilize SDG\&E Interruptible Schedule I-3, Rate D with Scenario 13. This scenario is the same as Scenario 13. In addition, PWCSD incorporates the SDG\&E Interruptible Schedule 1-3, Rate D, using the NCTS emergency-generator facility to shed demand at the request of SDG\&E during its system peaks.

- Scenario 17: Utilize SDG\&E Interruptible Schedule I-3, Rate A with Scenario 13. This scenario is the same as Scenario 13. In addition, PWCSD incorporates the SDG\&E Interruptible Schedule I-3, Rate A, using the NCTS emergency-generator facility to shed demand at the request of SDG\&E during its system peaks.

- Scenario 18: Utilize SDG\&E Interruptible Schedule I-3, Rate D with Scenario 14. This scenario is the same as Scenario 14. In addition, PWCSD incorporates the SDG\&E Interruptible Schedule I-3, Rate D, using the NCTS emergency-generator facility to shed demand at the request of SDG\&E during its system peaks. 
- Scenario 19: Utilize SDG\&E Interruptible Schedule I-3, Rate A with Scenario 14. This scenario is the same as Scenario 14. In addition, PWCSD incorporates the SDG\&E Interruptible Schedule I-3, Rate A, using the NCTS emergency-generator facility to shed demand at the request of SDG\&E during its system peaks.

\subsection{Scenario 1: Operate Plant Continuously}

Under this scenario, the NCTS cogeneration facility continues its current operation, operating continuously. The cogeneration facility consists of four Caterpillar model G399 internal-combustion reciprocating engines rated at $650-\mathrm{kW}$ maximum output. The facility currently operates two engines manually, attempting to maintain engine loading at approximately $600-\mathrm{kW}$ output. Review of the operating records indicates that the engines operate at an average load of $570 \mathrm{~kW}$, assuming that two of the four engines are operating continuously (see Appendix A). Assuming that two engines are continuously on-line corresfonds to a $94 \%$ load utilization factor $(94 \%$ of $600 \mathrm{~kW})$. The engine generators specified have a tull-load $(650 \mathrm{~kW})$ heat rate of $12,011 \mathrm{Btu} / \mathrm{kWh}$ based on the higher heating value (HHV) of the fuel. This corresponds to an electrical efficiency of $28.4 \%$ at full load.

The facility is continuously staffed. Staffing consists of one maintenance mechanic (WG-10) on the day shift, five watch standers (WG-11) on rctating shifts, and one foreman on the day shift. Preventive maintenance is provided by the subcontractor, Pentech Services, Inc. (Pentech).

Waste heat recovered from the engines is used to meet thermal energy requirements of the NCTS facility, consisting of DHW, building heat, air-conditioning reheat, and building cooling requirements through absorption chillers. The NCTS facility has three 400 -ton absorption chillers. Only one chiller is required to meet the facility's peak load. To distribute operating hours, the operating chiller is rotated among the three available chillers. Two engines are capable of providing more than enough thermal energy to meet the facility requirements. Thermal energy recovered from the cogeneration system, but not utilized, is rejected through cooling towers.

Emergency power is provided through interconnection to the SDG\&E electric grid. An UPS provides 15 minutes of backup power during an interruption. Steam is available from AEI to provide backup of thermal energy requirements for the NCTS facility. A steam heat exchanger is used to provide hot water to the various thermal systems. Only one of the three chillers is capable of being operated with the steam-supplied heat. This chiller has always consumed some steam energy when in operation. Analysis of the steam and thermal energy logs indicates that the NCTS facility meets approximately $30 \%$ of the thermal energy requirements with steam energy, even though thermal energy recovered from the cogeneration system is available.

Fuel consumption, electricity generation, and thermal energy utilization, obtained from PWCSD meters, are provided in Appendix A. The utility rate schedules and assumptions made in estimating operating costs are discussed in Section 3.0.

The existing engines have a total estimated life of 120,000 run-hours or 25 years (maximum). As of October 1992, the engines have operated an average of $20,700 \mathrm{~h}$ each. At the proposed operating schedule (i.e., 4,380 h/engine-yr) beginning in 1995, the existing engines will need to be 
replaced in 2015. At the end of the life-cycle cost analysis period, it is estimated that the replacement engines will have approximately $81 \%$ of their life remaining. The heat recovery system, however, has a longer estimated life and will not need to be replaced within the life of this analysis.

\subsection{Scenario 2: Operate On-Peak and Semi-Peak Periods}

Under this scenario, the cogeneration facility continues to operate two engines, as in Scenario 1, during the SDG\&E on-peak and semi-peak periods. The cogeneration facility does not operate during the off-peak period. During the off-peak period, electric power is supplied by SDG\&E and thermal energy requirements are supplied by AĖI steam.

In case of interruption in either the electric power or steam supply during the off-peak period, the cogeneration system is manually restarted. Because it is believed that the existing controls are not capable of starting the plant automatically, continuous staffing of the facility is required, as in Scenario 1, even during shutdown. Staffing consists of one maintenance mechanic (WG-10) on the day shift, five watch standers (WG-11) on rotating shifts, and one foreman on the day shift. Preventive maintenance is provided by the subcontractor, Pentech.

The existing engines have a total estimated life of 120,000 run-hours or 25 years (maximum). As of October 1992, the engines have operated an average of $20,700 \mathrm{~h}$ each. At the proposed operating schedule $(2,040 \mathrm{~h} /$ engine-yr) beginning in 1995, the existing engines will not need to be replaced within the life-cycle cost analysis period. The economic value of the engines at the end of the life-cycle cost analysis period is assumed to be negligible because of the age of the engines.

\subsection{Scenario 3: Operate On-Peak Period}

Under this scenario, the cogeneration facility continues to operate two engines, as in Scenario 1, during the SDG\&E on-peak period. The cogeneration facility does not operate during the semi-peak and off-peak periods. During the semi-peak and off-peak periods, electric power is supplied by SDG\&E and thermal energy requirements are supplied by AEI steam.

In case of interruption in either the electric power or steam supply during the semi-peak and offpeak periods, the cogeneration system is manually restarted. Because it is believed that the existing controls are not capable of starting the plant automatically, continuous staffing of the facility is required, as in Scenario 1, even during shutdown. Staffing consists of one maintenance mechanic (WG-10) on the day shift, five watch standers (WG-11) on rotating shifts, and one foreman on the day shift. Preventive maintenance is provided by the subcontractor, Pentech.

The existing engines have a total estimated life of 120,000 run-hours or 25 years (maximum). As of October 1992, the engines have operated an average of $20,700 \mathrm{~h}$ each. At the proposed operating schedule ( $594.5 \mathrm{~h} /$ engine $\cdot y r)$ beginning in 1995 , the existing engines will not need to be replaced within the life-cycle cost analysis period. The economic value of the engines at the end of the life-cycle cost analysis period is assumed to be negligible because of the age of the equipment. 


\subsection{Scenario 4: Repair Engines and Operate Continuously}

Under this scenario, the existing cogeneration facility is upgraded to operate as it was originally intended and operates continuously. This upgrade includes new load-sharing and speed controls, new air fuel ratio controllers, and additional repairs as outlined in Appendix $\mathbf{I}$.

The cogeneration facility continuously operates all four engines at the full derated load of $600 \mathrm{~kW}$. Scheduled downtime is assumed to be approximately 3\%. All thermal energy required by the NCTS facility is recovered from the cogeneration system. No steam from the AEI steam system is consumed to meet the normal thermal energy load, except in emergency operating conditions. Excess thermal energy recovered from the cogeneration system is rejected though the existing cooling towers.

The existing engines have a total estimated life of 120,000 run-hours or 25 years (maximum). As of October 1992, the engines have operated an average of $20,700 \mathrm{~h}$ each. At the proposed operating schedule (8,500 h/engine-yr) beginning in 1995, the existing engines will need to be replaced in 2005 , and again in 2019. At the end of the life-cycle cost analysis period, it is estimated that the replacement engines will have approximately $89 \%$ of their life remaining. The heat recovery system, however, has a longer estimated life and will not need to be replaced within the life of this analysis.

The facility is continuously staffed as in Scenario 1, consisting of one maintenance mechanic (WG-10) on the day shift, five watch standers (WG-11) on rotating shifts, and one foreman on the day shift. Preventive maintenance is still provided by the subcontractor, Pentech.

Emergency electric power is provided by the SDG\&E electrical grid. Emergency thermal energy is provided by the AEI steam system.

\subsection{Scenario 5: Repair Engines and Operate On-Peak and Semi-Peak Periods}

Under this scenario, the existing cogeneration facility is upgraded to operate as it was originally intended as in Scenario 4. This upgrade includes new load-sharing and speed controls, new air-tofuel ratio controllers, and additional repairs as outlined in Appendix I. The new controls are capable of reliably starting the engines automatically, controlling the air-to-fuel ratio, and controlling the engine loading.

The cogeneration facility operates all four engines at the full derated load of $600 \mathrm{~kW}$ during the SDG\&E on-peak and semi-peak periods. Scheduled downtime is assumed to be approximately $3 \%$. During the off-peak period, electric power is supplied by SDG\&E and thermal energy requirements are supplied by AEI steam.

The existing engines have a total estimated life of 120,000 run-hours or 25 years (maximum). As of October 1992, the engines have operated an average of $20,700 \mathrm{~h}$ each. At the proposed operating schedule $(3,959 \mathrm{~h} /$ engine-yr) beginning in 1995, the existing engines will need to be replaced in 2017. At the end of the life-cycle cost analysis period, it is estimated that the replacement 
engines will have approximately $87 \%$ of their life remaining. The heat recovery system, however, has a longer estimated life and will not need to be replaced within the life of this analysis.

All thermal energy required by the NCTS facility is recovered from the cogeneration system when it is in operation. No steam from the AEI steam system is consumed to meet the thermal energy load while the cogeneration system is operating. Excess thermal energy recovered from the cogeneration system is rejected through the existing cooling towers.

The cogeneration plant is staffed during the on-peak and semi-peak periods. It is not staffed during the off-peak period unless a power interruption occurs. Because the SDG\&E operating periods do not correspond exactly to PWCSD work shifts, it is assumed that PWCSD staff can be rotated to other PWCSD job assignments when the cogeneration system is not in operation. This assumption is further detailed in Section 4.3.2. Staffing consists of approximately one foreman on the day shift, one maintenance mechanic (WG-10) on the day shift, and one watch stander (WG-11) present onehalf hour before scheduled operation until one-half hour after scheduled shutdown. Preventive maintenance is still provided by the subcontractor, Pentech.

Part of the responsibility of the cogeneration staff is to monitor and operate the central chilledwater facility. Because the plant will not be staffed continuously, the chilled-water system will be equipped with new automated valves and controls to respond to equipment failures. Should a chiller, cooling tower, or pump fail, the new control system will shut down the failed component and automatically start another. The new system will be an expansion to the existing Johnson Controls system that currently monitors and controls much of the central heating, ventilating, and air-conditioning (HVAC) system.

While the cogeneration system is running, emergency electric power is provided by the SDG\&E electric grid and emergency thermal energy is provided by the AEI steam system. During the offpeak period when the cogeneration system is not running, the system acts as an emergency-generator facility. The cogeneration system is started automatically if an interruption occurs in the electric power or stean supply.

\subsection{Scenario 6: Repair Engines and Operate On-Peak Period}

Under this scenario, the existing cogeneration facility is upgraded to operate as it was originally intended as in Scenario 4. This upgrade includes new load-sharing and speed controls, new air fuel

ratio controllers, and additional repairs as outlined in Appendix I. The new controls are capable of reliably starting the engines automatically, controlling the air-to-fuel ratio, and controlling the engine loading.

The cogeneration facility operates all four engines at the full derated load of $600 \mathrm{~kW}$ during the SDG\&E on-peak period. Scheduled downtime is assumed to be approximately $3 \%$. During the semipeak and off-peak periods, electric power is supplied by SDG\&E and thermal energy requirements are supplied by AEI steam. 
The existing engines have a total estimated life of 120,000 run-hours or 25 years (maximum). As of October 1992, the engines have operated an average of $20,700 \mathrm{~h}$ each. At the proposed uperating schedule (1,154 h/engine $y r)$ beginning in 1995, the existing engines will not need to be replaced within the life-cycle cost analysis period. The economic value of the engines at the end of the life-cycle cost analysis period is assumed to be negligible because of the age of the engines.

All thermal energy required by the NCTS facility is recovered from the cogeneration system when it is in operation. No steam from the AEI steam system is consumed to meet the thermal energy load while the cogeneration system is operating. Excess thermal energy recovered from the cogeneration system is rejected through the existing cooling towers.

The cogeneration plant is staffed during the on-peak period. It is not staffed during the semipeak and off-peak periods unless a power interruption occurs. Because the SDG\&E operating periods do not correspond exactly to PWCSD work shifts, it is assumed that PWCSD staff can be rotated to other PWCSD job assignments when the cogeneration system is not in operation. This assumption is further detailed in Section 4.3.2. Staffing consists of approximately one foreman, one maintenance mechanic (WG-10), and one watch stander (WG-11) present one-half hour before scheduled operation until one-half hour after scheduled operation. Preventive maintenance is still provided by the subcontractor, Pentech.

Part of the responsibility of the cogeneration staff is to monitor and operate the central chilledwater facility. Because the plant will not be staffed continuously, the chilled-water system will be equipped with new automated valves and controls to respond to equipment failures. Should a chiller, cooling tower, or pump fail, the new control system will shut down the failed component and automatically start another. The new system will be an expansion to the existing Johnson Control system that currently monitors and controls much of the central HVAC system.

While the cogeneration system is running, emergency electric power is provided by the SDG\&E electric grid and emergency thermal energy is provided by the AEI steam system. During the semipeak and off-peak periods when the cogeneration system is not running, the system acts as an emergency-generator facility. The cogeneration system is started automatically if an interruption occurs in the electric power or steam supply.

\subsection{Scenario 7: Replace Engines and Operate Continuously}

Under this scenario, the engine generators are replaced with four new engine generators with approximately the same output as the existing system. It is estimated that the existing engines have a salvage value of $\$ 50,000$ each (see Appendix I); however, it is assumed that the salvage value will cover the cost of their removal, sale, and transfer. Because the value of the generated electric energy is the driving economic factor (see Section 4.1.5), the new generators specified for this analysis have a heat rate of $10,500 \mathrm{Btu} / \mathrm{kWh}$ based on the HHV of the fuel. This corresponds to an electrical efficiency of $32.5 \%$ at full load, which is a higher electrical efficiency than the existing engines. The engines selected for this analysis are rated at $610 \mathrm{~kW}$ (Hay 1988). The new engines are equipped with completely new control systems. The new controls are capable of reliably starting the engines automatically, controlling the air-to-fuel ratio, and controlling the engine loading. 
The existing heat recovery system can be adapted to the new engines. With a higher electrical efficiency, less energy is recoverable as useful thermal energy. It is estimated that $38 \%$ of the input energy can be recovered as useful thermal energy, still providing more than enough energy to meet the thermal energy requirements of the facility.

The cogeneration facility continuously operates all four engines at the full-load rating of $610 \mathrm{~kW}$. Scheduled downtime is assumed to be approximately 3\%. The cogeneration facility is staffed as outlined in Scenario 1. All thermal energy required by the NCTS facility is recovered from the cogeneration system.

The new engines have a total estimated life of 120,000 run-hours or 25 years (maximum). At the proposed operating schedule $(8,500 \mathrm{~h} /$ engine-yr) beginning in 1995 , the new engines will need to be replaced in 2009. At the end of the life-cycle cost analysis period, it is estimated that the replacement engines will have approximately $18 \%$ of their life remaining. The heat recovery system, however, has a longer estimated life and will not need to be replaced within the life of this analysis.

Emergency electric power is provided by the SDG\&E electric grid. Emergency thermal energy is provided by the AEI steam system.

\subsection{Scenario 8: Replace Engines and Operate On-Peak and Semi-Peak Periods}

Under this scenario, the engine generators are replaced with four new engine generators with approximately the same output as the existing system as in Scenario 7. Similarly, it is estimated that the existing engines have a salvage value of $\$ 50,000$ each (see Appendix I); however, it is assumed that the salvage value will cover the cost of their removal, sale, and transfer. Because the value of the generated electric energy is the driving economic factor (see Section 4.1.5), the new generators specified have a heat rate of $10,500 \mathrm{Btu} / \mathrm{kWh}$ based on the HHV of the fuel. This corresponds to an electrical efficiency of $32.5 \%$ at full load, which is a higher electrical efficiency than the existing engines. The engines selected for this analysis are rated at $610 \mathrm{~kW}$ (Hay 1988). The new cogeneration system is equipped with a completely new control system. The new controls are capable of reliably starting the engines automatically, controlling the air-to-fuel ratio, and controlling the engine loading.

The existing heat recovery system can be adapted to the new engines. However, with a higher electrical efficiency, less waste heat is available for recovery as useful thermal energy. It is estimated that $38 \%$ of the input energy can be recovered as useful thermal energy, still providing more than enough heat to meet the thermal energy requirements. All thermal energy required by the NCTS facility is recovered from the cogeneration system when it is operating.

The cogeneration facility operates all four engines at the full-load rating of $610 \mathrm{~kW}$ during the SDG\&E on-peak and semi-peak periods. Scheduled downtime is assumed to be approximately $3 \%$. During the off-peak period, electric power is supplied by SDG\&E and thermal energy requirements are supplied by AEI steam. The cogeneration facility is staffed as outlined in Scenario 5. 
Part of the responsibility of the jogeneration staff is to monitor and operate the central chilledwater facility. Because the plant will not be staffed continuously, the chilled-water system will be equipped with new automated valves and controls to respond to equipment failures. Should a chiller, cooling tower, or pump fail, the new control system will shut down the failed component and automatically start another. The new system will be an expansion to the existing Johnson Controls system that currently monitors and controls much of the central HVAC system.

The new engines have a total estimated life of 120,000 run-hours or 25 years (maximum). At the proposed operating schedule $(3,959 \mathrm{~h} /$ engine-yr) beginning in 1995 , the new engines will not need to be replaced in the life-cycle cost analysis period. The economic value of the engines at the end if the life-cycle cost analysis period is assumed to be negligible because of the age of the equipment. The heat recovery system, however, has a longer estimated life and will not need to be replaced within the life of this analysis.

While the cogeneration system is running, emergency electric power is provided by the SDG\&E electrical grid and emergency thermal energy is provided by the AEI steam system. During the offpeak period when the cogeneration system is not running, the system acts as an emergency-generator facility. In case of interruption in either the electric power or steam supply, the cogeneration system is started automatically.

\subsection{Scenario 9: Replace Engines and Operate On-Peak Period}

Under this scenario, the engine generators are replaced with four new engine generators with approximately the same output as the existing system as in Scenario 7. Similarly, it is estimated that the existing engines have a salvage value of $\$ 50,000$ each (see Appendix I); however, it is assumed that the salvage value will cover the cost of their removal, sale, and transfer. Because the value of the generated electric energy is the driving economic factor (see Section 4.1.5), the new generators specified have a heat rate of $10,500 \mathrm{Btu} / \mathrm{kWh}$ based on the HHV of the fuel. This corresponds to an electrical efficiency of $32.5 \%$ at full load, which is a higher electrical efficiency than the existing engines. The engines selected for this analysis are rated at $610 \mathrm{~kW}$. The new cogeneration system is equipped with a new control system. The new controls are capable of reliably starting the engines automatically, controlling the air-to-fuel ratio, and controlling the engine loading.

The existing heat recovery system can be adapted to the new engines. With a higher electrical efficiency, less energy is recoverable as useful thermal energy. It is estimated that $38 \%$ of the input energy can be recovered as useful thermal energy, still providing more than enough energy to meet the thermal energy requirements. All thermal energy required by the NCTS facility is recovered from the cogeneration system when it is operating.

The cogeneration facility operates all four engines at the full-load rating of $610 \mathrm{~kW}$ during the SDG\&E on-peak period. Scheduled downtime is assumed to be approximately 3\%. During the semipeak and off-peak periods, electric power is supplied by SDG\&E and thermal energy requirements are supplied by AEI steam. The cogeneration facility is staffed as outlined in Scenario 6 . 
Part of the responsibility of the cogeneration staff is to monitor and operate the central chilledwater facility. Because the plant will not be staffed continuously, the chilled-water system will be equipped with new automated valves and controls to respond to equipment failures. Should a chiller, cooling tower, or pump fail, the new control system will shut down the failed component and automatically start another. The new system will be an expansion to the existing Johnson Controls system that currently monitors and controls much of the central HVAC system.

The new engines have a total estimated life of 120,000 run-hours or 25 years (maximum). At the proposed operating schedule $(1,154 \mathrm{~h} /$ engine-yr) beginning in 1995, the new engines will not need to be replaced in the life-cycle cost analysis period. The economic value of the engines at the end of the life-cycle cost analysis period is assumed to be negligible because of the age of the equipment. The heat recovery system, however, has a longer estimated life and will not need to be replaced within the life of this analysis.

While the cogeneration system is running, emergency electric power is provided by the SDG\&E electrical grid and emergency thermal energy is provided by the AEI steam system. During the semipeak and off-peak periods when the cogeneration system is not running, the system acts as an emergency-generator facility. In case of interruption in either the electric power or steam supply, the cogeneration system is started automatically.

\subsection{Scenario 10: Install Gas Turbines and Operate Continuously}

Under this scenario, the existing engine generators are replaced with two new gas turbine generators with a total electric capacity similar to that of the existing system. The new generators specified have a heat rate of $14,620 \mathrm{Btu} / \mathrm{kWh}$ based on the HHV of the fuel. This corresponds to an electrical efficiency of $22.5 \%$ at full load. The turbines selected for this analysis are rated at $1,540 \mathrm{~kW}$ each (Hay 1988). The new turbines are equipped with a complete new control system. The new controls are capable of reliably starting the turbines automatically, controlling the air-to-fuel ratio, and controlling the turbine loading.

The gas turbines require a new heat recovery system. It is estimated that $45 \%$ of the input energy can be recovered as useful thermal energy, still providing more than enough energy to meet the thermal energy requirements of the facility.

The cogeneration facility continuously operates both turbines at the full-load rating of $1,540 \mathrm{~kW}$. Scheduled downtime is assumed to be approximately $3 \%$. The cogeneration facility is staffed as outlined in Scenario 1. Special training is provided to the staff on gas turbines. All thermal energy required by the NCTS facility is recovered from the cogeneration system.

The new gas turbines have a total estimated life of 180,000 run-hours or 30 years (maximum). At the proposed operating schedule $(8,500 \mathrm{~h}$ /engine-yr) beginning in 1995 , the new turbines will need to be replaced in 2016. At the end of the life-cycle cost analysis period, it is estimated that the replacement turbines will have approximately $78 \%$ of their life remaining. The heat recovery system, however, has a longer estimated life and will not need to be replaced within the life of this analysis. 
The salvage value of the existing reciprocating engines is estimated to be $\$ 50,000$ each (in 1993); however, it is assumed that this will cover the cost of their removal, sale, and transfer.

Emergency electric power is provided by the SDG\&E electric grid. Emergency thermal energy is provided by the AEI steam system.

\subsection{Scenario 11: Install Gas Turbines and Operate On-Peak and Semi- Peak Periods}

Under this scenario, the existing engine generators are replaced with two new gas turbine generators with a total electric capacity similar to that of the existing system as in Scenario 10 . The new generators specified have a heat rate of $14,620 \mathrm{Btu} / \mathrm{kWh}$ based on the HHV of the fuel, corresponding to an electrical efficiency of $22.5 \%$ at full load. The turbines selected for this analysis are rated at $1,540 \mathrm{~kW}$ each. The new turbines are equipped with a complete new control system. The new controls are capable of reliably starting the turbines automatically, controlling the air-to-fuel ratio, and controlling the turbine loading.

The gas turbines require a new heat recovery system. It is estimated that $45 \%$ of the input energy can be recovered as useful thermal energy, still providing more than enough energy to meet the thermal energy requirements.

The cogeneration facility operates both turbines at the full-load rating of $1,540 \mathrm{~kW}$ during the SDG\&E on-peak and semi-peak periods. Scheduled downtime is assumed to be approximately $3 \%$. During the off-peak period, electric power is supplied by SDG\&E and thermal energy requirements are supplied by AEI steam. The cogeneration facility is staffed as outlined in Scenario 5. Special training is provided to the staff on gas turbines.

Part of the responsibility of the cogeneration staff is to monitor and operate the central chilledwater facility. Because the plant will not be staffed continuously, the chilled-water system will be equipped with new automated valves and controls to respond to equipment failures. Should a chiller, cooling tower, or pump fail, the new control system will shut down the failed component and automatically start another. The new system will be an expansion to the existing Johnson Controls system that currently monitors and controls much of the central HVAC system.

The new gas turbines have a total estimated life of 180,000 run-hours or 30 years (maximum). At the proposed operating schedule (3,959 h/engine-yr) beginning in 1995, the new turbines will not need to be replaced in the life-cycle cost analysis period. At the end of the analysis period, it is estimated that the turbines will have approximately $17 \%$ of their economic life remaining because of the age of the turbines. The heat recovery system, however, has a longer estimated life and will not need to be replaced within the life of this analysis. The salvage value of the existing engines is estimated to be $\$ 50,000$ each (in 1993); however, it is assumed that this will cover the cost of their removal, sale, and transfer.

While the cogeneration system is running, emergency electric power is provided by the SDG\&E electric grid and emergency thermal energy is provided by the AEI steam system. During the off- 
peak period when the cogeneration system is not running, the system acts as an emergency-generator facility. The cogeneration facility is started automatically if an interruption occurs in the electric power or steam supply.

\subsection{Scenario 12: Install Gas Turbines and Operate On-Peak Period}

Under this scenario, the existing engine generators are replaced with two new gas turbine generators with a total electric capacity similar to that of the existing system. The new generators specified have a heat rate of $14,620 \mathrm{Btu} / \mathrm{kWh}$ based on the HHV of the fuel, corresponding to an electrical efficiency of $\mathbf{2 2 . 5 \%}$ at full load. The turbines selected for this analysis are rated at $1,540 \mathrm{~kW}$ each as in Scenario 10. The new turbines are equipped with new control systems. The new controls are capable of reliably starting the engines automatically, controlling the air-to-fuel ratio, and controlling the engine loading.

The gas turbines require a new heat recovery system. It is estimated that $45 \%$ of the input energy can be recovered as useful thermal energy, still providing more than enough energy to meet the thermal energy requirements.

The cogeneration facility operates both turbines at the full-load rating of $1,540 \mathrm{~kW}$ during the SDG\&E on-peak period. Scheduled downtime is assumed to be approximately $3 \%$. During the semipeak and off-peak periods, electric power is supplied by SDG\&E and thermal energy requirements are supplied by AEI steam. The cogeneration facility is staffed as outlined in Scenario 6. Special training is provided to the staff on gas turbines.

Part of the responsibility of the cogeneration staff is to monitor and operate the central chilledwater facility. Because the plant will not be staffed continuously, the chilled-water system will be equipped with new automated valves and controls to respond to equipment failures. Should a chiller, cooling tower, or pump fail, the new control system will shut down the failed component and automatically start another. The new system will be an expansion to the existing Johnson Controls system that currently monitors and controls much of the central HVAC system.

The new gas turbines have a total estimated life of 180,000 run-hours or 30 years (maximum). At the proposed operating schedule $(1,154 \mathrm{~h} /$ engine $\mathrm{yr}$ ) beginning in 1995, the new turbines will not need to be replaced in the life-cycle cost analysis period. At the end of the analysis period, it is estimated that the turbines will have approximately $17 \%$ of their economic life remaining because of the age of the turbines. The heat recovery system, however, has a longer estimated life and will not need to be replaced within the life of this analysis. The salvage value of the existing engines is estimated to be $\$ 50,000$ each (in 1993); however, it is assumed that this will cover the cost of their removal, sale, and transfer.

While the cogeneration system is running, emergency electric power is provided by the SDG\&E electrical grid and emergency thermal energy is provided by the AEI steam system. During the semipeak and off-peak periods when the cogeneration system is not running, the system acts as an emergency-generator facility. The cogeneration system is started automatically if an interruption occurs in the electric power or steam supply. 


\subsection{Scenario 13: Convert Plant to Emergency-Generator Status for Electrical and Thermal Energy}

Under this scenario, the existing cogeneration facility is converted to an emergency-generator facility. SDG\&E provides the NCTS facility with primary electric energy. AEI provides primary thermal energy. The cogeneration system is automatically started if an interruption occurs in the electric power or steam supply.

The existing engines are repaired to reliable operating status as automatic-start emergency generators, which includes new load-sharing and speed controls, new air-fuel ratio controllers, and additional repairs as outlined in Appendix $I$.

It is assumed that each emergency generator is tested under no load approximately one hour each week and under full load approximately one hour each quarter. ${ }^{\left({ }^{)}\right)}$It is also assumed that the emergency generator facility is staffed by one watch stander (WG-11) when the generators are operating.

Part of the responsibility of the cogeneration staff is to monitor and operate the central chilledwater facility. Because the plant will not be staffed continuously, the chilled-water system will be equipped with new automated valves and controls to respond to equipment failures. Should a chiller, cooling tower, or pump fail, the new control system will shut down the failed component and automatically start another. The new system will be an expansion to the existing Johnson Controls system that currently monitors and controls much of the central HVAC system.

\subsection{Scenario 14: Convert Plant to Emergency-Generator Status and Install Backup Boiler}

Under this scenario, the cogeneration facility is converted to an emergency-generator facility. The NCTS facility is provided with primary electric energy by SDG\&E and AEI provides primary thermal energy. The cogeneration system is automatically started if an interruption occurs in the electric power supply. In case of interruption in the steam supply, a new fast-start natural-gas-fired hot-water boiler is automatically started.

The existing engines are repaired to reliable operating status as automatic-start emergency generators as discussed in Scenario 13. In addition, the existing heat recovery system is disconnected and abandoned-in-place. The cooling tower is still used to provide engine cooling.

A new natural-gas-fired water boiler is also installed and interconnected to the thermal energy system using heat exchangers in a closed-loop system. The boiler is in cold standby during standard operating conditions.

(a) Facsimile Communication, John Thomas, PWC Code 610, for Douglas McDaniel, NCTS SD N42. May 4, 1993, 9:10 a.m. PDT. 
It is assumed that each emergency generator is tested under no load approximately one hour ach week and under full load approximately one hour each quarter. It is also assumed that the emergency-generator facility is staffed by one watch stander (WG-11) when the generators are operating.

Part of the responsibility of the cogeneration staff is to monitor and operate the central chilledwater facility. Because the plant will not be staffed continuously, the chilled-water system will be equipped with new automated valves and controls to respond to equipment failures. Should a chiller, cooling tower, or pump fail, the new control system will shut down the failed component and automatically start another. The new system will be an expansion to the existing Johnson Controls system that currently monitors and controls much of the central HVAC system.

\subsection{Scenario 15: Replace Plant with Emergency Generators and Backup Boiler}

Under this scenario, the cogeneration facility is replaced with a new emergency-generator facility. The NCTS facility is provided with primary electric energy by SDG\&E and AEI provides primary thermal energy. The new generators are automatically started if an interruption occurs in the electric power supply. If an interruption occurs in the steam supply, a new fast-start natural-gas-fired water boiler is automatically started.

The existing engines are replaced with four new automatic-starting emergency generators rated at $600 \mathrm{~kW}$, which includes a complete new control system. The existing heat recovery system is also disconnected and abandoned-in-place.

In addition, a new natural-gas-fired water boiler is installed and interconnected to the thermal energy system using heat exchangers in a closed-loop system. The boiler is in cold standby during standard operating conditions.

It is assumed that each emergency generator is tested under no load approximately one hour each week and under full load approximately one hour each quarter. ${ }^{\left({ }^{(}\right)}$It is also assumed that the emergency-generator facility is staffed by one watch stander (WG-11) when the generators are operating.

Part of the responsibility of the cogeneration staff is to monitor and operate the central chilledwater facility. Because plant will not be staffed continuously, the chilled-water system will be equipped with new automated valves and controls to respond to equipment failures. Should a chiller, cooling tower, or pump fail, the new control system will shut down the failed component and automatically start another. The new system will be an expansion to the existing Johnson Controls system that currently monitors and controls much of the central HVAC system.

(a) Facsimile Communication, John Thomas, PWC Code 610, for Douglas McDaniel, NCTS SD N42. May 4, 1993, 9:10 a.m. PDT. 


\subsection{Scenario 16: Utilize SDG\&E Interruptible Schedule I-3, Rate D, vith Scenario 13}

Under this scenario, the cogeneration facility is modified as in Scenario 13. In addition, PWCSD incorporates the SDG\&E Interruptible Schedule I-3, Rate D. This schedule is more fully discussed in Section 3.1. This rate schedule option provides a monthly credit to the electric utility bill. In return for this credit, PWCSD agrees to operate the emergency generators, at SDG\&E's request, to reduce the NASNI electrical demand. This rate schedule, and its subject facilities, is used by SDG\&E as another generating source when needed.

Schedule I-3, Rate D, allows SDG\&E to give PWCSD 30-minutes' notice, by telephone, to start the emergency generators, get them up to capacity, and on-line. SDG\&E also notifies PWCSD when the generators are no longer required. These interruptions typically occur less than 30 times per year for total engine operating hours of less than $80 \mathrm{~h} / \mathrm{yr}$. These are typical maximums according to SDG\&E; however, the contract allows SDG\&E to require additional interruptions for longer operating periods. This analysis assumes an average interruption of $56 \mathrm{~h} / \mathrm{yr} .{ }^{(\mathbf{a})}$ Incorporating this rate option requires a contractual agreement. The contract can be for a 1-year or 5-year term. Because the incentive is greater for the longer contractual agreement, this scenario assumes PWCSD will enter into 5-year contracts.

It is assumed that the emergency-generator facility is staffed by one watch stander (WG-11) when the generators are operating. It is also assumed that each emergency generator is tested under no load approximately one hour each week and under full load approximately one hour each quarter, ${ }^{(b)}$ in addition to operation at the request of SDG\&E under the new rate option.

Part of the responsibility of the cogeneration staff is to monitor and operate the central chilledwater facility. Because the plant will not be staffed continuously, the chilled-water system will be equipped with new automated valves and controls to respond to equipment failures. Should a chiller, cooling tower, or pump fail, the new control system will shut down the failed component and automatically start another. The new system will be an expansion to the existing Johnson Controls system that currently monitors and controls much of the central HVAC system.

\subsection{Scenario 17: Utilize SDG\&E Interruptible Schedule I-3, Rate A, with Scenario 13}

Under this scenario, the cogeneration facility is modified as in Scenario 13. In addition, PWCSD incorporates the SDG\&E Interruptible Schedule I-3, Rate A. This schedule is more fully discussed in Section 3.1. This rate schedule option provides a monthly credit to the electric utility bill. In return for this credit, PWCSD agrees to allow SDG\&E to operate the emergency generators,

(a) Facsimile Communication, Sharon Gorden, SDG\&E. April 30, 1993, 9:00 a.m. PDT.

(b) Facsimile Communication, John Thomas, PWC Code 610, for Douglas McDaniel, NCTS SD N42. May 4, 1993, 9:10 a.m. PDT. 
at SDG\&E's request, to reduce the NASNI electrical demand on the SDG\&E system. This rate schedule, and its subject facilities, is used by SDG\&E as another generating source when needed.

Schedule I-3, Rate A, allows SDG\&E to give PWCSD 10-minutes' notice, by telephone, and start the emergency generators remotely. These interruptions typically occur less than $\mathbf{3 0}$ times per year for total engine operating hours of less than $80 \mathrm{~h} / \mathrm{yr}$. These are typical maximurns according to SDG\&E; however, the contract allows SDG\&E to require additional interruptions for longer operating periods. This analysis assumes an average interruption of $56 \mathrm{~h} / \mathrm{yr} .^{\left({ }^{()}\right)}$Incorporating this rate option requires a contractual agreement. The contract can be for a 1-year or 5-year term. Because the incentive is greater for the longer contractual agreement, this scenario assumes PWCSD will enter into 5-year contracts.

It is assumed that the emergency-generator facility is staffed by one watch stander (WG-11) when the generators are operating. It is also assumed that each emergency generator is tested under no load approximately one hour each week and under full load approximately one hour each quarter, ${ }^{(0)}$ in addition to operation at the control of SDG\&E under the new rate option.

Part of the responsibility of the cogeneration staff is to monitor and operate the central chilledwater facility. Because the plant will not be staffed continuously, the chilled-water system will be equipped with new automated valves and controls to respond to equipment failures. Should a chiller, cooling tower, or pump fail, the new control system will shut down the failed component and automatically start another. The new system will be an expansion to the existing Johnson Controls system that currently monitors and controls much of the central HVAC system.

\subsection{Scenario 18: Utilize SDG\&E Interruptible Schedule I-3, Rate D, with Scenario 14}

Under this scenario, the cogeneration facility is modified as in Scenario 14, including the installation of the backup boiler. In addition, PWCSD incorporates the SDG\&E Interruptible Schedule I-3, Rate D. This schedule is more fully discussed in Section 3.1. This rate schedule option provides a monthly credit to the electric utility bill. In return for this credit, PWCSD agrees to operate the emergency generators, at SDG\&E's request, to reduce the NASNI electrical demand. This rate schedule, and its subject facilities, is used by SDG\&E as another generating source when needed.

Schedule 1-3, Rate D, allows SDG\&E to give PWCSD 30-minutes' notice, by telephone, to start the emergency generators, get them up to capacity, and on-line. SDG\&E also notifies PWCSD when the generators are no longer required. These interruptions typically occur less than $\mathbf{3 0}$ times per year for total engine operating hours of less than $80 \mathrm{~h} / \mathrm{yr}$. These are typical maximums according to SDG\&E; however, the contract allows SDG\&E to require additional interruptions for longer operating

(a) Facsimile Communication, Sharon Gorden, SDG\&E. April 30, 1993, 9:00 a.m. PDT.

(b) Facsimile Communication, John Thomas, PWC Code 610, for Douglas McDaniel, NCTS SD N42. May 4, 1993, 9:10 a.m. PDT. 
periods. This analysis assumes an average interruption of $56 \mathrm{~h} / \mathrm{yr} .^{\left({ }^{(}\right)}$Incorporating this rate option requires a contractual agreement. The contract can be for a 1-year or 5-year term. Because the incentive is greater for the longer contractual agreement, this scenario assumes PWCSD will enter into 5-year contracts.

It is assumed that the emergency-generator facility is staffed by one watch stander (WG-11) when the generators are operating. It is also assumed that each emergency generator is tested under no load approximately one hour each week and under full load approximately one hour each quarter, $^{(b)}$ in addition to operation at the request of SDG\&E under the new rate option.

Part of the responsibility of the cogeneration staff is to monitor and operate the central chilledwater facility. Because the plant will not be staffed continuously, the chilled-water system will be equipped with new automated valves and controls to respond to equipment failures. Should a chiller, cooling tower, or pump fail, the new control system will shut down the failed component and automatically start another. The new system will be an expansion to the existing Johnson Controls system that currently monitors and controls much of the central HVAC system.

\subsection{Scenario 19: Utilize SDG\&E Interruptible Schedule I-3, Rate A, with Scenario 14}

Under this scenario, the cogeneration facility is modified as in Scenario 14, including the installation of the backup boiler. In addition, PWCSD incorporates the SDG\&E Interruptible Schedule I-3, Rate A. This schedule is more fully discussed in Section 3.1. This rate schedule option provides a monthly credit to the electric utility bill. In return for this credit, PWCSD agrees to allow SDG\&E to operate the emergency generators, at SDG\&E's request, to reduce the NASNI electrical demand on the SDG\&E system. This rate schedule, and its subject facilities, is used by SDG\&E as another generating source when needed.

Schedule 1-3, Rate A, allows SDG\&E to give PWCSD 10-minutes' notice, by telephone, and start the emergency generators remotely. These interruptions typically occur less than 30 times per year for total engine operating hours of less than $80 \mathrm{~h} / \mathrm{yr}$. These are typical maximums according to SDG\&E; however, the contract allows SDG\&E to require additional interruptions for longer operating periods. This analysis assumes an average interruption of $56 \mathrm{~h} / \mathrm{yr} .^{(a)}$ Incorporating this rate option requires a contractual agreement. The contract can be for a 1-year or 5-year term. Because the incentive is greater for the longer contractual agreement, this scenario assumes PWCSD will enter into 5-year contracts.

It is assumed that the emergency-generator facility is staffed by one watch stander (WG-11) when the generators are operating. It is also assumed that each emergency generator is tested under

(a) Facsimile Communication, Sharon Gorden, SDG\&E. April 30, 1993, 9:00 a.m. PDT.

(b) Facsimile Communication, John Thomas, PWC Code 610, for Douglas McDaniel, NCTS SD N42. May 4, 1993, 9:10 a.m. PDT. 
no load approximately one hour each week and under full load approximately one hour each quarter, ${ }^{(\boldsymbol{a})}$ in addition to operation at the control of SDG\&E under the new rate option.

Part of the responsibility of the cogeneration staff is to monitor and operate the central chilledwater facility. Because the plant will not be staffed continuously, the chilled-water system will be equipped with new automated valves and controls to respond to equipment failures. Should a chiller, cooling tower, or pump fail, the new control system will shut down the failed component and automatically start another. The new system will be an expansion to the existing Johnson Controls system that currently monitors and controls much of the central HVAC system.

(a) Facsimile Communication, John Thomas, PWC Code 610, for Douglas McDaniel, NCTS SD N42. May 4, 1993, 9:10 a.m. PDT. 


\subsection{Utility Rate Schedules}

There are three energy sources affected by operating the cogeneration system: electricity, natural gas, and steam. The following is a discussion of these energy sources and their costs.

\subsection{Electricity}

Electric power is provided to NASNI from SDG\&E under Schedule A6-TOU at the transmission rate. The current rate structure is shown in Table 3.1. Power generated by the NCTS cogeneration facility reduces the amount of power purchased from SDG\&E. This avoided electric cost is treated as a savings, or positive cash flow, in the economic analysis.

In addition to standard electric service, the NCTS cogeneration facility is also subject to the SDG\&E Schedule S standby service rate. This schedule is applicable to standby or breakdown service where all or part of the customer's electric requirements are supplied by a generation source other than the utility, which is located on the customer's premises. This schedule is not applicable to customers who have chosen, in the generation agreement, to sell power to the utility on a simultaneous purchase and sale basis. Because the NCTS cogeneration facility generates power for use at NASNI and does not sell energy to SDG\&E, this schedule is applicable. The standby charge is $\$ 0.99 / \mathrm{kW}$ of contracted demand per month. The contracted demand is the full rated output, or nameplate rating, of the NCTS cogeneration facility, which is $2,600 \mathrm{~kW}(4 \times 650 \mathrm{~kW})$.

If the cogeneration facility is converted to an emergency-generator facility, it can incorporate the SDG\&E Schedule I-3 Interruptible rate. This rate schedule provides a monthly credit to the NASNI electric utility bill for contracting with SDG\&E to operate the generators on SDG\&E's demand under special conditions, thereby interrupting a portion of SDG\&E's demand. The period of interruption under this schedule can occur at any time at the utility's sole judgement, although special conditions usually do prevail. The utility can interrupt the load, requiring the engines to operate up to. 30 times per year with a total interruption time usually below $80 \mathrm{~h} / \mathrm{yr}$, but not less than $5 \mathrm{~h} / \mathrm{yr}$. Scenarios 16 through 19 assume an average interruption of $56 \mathrm{~h} / \mathrm{yr}$. There are four rate options available under Schedule I-3 summarized in Table 3.2. Each rate option is available through 1-year or 5-year contracts. For purposes of this analysis, 5-year contracts are assumed.

\subsection{Natural Gas}

SDG\&E provides natural gas to NASNI under the Schedule GPTCI rate. The cost of natural gas has a procurement component and a transportation component. In addition, the transportation component has a cogen rate and a non-cogen rate. The amount of natural gas applicable to the cogen rate is defined as the lesser of 1) the amount of gas used by the cogeneration equipment, and 2) the cogeneration gas allowance (CGA). The CGA is defined as the amount of gas required by the utility to generate and transmit an equivalent amount of electricity based on the utility's average annual incremental heat rate (IHR) (presently 10,688 Btu/kWh), which includes transmission line losses. 
Table 3.1. Schedule A6-TOU Transmission Rate

\author{
Customer Charge \\ Demand Charge: \\ Per $k W$ of noncoincident demand \\ Per $k W$ of maximum demand at \\ the time of system peak

\section{Energy Charge:} \\ All on-peak $k W h$, per $k W h$ \\ Plus all semi-peak $k W h$, per $k W h$ \\ Plus all off-peak $k W h$, per $k W h$
}

\section{Summer}

5600.00

$\$ 1.24$

$\$ 13.39$

$\$ 0.06886$

$\$ 0.04533$

$\$ 0.03369$
Winter

$\$ 600.00$

$\$ 1.24$

$\$ 2.17$

S0.06171

S0.03864

$\$ 0.03186$

Time Periods:

On-Peak

Semi-Peak

Off-Peak

\author{
Summer (May 1 through Sep 30) \\ 11:00 a.m. - 6:00 p.m. weekdays \\ 6:00 a.m. - 11:00 \&.m. weekdays \\ 6:00 p.m. - 10:00 p.m. weelideys \\ 10:00 p.m. - 6:00 a.m. woekday \\ Plus weekends and holidays
}

\author{
Winter (Oct 1 through Apr 30) \\ 5:00 p.m. - 8:00 p.m. weekdays \\ 6:00 a.m. - 5:00 p.m. weekdays \\ 8:00 p.m. - 10:00 p.m. weekdays \\ 10:00 p.m. - 6:00 a.m. weekdays \\ Plus weekends and holidays
}

The cogeneration gas allowance is currently 0.107 therm/ $/ \mathrm{kWh}$, but has varied in the past. The natural gas consumed above the CGA is billed at the non-cogen rate. In addition to the transportation and procurement cost components, there is also a state regulatory fee.

These cost components can vary slightly from month to month as the price of natural gas fluctuates. The cost of natural gas used in this analysis is based on the 1992 cost components as billed, shown in Appendix B. Table 3.3 shows the average natural-gas costs for 1992.

To qualify for the cogen gas rate, the NCTS cogeneration facility must meet the qualified facility (QF) requirements as defined by the FERC. This qualification is done on an annual basis and presented to SDG\&E. Calculations supporting the qualification based on 1992 data are located in Appendix $C$. If the cogeneration facility fails to qualify, all natural-gas consumption is charged at the non-cogen rate.

\subsection{Steam}

The NASNI steam loop supplies steam to the NCTS facility. NASNI is supplied 100-psig saturated steam from AEI under a custom contract. AEI operates another cogeneration facility nearby. Power and steam from AEI are provided to NASNI at very advantageous rates. The steam sales contract has 10 major components, several of which are basically fixed costs that are adjusted either quarterly or annually and are not related to the amount of steam consumed. 
Table 3.2. Schedule I-3 Interruptible Rate Options

\section{Rate A:}

Applicable where the customer elects to provide utility-controlled interruptible load within ten minutes of notice of interruption.

For aech kW of guananteed interruptible loed, per month, per kW

Plus for each interruption during the monthly billing period, per $\mathrm{kW}$

\section{Rate B:}

Applicable where the customer elects to provide customer-controlled interruptible load within ten minutes of notice of interruption.

For each $\mathrm{kW}$ of guaranteed interruptible load, per month, per $\mathrm{kW}$

Plus for each interruption during the monthly billing period, per $\mathrm{kW}$

$\$ 0.28$

\section{Rate C:}

Applicable where the customer elects to provide utility-controlled interruptible load within thirty minutes of notice of interruption.

For each $\mathrm{kW}$ of guaranteed interruptible load, per month, per $\mathrm{kW}$

Plus for each interruption during the monthly billing period, per $\mathrm{kW}$

\section{Rate D:}

Applicable where the customer elects to provide customer-controlled interruptible load within thirty minutes of notice of interruption.

For each $\mathrm{kW}$ of guaranteed interruptible load, per month, per $\mathbf{k W}$

Plus for each interruption during the monthly billing period, per $\mathrm{kW}$

$\$ 0.28 \$ \$ 0.28$

Thermal energy generated and recovered by the NCTS cogeneration facility results in steam that would otherwise have to be purchased from AEI. This avoided steam cost is treated as a savings, or positive cash flow, in the economic analysis.

Because this analysis is concerned with the avoided cost of thermal energy, the fixed-steam costs are not considered. The avoided cost of steam consists of three components: feedwater cost, condensate return credit, and the energy adjustment credit. The feedwater cost is a straightforward charge of $\$ 1.73 / \mathrm{Mlb}$ of steam. The condensate credit reduces the steam charge based on the amount of condensate returned from NASNI and accepted by AEI, which is presently $\$ 1.59 / \mathrm{Mlb}$. To date, this return rate has averaged $54 \%$ of the steam consumption. All steam consumed at the NCTS facility can be returned as condensate; however, there is the possibility of flash steam losses and leaks in the condensate return system. Condensate return is also regularly tested and screened by AEI for water quality. Condensate returned of unacceptable quality receives no credit. Therefore, the condensate 
Table 3.3. Average Costs of Natural Gas for 1992

Summer (\$) Winter (\$)

\section{Cogen Rate:}

Procurement

0.20559

0.18704

Transmission

0.09740

0.12114

Regulatory fee

0.00076

0.00076

Total, per therm

0.30375

0.30895

\section{Non-Cogen Rate:}

\section{Procurement}

0.20559

0.18704

Transmission

0.14550

0.17842

Regulatory fee

0.00076

0.00076

Total, per therm

0.35185

0.36622

\section{Seasons:}

Summer

April 1 through November 30

Winter

credit is calculated to be $54 \%$ of $\$ 1.59 / \mathrm{Mlb}$ of steam consumed or $\$ 0.86 / \mathrm{Mlb}$. The energy adjustment credit is more difficult to verify. A combined-cycle cogeneration facility is operated by AEI. Steam from that cogeneration facility is also used to generate electric energy. When less steam is extracted from the turbines to supply NASNI, AEI can use that steam to generate additional electric energy. One component of the energy adjustment credit is to return part of this opportunity savings back to NASNI. The energy adjustment credit varies and is updated quarterly. The avoided cost of this component is estimated to be $\$ 1.09$ and $\$ 0.72 / \mathrm{Mlb}$ of steam during the summer and winter billing seasons, respectively. ${ }^{(a)}$ The summer and winter seasons are the same as those in the SDG\&E electric rate schedule.

Steam is delivered at 100 -psig saturated vapor and condensate is passed at 100-psig saturated liquid. From the steam tables, the thermal energy available is $882 \mathrm{Btu} / \mathrm{lb}$ of steam. The avoided cost of steam is therefore $\$ 0.222$ therm and $\$ 0.180 /$ therm during the summer and winter billing seasons, respectively.

(a) Personal Communication, Robert Miner, SWDIV Code 1632.RM, and John Thomas, PWC Code 610. February 2, 1993, 3:00 p.m. PST. 


\subsection{Analysis}

\subsection{Cogeneration Operating Strategy}

There are four basic operating strategies for controlling the load of a cogeneration system: base loading, electrical load following, thermal load following, and economic load following. These load strategies are discussed below.

\subsubsection{Base Loading}

Under this operating strategy, the cogeneration system runs at a fixed load, usually full-rated output. The cogeneration system usually meets only part of the electric or thermal energy requirements.

If the cogeneration system does not meet the electric or thermal energy requirements of the facility, the cogeneration system provides the facility base load while the electric utility provides any additional electric energy; and a supplemental thermal energy system, such as a boiler, provides any additional thermal energy requirements. If the cogeneration system does not meet the electrical load, additional electric energy is provided by the electric utility. If excess electric energy is generated, it is sold to the electric utility. Similarly, if the cogeneration system does not meet the thermal energy demand, additional thermal energy is provided from another source. If excess thermal energy is generated, it is exported or rejected to a heat sink such as a cooling tower.

\subsubsection{Electrical Load Following}

Under this operating strategy, the electrical output of the cogeneration system increases or decreases to meet the electric demand of the supported facility, making it independent of the electric utility. Therefore, the cogeneration output follows the facility's electric demand or load. Thus, this control strategy is referred to as "electrical load following." The resulting thermal energy that is recovered can be greater than or less than the thermal energy requirements. If more thermal energy is required, then a supplemental thermal energy system, such as a boiler, is needed to meet the demand. If excess thermal energy is available, then it must be exported or rejected to a heat sink such as a cooling tower.

\subsubsection{Thermal Load Following}

Under this operating strategy, the output of the cogeneration system increases or decreases to meet the thermal energy requirements of the supported facility. Therefore, the cogeneration output follows the thermal energy demand or load. Thus, this control strategy is referred to as "thermal load following." The electric energy generated can be greater than or less than the electric energy requirements of the facility. If more electric energy is required, the electric utility provides the remaining demand. If excess electric energy is generated, then it flows out into the electric grid and is thus sold to the electric utility. 


\subsubsection{Economic Load Following}

With the advent of time-of-use and seasonal utility rates, the optimal cogeneration operating strategy may switch between base loading, electrical load following, or thermal load following from one period to the next because of the varying utility rates. Changing the active control strategy based on economic factors is referred to as "economic load following." For example, during the on-peak electric rate period, the optimal strategy may be electrical load following or base loading. However, during the off-peak electric rate period, when the cost of electric energy is much less, the optimal load strategy may be thermal load following. New computerized control systems can be programmed with current energy costs, make dynamic decisions as to which operating strategy is most economical, and automatically control the cogeneration system load to that optimal strategy.

\subsubsection{Marginal Energy Cost Analysis and Selection of Optimal Load Operating Strategy}

To determine which operating strategy is optimal for the NCTS cogeneration facility, a marginal energy cost analysis was performed. The marginal energy cost analysis utilized the costs that vary as a function of load, therefore, only energy costs were considered. Labor, materials, and maintenance costs were not considered in this analysis because they vary as a function of engine operating hours, but not necessarily as a function of engine load. The result of the marginal energy cost analysis does not determine whether or not it is cost effective to operate the cogeneration system; rather, it identifies at what load, or load strategy, the cogeneration system should operate.

Appendix $D$ contains the marginal energy cost analysis, assuming the cogeneration facility qualifies for the SDG\&E cogen gas rate. Appendix E contains the marginal energy cost analysis, assuming the cugeneration facility does not qualify for the SDG\&E cogen gas rate, but rather for the nor-cogen gas rate. In each of these analyses, there are two major cost categories: summer and winter. Within both of these categories, there are three minor subcategories: on-peak, semi-peak, and off-peak. There are more combinations because the definition of summer and winter seasons differ for the natural-gas utility and the electric utility, but only the primary combinations are considered in this analysis.

In Appendix D, Page D.4, the cost of the natural gas consumed is $\$ 22.63 /$ hengine with the engine running at full load during the summer on-peak time period. The value of the generated electric energy, excluding demand, is $\$ 41.32 / \mathrm{h}$ engine and the value of the thermal energy, assuming $100 \%$ of the recoverable energy is utilized, is $\$ 7.84 / \mathrm{h}$ engine. Because the value of the electric energy is greater than the value of the thermal energy, the electric energy is dominant. In addition, the value of the electric energy is more significant than the cost of the natural gas. Therefore, the engine should run at base (or full) load when in operation.

During the winter semi-peak period, however, the cost of the natural gas consumed is $\$ 23.10 / \mathrm{h}$ engine; the value of the electric energy generated at full load, excluding demand, is $\$ 23.18 / \mathrm{h}$ engine; and the value of the thermal energy, assuming $100 \%$ of the recoverable energy is utilized, is $\$ 6.36 / \mathrm{h}$ engine. The electric energy is still dominant over the thermal energy, but in itself is not greater than the cost of the natural gas. Under these conditions, the optimal load control strategy is electrical load following. 
The marginal energy cost analyses located in Appendix D and Appendix E can be used to determine the net energy savings that result from various combinations of the NCTS facility electrical and thermal requirements. Generally, a base loading control strategy is indicated, although in some circumstances electrical load following offers some minor improvement in economics. Therefore, economic load following would be the optimal control strategy with base loading a close second. Unfortunately, there is no electric consumption data available from the NCTS facility. For this

reason, all of the alternative scenarios consider the base load operating strategy. If the NCTS facility electric submetering demand and consumption information becomes available, the calculations can be re-evaluated for an economic load following control strategy.

\subsection{Determining the Thermal Load of the NCTS Facility}

A major component of this analysis is the thermal energy recovered and used from the cogeneration facility, which requires an understanding of the thermal load of the NCTS facility. The following sections estimate the existing thermal load of the facility and its anticipated growth.

\subsubsection{Present Thermal Load}

There are four thermal energy requirements within the NCTS facility: building cooling, reheat, building heat, and DHW. Cooling is provided by absorption chillers. There are three 400-ton absorption chillers in the NCTS facility. The peak cooling load, however, is estimated to be approximately 300 tons. Cooling is required throughout the year. Although not submetered, the facility maintains detailed $\log$ records on the cooling energy requirements. This information is used to calculate the useful thermal energy to qualify for the SDG\&E cogen gas rate. The required thermal energy for the cooling load can be estimated from the Cogeneration Data Summary (see Appendix C) and the PWCSD Metered Utility Report for steam (see Appendix A). This information is summarized in Table 4.1. The required thermal energy for the cooling load during the AEI summer billing period is approximately 176,330 therms/yr and during the winter billing period is approximately 234,460 therms/yr. There are no records, however, of the thermal energy requirements for the reheat, heating, or DHW systems.

Because the DHW system is not submetered, the energy requirements for this thermal load are estimated using energy-use intensities (EUIs) based on national estimates. The EUIs used for DHW are shown in Table 4.2. The NCTS facility consists of three major categories: 1) administration, computer and telecommunications area (office), 2) warehouse, and 3) the cogeneration plant (miscellaneous). The grcss floor areas of the office, warehouse and cogeneration plant are 31,425, 53,550 , and $10,350 \mathrm{ft}^{2}$, respectively. Using the EUIs for these categories, the DHW energy requirements are estimated to be 9,980 therms/yr. This thermal load is divided between the AEI summer and winter billing periods based on the number of operating hours in each period. Therefore, the DHW load during the summer billing period is 4,183 therms/yr and during the winter billing period is 5,797 therms/yr.

No information is available for the heating or reheat loads of the NCTS facility. Since its original construction, the internal heat gain of the NCTS facility has significantly changed, mainly because of the miniaturization of computers. Therefore, the original facility construction documents 
Table 4.1. Thermal Energy Requirements for Cooling

\begin{tabular}{lrrrr}
$\begin{array}{l}1992 \\
\text { Month }\end{array}$ & $\begin{array}{c}\text { AEI } \\
\text { Season }\end{array}$ & $\begin{array}{c}\text { Cogen } \\
\text { (therms) }\end{array}$ & $\begin{array}{c}\text { Steam } \\
\text { (therms) }\end{array}$ & $\begin{array}{c}\text { Total } \\
\text { (therms) }\end{array}$ \\
\cline { 1 - 2 } Jan & W & 38,440 & 11,460 & 49,900 \\
Feb & W & 13,630 & 14,870 & 28,500 \\
Mar & W & 24,370 & 12,570 & 36,940 \\
Apr & W & 17,910 & 15,480 & 33,390 \\
May & S & 22,430 & 16,110 & 38,540 \\
Jun & S & 25,360 & 11,930 & 37,290 \\
Jul & S & 24,260 & 9,860 & 34,120 \\
Aug & S & 28,260 & 5,750 & 34,010 \\
Sep & S & 21,120 & 11,250 & 32,370 \\
Oct & W & 27,700 & 3,620 & 31,320 \\
Nov & W & 26,800 & 350 & 27,150 \\
Dec & W & 26,830 & $\underline{430}$ & $\underline{27,260}$ \\
Summer & & 121,430 & 54,900 & 176,330 \\
Winter & & 175,680 & 58,780 & 234,460 \\
Total & & 297,110 & 113,680 & 410,790
\end{tabular}

Table 4.2. Energy-Use Intensities for Domestic Hot Water

$\begin{array}{lr}\text { Office } & 14.6 \mathrm{kBtu} / \mathrm{ft}^{2} \cdot \mathrm{yr} \\ \text { Warehouse } & 8.6 \mathrm{kBtu} / \mathrm{ft}^{2} \cdot \mathrm{yr} \\ \text { Miscellaneous } & 7.6 \mathrm{kBtu} / \mathrm{ft}^{2} \cdot \mathrm{yr}\end{array}$

can no longer be used to estimate the facility heating load or the reheat energy requirement estimate. The NCTS facility can still be classified as a thermally heavy building, meaning that there are significant internal heat gains. This is supported by documented cooling requirements that indicate the facility requires cooling throughout the year; thus, the heating and reheat loads are assumed to be negligible. This may be a weak assumption and has minimal impact on the overall economic analysis.

Referring to the energy analysis calculations discussed in Section 4.3.1 for Scenario 1 (statusquo operation), if the total required thermal energy estimate were to be off by as much as $25 \%$, the net energy savings would be off by only approximately $10 \%$. Because the cooling load is by far the largest thermal energy load, the estimate of the total thermal energy requirements should be 
reasonably accurate. The NCTS cogeneration facility is currently installing additional metering capabilities. If more accurate thermal energy consumption information becomes available, this assumption may be revised.

\subsubsection{Growth of Thermal Load}

The U.S. Department of Defense (DOD) is presently undergoing a phase of reduction and consolidation and this trend is anticipated to continue. The resulting impact to NASNI is internal growth. This growth will impact the NCTS facility and, therefore, the cogeneration facility. It has been estimated that the avera ye electrical load of the NCTS facility will increase from the present $1,100 \mathrm{~kW}$ to a projected $2,000 \mathrm{~kW}$ at about $3 \% / \mathrm{yr} .^{(\mathrm{a})}$

The facility's cooling requirements will increase as the electric load increases. The increased electrical consumption in the NCTS facility will directly increase the internal heat gain. The increasing load will also be accompanied by additional personnel within the facility. For these reasons, it is assumed that the required thermal energy (i.e., cooling and DHW) from the cogeneration system will also increase at the same rate as the estimated electrical load. If there had been estimates for building heating and reheating, these loads would decrease as the internal heat gains increased until they were no longer applicable. Thermal energy analysis projections are located in Appendix F. These projections consider the growth in thermal energy requirements for the NCTS facility and the impact on the thermal energy recoverable from the cogeneration facility under Scenarios 1 through 12.

Scenarios 1, 2, and 3 become inadequate to meet the required electrical load under this anticipated growth. Because the cogeneration facility is interconnected to the SDG\&E electric grid, there is no problem during normal operation. However, if an emergency shutdown or failure of the SDG\&E electrical system were to occur, the cogeneration facility may not be capable of supplying the entire NCTS facility as early as 1995 (see Appendix F, p. F.2).

\subsection{Engineering and Economic Analysis}

The following sections discuss the engineering and economic analysis of the alternative scenarios. This includes the energy analysis calculations, operations and maintenance (O\&M) costs, emissions and related costs, implementation costs, and finally the life-cycle cost analysis.

\subsubsection{Energy Analysis Calculations}

A spreadsheet was designed to analyze the energy and energy cost information obtained from the operation of the NCTS cogeneration facility under a base loading control strategy. This information is summarized in Table 4.3. The calculations are included in Appendix G.

(a) Personal Communication, Robert Miner, SWDIV Code 1632.RM. 
Table 4.3. Summary of Energy and Energy Cost Information - NCTS Facility Under Base Loading Control Strategy

\begin{tabular}{|c|c|c|c|c|c|c|c|c|c|}
\hline$\underline{\text { Scenario }}$ & $\begin{array}{l}\text { Natural-Gas } \\
\text { Energy } \\
\text { Consumed } \\
\text { (therms/yr) }\end{array}$ & $\begin{array}{c}\text { Electric } \\
\text { Energy } \\
\text { Avoided } \\
(\mathrm{kWh} / \mathrm{yr}) \\
\end{array}$ & $\begin{array}{c}\text { Steam } \\
\text { Energy } \\
\text { Avoided } \\
\text { (therms/yr) }\end{array}$ & $\begin{array}{l}\text { Qualify } \\
\text { Cogen } \\
\text { Gas Rate } \\
(Y \text { or } N)\end{array}$ & $\begin{array}{c}\text { Natural } \\
\text { Gas Cost } \\
(\boldsymbol{S} / \mathrm{yr}) \\
\end{array}$ & $\begin{array}{c}\text { Electric } \\
\text { Energy } \\
\text { Savings } \\
\text { (\$/yr) }\end{array}$ & $\begin{array}{c}\text { SDG\&E } \\
\text { Backup } \\
\text { Cost } \\
(\mathbf{S} / \mathbf{y r}) \\
\end{array}$ & $\begin{array}{l}\text { Thermal } \\
\text { Energy } \\
\text { Savings } \\
(S / y r)\end{array}$ & $\begin{array}{c}\text { Net } \\
\text { Energy } \\
\text { Savings } \\
(\$ / y r) \\
\end{array}$ \\
\hline 1 & $1,224,819$ & $9,757,764$ & 294,539 & $\mathbf{Y}$ & 381,685 & 504,265 & 30,888 & 58,444 & 150,136 \\
\hline 2 & 570,464 & $4,544,712$ & 137,163 & $\mathbf{Y}$ & 177,763 & 334,150 & 30,888 & 27,197 & 152,696 \\
\hline 3 & 166,245 & $1,324,427$ & 40,309 & $\mathbf{Y}$ & 51,681 & 184,976 & 30,888 & 8,344 & 110,751 \\
\hline 4 & $2,528,652$ & $20,145,000$ & 408,281 & $\mathbf{N}$ & 901,752 & $1,033,644$ & 30,888 & 81,014 & 182,018 \\
\hline 5 & $1,177,728$ & $9,382,603$ & 190,132 & $\mathbf{N}$ & 419,959 & 682,439 & 30,888 & 37,699 & 269,291 \\
\hline 6 & 343,215 & $2,734,293$ & 55,875 & $\mathbf{N}$ & 121,806 & 375,605 & 30,888 & 11,566 & 234,477 \\
\hline 7 & $2,247,386$ & $20,480,750$ & 408,281 & $\mathbf{Y}$ & 686,518 & $1,050,872$ & 28,987 & 81,014 & 416,381 \\
\hline 8 & $1,046,728$ & $9,538,979$ & 190,132 & $\mathbf{Y}$ & 319,737 & 693,813 & 28,987 & 37,699 & 382,788 \\
\hline 9 & 308,039 & $2,779,864$ & 55,875 & $\mathbf{Y}$ & 92,992 & 381,865 & 28,987 & 11,566 & 271,452 \\
\hline 10 & $3,949,997$ & $25,852,750$ & 408,281 & $\mathbf{N}$ & $1,408,623$ & $1,326,510$ & 36,590 & 81,014 & $(37,689)$ \\
\hline 11 & $1,839,724$ & $12,041,007$ & 190,132 & $\mathbf{N}$ & 656,016 & 875,796 & 36,590 & 37,699 & 220,889 \\
\hline 12 & 536,135 & $3,509,009$ & 55,875 & $\mathbf{N}$ & 190,272 & 482,027 & 36,590 & 11,566 & 266,731 \\
\hline 13 & 7,185 & 0 & 0 & $\mathbf{N}$ & 2,418 & 0 & 0 & 0 & $(2,418)$ \\
\hline 14 & 7,185 & o & 0 & $\mathbf{N}$ & 2,418 & $\mathbf{0}$ & $\mathbf{0}$ & 0 & $(2,418)$ \\
\hline 15 & 7,185 & 0 & 0 & $\mathbf{N}$ & 2,418 & 0 & 0 & 0 & $(2,418)$ \\
\hline 16 & 24,675 & 134,400 & 0 & $\mathbf{N}$ & 8,180 & 148,839 & 0 & 0 & 140,659 \\
\hline 17 & 24,675 & 134,400 & 0 & $\mathbf{N}$ & 8,180 & 213,927 & 0 & $\mathbf{0}$ & 205,747 \\
\hline 18 & 24,675 & 134,400 & 0 & $\mathbf{N}$ & 8,180 & 148,839 & 0 & 0 & 140,659 \\
\hline 19 & 24,675 & 134,400 & 0 & $\mathbf{N}$ & 8,180 & 213,927 & 0 & 0 & 205,747 \\
\hline
\end{tabular}


The calculations in Appendix $G$ can be divided into four main sections. The first section identifies the cogeneration specifications and the operating schedule. The number of engines typically operating, their electrical output capacity, the SDG\&E backup contracted demand, engine generator heat rate, and recoverable thermal energy are identified in this section. The heat rate is the amount of input fuel required to generate $1 \mathrm{kWh}$ of electric energy and is based on the HHV of the fuel. The thermal energy recovery is the amount of thermal energy that can be recovered from the cogenerator as a percentage of input fuel.

The cogeneration operating schedule identifies when the cogeneration system operates. The schedule corresponds to the SDG\&E electric utility rate schedule. Additional information includes the total available operating hours $(8,760 \mathrm{~h} / \mathrm{yr})$, the scheduled downtime, and the resulting net operating hours. Scheduled downtime is for normal engine maintenance and overhauls. The net utilization of hours is the net operating hours divided by the available operating hours. The load utilization factor is the average percent load of the engine generators. Under the base loading strategy, the load utilization factor should be $100 \%$ or full load. The powerhouse load is the estimated electric energy consumption within the cogeneration facility as part of the cogeneration process. The powerhouse load, $1.25 \%$, is identified as a percentage of total electrical output from the cogeneration engines. This number was estimated from PWCSD metered utility reports (see Appendix A) during 1992.

The second section of the analysis reiterates the utility rate schedule and unit cost factors as discussed in Section 3.1. These schedules and unit costs are necessary to calculate the resulting costs and savings associated with operating the cogeneration facility.

The third section contains the resulting energy calculations. This section is divided into the various energy categories. Natural gas consumed by the cogeneration engines is identified at the top of this section. The spreadsheet automatically determines if the facility qualifies for the cogen or noncogen natural-gas rates (by calculating and examining the FERC efficiency) and applies the appropriate cost factors.

Gross electricity generated and net energy generated are then identified. The net electricity generated takes into account the electrical energy consumed as part of the powerhouse load.

The analysis then considers the thermal energy systems. The thermal energy recoverable is the amount of heat energy that can be recovered from the cogeneration system. The required thermal energy is the thermal demand of the NCTS facility, as discussed in Section 4.2, consisting of comfort cooling, comfort heating, reheat, and DHW. The analysis then estimates the thermal energy recoverable and useable. Because thermal energy storage is not possible, the thermal energy recovered must correspond with the thermal energy demand.

The final section of the analysis summarizes the energy costs and savings resulting from the operation of the cogeneration facility. In addition, the annual FERC efficiency is identified.

Appendix $\mathrm{G}$ contains the analysis for each of the scenarios concerning continued operation of the cogeneration facility. The scenarios that involve converting the cogeneration facility into an emergency-generator facility were determined separately. Because emergency downtime is a 
nonroutine occurrence, it can rarely be anticipated. This analysis assumes that emergency downtime does not actually occur. Under these conditions, no electric cost or steam cost is reduced. Natural gas however is consumed during the routine scheduled testing of the engines.

Under Scenarios 16 through 19, there would be reduced electric energy purchased when the SDG\&E interruption occurs. In addition, there may or may not be any resulting peak demand reduction. Because these interruptions can occur at any time, and for any duration, the results are difficult to estimate. For this analysis, it is assumed that the interruptions will occur, on average, $56 \mathrm{~h} / \mathrm{yr}$ over two months during the summer on-peak billing period. In addition to the interruptible rate credit, savings are calculated for the avoided energy consumption. Because NASNI peak demand typically occurs during the semi-peak period, no demand reduction savings are claimed.

\subsubsection{Operations and Maintenance Costs}

The O\&M costs are divided into the following six cost categories, except in the gas turbine and emergency-generator alternatives where maintenance costs are combined: PWCSD labor, PWCSD general maintenance, catalytic converter, subcontractor preventive maintenance, subcontractor corrective maintenance, and subcontractor engine overhaul. Each of these cosi categories has a significant impact on the overall economics of operating the cogeneration facility as shown in Table 4.4.

\subsubsection{Labor Costs}

Staffing requirements for PWCSD were noted in the discussion of alternative scenarios in Section 2.0. Staffing requirements were divided into three categories for the cogeneration alternatives: continuous operation, operate on-peak and semi-peak periods, and operate on-peak period. For continuous operation, PWCSD has requested staffing consist of one foreman on the day shift, one maintenance mechanic (WG-10) on the day shift, and five watch standers (WG-11) for rotating shifts. ${ }^{(a)}$ At current PWCSD labor rates, this equates to a total labor charge of $\$ 309,254$ per year. This staffing level is associated with alternative Scenarios 1, 2, 3, 4, 7, and 10.

For noncontinuous operation of the cogeneration system, additional assumptions are made. PWCSD standard work shifts do not coincide with SDG\&E time-of-use periods. It is assumed that PWCSD will staff the cogeneration facility one-half hour before the SDG\&E operational period begins and will relocate staff one-half hour after the SDG\&E operational period ends, requiring PWCSD staff to work partial days in the cogeneration facility and partial days elsewhere on the base.

For operation during the on-peak and semi-peak periods, PWCSD staffing is assumed to be one foreman on the day shift, one maintenance mechanic (WG-10) on the day shift, and one watch stander (WG-11) present one-half hour before scheduled operation until one-half hour after scheduled shutdown. The on-peak and semi-peak periods occur $16 \mathrm{~h} / \mathrm{d}$, Monday through Friday, excluding holidays for both the summer and winter seasons. At current PWCSD labor rates, this equates to a total labor charge of $\$ 265,980$ per year. This staffing level is associated with alternative Scenarios 5 , 8 , and 11 .

(a) Personal Communication, Robert Miner, SWDIV Code 1632.RM, and John Thomas, PWC Code 610. February 2, 1993, 3:00 p.m. PST. 
Table 4.4. Summary of Operations and Maintenance Costs

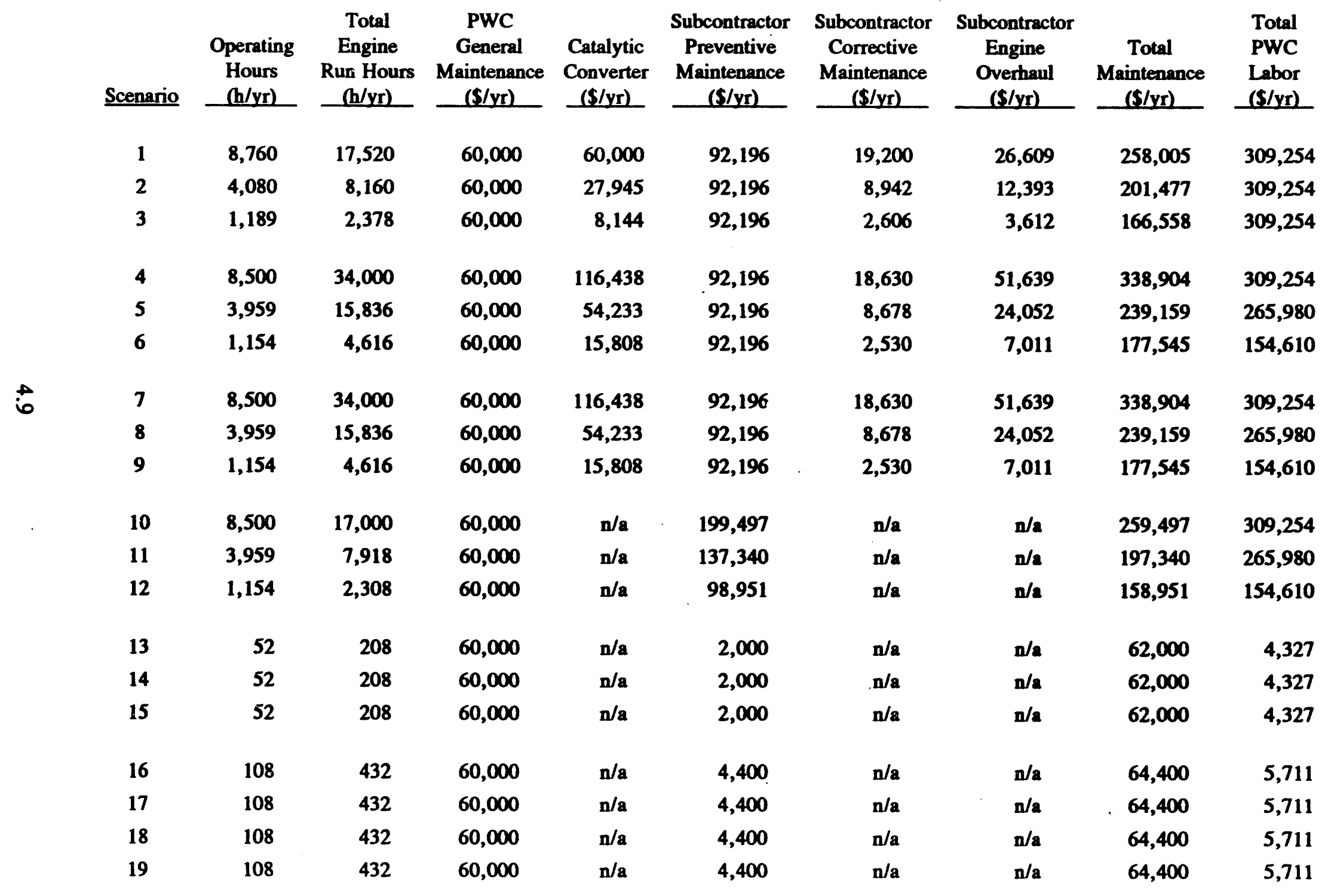


For operation during the on-peak period only, PWCSD staffing is assumed to be one foreman, one maintenance mechanic (WG-10), and one watch stander (WG-11) present one-half hour before scheduled operation until one-half hour after scheduled shutdown. The on-peak period occurs for $7 \mathrm{~h} / \mathrm{d}$, Monday through Friday during the summer season, excluding holidays, and for $3 \mathrm{~h} / \mathrm{d}$, Monday through Friday during the winter season, excluding holidays. At current PWCSD labor rates, this equates to a total labor charge of $\$ 154,610$ per year. This staffing level is associated with alternative Scenarios 6, 9, and 12 .

If the cogeneration facility is converted to an emergency-generator facility, staffing will occur during an outage and when engines are tested. Because, for purposes of this analysis, it has been assumed that outages will not normally occur, no labor costs are associated with this event. During the scheduled engine tests, staffing requirements are estimated to be one watch stancier (WG-11) for approximately four hours for each test. Under the directive of NCTS, there will be 48 no-load tests (one per week, except for quarterly full-load tests) and four full-load tests (one per quarter). ${ }^{(a)}$ At current PWCSD labor rates, this equates to a total labor charge of $\$ 4,327$ per year. This staffing level is associated with alternative Scenarios 13, 14, and 15.

Under Scenarios 16 through 19, the emergency generators are assumed to operate approximately $56 \mathrm{~h} / \mathrm{yr}$ in addition to the routine scheduled load tests. Assuming that interruption occurs 7 times per year, 8 hours per interruption, and that staff would arrive one-half hour before and depart one-half hour after interruption, the PWCSD labor cost for this scenario would be $\$ 5,711$ per year.

\subsubsection{Maintenance Costs}

PWCSD performs maintenance on the cogeneration facility, including the chiller plant, beyond that covered by the Pentech preventive maintenance contract. During 1992, these general maintenance costs were $\$ 60,000$. Maintenance costs can usually be related to the equipment run time. However, these maintenance costs are associated with the HVAC and auxiliary equipment, which will continue to operate in a similar fashion, and are therefore treated as a fixed cost.

The cogeneration engines have two catalytic converters in series. These catalytic converters are replaced after one year of operation at a cost of $\$ 15,000$ each. The annual cost of the catalytic converters is also assumed to be a function of engine operating hours for Scenarios 1 through 9 . In the emergency-generator alternatives, the life of the catalytic converters also is assumed to be a function of engine run time.

The maintenance requirements for the cogeneration engines are subcontracted by PWCSD. These maintenance requirements include: preventive maintenance, nonroutine maintenance, and engine overhauls. Although the cost of preventive maintenance should also be a function of operating hours, this is a point of contract negotiation. For the purpose of this analysis, it is assumed to be a fixed cost of $\$ 92,196$ per year for Scenarios 1 through 9.

(a) Facsimile Communication, John Thomas, PWC Code 610, for Douglas McDaniel, NCTS SD N42. May 4, 1993, 9:10 a.m. PDT. 
Corrective maintenance consists of special incidents. During the previous year, the cogeneration facility experienced around two incidents per month at a cost of $\$ 800$ per incident. These incidents are further outlined in Appendix I. The frequency of incidents is assumed to be a function of equipment run time for Scenarios 1, 2, and 3. Under the repair and replacement options (Scenarios 4 through 9), the incident rate is assumed to be $50 \%$ less or one incident per month.

The reciprocating engine generators are overhauled after every $20,000 \mathrm{~h}$ of engine run time, which is under contract to Pentech at a cost of $\$ 30,376$ per engine. This equates to an average cost of $\$ 1.52$ per engine run-hour, which is used to estimate the overhaul cost of each of the scenarios involving reciprocating engines.

The maintenance cost estimated for the gas turbine options is not separated into multiple categories. The total maintenance costs for the gas turbine scenarios are identified in the subcontractor preventive maintenance column in Table 4.4. The estimated maintenance costs are based on another gas turbine cogeneration facility located at the Naval Regional Medical Center (Zavala and Heller 1991). The hospital has three natural-gas-fired $800-\mathrm{kW}$ solar gas turbine generators. Maintenance costs at this facility are also subcontracted. This annual contract fee includes monthly visits, routine maintenance, emergency visits, overhauls, parts (except oil and filters), and contractor labor. The maintenance cost estimates for Scenarios 10, 11, and 12 were prorated based on operating capacity and engine run hours. These costs correlate well with maintenance costs found in California Energy Commission sources (CEC 1991).

The total maintenance costs for the emergency-generator options (Scenarios 13 through 19) are also identified in the subcontractor preventive maintenance column in Table 4.4, although it is assumed that all maintenance on the emergency generators would be performed by PWCSD personnel. The total maintenance costs for these options are derived from other PNL studies of emergencygenerator facilities (Richman et al. 1993; Dixon et al. 1992). The annual maintenance costs for Scenarios 13,14 , and 15 are estimated to be $\$ 2,000$. Scenarios 16 through 19 require additional operating hours, therefore the annual maintenance costs are estimated to be $\$ 4,400$. Maintenance cost for the backup boiler system of Scenarios $14,15,18$, and 19 are assumed to be negligible.

\subsubsection{Emissions and Related Costs}

\subsubsection{Summary of Findings}

The emissions costs associated with the NCTS cogeneration plant fall into two categories: the annual permitting cost and the opportunity cost of the emissions permits. The annual permitting cost is a fee paid directly to SDAPCD and is estimated at about $\$ 10,724$ per year. This fee would be discontinued if the plant were shut down and so represents a plant operating cost. In addition to this fee, there is the opportunity cost of operating the plant, which is derived from the emissions permits held by the plant. This opportunity cost is the value that could be obtained from the sale of the right to emit regulated pollutants. When the plant is operating, these rights must be held by the USN. If the plant were to reduce its level of operation or be closed down, some or all of these rights could be sold or saved for use on a different pollution emitting project. In either case, the closure or reduced operation of the plant would result in the production of a set of emissions permits with a market value. This market value is estimated to be at least $\$ 400,000$ if the plant were closed, which should 
be treated as a one-time lump sum obtained after the plant closure. If the plant were not closed but reduced its level of operation, the value of the saleable permits would be proportionally less. The permits should be valued at the market value, even if the USN were to save the permits for their own use, because possession of the permits would save the USN from having to purchase permits on the open market. For a more thorough discussion on emissions trading, see Appendix $\mathrm{C}$ in Economic Analysis of Operating Alternatives for the South Vandenberg Power Plant at Vandenberg Air Force Base, California (Daellenbach et al. 1993).

\subsubsection{Description of SDAPCD Regulations}

Permit schedules vary depending on the type and size of a facility. The schedule that the NCTS plant falls under charges an annual renewal fee per engine. The renewal fee covers all costs involved with testing and emissions fees and represents an average of the cogeneration plants of a given size. (a) This fee changes from year to year because it is calculated by dividing the number of engines tested into the total cost of testing, with a two-year lag. ${ }^{(1)}$ In other words, changes in testing costs and engine population for 1991 will be reflected in the renewal fee for 1993 . If an engine is going to be taken off line, the plant owner has two choices: the emissions can be banked or traded, or the engine can go to a nonoperational status.

For the emissions to be banked or traded, credits must be issued by SDAPCD. The number of credits is determined by the actual emission output of the engine averaged over the last two years of operation. Credits are only issued for emissions reductions that are real and permanent. ${ }^{(0)}$ The value of these credits is uncertain because of the newness of the market and the limited number of market transactions that have occurred. The value of the credits is also affected by whether the district is in attainment for a given pollutant; that is, whether the measured pollutants within the district meet state or federal limits. Within SDAPCD, the only pollutant in attainment is sulfur oxides (SOx). The district is in nonattainment for nitrogen oxides (NOx), particulate matter (PM), carbon monoxide (CO), and reactive organic compounds (ROCs). () Both attainment and nonattainment pollutants can be traded; however, district nonattainment pollutant levels imply a greater value for those credits.

Another alternative that the plant owner has is to place the engine on nonoperational status. The nonoperational status fee allows the owner to maintain the emissions permit in the event that the owner may want to bring the engine back on line.

(a) Personal Communication, Barney McIntire, San Diego Air Pollution Control District. February 23, 1993, 9:00 a.m. PST.

(b) Personal Communication, John Savel, Code 950B Public Works Center, Environmental Division. March 4, 1993, 9:45 a.m. PST.

(c) Personal Communication, Dan Speer, San Diego Air Pollution Control District. February 23, 1993, 8:30 a.m. PST.

(d) Personal Communication, Alberto Abreu, San Diego Air Pollution Control District. October 27, 1993. 


\subsubsection{The NCTS Cogeneration Plant}

The NCTS cogeneration plant consists of four 650-kW Caterpillar engines operated as rich burn using natural gas with a propane backup fuel supply, which are operated by PWCSD. Currently, the NCTS plant operates two engines continuously while maintaining a third engine for backup power. The engines are permitted for operation at $600 \mathrm{~kW}$, with a minimum operation level of $580 \mathrm{~kW}$ and a maximum level of $620 \mathrm{~kW}$ (see Appendix H) for natural-gas usage with diesel oil backup.() The engines were permitted at $600 \mathrm{~kW}$ instead of $650 \mathrm{~kW}$ because that is the maximum power level that the engines were able to achieve when tested.(i)

The engines are tested at least once a year by SDAPCD. According to the permits, each engine can emit up to $215 \mathrm{ppmv}$ of NOx and up to $350 \mathrm{ppmv}$ of CO. If an engine fails the emissions test, a notice of violation is issued and a fine is assessed. The plant operator will then shut down the violating engine to avoid additional fines, and begin the process of correcting the problem. Once the correction is made, an independent testing firm is brought in to retest the engine and SDAPCD sends an observer. After submission of a final report, the plant operator must go before a hearing board to ask that a variance be granted before the engine can be restarted. Operation of the engine during this time can result in large fines. Once the variance has been granted, the operator can bring the engine back to full operational status. (o)

The NCTS plant has received six to eight notices of violation in the past. The plant has been in compliance for the past year, however, primarily because of the purchase and use of a portable tester. The tester monitors the engine emissions so that problems can be quickly identified and corrected to avoid further violation notices.(b) For this reason, the variable costs associated with violation notices were not included in the analysis because it was assumed that the use of the portable tester would prevent future notices of violation.

\subsubsection{Development of Environmental Cost Estimate}

Each year, the NCTS must renew the permits on each of the operating engines. Currently, the permit fee for 1993 is $\$ 2,681$ per engine. If the NCTS plant decides to take an engine off line but retain the permits, the cost will be $\$ 147$ per engine per year. Calculating the opportunity cost of operating the engines is more complicated.

Table 4.5 summarizes the emissions per engine for 1991 (o) $^{(0)}$ SDAPCD does not test for SOx, and ROCs are a subset of total organic compounds (TOCs). Engines are identified by permit number, and pollutant levels are listed in tons.

(a) Personal Communication, John Savel, Code 950B Public Works Center, Environmental Division. March 4, 1993, 9:45 a.m. PST.

(b) Personal Communication, John Savel, Code 950B Public Works Center, Environmental Division. March 2, 1993, 8:15 a.m. PST.

(c) Personal Communication, Clay Hinkle, San Diego Air Pollution Control District. March 3, 1993, 4:30 j.m. PST. 
In 1991, however, the emissions of NOx and CO exceeded the permitted level, resulting in fines. Only actual, permitted emissions can be traded, so the potentially available credits are less than shown in Table 4.5. Table 4.6 shows the level of potentially available credits.

Assuming that these totals represent continuous operation of two engines, and that this level of operation would be maintained for 2 years prior to any shutdown, the next step is to assign a value to the available credits. Table 4.7 contains the best estimates of existing market prices for emission credits (Daellenbach et al. 1993).

Table 4.5. 1991 Annual Emissions Per Engine

\begin{tabular}{|c|c|c|c|c|c|}
\hline Pollutant & $\begin{array}{c}\text { Engine } \\
860537 \\
\text { (tons) }\end{array}$ & $\begin{array}{c}\text { Engine } \\
860538 \\
\text { (tons) }\end{array}$ & $\begin{array}{l}\text { Engine } \\
860539 \\
\text { (tons) }\end{array}$ & $\begin{array}{l}\text { Engine } \\
860540 \\
\text { (tons) }\end{array}$ & $\begin{array}{l}\text { Total } \\
\text { (tons) }\end{array}$ \\
\hline Nox & 1.8 & 1.7 & 20.1 & 17.2 & 40.8 \\
\hline TOC & 1.2 & 3.5 & 8.3 & 4.6 & $18.2^{(a)}$ \\
\hline ROC & 0.3 & 0.9 & 2.1 & 1.2 & $5.1^{(\omega)}$ \\
\hline CO & 0.2 & 1.3 & 2.5 & 3.3 & 7.3 \\
\hline PM & - & 0.1 & 0.1 & 0.1 & 0.3 \\
\hline
\end{tabular}

(a) Totals for TOC and ROC include $\mathbf{0 . 6}$ ton for metals coding.

Table 4.6. Potentially Available Emissions Credits

\begin{tabular}{cc} 
Pollutant & $\begin{array}{c}\text { Credit } \\
\text { (ton/yr) }\end{array}$ \\
\hline NOx & 34.4 \\
ROC & 5.1 \\
CO & 7.3 \\
PM & 0.3
\end{tabular}


Table 4.7. Estimated Value of Emission Reduction Credits

\begin{tabular}{cr} 
Pollutant & $\begin{array}{r}\text { Value } \\
\text { (s/ton) }\end{array}$ \\
\cline { 2 - 2 } ROC & 20,000 \\
NOx & 10,000 \\
SOx & 400 \\
CO & 400 \\
PM & 400
\end{tabular}

The $\$ 20,000$ price per ton for ROC is based on an actual sale that occurred in Ventura County Air Pollution Control District. The $\$ 10,000$ price per ton for NOx is a prediction based on the ROC sales price and the price of control technologies. There is a low but nonzero estimated price for SOx, although it is not a regulated pollutant. This is presumably because of some speculative demand to offset potential future regulations. While CO is regulated in SDAPCD, it is not in the Santa Barbara Air Pollution Control District; the district for which these figures were estimated. The $\$ 400$ price per ton from Santa Barbara is used here; however, it probably represents a lower bound estimate. These price estimates are very rough and should be treated as approximate lower bound estimates because this is a new, highly volatile market. As an example of the volatility, consider the experience in one district where an owner was made an offer of $\$ 1,000,000$ for five tons of SOx credits. The owner decided to keep the credits. ${ }^{(\boldsymbol{)})}$

By combining the information in Tables 4.6 and 4.7, the estimated value of permits held by the NCTS cogeneration plant is $\$ 449,040$ (see Table 4.8 ). This value would only be realized if the plant were to shut down entirely. Table 4.9 shows the value of the emissions permits used for each scenario based on their hours of operation. Table 4.9 also shows the value of the renewal fee, which is based on the number of permitted engines.

Table 4.8. Value of Emissions Permits

$\begin{array}{lrrr}\text { Pollutant } & \text { Ton } & \begin{array}{c}\text { Value } \\ \text { (\$/ton) }\end{array} & \begin{array}{c}\text { Estimated Value } \\ (\mathbf{S})\end{array} \\ \text { ROC } & 65.1 & 20,000 & 102,000 \\ \text { NOx } & 34.4 & 10,000 & 344,000 \\ \text { CO } & 7.3 & 400 & 2,920 \\ \text { PM } & 0.3 & 400 & \frac{120}{449,040} \\ \text { Total } & 41.4 & & \end{array}$

(a) Personal Communication, Bill Anderson, EMC Inc., February 25, 1993, 10:00 a.m. PST. 
Table 4.9. Value of Renewal Fee and Emissions Permits for the Life-Cycle Cost Analysis

\begin{tabular}{|c|c|c|c|}
\hline Scenario & $\begin{array}{c}\text { Engine } \\
\text { Operation } \\
(\mathrm{h} / \mathrm{yr}) \\
\end{array}$ & $\begin{array}{c}\text { Renewal } \\
\text { Fee } \\
(\mathbf{S} / \mathbf{y r}) \\
\end{array}$ & $\begin{array}{c}\text { Emissions } \\
\text { Permit Value } \\
(\$) \\
\end{array}$ \\
\hline 1 & 8,760 & 10,724 & 0 \\
\hline 2 & 4,080 & 10,724 & 223,898 \\
\hline 3 & 1,189 & 10,724 & 388,092 \\
\hline 4 & 8,500 & 10,724 & 13,328 \\
\hline 5 & 3,959 & 10,724 & 246,101 \\
\hline 6 & 1,154 & 10,724 & 389,886 \\
\hline 7 & 8,500 & 10,724 & 13,328 \\
\hline 8 & 3,959 & 10,724 & 246,101 \\
\hline 9 & 1,154 & 10,724 & 389,886 \\
\hline 10 & 8,500 & 5,362 & 13,328 \\
\hline 11 & 3,959 & 5,362 & 246,101 \\
\hline 12 & 1,154 & 5,362 & 389,886 \\
\hline 13 & 52 & 1,060 & 446,374 \\
\hline 14 & 52 & 1,060 & 446,374 \\
\hline 15 & 52 & 1,060 & 446,374 \\
\hline 16 & 108 & 1,060 & 443,504 \\
\hline 17 & 108 & 1,060 & 443,504 \\
\hline 18 & 108 & 1,060 & 443,504 \\
\hline 19 & 108 & 1,060 & 443,504 \\
\hline
\end{tabular}

(a) Must obtain new permit to operate at reduced level, and operate at the reduced level for two years before the value of emissions permits can be realized. Therefore, the proposed cash flow will occur in 1997.

\subsubsection{Implementation Costs}

The 19 scenarios can be divided into five main groups for implementation costs, which are status-quo, repair the existing engines, replace the engines with new reciprocating engines, replace the engines with new gas turbines, and convert the facility to emergency-generator status.

Scenarios 1, 2, and 3 are status-quo alternatives. There are no implementation costs for these alternatives. The engines continue to operate in their existing condition. 
Scenarios 4, 5, and 6 are repair alternatives. The Energy Technology Engineering Center (ETEC) was commissioned by PNL to further evaluate the condition of the existing cogeneration facility to identify necessary repairs required to bring the facility up to original specifications. The ETEC report is located in Appendix I. Repair costs are estimated to be $\$ 54,525$, which includes replacing the load-sharing and speed controls; the air-fuel ratio controller; service and tune-up of the governor actuators, Caterpillar engines; switch gear; and some electrical and instrumentation rewiring. In addition to the repairs to the engines and controls, PNL has also identified necessary modifications to the electrical switchgear, which is included in the implementation cost estimate. Because the plant will not be staffed continuously in Scenarios 5 and 6, the chilled-water system will be equipped with new automated valves and controls to better control the system and respond to equipment failures. Should a chiller, cooling tower, or pump fail, the new control system will shut down the failed component and automatically start another. The cost of this modification, including materials, labor, equipment, and engineering fees, is estimated to be $\$ 35,950$.

Scenarios 7, 8, and 9 assume the existing engines are replaced with new reciprocating engines. The total implementation cost for this set of alternatives is estimated to be $\$ 1,830,000$, which includes removing the existing engines and generators, purchasing new reciprocating engine generators, delivery, and installing and commissioning the new system (Rodden et al. 1986; Gerber 1988; CEC 1991). It is assumed that the salvage value of the existing engines would cover the cost of their removal. The existing waste heat recovery equipment is still used under these scenarios as discussed in Section 2.0. In addition to replacing the engines and controls, PNL has also identified necessary modifications to the electrical switchgear, which is included in the implementation cost estimate. Because the plant will not be staffed continuously in Scenarios 8 and 9, the chilled-water system will be equipped with new automated valves and controls to respond to equipment failures. The cost of this modification, including materials, labor, equipment, and engineering fees, is estimated to be $\$ 35,950$.

Scenarios 10,11, and 12 consider replacing the existing cogeneration system with a new gas turbine cogeneration system. Implementation of this alternative is estimated to be $\$ 5,554,000$, which includes removing the existing engines, generators, and waste heat recovery equipment; purchasing new gas turbines with generators and waste heat recovery equipment; delivery; installing and commissioning the new system; and training PWCSD personnel on the O\&M of the new system (Rodden et al. 1986; Gerber 1988; CEC 1991). In addition to replacing the cogeneration system, PNL has also identified necessary modifications to the electrical switchgear, which is also included in the implementation cost estimate. Because the plant will not be staffed continuously in Scenarios 11 and 12, the chilled-water system will be equipped with new automated valves and controls to respond to equipment failures. The cost of this modification, including materials, labor, equipment, and engineering fees, is estimated to be $\$ 35,950$.

Scenarios 13, 16, and 17 assume the cogeneration facility is converted to an emergencygenerator facility. In addition to the repairs noted in the repair alternatives described earlier (Scenarios 4,5 , and 6), it is estimated that additional servicing and conversion will be required (see Appendix I). The total implementation cost for these scenarios is estimated to be $\$ 100,425$.

Scenarios 14, 18, and 19 involve repairing the engines as described for Scenario 13, as well as installing a new 11.5 MBtu/h (output) boiler (approximately 350-boiler hp) to back up the AEI steam 
system. The new boiler is required to supply the peak thermal energy requirements of the NCTS facility, including the forecasted growth. The total implementation cost for this scenario is estimated to be $\$ 259,250$.

Scenario 15 involves replacing the entire cogeneration system with a new emergency-generator system and new backup boiler. Implementation of this alternative is estimated to be $\$ 2,024,725$, which includes removing the existing engines and generators, abandoning-in-place the waste heat recovery equipment, purchasing new emergency generators, purchasing the new boiler, installing new automated valves and controls, and installing and commissioning the new system.

Because the plant will no longer be staffed in any of the emergency-generator scenarios (Scenarios 13 through 19), the chilled-water system will be equipped with new automated valves and controls to respond to equipment failures. The cost of this modification, including materials, labor, equipment, and engineering fees, has been included in the implementation cost estimates. A summary of the implementation costs for all scenarios is shown in Table 4.10.

As noted in Sections 2.13 through 2.19, the emergency generators are to be tested under no load approximately one hour each week and under full load approximately one hour each quarter. Load banks are not included in the implementation cost estimate. Full-load tests will be accomplished by connecting the generators to the electric grid. The new engine controls are capable of automatically synchronizing with the electric grid.

\subsubsection{Life-Cycle Cost Analysis}

The alternative scenarios described in this report were evaluated on the basis of their life-cycle costs. Federal agencies are required to evaluate energy-related investments on the basis of minimum life-cycle costs (10 CFR 436). The life-cycle cost of an investment is the present value of all costs associated with the investment over time. The cost elements cannot simply be summed up when calculating the life-cycle cost because costs occurring at different points in time need to be treated differently (NBS 1987). This is accomplished through discounting using the federally mandated discount rate of 4.0\% (NIST 1992) and fuel escalation rates. In addition, competing alternatives must be analyzed over the same life. For alternatives with different estimated lifetimes, appropriate replacements at end of life, salvage values, and economic values must be considered. Twenty-five years is used as the common project life for this analysis with implementation occurring in 1995. The life-cycle cost of an alternative is calculated by summing the present value of all costs (implementation, energy, and O\&M). The net savings of an alternative is the difference between the life-cycle cost of the alternative and that of the existing system or base case. In this analysis the base case is Scenario 1.

The results of the life-cycle cost analysis for the 19 alternative scenarios are shown in Table 4.11 and are expressed in 1995 dollars (the implementation year). Because the emissions credit estimate is volatile, life-cycle costs and net savings are provided with and without the credit. Scenario 17 has the best life-cycle cost (least total cost), therefore the highest net savings. The next best alternative is Scenario 19. The only difference between these two scenarios is the backup boiler included in Scenario 19. The inclusion of a fast response backup boiler may be a technical requirement if the engines are not capable of providing backup thermal energy within the 15-minute requirement of the NCTS facility (noted earlier). 
Table 4.10. Summary of Implementation Costs

\begin{tabular}{|c|c|c|c|c|}
\hline Scenario & $\begin{array}{c}\text { Implementation } \\
\text { Cost } \\
(1993 \text { \$) } \\
\end{array}$ & $\begin{array}{c}\text { Replacement } \\
\text { Year }^{(2)} \\
\end{array}$ & $\begin{array}{c}\text { Replacement } \\
\text { Cost } \\
(1993 \text { S }) \\
\end{array}$ & $\begin{array}{l}\text { Economic Value at } \\
\text { End of LCC Period } \\
(\%) \\
\end{array}$ \\
\hline 1 & 0 & 2015 & $1,950,000$ & 81 \\
\hline 2 & 0 & $\mathrm{n} / \mathrm{a}$ & $n / a$ & 0 \\
\hline 3 & 0 & $\mathbf{n} / \mathbf{a}$ & $\mathbf{n} / \mathbf{a}$ & 0 \\
\hline 4 & 54,525 & $2005 \& 2019$ & $1,950,000$ & 89 \\
\hline 5 & 90,475 & 2017 & $1,950,000$ & 87 \\
\hline 6 & 90,475 & $\mathbf{n} / \mathbf{a}$ & $\mathbf{n} / \mathbf{a}$ & 0 \\
\hline 7 & $1,830,000$ & 2009 & $1,830,000$ & 18 \\
\hline 8 & $1,865,950$ & $\mathbf{n} / \mathbf{a}$ & $\mathbf{n} / \mathbf{a}$ & 0 \\
\hline 9 & $1,865,950$ & $\mathbf{n} / \mathbf{a}$ & $\mathrm{n} / \mathrm{a}$ & 0 \\
\hline 10 & $5,554,000$ & 2016 & $3,080,000$ & 78 \\
\hline 11 & $5,589,950$ & $\mathbf{n} / \mathbf{a}$ & $\mathbf{n} / \mathbf{a}$ & 17 \\
\hline 12 & $5,589,950$ & $\mathrm{n} / \mathbf{a}$ & $n / a$ & 17 \\
\hline 13 & 100,475 & $\mathbf{n} / \mathbf{a}$ & $\mathbf{n} / \mathbf{a}$ & 0 \\
\hline 14 & 259,250 & $\mathbf{n} / \mathbf{a}$ & $\mathbf{n} / \mathbf{a}$ & 0 \\
\hline 15 & $2,024,425$ & $\mathbf{n} / \mathbf{a}$ & $\mathbf{n} / \mathbf{a}$ & 0 \\
\hline 16 & 100,475 & $\mathrm{n} / \mathrm{a}$ & $\mathrm{n} / \mathrm{a}$ & 0 \\
\hline 17 & 100,475 & $\mathbf{n} / \mathbf{a}$ & $\mathbf{n} / \mathbf{a}$ & 0 \\
\hline 18 & 259,250 & $\mathbf{n} / \mathbf{a}$ & $\mathrm{n} / \mathrm{a}$ & 0 \\
\hline 19 & 259,250 & $\mathrm{n} / \mathrm{a}$ & $\mathrm{n} / \mathrm{a}$ & 0 \\
\hline
\end{tabular}

(a) Assumes implementation by end of 1995. 
Table 4.11. Summary of Life-Cycle Cost Analysis in 1995 Dollars

\begin{tabular}{|c|c|c|c|c|}
\hline Scenario & $\begin{array}{c}\text { Life-Cycle Cost } \\
\text { w/Emission } \\
\text { Credit (\$) } \\
\end{array}$ & $\begin{array}{l}\text { Life-Cycle Cost } \\
\text { w/o Emission } \\
\text { Credit (\$) }\end{array}$ & $\begin{array}{l}\text { Net Savings } \\
\text { w/Emission } \\
\text { Credit (\$) } \\
\end{array}$ & $\begin{array}{c}\text { Net Savings } \\
\text { w/o Emission } \\
\text { Credit (\$) } \\
\end{array}$ \\
\hline 1 & $12,522,000$ & $12,528,000$ & base case & base case \\
\hline 2 & $9,286,000$ & $9,509,000$ & $3,236,000$ & $3,019,000$ \\
\hline 3 & $8,322,000$ & $8,709,000$ & $4,200,000$ & $3,819,000$ \\
\hline 4 & $14,988,000$ & $15,012,000$ & $(2,466,000)$ & $(2,474,000)$ \\
\hline 5 & $10,073,000$ & $10,318,000$ & $2,449,000$ & $2,210,000$ \\
\hline 6 & $4,319,000$ & $4,709,050$ & $8,203,000$ & $7,819,000$ \\
\hline 7 & $13,897,000$ & $13,910,000$ & $(1,375,000)$ & $(1,382,000)$ \\
\hline 8 & $9,222,000$ & $9,467,000$ & $3,300,000$ & $3,061,000$ \\
\hline 9 & $5,417,000$ & $5,807,000$ & $7,105,000$ & $6,721,000$ \\
\hline 10 & $28,923,000$ & $28,936,000$ & $(16,401,000)$ & $(16,408,000)$ \\
\hline 11 & $16,099,000$ & $16,344,000$ & $(3,577,000)$ & $(3,816,000)$ \\
\hline 12 & $9,233,000$ & $9,621,000$ & $3,289,000$ & $2,907,000$ \\
\hline 13 & 898,000 & $1,342,000$ & $11,624,000$ & $11,186,000$ \\
\hline 14 & $1,069,000$ & $1,513,000$ & $11,453,000$ & $11,015,000$ \\
\hline 15 & $2,969,000$ & $3,413,000$ & $9,553,000$ & $9,115,000$ \\
\hline 16 & $(1,430,000)$ & $(989,000)$ & $13,952,000$ & $13,517,000$ \\
\hline 17 & $(2,560,000)$ & $(2,118,000)$ & $15,082,000$ & $14,646,000$ \\
\hline 18 & $(1,259,000)$ & $(818,000)$ & $13,781,000$ & $13,346,000$ \\
\hline 19 & $(2,389,000)$ & $(1,947,000)$ & $14,911,000$ & $14,475,000$ \\
\hline
\end{tabular}




\subsection{References}

10 CFR 436. 1990. U.S. Department of Energy, "Federal Energy Management and Planning Programs." U.S. Code of Federal Regulations.

California Energy Commission (CEC). 1991. Energy Technology Status Report, Appendix A Volume II: Detailed Electrical Generating Technology Evaluations. P500-90-003A, Sacramento, California.

Daellenbach, K. K., J. E. Dagle, S. A. Shankle, and R. W. Reilly. 1993. Economic Analysis of Operating Alternatives for the South Vandenberg Power Plant at Vandenberg Air Force Base, California. PNL-8556, Pacific Northwest Laboratory, Richland, Washington.

Dixon, D. R., P. R. Armstrong, K. K. Daellenbach, J. E. Dagle, F. V. DiMassa, D. B. Elliott, J. M. Keller, E. E. Richman, S. A. Shankle, G. P. Sullivan, and R. R. Wahlstrom. 1992. Fort Drum Integrated Resource Assessment, Volume 3: Resource Assessment. PNL-8424 Vol. 3, Pacific Northwest Laboratory, Richland, Washington.

Gerber, D. C. 1988. Small Scale Cogeneration System Cost and Performance. EPRI EM-5954, Electric Power Research Institute, Palo Alto, California.

Gifford, W. L. 1982. Cogeneration Feasibility Study Naval Regional Data Automation Center (NARDAC). Project No. P-261, Merle Strumm and Associates, San Diego, California.

Hay, N. E., ed. 1988. Guide to Natural Gas Cogeneration. Fairmont Press, Lilburn, Georgia.

National Bureau of Standards (NBS). 1987. Life-Cycle Costing Manual for the Federal Energy Management Program. NBS Handbook 135, U.S. Government Printing Office, Washington D.C.

National Institute of Standards and Technology (NIST). 1992. Energy Prices and Discount Factors for Life-Cycle Cost Analysis 1993. NIST Handbook 135, National Technical Information Service, Springfield, Virginia.

Richman, E. E., R. K. Hoshide, and A. L. Dittmer. 1993. David Grant Medical Center Energy Use Baseline and Integrated Resource Assessment. PNL-8647, Pacific Northwest Laboratory, Richland, Washington.

Rodden, R. M., J. L. Boyen, and M. H. Waters. 1986. Reference Guide to Small Cogeneration Systems for Utilities. EPRI EM-4371, Electric Power Research Institute, Palo Alto, California.

Zavala, C. F., and J. L. Heller. 1991. Cost Effectiveness of Cogeneration at Naval Regional Medical Center San Diego, California and Naval Regional Data Automation Center San Diego, California. NEESA 41-083, Naval Energy and Environmental Support Activity (NEESA), Port Hueneme, California. 
Appendix A

Public Works Center Meter Utility Reports for 1992 


\section{(*)}

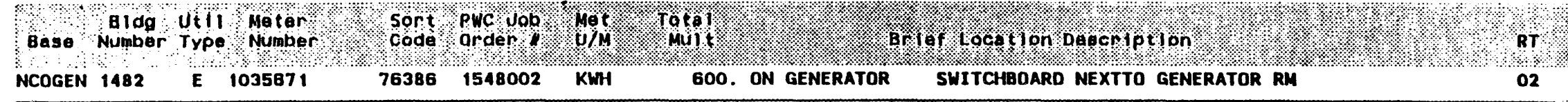

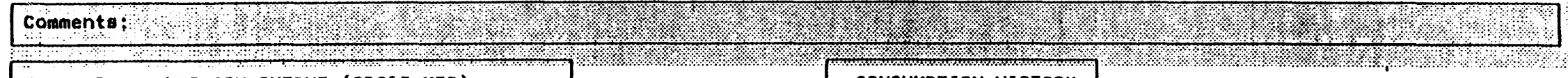

\section{Meter Feeds:TOT GEN OUTPUT (SDG\&E MIR)}

CONSUMPTION HISTORY

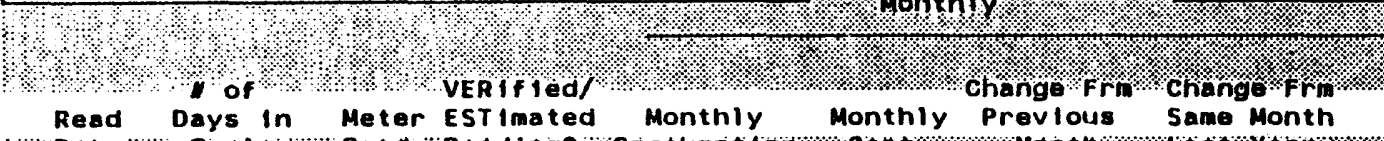

Read Days in
Date Cycie

$07-$ Aigg 90 - 29

07 sep 90,3

$09-0 c t-90 \quad 32$

$05-\mathrm{NaV}-90$
$05-\mathrm{DeG}-90$

$0 B-\operatorname{Jan} 9$ it 3

$\begin{array}{ll}06-\text { Feb-91 } & 29 \\ 08-M a r-91 & 30\end{array}$

O8-Mar-91 30

$08-$ May 9 i 30

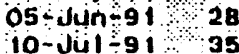

$\begin{array}{ll}\text { 10-Juil-91 } & 35 \\ 08 \text {-Aug-91 } & 29\end{array}$

$\begin{array}{lr}08 \text {-Aug-91 } & 29 \\ 12 \text {-Sep-91\% } & 35\end{array}$

o-oct-a1 28

O7-Nov-9/2 28

09-Jan-92 35

$06-F$ QD:92: 28

12 -Mar- 92,35

$09-A p r-\theta 2,28$

07-Nay -92 26

04-Jun-92 28

$09-$ - u $1-92 \div 35$

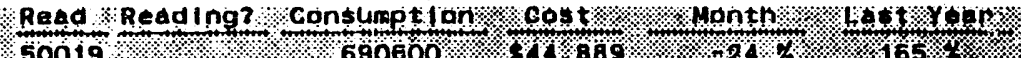

5oo19

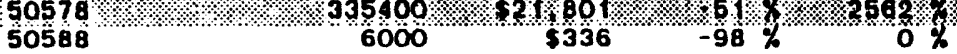

D

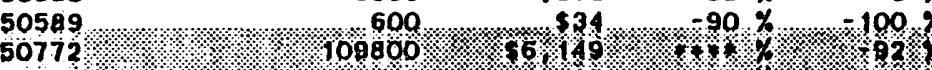

50772

80772 . 51513

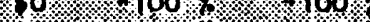

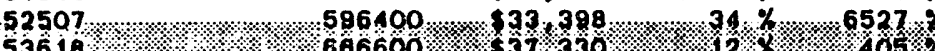

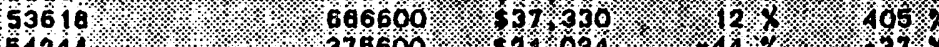

64244 $\begin{array}{lll}519000 & \$ 29.064 & -50 \%\end{array}$ . . . $13600 . \%$

60100

60736

60736

69345

648.1

66090

67320

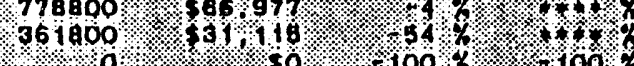
361900

381600

$\$ 32.818$

INFNT\%
INF

INFNT 738000 .....

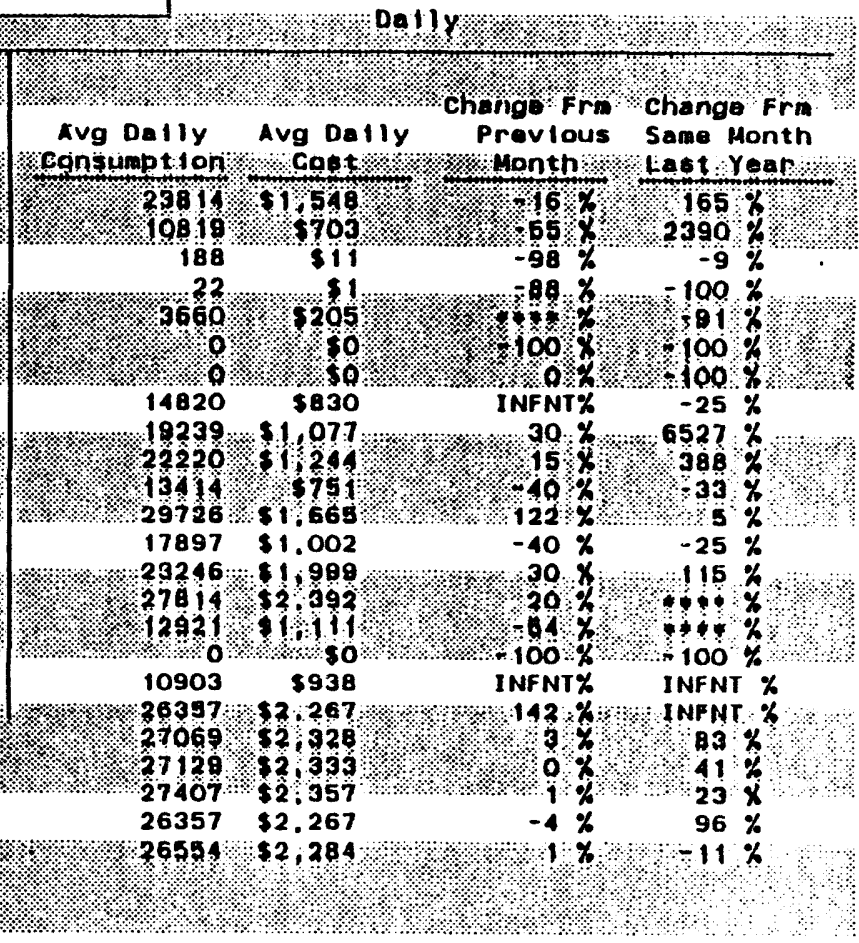




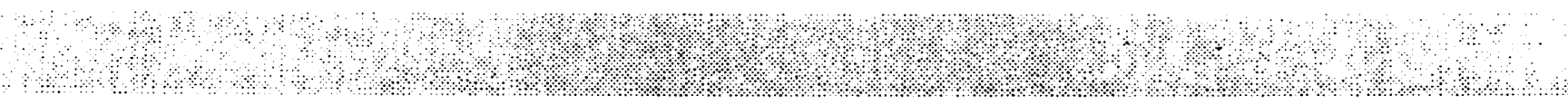

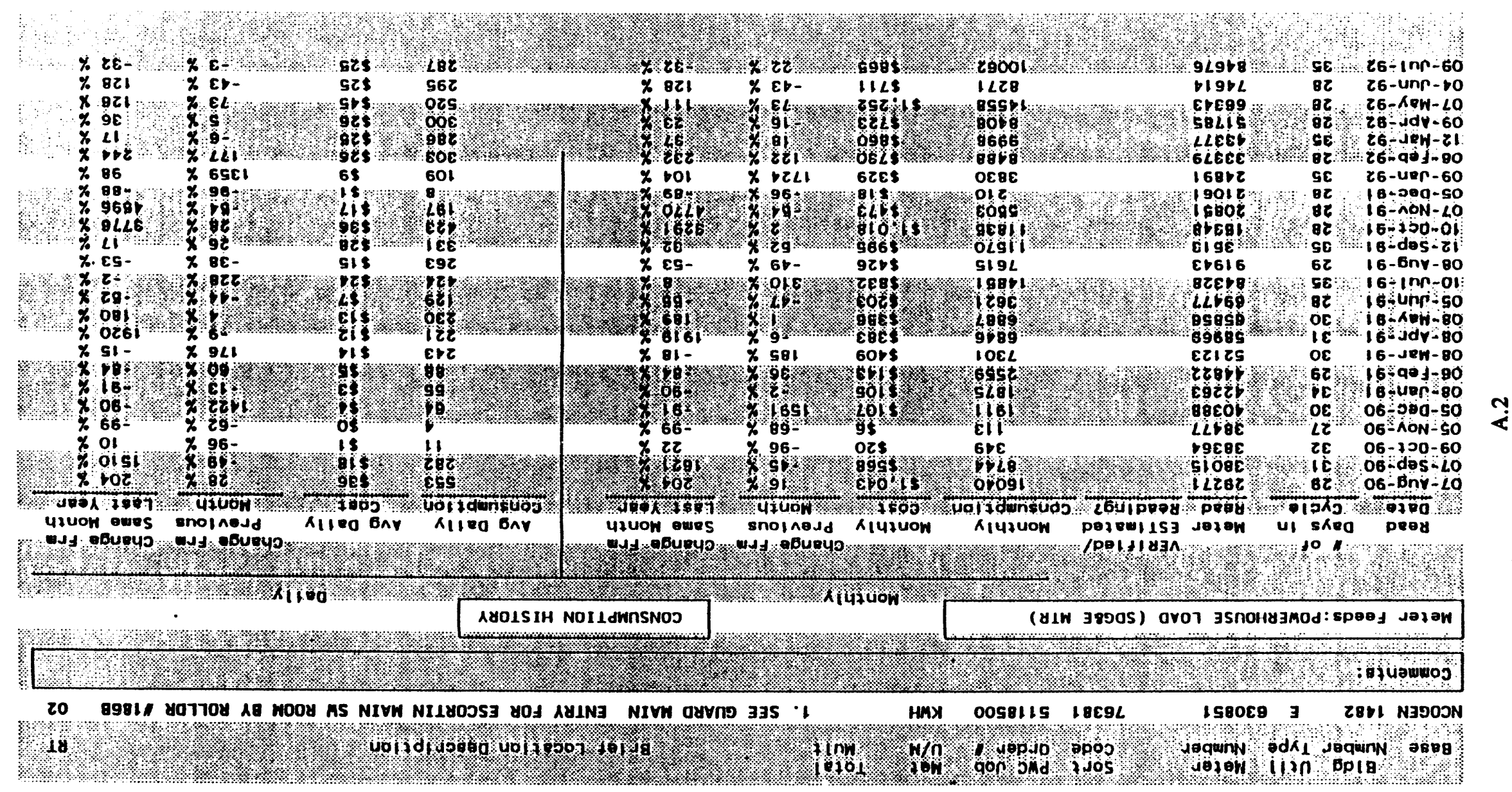

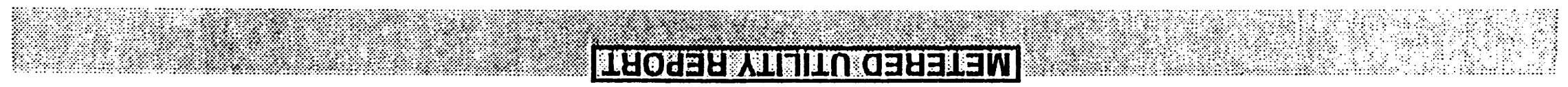
119 opos

dao sois

ofelo ues JMd : Ka pesedesd

$26-6 n v-z 0$

inoday jo olog 


\section{औ००}

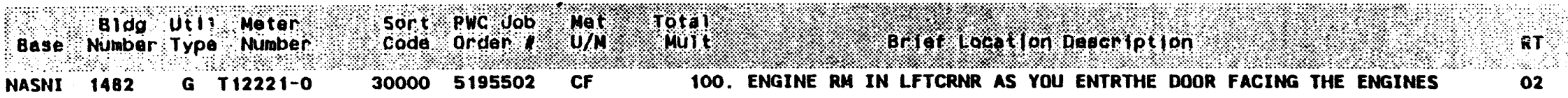

NASNI 1482

comments:

Meter Feeds:BLDG 1482 cogengas

$\longrightarrow$
.

1.7.

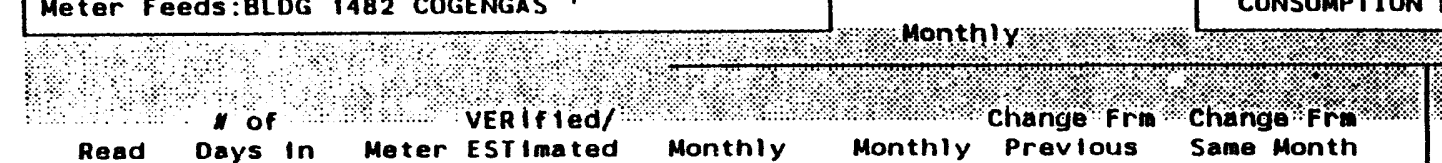

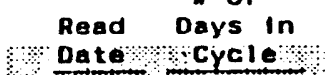

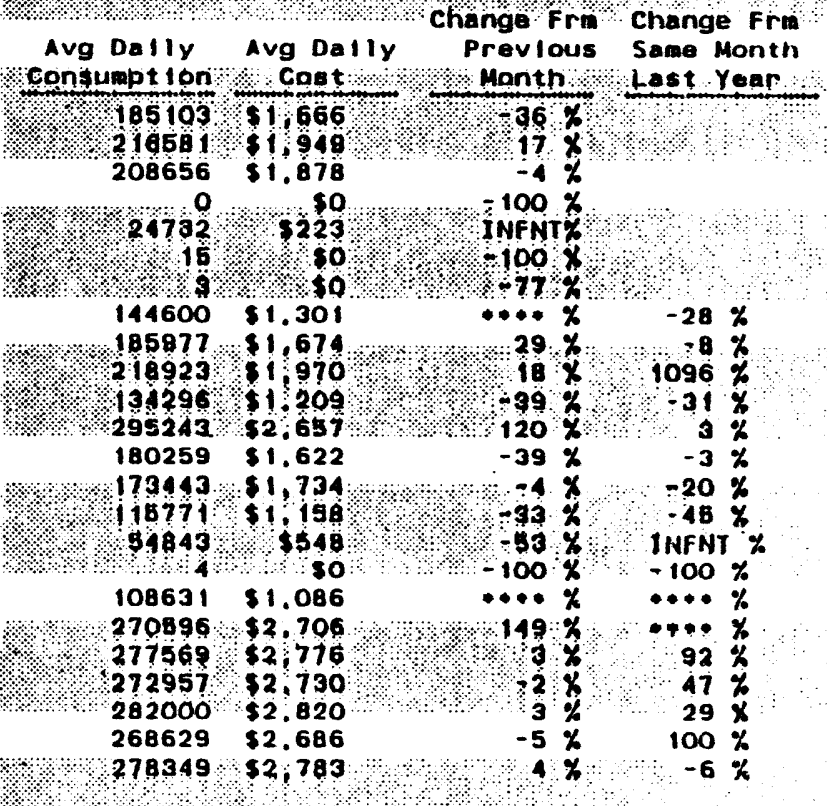

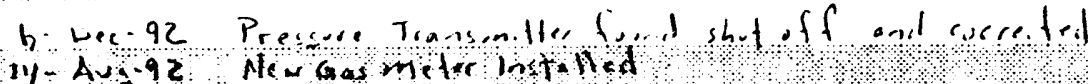




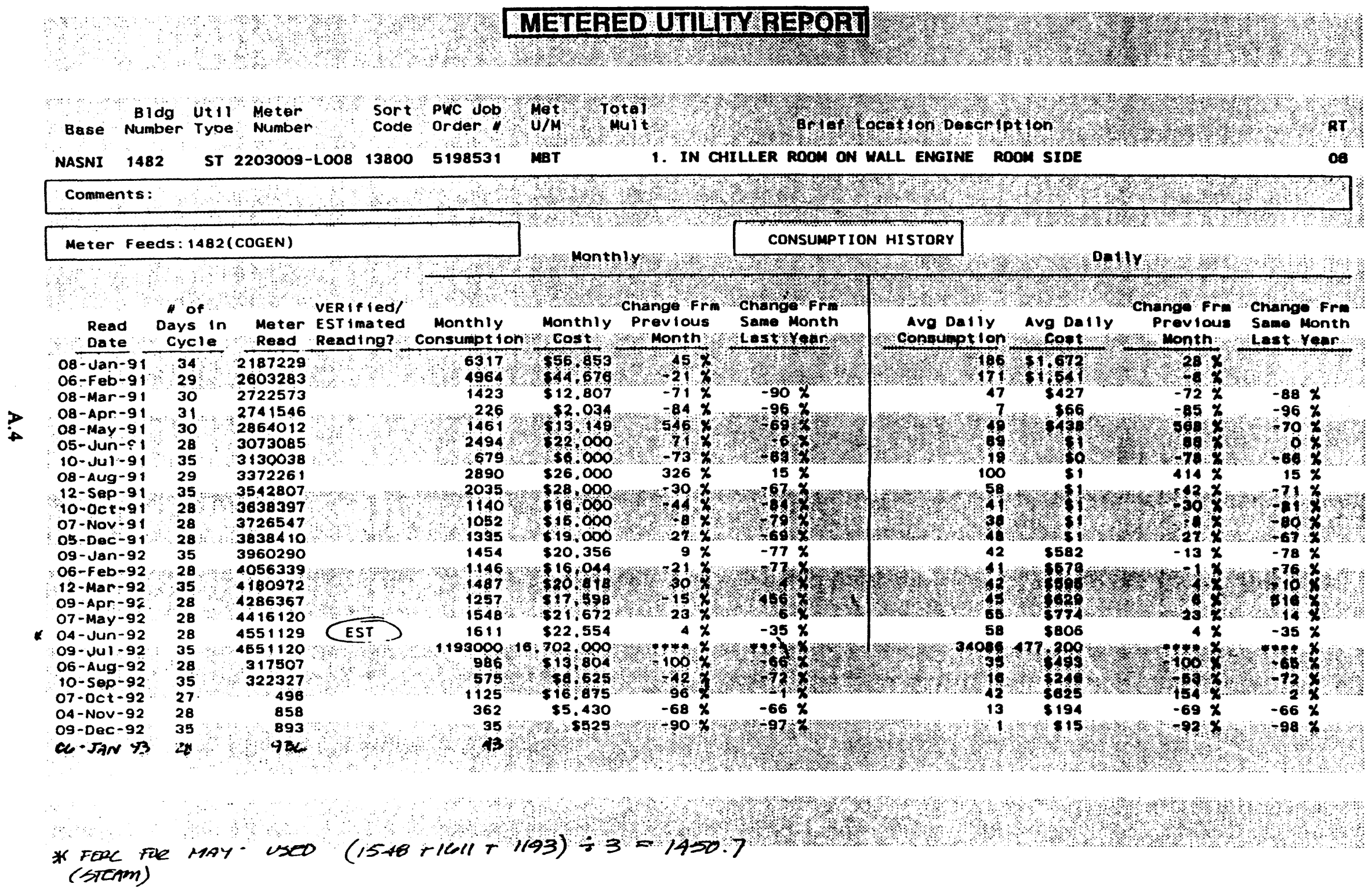




\section{Appendix B}

Natural-Gas Unit Cost Calculations for 1992 
Table B.1. Unit Cost Calculations for Natural Gas

\begin{tabular}{|c|c|c|c|c|c|}
\hline \multirow[b]{2}{*}{$\begin{array}{c}1992 \\
\text { Month }\end{array}$} & \multirow[b]{2}{*}{$\begin{array}{l}\text { Billing } \\
\text { Season }\end{array}$} & \multicolumn{2}{|c|}{ Cogen Rate } & \multicolumn{2}{|c|}{ Non-Cogen Rate } \\
\hline & & $\begin{array}{c}\text { Procurement } \\
\text { (\$/therm) }\end{array}$ & $\frac{\text { Transmission }}{\text { (\$/therm) }}$ & $\frac{\text { Procurement }}{(\$ / \text { therm) }}$ & $\frac{\text { Transmission }}{(\$ / \text { therm })}$ \\
\hline Jan & W & $\$ 0.215230$ & $\$ 0.120430$ & $\$ 0.215230$ & $\$ 0.177210$ \\
\hline Feb & W & $\$ 0.163980$ & $\$ 0.120430$ & $\$ 0.163980$ & $\$ 0.177210$ \\
\hline Mar & W & $\$ 0.163980$ & $\$ 0.119575$ & $\$ 0.163980$ & $\$ 0.176012$ \\
\hline Apr & $S$ & $\$ 0.163980$ & $\$ 0.095660$ & $\$ 0.163980$ & $\$ 0.142470$ \\
\hline May & $S$ & $\$ 0.174540$ & $\$ 0.096787$ & $\$ 0.174540$ & $\$ 0.144482$ \\
\hline Jun & $\mathbf{S}$ & $\$ 0.178865$ & $\$ 0.097520$ & $\$ 0.178865$ & $\$ 0.145790$ \\
\hline Jul & $\mathbf{S}$ & $\$ 0.169575$ & $\$ 0.097520$ & $\$ 0.169575$ & $\$ 0.145790$ \\
\hline Aug & $S$ & $\$ 0.215760$ & $\$ 0.097520$ & $\$ 0.215760$ & $\$ 0.145790$ \\
\hline Sep & $\mathbf{S}$ & $\$ 0.230600$ & $\$ 0.097520$ & $\$ 0.230600$ & $\$ 0.145790$ \\
\hline Oct & $\mathbf{S}$ & $\$ 0.272918$ & $\$ 0.097520$ & $\$ 0.272918$ & $\$ 0.145790$ \\
\hline Nov & $\mathbf{S}$ & $\$ 0.238458$ & $\$ 0.099173$ & $\$ 0.238458$ & $\$ 0.148116$ \\
\hline Dec & W & $\$ 0.204987$ & $\$ 0.124140$ & $\$ 0.204987$ & \$0.183245 \\
\hline \multicolumn{6}{|l|}{ Average: } \\
\hline Winter & & $\$ 0.18704$ & $\$ 0.12114$ & $\$ 0.18704$ & $\$ 0.17842$ \\
\hline \multirow[t]{12}{*}{ Summer } & & $\$ 0.20559$ & $\$ 0.09740$ & $\$ 0.20559$ & $\$ 0.14550$ \\
\hline & & & Summer & Winter & \\
\hline & & Cogen Rate: & & & \\
\hline & & Procurement & $\$ 0.20559$ & $\$ 0.18704$ & \\
\hline & & Transmission & $\$ 0.09740$ & $\$ 0.12114$ & \\
\hline & & Reg. Fee & $\$ 0.00076$ & $\$ 0.00076$ & \\
\hline & & Total & $\$ 0.30375$ & $\$ 0.30895$ & /therm \\
\hline & & Non-Cogen Rate: & & & \\
\hline & & Procurement & $\$ 0.20559$ & $\$ 0.18704$ & \\
\hline & & Transmission & $\$ 0.14550$ & $\$ 0.17842$ & \\
\hline & & Reg. Fee & $\$ 0.00076$ & $\$ 0.00076$ & \\
\hline & & Total & $\$ 0.35185$ & $\$ 0.36622$ & /therm \\
\hline
\end{tabular}

B.1 


\section{Appendix C}

Public Works Center Federal Energy Regulatory Commission Calculations for 1992 
COGBWERATION DAM SOMARY

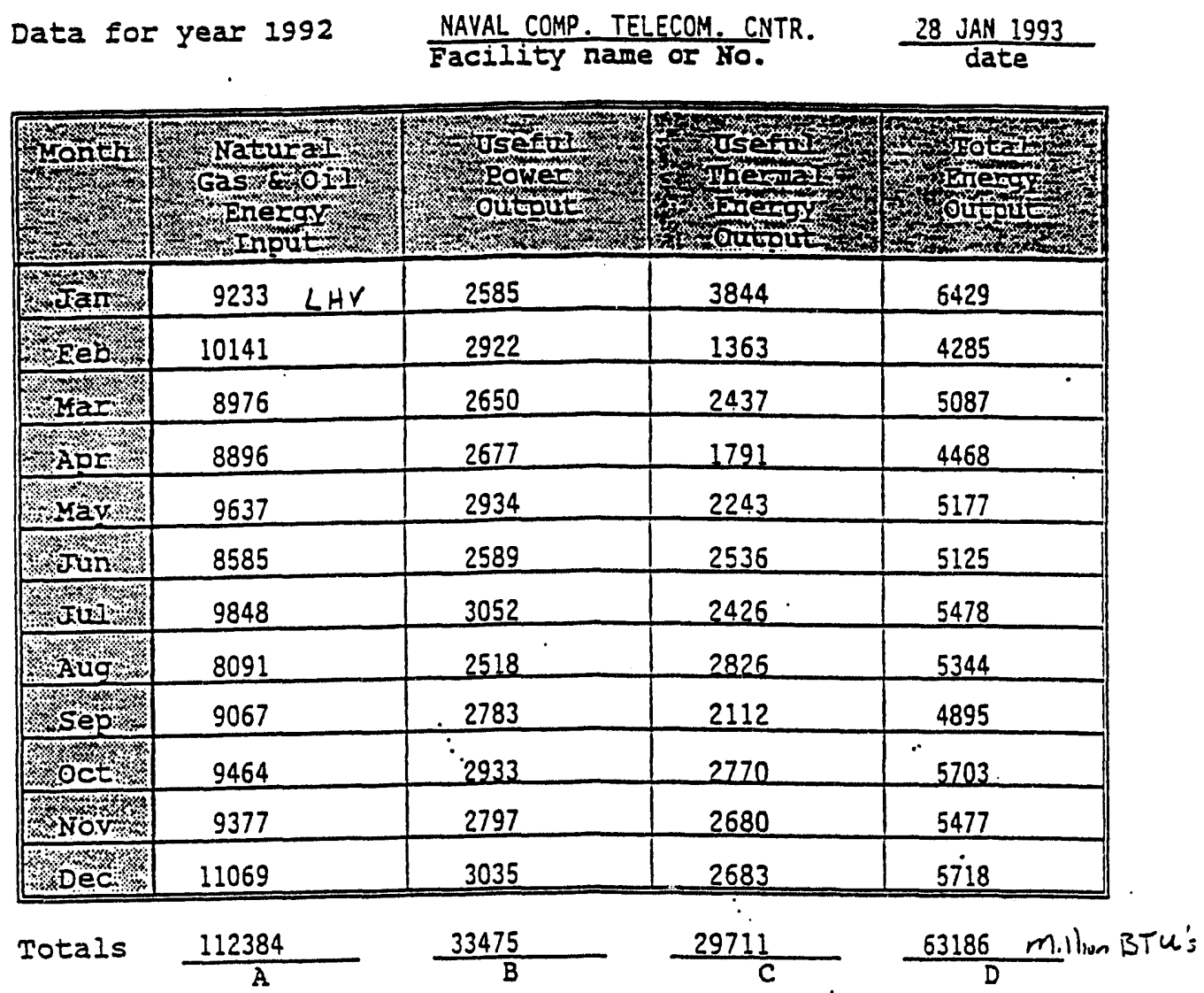

The operating and efficiency standards in equation form are:
1. operating standard
2. efficiency standard
$\frac{C}{D} \times 1008258$

$$
\left(\frac{B+\frac{C}{2}}{A}\right) \times 1008242.5
$$

My operating standard result is

47.0\%

My efficiency standard result is

for PWC San Diego, CA signature entity

signature
$\frac{\text { Head, Utilities Department }}{\text { title }}$
Relationship to the cogeneration facility owner
Head, Utilities Department

C. 1 
Appendix D

Marginal Energy Cost Calculations - Cogen Gas Rate 


\section{Marginal Energy Cost Analysis - Cogen Gas Rate}

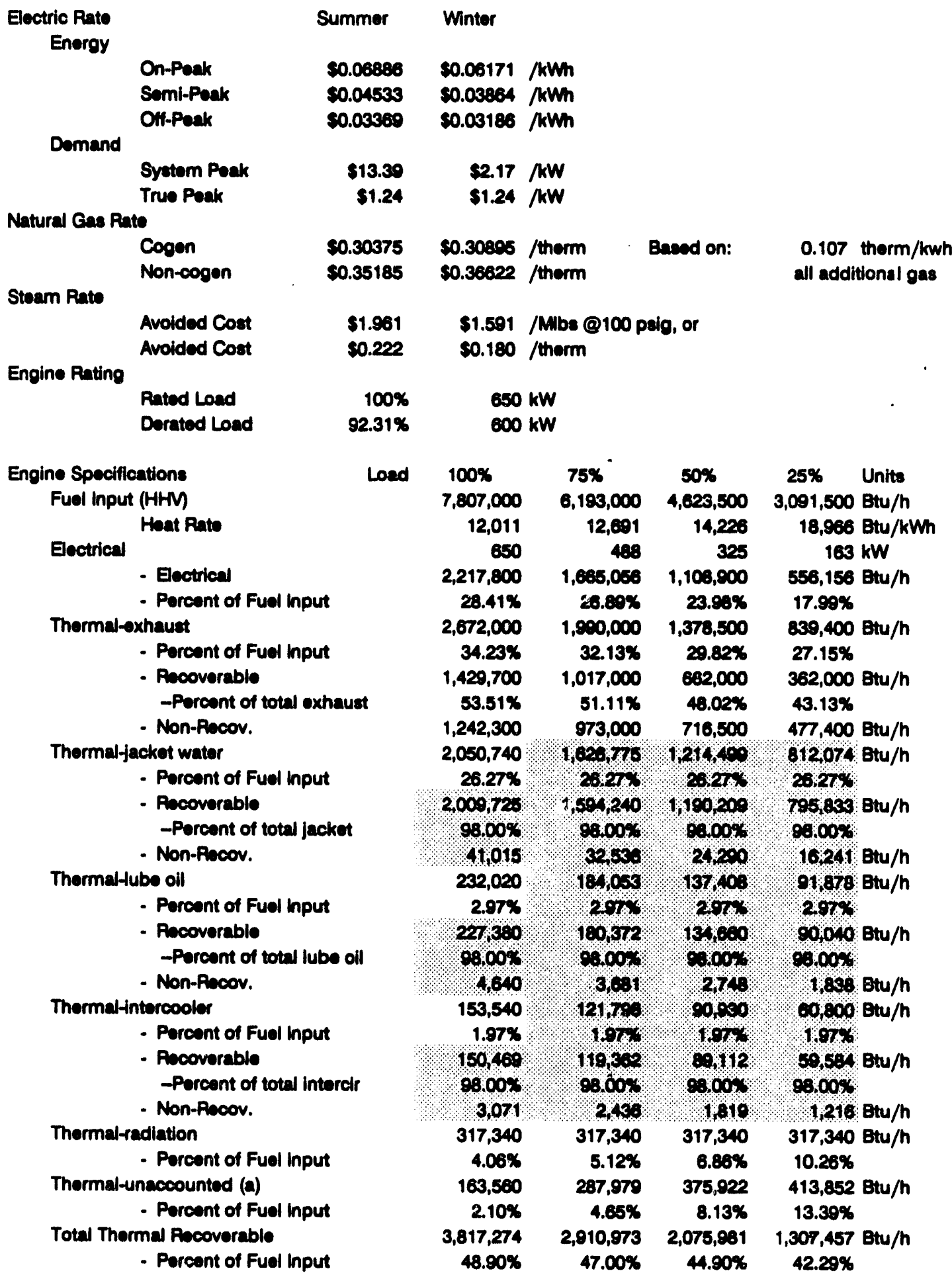

(a) Unaccounted thermal energy moet likely in the jacket water and lube oll heat syatem. Shaded area not documented in equipment specifications, aseumed values.

D.1 


\section{Efficiency Analysis}

\begin{tabular}{|c|c|c|c|c|c|}
\hline $\begin{array}{l}\text { Efficiency (based on HHV of fuel) } \\
\text { Electrieal } \\
\text { Thermal Recoverablo } \\
\text { Total Cogen Efficioncy }\end{array}$ & Load & $\begin{array}{l}100 \% \\
28.41 \% \\
48.90 \% \\
77.30 \%\end{array}$ & $\begin{array}{l}75 \% \\
28.60 \% \\
47.00 \% \\
73.80 \%\end{array}$ & $\begin{array}{l}50 \% \\
23.98 \% \\
44.90 \% \\
68.88 \%\end{array}$ & $\begin{array}{l}25 \% \\
17.99 \% \\
42.29 \% \\
60.28 \%\end{array}$ \\
\hline $\begin{array}{l}\text { Efficiency (based on LHV of full) } \\
\text { Not Eloctrical } \\
\text { Thermal Rocoverable } \\
\text { Total Cogen Efficiency }\end{array}$ & Load & $\begin{array}{l}100 \% \\
30.31 \% \\
54.33 \% \\
84.64 \%\end{array}$ & $\begin{array}{l}75 \% \\
28.62 \% \\
52.23 \% \\
80.85 \%\end{array}$ & $\begin{array}{l}50 \% \\
25.40 \% \\
49.80 \% \\
75.29 \%\end{array}$ & $\begin{array}{l}25 \% \\
18.74 \% \\
46.99 \% \\
65.73 \%\end{array}$ \\
\hline $\begin{array}{l}\text { ERC Efficioncy (a) } \\
\text { Thermal energy uasable } \\
\text { (percent of recoverable) }\end{array}$ & $\begin{array}{r}100 \% \\
80 \% \\
80 \% \\
75 \% \\
70 \% \\
60 \% \\
50 \% \\
40 \%\end{array}$ & $\begin{array}{l}57.48 \% \\
54.76 \% \\
52.05 \% \\
50.69 \% \\
49.33 \% \\
46.61 \% \\
43.90 \%\end{array}$ & $\begin{array}{l}54.74 \% \\
52.13 \% \\
40.51 \% \\
48.21 \% \\
46.90 \% \\
44.20 \% \\
5.8\end{array}$ & $\begin{array}{l}50.34 \% \\
47.85 \% \\
45.35 \% \\
44.11 \% \\
42.86 \% \\
\end{array}$ & 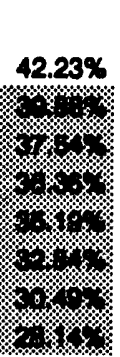 \\
\hline
\end{tabular}

(a) Shaded area does not meot SDGEE officiency requirements as a Qualified Facility (QF). FERC efficiency = not electrical officiency $+1 / 2$ useful thermal efficiency FEAC calculations based on fuel lower heating value (LH). 
Value of Cogenerated Energy

Engine Full Load

Nalues are per engine per hour)

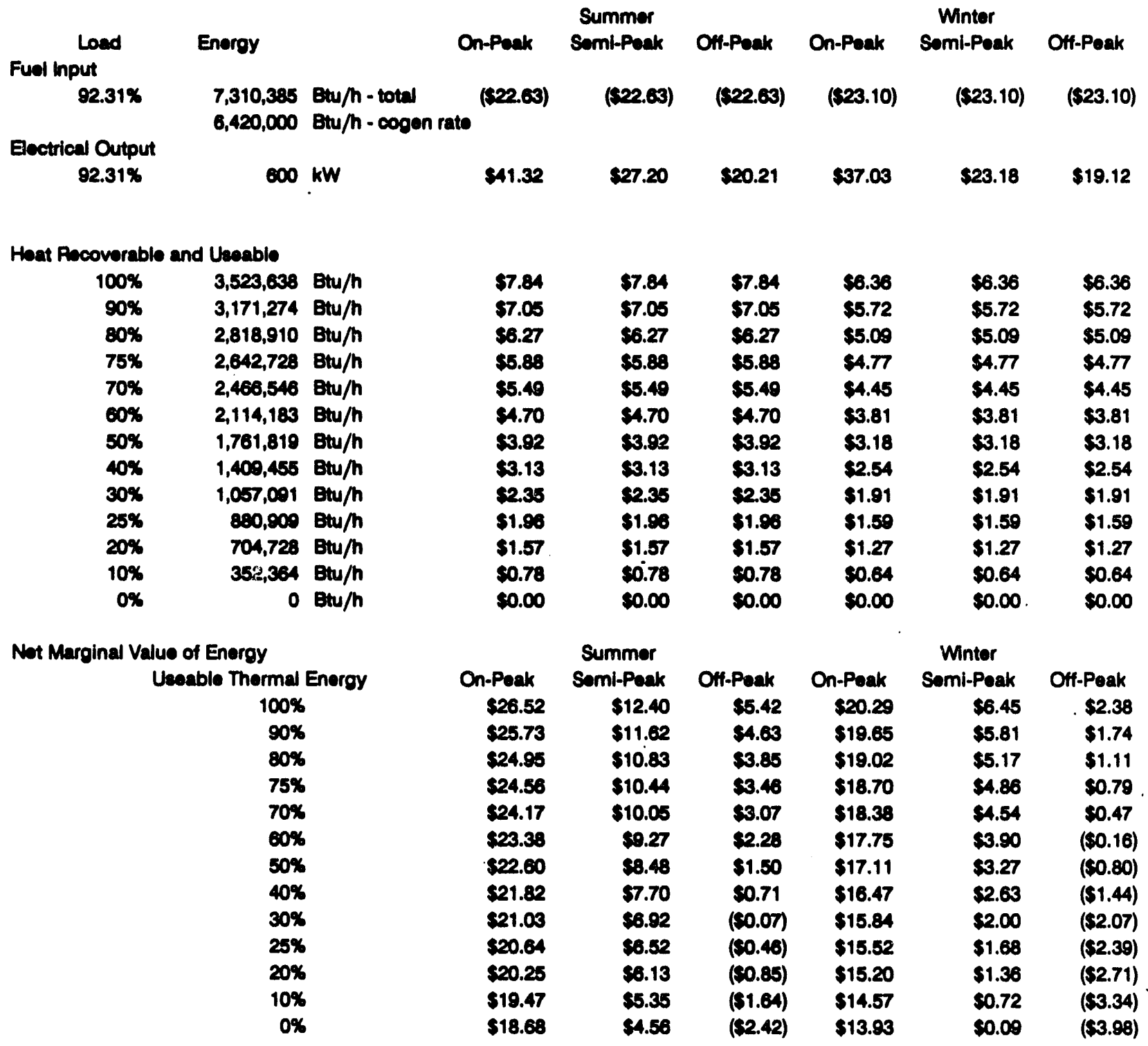


Value of Cogenerated Energy

Thermal Load Following

Naluos are per engine per hour)

\begin{tabular}{|c|c|c|}
\hline $\begin{array}{l}\text { Load } \\
\text { Fuel input }\end{array}$ & Energy & \\
\hline $92 \%$ & $7,310,534$ & Btw/h \\
\hline $90 \%$ & $7,161,400$ & Btu/h \\
\hline $80 \%$ & $6,515,800$ & Btu/h \\
\hline $75 \%$ & $6,193,000$ & Btw/h \\
\hline $70 \%$ & $5,879,100$ & Btu/h \\
\hline $60 \%$ & $5,251,300$ & $B t u / h$ \\
\hline $50 \%$ & $4,623,500$ & Btu/h \\
\hline $40 \%$ & $4,010,700$ & Btu/h \\
\hline $30 \%$ & $3,397,000$ & Btu/h \\
\hline $25 \%$ & $3,091,500$ & Btu/h \\
\hline
\end{tabular}

Hoat Riscoverable and Usoable

$\begin{array}{lll}92 \% & 3,538,498 & \text { Btu/h } \\ 90 \% & 3,454,754 & \text { Btu/h } \\ 80 \% & 3,002,233 & \text { Btu/h } \\ 75 \% & 2,910,973 & \text { Btu/h } \\ 70 \% & 2,743,974 & \text { Btu/h } \\ 60 \% & 2,400,978 \text { Btu/h } \\ 50 \% & 2,075,981 \text { Btu/h } \\ 40 \% & 1,768,571 \text { Btu/h } \\ 30 \% & 1,461,162 \text { Btu/h } \\ 25 \% & 1,307,457 \text { Btu/h }\end{array}$

Electrical Output

$\begin{array}{ll}92 \% & 600 \mathrm{~kW} \\ 90 \% & 585 \mathrm{~kW} \\ 80 \% & 520 \mathrm{~kW} \\ 75 \% & 488 \mathrm{~kW} \\ 70 \% & 456 \mathrm{~kW} \\ 60 \% & 390 \mathrm{~kW} \\ 50 \% & 325 \mathrm{~kW} \\ 40 \% & 280 \mathrm{~kW} \\ 30 \% & 196 \mathrm{~kW} \\ 25 \% & 163 \mathrm{~kW}\end{array}$

Not Marginal Value of Energy

\begin{tabular}{|c|c|c|c|c|c|}
\hline n-Poak & $\begin{array}{l}\text { Summer } \\
\text { Somi-Paak }\end{array}$ & OH-Paak & On-Poak & $\begin{array}{l}\text { Winter } \\
\text { Somi-Poak }\end{array}$ & Off-Poak \\
\hline$(\$ 22.63)$ & $(\$ 22.60)$ & (122.63) & $(+23.09)$ & $(\$ 23.09)$ & $(\$ 23.09)$ \\
\hline$(\$ 22.19)$ & (122.10) & $(02.19)$ & $(322.64)$ & $(\$ 22.64)$ & (\$22.64) \\
\hline (\$20.25) & $(120.25)$ & $(120.25)$ & $(\$ 20.67)$ & $(\$ 20.67)$ & $(\$ 20.67)$ \\
\hline$(\$ 19.28)$ & (\$19.28) & (\$19.28) & $(\$ 19.69)$ & $(\$ 19.69)$ & $(\$ 19.69)$ \\
\hline (\$\$18.34) & (\$18.34) & $(\$ 18.34)$ & $(\$ 18.74)$ & $(\$ 18.74)$ & $(\$ 18.74)$ \\
\hline$(\$ 16.47)$ & $(\$ 18.47)$ & $(\$ 16.47)$ & $(\$ 16.84)$ & $(\$ 16.84)$ & $(\$ 16.84)$ \\
\hline$(\$ 14.60)$ & $(\$ 14.60)$ & $(\$ 14.60)$ & (\$14.84) & $(\$ 14.94)$ & $(\$ 14.94)$ \\
\hline (\$12.77) & $(\$ 12.77)$ & (\$12.77) & (\$13.09) & $(\$ 13.09)$ & $(\$ 13.09)$ \\
\hline (\$10.85) & $(\$ 10.05)$ & (\$10.85) & $(\$ 11.25)$ & $(\$ 11.25)$ & (\$11.25) \\
\hline$(\$ 10.04)$ & (\$10.04) & (\$10.04) & (\$10.32) & $(\$ 10.32)$ & $(\$ 10.32)$ \\
\hline
\end{tabular}

\begin{tabular}{|c|c|c|c|c|c|}
\hline$\$ 7.87$ & $\$ 7.87$ & $\$ 7.87$ & $\$ 6.38$ & $\$ 6.38$ & $\$ 6.38$ \\
\hline$\$ 7.68$ & $\$ 7.68$ & $\$ 7.68$ & $\$ 6.23$ & $\$ 6.23$ & $\$ 6.23$ \\
\hline$\$ 6.88$ & $\$ 6.88$ & 86.88 & $\$ 5.58$ & $\$ 5.58$ & $\$ 5.58$ \\
\hline$\$ 0.47$ & \$8.47 & $\$ 8.47$ & 55.25 & $\$ 5.25$ & $\$ 5.25$ \\
\hline$\$ 8.10$ & \$. 10 & \$6.10 & S4.85 & $\$ 4.95$ & $\$ 4.95$ \\
\hline s5.36 & \$5.38 & s5.38 & 84.36 & $\$ 4.35$ & $\$ 4.35$ \\
\hline$\$ 4.62$ & 84.62 & $\$ 4.62$ & $\$ 3.75$ & $\$ 3.75$ & \$3.75 \\
\hline$\$ 3.93$ & $\$ 3.93$ & $\$ 3.93$ & $\$ 3.19$ & $\$ 3.19$ & $\$ 3.19$ \\
\hline$\$ 3.25$ & $\$ 3.25$ & $\$ 3.25$ & $\$ 2.64$ & $\$ 2.64$ & $\$ 2.64$ \\
\hline$\$ 2.91$ & $\$ 2.91$ & $\$ 2.91$ & $\$ 2.36$ & $\$ 2.36$ & $\$ 2.36$ \\
\hline
\end{tabular}

$\begin{array}{lll}\$ 41.33 & \$ 27.21 & \$ 20.22 \\ \$ 40.30 & \$ 26.53 & \$ 19.72 \\ \$ 35.83 & \$ 23.59 & \$ 17.53 \\ \$ 33.60 & \$ 22.12 & \$ 16.44 \\ \$ 31.30 & \$ 20.64 & \$ 15.34 \\ \$ 26.87 & \$ 17.69 & \$ 13.15 \\ \$ 22.38 & \$ 14.73 & \$ 10.85 \\ \$ 17.92 & \$ 11.79 & \$ 8.77 \\ \$ 13.46 & \$ 8.80 & \$ 6.58 \\ \$ 11.22 & \$ 7.39 & \$ 5.49\end{array}$

$\$ 37.04$

\$36.11

$\$ 32.11$

$\$ \$ 0.11$

$\$ 28.10$

$\$ 24.08$

$\$ 20.06$

$\$ 16.08$

$\$ 12.00$

$\$ 10.08$

$\$ 23.19$

522.61

$\$ 20.11$

$\$ 18.88$

$\$ 17.60$

$\$ 15.08$

$\$ 12.56$

$\$ 10.05$

$\$ 7.55$

$\$ 6.30$

$\$ 19.12$

$\$ 18.64$

$\$ 16.58$

$\$ 15.55$

$\$ 14.51$

$\$ 12.43$

$\$ 10.35$

$\$ 8.20$

$\$ 6.23$

$\$ 5.10$

$\begin{array}{rr}\$ 26.50 & \$ 12.44 \\ \$ 25.79 & \$ 12.02 \\ \$ 22.46 & \$ 10.22 \\ \$ 20.80 & \$ 9.32 \\ \$ 19.12 & \$ 8.40 \\ \$ 15.76 & \$ 6.58 \\ \$ 12.40 & \$ 4.75 \\ \$ 9.08 & \$ 2.96 \\ \$ 5.75 & \$ 1.16 \\ \$ 4.09 & \$ 0.28\end{array}$

$\$ 5.46$
$\$ 5.21$
$\$ 4.16$
$\$ 3.64$
$\$ 3.10$
$\$ 2.04$
$\$ 0.97$
$(\$ 0.07)$
$(\$ 1.12)$
$(\$ 1.64)$

$\$ 20.33$

$\$ 19.71$

$\$ 17.02$

$\$ 15.68$

$\$ 14.31$

$\$ 11.69$

$\$ 8.86$

$\$ 6.15$

$\$ 3.45$

$\$ 2.00$ 


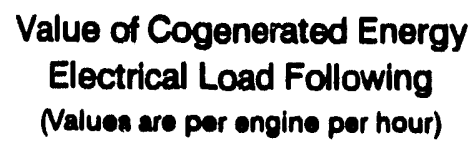

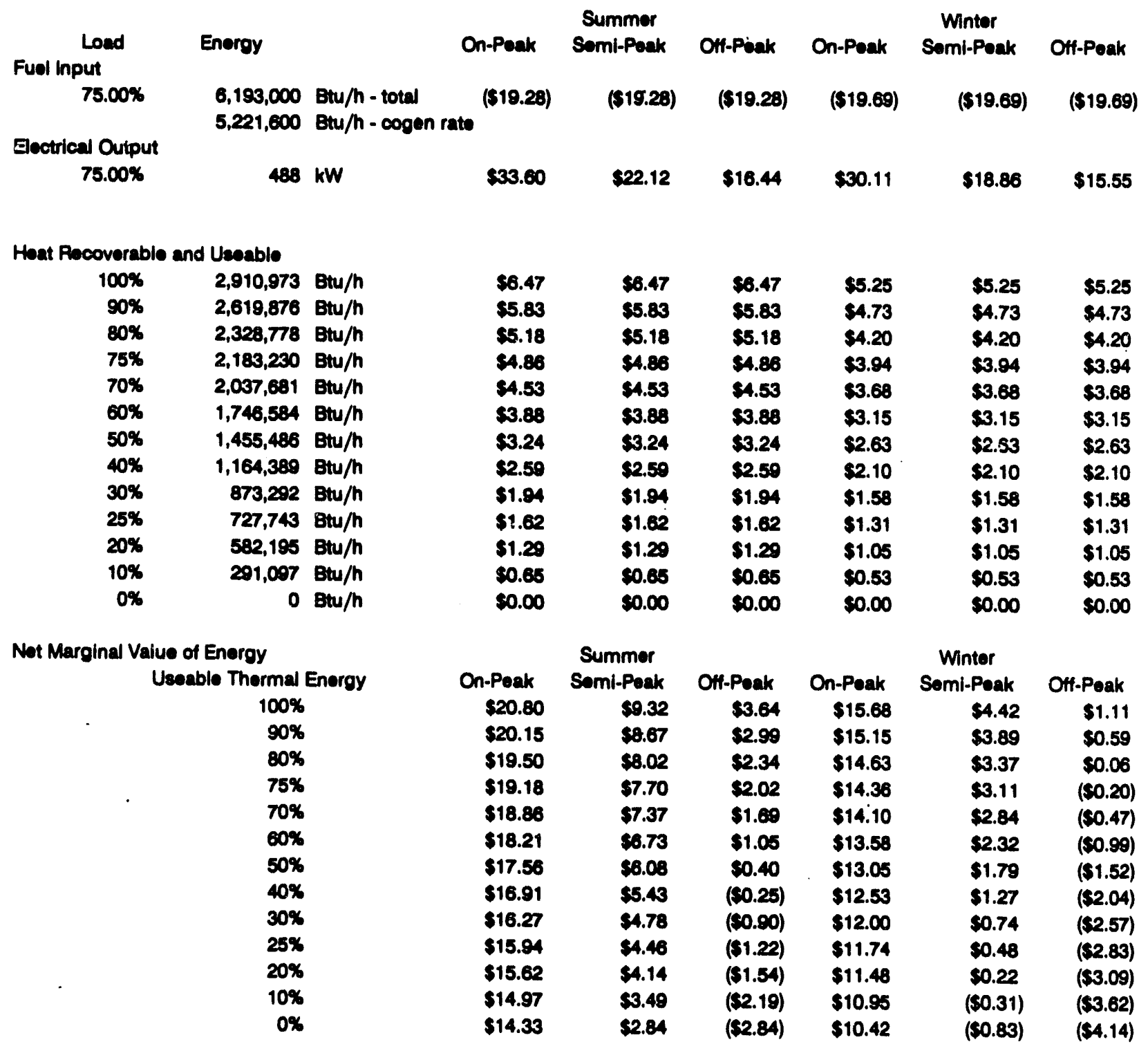


Value of Cogenerated Energy

Electrical Load Following

Nalues are per engine per hour)

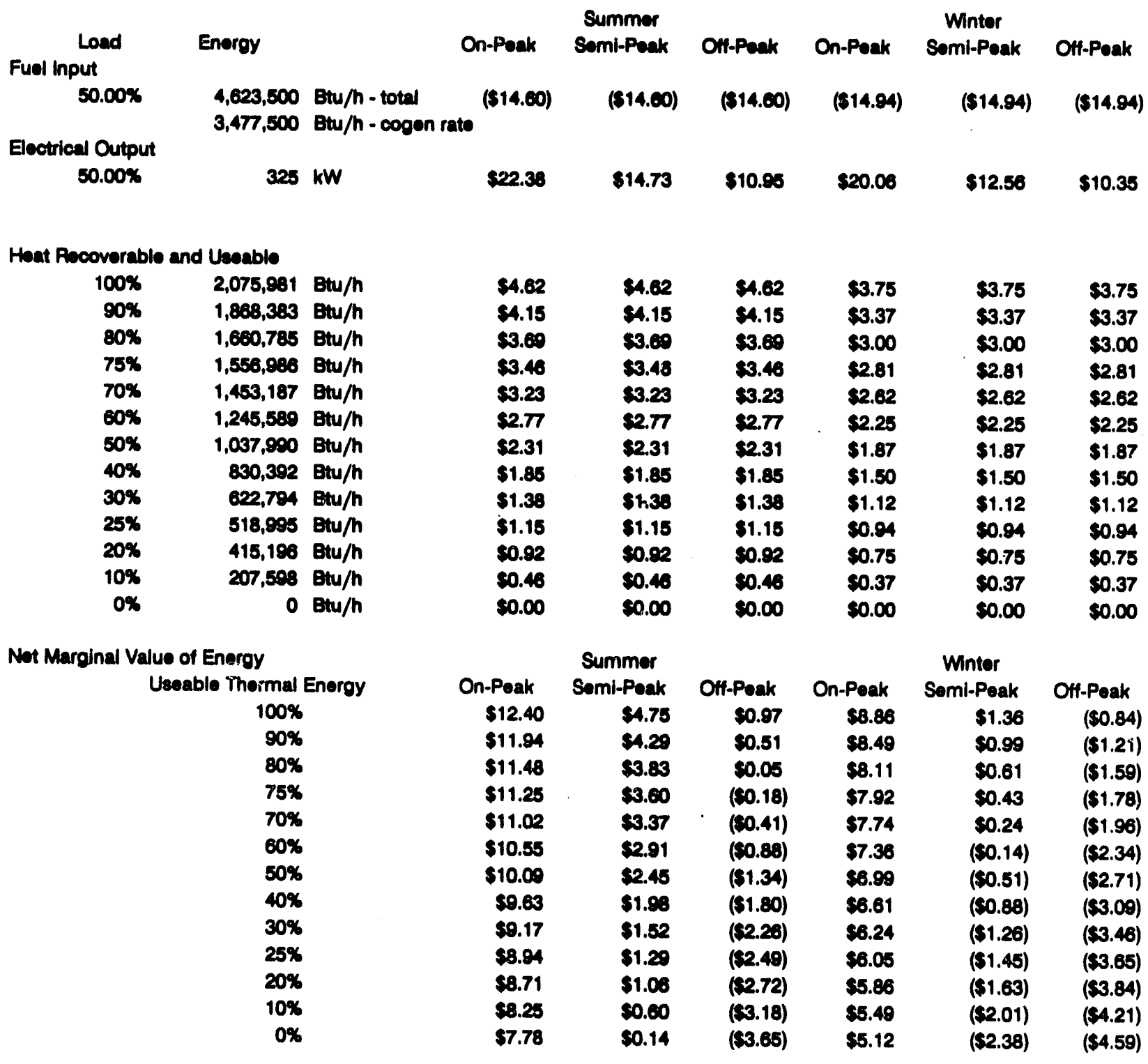

D.6 
Appendix E

Marginal Energy Cost Calculations - Non-Cogen Gas Rate 


\section{Marginal Energy Cost Analysis - Non-Cogen Gas Rate}

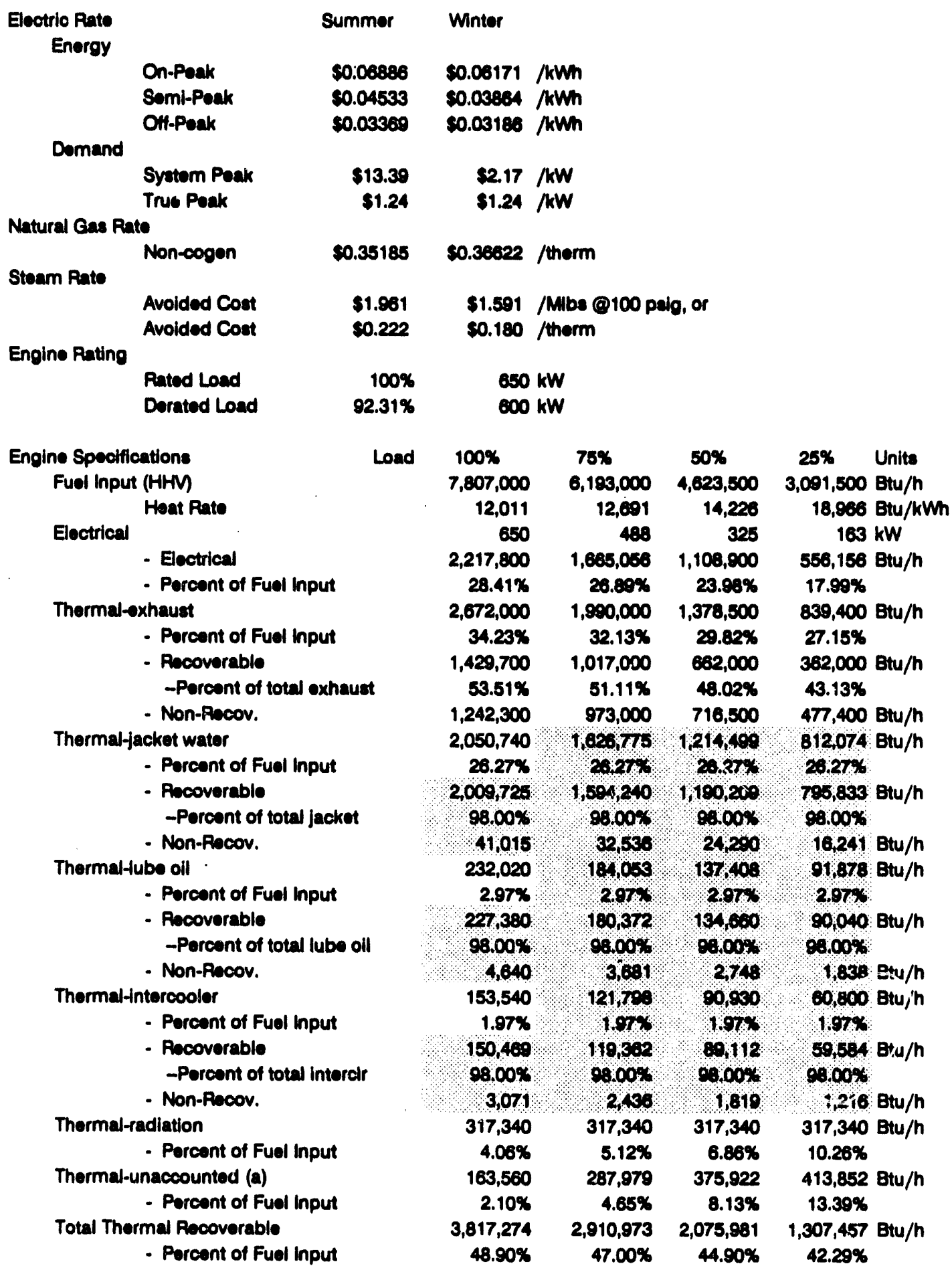

(a) Unaccounted thermal enorgy most likely in the jacket water and lube oll heat syatem. Shaded area not documented in equipment specifications, thorefore aseumed values.

E.1 


\section{Efficiency Analysis}

\begin{tabular}{|c|c|c|c|c|c|}
\hline $\begin{array}{l}\text { Etfiolenoy (based on HHV of tuel) } \\
\text { Electrioal } \\
\text { Thermal Ascoverable } \\
\text { Total Cogen Etfiolenoy }\end{array}$ & Load & $\begin{array}{l}100 \% \\
28.41 \% \\
48.00 \% \\
77.30 \%\end{array}$ & $\begin{array}{l}78 \% \\
28.60 \% \\
47.00 \% \\
73.80 \%\end{array}$ & $\begin{array}{l}50 \% \\
23.90 \% \\
4.00 \% \\
68.88 \%\end{array}$ & $\begin{array}{l}25 \% \\
17.99 \% \\
42.20 \% \\
60.28 \%\end{array}$ \\
\hline $\begin{array}{l}\text { Efficionoy (besed on LHV of fuel) } \\
\text { Not Electrioal } \\
\text { Thermal Rocoverable } \\
\text { Total Cogen Efflcionoy }\end{array}$ & Losd & $\begin{array}{l}100 \% \\
30.31 \% \\
54.33 \% \\
84.64 \%\end{array}$ & $\begin{array}{l}75 \% \\
28.62 \% \\
52.23 \% \\
80.86 \%\end{array}$ & $\begin{array}{l}50 \% \\
20.40 \% \\
40.80 \% \\
75.29 \%\end{array}$ & $\begin{array}{l}23 \% \\
18.74 \% \\
46.99 \% \\
65.73 \%\end{array}$ \\
\hline $\begin{array}{l}\text { FERC Efficiency (a) } \\
\text { Thermal on orgy ueable } \\
\text { (percent of recoverable) }\end{array}$ & $\begin{array}{l}100 \% \\
50 \% \\
80 \% \\
75 \% \\
70 \% \\
60 \% \\
50 \% \\
40 \%\end{array}$ & $\begin{array}{l}57.46 \% \\
54.76 \% \\
52.05 \% \\
50.69 \% \\
40.33 \% \\
46.61 \% \\
43.90 \% \\
5 \%\end{array}$ & $\begin{array}{l}54.74 \% \\
52.13 \% \\
49.51 \% \\
48.21 \% \\
46.00 \% \\
44.29 \% \\
.8 \% \\
x\end{array}$ & 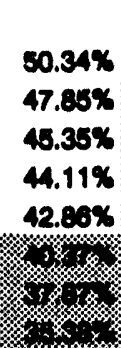 & 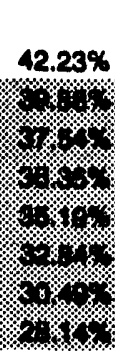 \\
\hline
\end{tabular}

(a) Shaded area does not meet SDG\&E officionoy requirements as a Quallified Faollity (OF). FERC officienoy = not electrical officionoy $+1 / 2$ usoful thermal officienoy Caloulations based on fuel lower heating value (LHM). 
Value of Cogenerated Energy

Engine Full Load

Nalues are per engine per hour)

Fuel input

Enorgy

92.31\% 7,310,386 Btu/h

Electrical Output

$92.31 \%$

$600 \mathrm{~kW}$

Hoat Rocoverable and Uacable

$\begin{array}{rrr}100 \% & 3,523,638 \mathrm{Btu} / \mathrm{h} \\ 50 \% & 3,171,274 \mathrm{Btu} / \mathrm{h} \\ 80 \% & 2,818,910 \mathrm{Btw} / \mathrm{h} \\ 75 \% & 2,642,728 \mathrm{Btu} / \mathrm{h} \\ 70 \% & 2,466,548 \mathrm{Btu} / \mathrm{h} \\ 60 \% & 2,114,183 \mathrm{Btu} / \mathrm{h} \\ 50 \% & 1,761,818 \mathrm{Btu} / \mathrm{h} \\ 40 \% & 1,409,468 \mathrm{Btu} / \mathrm{h} \\ 30 \% & 1,057,091 \mathrm{Btu} / \mathrm{h} \\ 20 \% & 880,900 \mathrm{Btu} / \mathrm{h} \\ 20 \% & 704,728 \mathrm{Btu} / \mathrm{h} \\ 10 \% & 362,364 \mathrm{Btu} / \mathrm{h} \\ 0 \% & 0 \mathrm{Btu} / \mathrm{h}\end{array}$

Not Marginal Value of Energy

Uneable Thermal Energy

$100 \%$

$90 \%$

$80 \%$

$75 \%$

$70 \%$

$60 \%$

$50 \%$

$40 \%$

$30 \%$

$25 \%$

$20 \%$

$10 \%$

$0 \%$

$\begin{array}{rrrrrr}\text { On-Puak } & \begin{array}{c}\text { Summer } \\ \text { Somi-Pakk }\end{array} & \text { On-Poak } & \text { On-Poak } & \begin{array}{c}\text { Wintor } \\ \text { Somi-Poak }\end{array} & \text { OH-Poak } \\ (\$ 28.72) & (\$ 28.72) & (\$ 23.72) & (\$ 28.77) & (\$ 28.77) & (\$ 26.77) \\ \$ \$ 1.32 & \$ 27.20 & \$ 20.21 & \$ 37.03 & \$ 23.18 & \$ 19.12\end{array}$

\begin{tabular}{|c|c|c|c|c|c|}
\hline$\$ 7.84$ & $\$ 7.84$ & $\$ 7.84$ & SA.38 & $\$ 6.38$ & $\$ 6.30$ \\
\hline$\$ 7.05$ & $\$ 7.05$ & $\$ 7.06$ & $\$ 5.72$ & $\$ 5.72$ & $\$ 5.72$ \\
\hline$\$ 8.27$ & 83.27 & $\$ 6.27$ & $\$ 5.00$ & $\$ 5.09$ & $\$ 5.09$ \\
\hline$\$ 5.88$ & $\$ 8.88$ & $\mathbf{3 6 . 8 8}$ & $\$ 4.7$ & $\$ .77$ & $\$ 4.77$ \\
\hline$\$ 5.49$ & $\$ 5.40$ & $\$ 5.40$ & $\$ 4.45$ & $\$ 4.45$ & $\$ 4.45$ \\
\hline 84.70 & S4:70 & $\$ 4.70$ & $\$ 3.81$ & $\$ 3.81$ & $\$ 3.81$ \\
\hline$\$ 3.92$ & 83.02 & $\$ 3.92$ & $\$ 3.18$ & $\$ 3.18$ & $\$ 3.18$ \\
\hline 83.13 & $\$ 3.13$ & $\$ 3.13$ & $\$ 2.54$ & $\$ 2.54$ & $\$ 2.54$ \\
\hline$\$ 2.35$ & $\$ 2.35$ & $\$ 2.35$ & $\$ 1.91$ & $\$ 1.91$ & $\$ 1.81$ \\
\hline$\$ 1.88$ & $\$ 1.88$ & $\$ 1.80$ & $\$ 1.50$ & $\$ 1.50$ & $\$ 1.59$ \\
\hline$\$ 1.57$ & $\$ 1.57$ & $\$ 1.57$ & $\$ 1.27$ & $\$ 1.27$ & $\$ 1.27$ \\
\hline 0.78 & $\$ 0.78$ & 10.78 & $\$ 0.64$ & so.64 & $\$ 0.64$ \\
\hline$\$ 0.00$ & $\$ 0.00$ & $\$ 0.00$ & $\$ 0.00$ & $\$ 0.00$ & $\$ 0.00$ \\
\hline
\end{tabular}

\begin{tabular}{|c|c|c|c|}
\hline $\begin{array}{l}\text { On-Poak } \\
\$ 23.43\end{array}$ & $\begin{array}{r}\text { Summor } \\
\text { Somi-Peak } \\
\$ 9.31\end{array}$ & $\begin{array}{r}\text { OH-Posk } \\
\$ 2.33\end{array}$ & $\begin{array}{r}\text { On-Poak } \\
\$ 16.61\end{array}$ \\
\hline$\$ 22.65$ & $\$ 8.53$ & $\$ 1.54$ & $\$ 15.88$ \\
\hline$\$ 21.86$ & $\$ 7.75$ & $\$ 0.76$ & $\$ 15.34$ \\
\hline$\$ 21.47$ & $\$ 7.36$ & $\$ 0.37$ & $\$ 15.02$ \\
\hline$\$ 21.08$ & $\$ 8.80$ & $(\$ 0.02)$ & $\$ 14.70$ \\
\hline$\$ 20.30$ & $\$ 8.18$ & $(\$ 0.81)$ & $\$ 14.07$ \\
\hline$\$ 19.51$ & $\$ 5.30$ & $(\$ 1.50)$ & $\$ 13.43$ \\
\hline$\$ 18.73$ & $\$ 4.61$ & (\$2.37) & $\$ 12.80$ \\
\hline$\$ 17.96$ & $\$ 3.83$ & (\$3.16) & $\$ 12.16$ \\
\hline$\$ 17.55$ & $\$ 3.44$ & (\$3.56) & $\$ 11.84$ \\
\hline$\$ 17.16$ & $\$ 3.04$ & $(\$ 3.94)$ & $\$ 11.53$ \\
\hline$\$ 16.38$ & $\$ 2.28$ & (\$4.72) & $\$ 10.89$ \\
\hline$\$ 15.50$ & $\$ 1.48$ & (\$5.51) & $\$ 10.26$ \\
\hline
\end{tabular}

Winter

Somi-Peak Oft-Peak

$\$ 2.77 \quad(\$ 1.30)$

$\$ 2.13 \quad(\$ 1.93)$

$\$ 1.50 \quad(\$ 2.57)$

$\$ 1.18 \quad$ (\$2.89)

$\$ 0.86 \quad$ (\$3.21)

$\$ 0.23 \quad(\$ 3.84)$

(\$0.41) (\$4.48)

(\$1.04) (\$5.11)

$(\$ 1.68) \quad(\$ 5.75)$

$(\$ 2.00) \quad(\$ 6.07)$

(\$2.32) (\$6.38)

(\$2.95) (\$7.02)

(\$3.59) $\quad(\$ 7.66)$ 
Value of Cogenerated Energy

Thermal Load Following

Values are per engine per hour)

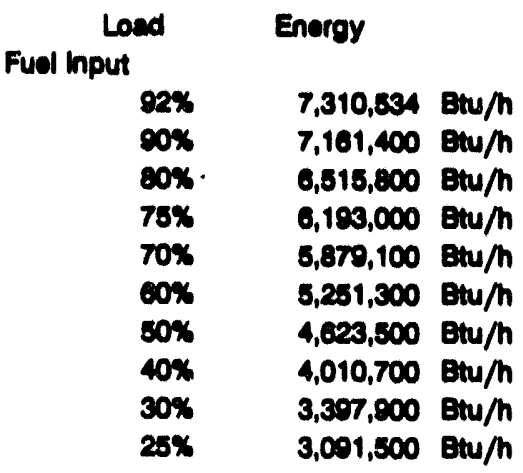

\begin{tabular}{|c|c|c|c|c|c|}
\hline n & $\begin{array}{l}\text { Summer } \\
\text { somi-Paak }\end{array}$ & On-Poak & On-Poak & $\begin{array}{l}\text { Wintor } \\
\text { Soml-Poak }\end{array}$ & Ott-Poak \\
\hline & (2025.72) & 2) & 26.77) & $(\$ 26.77)$ & (\$26.77) \\
\hline $3.2 x$ & 1203.8 & 20. & (820.23) & (826.23) & (\$20.23) \\
\hline (\$22.93) & $(122.03)$ & (202.09) & $(\$ 23.86)$ & $(\$ 23.86)$ & 23.86) \\
\hline$(\$ 21.70)$ & (201.79) & 21. & 68) & 68) & $(\$ 22.68)$ \\
\hline$(\$ 20.60)$ & & 20 & 3) & $(\$ 21.53)$ & (\$21.53) \\
\hline 18.48$)$ & (8.48) & 18. & & & 19.23) \\
\hline$(\$ 16.27)$ & $n$ & (\$16.27) & 3) & 23) & 8.021 \\
\hline (\$14.11) & $(\$ 14.11)$ & $(\$ 14.11)$ & $(\$ 14.60)$ & $(\$ 14.69)$ & $(\$ 14.69)$ \\
\hline & $(\$ 11.86)$ & 111.9 & $(\$ 12.44)$ & $(\$ 12.44)$ & (\$12.44) \\
\hline & & & 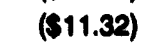 & & \\
\hline
\end{tabular}

Hoat Rocoverable and Uasable

$\begin{array}{lll}92 \% & 3,538,406 \mathrm{Btu} / \mathrm{h} \\ 90 \% & 3,464,754 \mathrm{Btu} / \mathrm{h} \\ 80 \% & 3,002,233 \mathrm{Btu} / \mathrm{h} \\ 75 \% & 2,910,973 \mathrm{Btu} / \mathrm{h} \\ 70 \% & 2,743,974 \mathrm{Btu} / \mathrm{h} \\ 60 \% & 2,400,978 \mathrm{Btw} / \mathrm{h} \\ 50 \% & 2,075,981 \mathrm{Btu} / \mathrm{h} \\ 40 \% & 1,768,571 \mathrm{Btw} / \mathrm{h} \\ 30 \% & 1,461,162 \mathrm{Btu} / \mathrm{h} \\ 25 \% & 1,307,457 \mathrm{Btu} / \mathrm{h}\end{array}$

\begin{tabular}{|c|c|c|c|c|c|}
\hline$\$ 7.87$ & $\$ 7.87$ & $\$ 7.87$ & \$.38 & \$8.38 & $\$ 6.38$ \\
\hline$\$ 7.68$ & $\$ 7.68$ & $\$ 7.68$ & $\$ 8.23$ & $\$ 6.23$ & $\$ 6.23$ \\
\hline$\$ 8.88$ & 80.88 & $\$ 6.88$ & 85.68 & $\$ 5.58$ & $\$ 5.38$ \\
\hline$\$ 9.47$ & S.47 & $\$ 8.47$ & s.25 & $\$ 5.26$ & $\$ 5.25$ \\
\hline$\$ 8.10$ & $\$ 8.10$ & $\$ 0.10$ & 54.85 & $\$ 4.95$ & $\$ 4.96$ \\
\hline$\$ 5.38$ & 15.30 & 85.38 & S4.35 & S4.35 & $\$ 4.35$ \\
\hline$\$ 4.02$ & 84.02 & $\$ 4.02$ & $\$ 3.75$ & $\$ 3.75$ & $\$ 3.75$ \\
\hline$\$ 3.93$ & $\$ 3.93$ & $\$ 3.93$ & $\$ 3.19$ & $\$ 3.19$ & $\$ 3.19$ \\
\hline$\$ 3.25$ & $\$ 3.25$ & $\$ 3.25$ & $\$ 2.64$ & $\$ 2.64$ & $\$ 2.64$ \\
\hline$\$ 2.91$ & $\$ 2.91$ & $\$ 2.91$ & $\$ 2.38$ & $\$ 2.38$ & $\$ 2.36$ \\
\hline
\end{tabular}

Electrical Output

$\begin{array}{ll}92 \% & 600 \mathrm{~kW} \\ 90 \% & 580 \mathrm{~kW} \\ 80 \% & 520 \mathrm{~kW} \\ 75 \% & 488 \mathrm{~kW} \\ 70 \% & 465 \mathrm{~kW} \\ 60 \% & 300 \mathrm{~kW} \\ 50 \% & 320 \mathrm{~kW} \\ 40 \% & 200 \mathrm{~kW} \\ 30 \% & 190 \mathrm{~kW} \\ 25 \% & 163 \mathrm{~kW}\end{array}$

\begin{tabular}{|c|c|c|c|}
\hline$\$ 41.33$ & $\$ 27.21$ & $\$ 20.22$ & $\$ 37.04$ \\
\hline$\$ 40.30$ & S28.53 & $\$ 19.72$ & $\$ 38.11$ \\
\hline$\$ 35.83$ & 123.60 & $\$ 17.53$ & 332.11 \\
\hline$\$ 33.00$ & $\$ 22.12$ & $\$ 16.4$ & s50.11 \\
\hline$\$ 31.30$ & $\$ 20.64$ & $\$ 15.34$ & $\$ 28.10$ \\
\hline$\$ 26.87$ & $\$ 17.60$ & $\$ 13.18$ & $\$ 24.08$ \\
\hline$\$ 22.38$ & $\$ 14.73$ & $\$ 10.95$ & 820.00 \\
\hline$\$ 17.92$ & $\$ 11.79$ & 89.7 & $\$ 16.00$ \\
\hline$\$ 13.46$ & 88.80 & $\$ 0.58$ & $\$ 12.08$ \\
\hline$\$ 11.22$ & $\$ 7.39$ & $\$ 5.49$ & $\$ 10.08$ \\
\hline$\$ 23.47$ & $\$ 0.35$ & $\$ 2.37$ & $\$ 16.65$ \\
\hline$\$ 22.78$ & $\$ 9.01$ & $\$ 2.20$ & $\$ 16.12$ \\
\hline$\$ 19.70$ & $\$ 7.54$ & $\$ 1.48$ & $\$ 13.83$ \\
\hline$\$ 18.20$ & $\$ 8.80$ & $\$ 1.12$ & $\$ 12.60$ \\
\hline$\$ 16.78$ & $\$ 8.00$ & so.70 & $\$ 11.52$ \\
\hline$\$ 13.75$ & $\$ 4.57$ & $\$ 0.08$ & $\$ 9.20$ \\
\hline$\$ 10.73$ & $\$ 3.08$ & $(\$ 0.70)$ & $\$ 8.87$ \\
\hline$\$ 7.74$ & $\$ 1.62$ & $(81.41)$ & $\$ 4.68$ \\
\hline$\$ 4.75$ & S0.15 & (\$2.12) & 52.25 \\
\hline$\$ 3.25$ & $(\$ 0.58)$ & $(\$ 2.48)$ & $\$ 1.10$ \\
\hline
\end{tabular}

$\begin{array}{lr}\$ 23.19 & \$ 19.12 \\ \$ 22.61 & \$ 18.64 \\ \$ 20.11 & \$ 16.58 \\ \$ 18.86 & \$ 15.56 \\ \$ 17.60 & \$ 14.51 \\ \$ 15.08 & \$ 12.43 \\ \$ 12.56 & \$ 10.35 \\ \$ 10.06 & \$ 8.29 \\ \$ 7.56 & \$ 6.23 \\ \$ 6.30 & \$ 5.19 \\ & \\ & \\ \$ 2.80 & (\$ 1.27) \\ \$ 2.62 & (\$ 1.35) \\ \$ 1.63 & (\$ 1.70) \\ \$ 1.43 & (\$ 1.88) \\ \$ 1.02 & (\$ 2.07) \\ \$ 0.19 & (\$ 2.46) \\ (\$ 0.63) & (\$ 2.83) \\ (\$ 1.44) & (\$ 3.21) \\ (\$ 2.26) & (\$ 3.58) \\ (\$ 2.66) & (\$ 3.77)\end{array}$


Value of Cogenerated Energy Electrical Load Following

Nalues are per engine per hour)

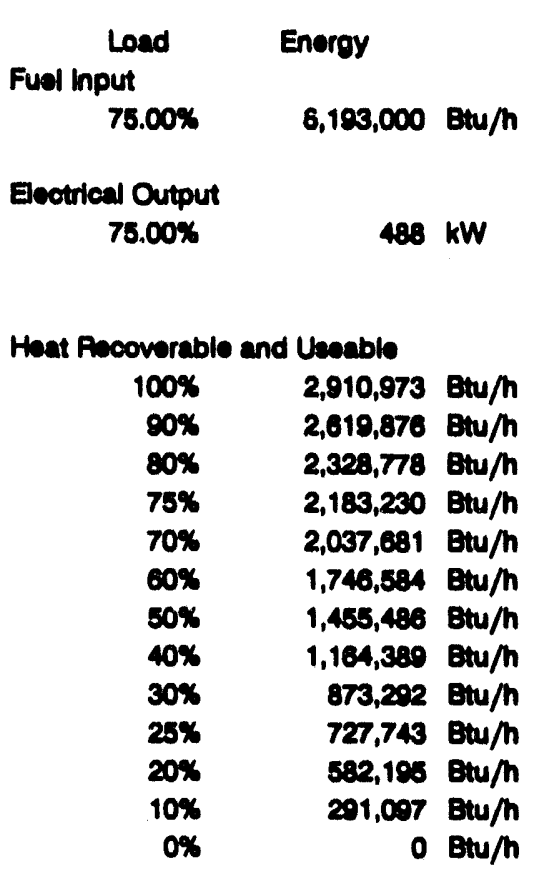

Not Marginal Value of Enorgy Useable Thermal Energy

$100 \%$

$90 \%$

$80 \%$

$75 \%$

$70 \%$

$60 \%$

$50 \%$

$40 \%$

$30 \%$

$25 \%$

$20 \%$

$10 \%$

$0 \%$

$\begin{array}{rrrrrrr}\text { On-Poak } & \begin{array}{c}\text { Summor } \\ \text { Somi-Pakk }\end{array} & \text { OHf-Poak } & \text { On-Poak } & \begin{array}{c}\text { Wintor } \\ \text { Somi-Poak }\end{array} & \text { OH-Poak } \\ (\$ 21.79) & (\$ 21.79) & (\$ 21.79) & (\$ 22.68) & (\$ 22.68) & (\$ 22.68) \\ \$ 33.60 & \$ 22.12 & \$ 16.44 & \$ 30.11 & \$ 18.86 & \$ 15.55\end{array}$

\begin{tabular}{|c|c|c|c|c|c|}
\hline$\$ 6.47$ & S6.47 & $\$ 6.47$ & $\$ 5.25$ & $\$ 5.25$ & $\$ 5.25$ \\
\hline$\$ 6.83$ & $\$ 5.83$ & $\$ 5.83$ & $\$ 4.73$ & $\$ 4.73$ & $\$ 4.73$ \\
\hline$\$ 6.18$ & $\$ 5.18$ & $\$ 5.18$ & $\$ 4.20$ & $\$ 4.20$ & $\$ 4.20$ \\
\hline$\$ 4.88$ & $\mathbf{S 4 . 8 8}$ & $\$ 4.86$ & $\$ 3.94$ & $\$ 3.94$ & $\$ 3.94$ \\
\hline$\$ 4.53$ & $\$ 4.53$ & $\$ 4.53$ & $\$ 3.68$ & $\$ 3.68$ & $\$ 3.68$ \\
\hline$\$ 3.88$ & $\$ 3.88$ & $\$ 3.88$ & $\$ 3.15$ & $\$ 3.15$ & $\$ 3.15$ \\
\hline$\$ 3.24$ & $\$ 3.24$ & $\$ 3.24$ & $\$ 2.63$ & $\$ 2.63$ & $\$ 2.63$ \\
\hline$\$ 2.50$ & $\$ 2.50$ & $\$ 2.50$ & $\$ 2.10$ & $\$ 2.10$ & $\$ 2.10$ \\
\hline$\$ 1.84$ & $\$ 1.94$ & $\$ 1.94$ & $\$ 1.58$ & $\$ 1.58$ & $\$ 1.58$ \\
\hline$\$ 1.62$ & $\$ 1.62$ & $\$ 1.02$ & $\$ 1.31$ & $\$ 1.31$ & $\$ 1.31$ \\
\hline$\$ 1.20$ & $\$ 1.20$ & $\$ 1.20$ & $\$ 1.06$ & $\$ 1.03$ & $\$ 1.05$ \\
\hline$\$ 0.65$ & so.e6 & so.es & $\$ 0.53$ & $\$ 0.53$ & $\$ 0.53$ \\
\hline$\$ 0 . \infty$ & $\$ 0.00$ & $\$ 0.00$ & $\$ 0.00$ & $\$ 0.00$ & $\$ 0.00$ \\
\hline
\end{tabular}

\begin{tabular}{|c|c|c|c|c|c|}
\hline $\begin{array}{l}\text { h-Poak } \\
\$ 18.29\end{array}$ & $\begin{array}{r}\text { Summor } \\
\text { Somi-Poak } \\
\mathbf{\$ 6 . 8 0}\end{array}$ & $\begin{array}{r}\text { Ott-Peak } \\
\$ 1.12\end{array}$ & $\begin{array}{r}\text { On-Poak } \\
\$ 12.69\end{array}$ & $\begin{array}{c}\text { Wintor } \\
\text { Semi-Poak } \\
\$ 1.43\end{array}$ & $\begin{array}{l}\text { Ott-Peak } \\
(\$ 1.88)\end{array}$ \\
\hline$\$ 17.64$ & $\$ 8.16$ & $\$ 0.48$ & $\$ 12.16$ & $\$ 0.90$ & (\$2.41) \\
\hline$\$ 16 . \infty$ & $\$ 5.51$ & (\$0.17) & $\$ 11.64$ & S0.38 & $(\$ 2.93)$ \\
\hline$\$ 16.67$ & \$5.19 & $(\$ 0.40)$ & $\$ 11.37$ & so.12 & $(\$ 3.19)$ \\
\hline$\$ 16.35$ & $\$ 4.88$ & $(\$ 0.82)$ & $\$ 11.11$ & $(\$ 0.15)$ & (\$3.46) \\
\hline$\$ 15.70$ & $\$ 4.22$ & $(\$ 1.47)$ & $\$ 10.59$ & (\$0.67) & $(\$ 3.98)$ \\
\hline$\$ 15.05$ & $\$ 3.57$ & (\$2.11) & $\$ 10.08$ & $(\$ 1.20)$ & (\$4.51) \\
\hline$\$ 14.40$ & $\$ 2.92$ & $(\$ 2.76)$ & $\$ 9.54$ & (\$1.72) & $(\$ 5.03)$ \\
\hline$\$ 13.76$ & $\$ 2.27$ & $(\$ 3.41)$ & $\$ 0.01$ & (\$2.25) & (\$5.56) \\
\hline$\$ 13.43$ & $\$ 1.85$ & (\$3.73) & $\$ 8.75$ & (\$2.51) & (\$5.82) \\
\hline$\$ 13.11$ & $\$ 1.63$ & $(\$ 4.05)$ & $\$ 8.48$ & $(\$ 2.77)$ & (\$8.08) \\
\hline$\$ 12.46$ & $\$ 0.88$ & $(\$ 4.70)$ & $\$ 7.98$ & (\$3.30) & (\$6.61) \\
\hline$\$ 11.81$ & $\$ 0.33$ & (\$5.35) & $\$ 7.43$ & $(\$ 3.82)$ & (\$7.13) \\
\hline
\end{tabular}


Value of Cogenerated Energy Electrical Load Following Nalues are per engine per hour)

\begin{tabular}{|c|c|c|}
\hline $\begin{array}{l}\text { Load } \\
\text { Fuel Input }\end{array}$ & \multicolumn{2}{|l|}{ Energy } \\
\hline $50.00 \%$ & $4,623,500$ & Btu/h \\
\hline $\begin{array}{l}\text { Electrical Outpu } \\
50.00 \%\end{array}$ & 325 & kW \\
\hline Dat Rocoverab & I Usoable & \\
\hline $\begin{array}{r}100 \% \\
80 \%\end{array}$ & $\begin{array}{l}2,075,981 \\
1,868,383\end{array}$ & $\begin{array}{l}\text { Btu/h } \\
\text { Btu/h }\end{array}$ \\
\hline $80 \%$ & $1,680,785$ & Btu/h \\
\hline $75 \%$ & $1,556,986$ & Btu/h \\
\hline $70 \%$ & $1,453,187$ & Btw/h \\
\hline $60 \%$ & $1,245,589$ & Btu/h \\
\hline $50 \%$ & $1,037,990$ & Btu/h \\
\hline $40 \%$ & 830,392 & Btu/h \\
\hline $30 \%$ & 622,794 & Btu/h \\
\hline $25 \%$ & 518,995 & Btu/h \\
\hline $20 \%$ & 415,196 & Btw/h \\
\hline $10 \%$ & 207,598 & Btu/h \\
\hline $0 \%$ & 0 & Btu/h \\
\hline
\end{tabular}

Not Marginal Value of Energy.

Useable Thermal Energy

$100 \%$

$80 \%$

$80 \%$

$75 \%$

$70 \%$

$60 \%$

$50 \%$

$40 \%$

$30 \%$

$25 \%$

$20 \%$

$10 \%$

$0 \%$

\begin{tabular}{|c|c|c|c|c|c|}
\hline On-Poak & $\begin{array}{l}\text { Summer } \\
\text { Semi-Poak }\end{array}$ & Ori-Puak & On-Poak & $\begin{array}{l}\text { Winter } \\
\text { Somi-Poak }\end{array}$ & Off-Peak \\
\hline (\$16.27) & (\$16.27) & (\$16.27) & $(\$ 16.93)$ & $(\$ 16.93)$ & (\$16. \\
\hline$\$ 22.38$ & $\$ 14.73$ & $\$ 10.97$ & $\because y^{\prime}$ & i2.56 & $\$ 10.35$ \\
\hline
\end{tabular}

$\begin{array}{llllll}\$ 4.62 & \$ 4.62 & \$ 4.62 & \$ 3.75 & \$ 3.75 & \$ 3.75 \\ \$ 4.15 & \$ 4.15 & \$ 4.15 & \$ 3.37 & \$ 3.37 & \$ 3.37 \\ \$ 3.60 & \$ 3.60 & \$ 3.60 & \$ 3.00 & \$ 3.00 & \$ 3.00 \\ \$ 3.46 & \$ 3.46 & \$ 3.46 & \$ 2.81 & \$ 2.81 & \$ 2.81 \\ \$ 3.23 & \$ 3.23 & \$ 3.23 & \$ 2.62 & \$ 2.62 & \$ 2.62 \\ \$ 2.77 & \$ 2.77 & \$ 2.77 & \$ 2.25 & \$ 2.25 & \$ 2.25 \\ \$ 2.31 & \$ 2.31 & \$ 2.31 & \$ 1.87 & \$ 1.87 & \$ 1.87 \\ \$ 1.85 & \$ 1.85 & \$ 1.86 & \$ 1.50 & \$ 1.50 & \$ 1.50 \\ \$ 1.38 & \$ 1.38 & \$ 1.38 & \$ 1.12 & \$ 1.12 & \$ 1.12 \\ \$ 1.15 & \$ 1.15 & \$ 1.15 & \$ 0.34 & \$ 0.94 & \$ 0.94 \\ \$ 0.92 & \$ 0.92 & \$ 0.92 & \$ 0.75 & \$ 0.75 & \$ 0.75 \\ \$ 0.46 & \$ 0.40 & \$ 0.40 & \$ 0.37 & \$ 0.37 & \$ 0.37 \\ \$ 0.00 & \$ 0.00 & \$ 0.00 & \$ 0.00 & \$ 0.00 & \$ 0.00\end{array}$

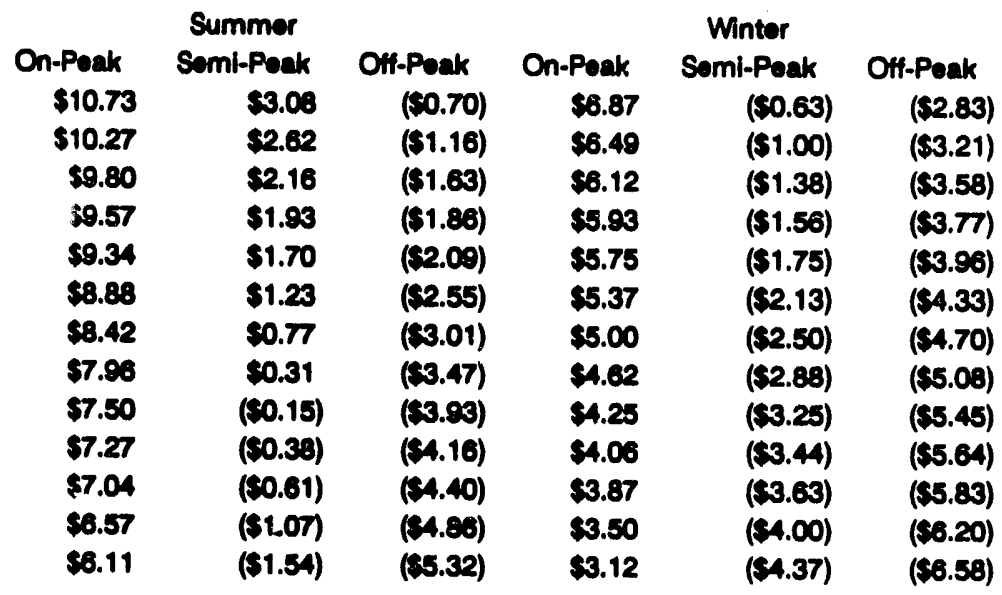




\section{Appendix F}

\section{Thermal Energy Analyses for Scenarios 1 Through 12}


TABLE F.1. Thermal Energy Analysis for Scenarios 1 - 3

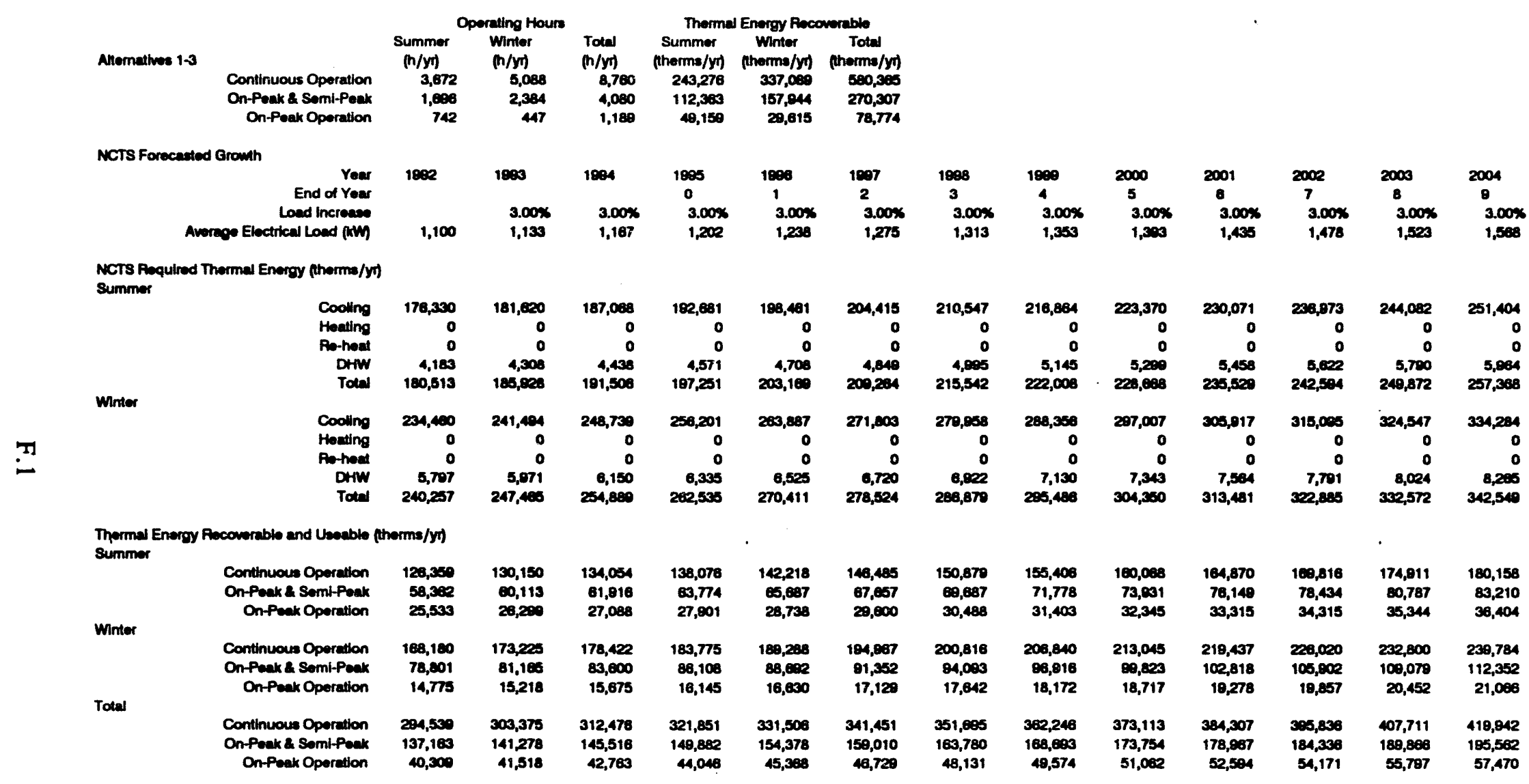


TABLE F.1. Thermal Energy Analysis for Scenarios 1 - 3 (contd)

\begin{tabular}{|c|c|c|c|c|c|c|c|c|c|c|c|c|c|c|c|}
\hline $\begin{array}{c}2005 \\
10 \\
3.00 \% \\
1,015\end{array}$ & $\begin{array}{c}2008 \\
11 \\
3.00 \% \\
1,084\end{array}$ & $\begin{array}{c}2007 \\
12 \\
3.00 \% \\
1,714\end{array}$ & $\begin{array}{c}2008 \\
13 \\
3.00 \% \\
1,765\end{array}$ & $\begin{array}{c}2000 \\
14 \\
3.00 \% \\
1,810\end{array}$ & $\begin{array}{c}2010 \\
15 \\
3.00 \% \\
1,873\end{array}$ & $\begin{array}{l}2011 \\
16 \\
3.00 \% \\
1,000\end{array}$ & $\begin{array}{l}2012 \\
17 \\
3,00 \% \\
1,007\end{array}$ & $\begin{array}{l}2013 \\
18 \\
0.66 \% \\
2,000\end{array}$ & $\begin{array}{l}2014 \\
10 \\
0.00 \% \\
2,000\end{array}$ & $\begin{array}{l}2015 \\
20 \\
0.00 \% \\
2,000\end{array}$ & $\begin{array}{l}2018 \\
21 \\
0.00 \% \\
2,000\end{array}$ & $\begin{array}{l}2017 \\
22 \\
0.00 \% \\
2,000\end{array}$ & $\begin{array}{l}2018 \\
23 \\
0.00 \% \\
2,000\end{array}$ & $\begin{array}{l}2010 \\
24 \\
0.00 \% \\
2,000\end{array}$ & $\begin{array}{l}2020 \\
25 \\
0.00 \% \\
2,000\end{array}$ \\
\hline $\begin{array}{r}258,007 \\
0 \\
0 \\
6,143 \\
285,000\end{array}$ & $\begin{array}{r}200,715 \\
0 \\
0 \\
0,327 \\
273,012\end{array}$ & $\begin{array}{r}274,710 \\
0 \\
0 \\
6,517 \\
281,233\end{array}$ & $\begin{array}{r}282,858 \\
0 \\
0 \\
0,712 \\
280,670\end{array}$ & $\begin{array}{r}201,447 \\
0 \\
0 \\
0,014 \\
200,300\end{array}$ & $\begin{array}{r}300,120 \\
0 \\
0 \\
7,121 \\
307,311\end{array}$ & $\begin{array}{r}300,198 \\
0 \\
0 \\
7,335 \\
318,531\end{array}$ & $\begin{array}{r}318,472 \\
0 \\
0 \\
7,505 \\
326,027\end{array}$ & $\begin{array}{r}320,542 \\
0 \\
0 \\
7,004 \\
320,140\end{array}$ & $\begin{array}{r}320,542 \\
0 \\
0 \\
7,004 \\
328,140\end{array}$ & $\begin{array}{r}320,542 \\
0 \\
0 \\
7,004 \\
328,140\end{array}$ & $\begin{array}{r}320,542 \\
0 \\
0 \\
7,004 \\
320,146\end{array}$ & $\begin{array}{r}320,512 \\
0 \\
0 \\
7,604 \\
328,140\end{array}$ & $\begin{array}{r}320,512 \\
0 \\
0 \\
7,604 \\
328,140\end{array}$ & $\begin{array}{r}320,502 \\
0 \\
0 \\
7,004 \\
320,140\end{array}$ & $\begin{array}{r}320,542 \\
0 \\
0 \\
7,604 \\
328,146\end{array}$ \\
\hline $\begin{array}{r}344,312 \\
0 \\
0 \\
8,513 \\
362,820\end{array}$ & $\begin{array}{r}364,042 \\
0 \\
0 \\
8,708 \\
303,410\end{array}$ & $\begin{array}{r}36,281 \\
0 \\
0 \\
8,032 \\
374,313\end{array}$ & $\begin{array}{r}378,230 \\
0 \\
0 \\
0,302 \\
385,542\end{array}$ & $\begin{array}{r}387,627 \\
0 \\
0 \\
90,582 \\
307,108\end{array}$ & $\begin{array}{r}300,152 \\
0 \\
0 \\
9,800 \\
400, \infty 11\end{array}$ & $\begin{array}{r}41,127 \\
0 \\
0 \\
10,120 \\
421,202\end{array}$ & $\begin{array}{r}423,401 \\
0 \\
0 \\
10,470 \\
433,031\end{array}$ & $\begin{array}{r}420,213 \\
0 \\
0 \\
10,536 \\
436,751\end{array}$ & $\begin{array}{r}426,213 \\
0 \\
0 \\
10,538 \\
436,751\end{array}$ & $\begin{array}{r}428,213 \\
0 \\
0 \\
10,536 \\
436,751\end{array}$ & $\begin{array}{r}488,213 \\
0 \\
0 \\
10,538 \\
436,751\end{array}$ & $\begin{array}{r}428,213 \\
0 \\
0 \\
10,538 \\
438,751\end{array}$ & $\begin{array}{r}420,213 \\
0 \\
0 \\
10,536 \\
430,751\end{array}$ & $\begin{array}{r}420,213 \\
0 \\
0 \\
10,538 \\
406,731\end{array}$ & $\begin{array}{r}428,213 \\
0 \\
0 \\
10,538 \\
436,751\end{array}$ \\
\hline $\begin{array}{r}186,503 \\
85,700 \\
37,407\end{array}$ & $\begin{array}{r}191,120 \\
88,270 \\
36,021\end{array}$ & $\begin{array}{c}\mathbf{1 9 8 , 8 0 3} \\
\mathbf{9 0 , 0 2 0 6} \\
\mathbf{3 0 , 7 8 0}\end{array}$ & $\begin{array}{c}202,700 \\
93,064 \\
40,074\end{array}$ & $\begin{array}{r}206,2060 \\
00,403 \\
42,203\end{array}$ & $\begin{array}{r}215,118 \\
10,367 \\
43,460\end{array}$ & $\begin{array}{r}221,571 \\
102,336 \\
44,773\end{array}$ & $\begin{array}{r}228,210 \\
105,408 \\
46,116\end{array}$ & $\begin{array}{c}200,700 \\
100,003 \\
40,416\end{array}$ & $\begin{array}{r}220,702 \\
100,003 \\
40,416\end{array}$ & $\begin{array}{r}220,702 \\
108,000 \\
46,410\end{array}$ & $\begin{array}{r}220,702 \\
108,003 \\
46,416\end{array}$ & $\begin{array}{r}220,702 \\
106,003 \\
46,416\end{array}$ & $\begin{array}{r}200,700 \\
108,000 \\
46,410\end{array}$ & $\begin{array}{r}200,700 \\
100,0003 \\
40,416\end{array}$ & $\begin{array}{r}209,702 \\
105,000 \\
40,416\end{array}$ \\
\hline $\begin{array}{r}246,078 \\
115,722 \\
21,608\end{array}$ & $\begin{array}{r}254,367 \\
110,104 \\
22,349\end{array}$ & $\begin{array}{r}282,019 \\
122,770 \\
23,010\end{array}$ & $\begin{array}{r}200,870 \\
126,453 \\
23,710\end{array}$ & $\begin{array}{r}27,070 \\
130,240 \\
24,421\end{array}$ & $\begin{array}{c}280,315 \\
134,154 \\
25,154\end{array}$ & $\begin{array}{r}28,004 \\
138,170 \\
25,808\end{array}$ & $\begin{array}{r}303,752 \\
142,324 \\
28,668\end{array}$ & $\begin{array}{r}305,728 \\
143,240 \\
20,850\end{array}$ & $\begin{array}{r}305,728 \\
143,240 \\
28,850\end{array}$ & $\begin{array}{r}305,728 \\
143,240 \\
28,060\end{array}$ & $\begin{array}{r}305,720 \\
143,260 \\
20,060\end{array}$ & $\begin{array}{r}305,720 \\
143,240 \\
28,850\end{array}$ & $\begin{array}{r}305,728 \\
143,240 \\
28,860\end{array}$ & $\begin{array}{r}306,720 \\
143,240 \\
20,060\end{array}$ & $\begin{array}{r}306,728 \\
143,240 \\
28,650\end{array}$ \\
\hline $\begin{array}{r}432,540 \\
201,420 \\
50,105\end{array}$ & $\begin{array}{r}445,517 \\
207,472 \\
60,070\end{array}$ & $\begin{array}{r}458,802 \\
213,000 \\
62,700\end{array}$ & $\begin{array}{r}472,640 \\
220,107 \\
64,683\end{array}$ & $\begin{array}{r}486,028 \\
220,710 \\
60,024\end{array}$ & $\begin{array}{r}501,433 \\
233,511 \\
68,623\end{array}$ & $\begin{array}{r}516,478 \\
240,517 \\
70,681\end{array}$ & $\begin{array}{r}531,970 \\
247,732 \\
72,802\end{array}$ & $\begin{array}{c}535,428 \\
240,362 \\
73,275\end{array}$ & $\begin{array}{r}535,428 \\
240,342 \\
73,275\end{array}$ & $\begin{array}{c}535,428 \\
240,342 \\
73,275\end{array}$ & $\begin{array}{r}535,428 \\
249,342 \\
73,275\end{array}$ & $\begin{array}{r}535,428 \\
249,312 \\
73,275\end{array}$ & $\begin{array}{r}535,428 \\
240,312 \\
73,275\end{array}$ & $\begin{array}{r}536,428 \\
240,342 \\
73,275\end{array}$ & $\begin{array}{c}536,428 \\
249,362 \\
73,275\end{array}$ \\
\hline
\end{tabular}


TABLE F.2. Thermal Energy Analysis for Scenarios 4 - 6

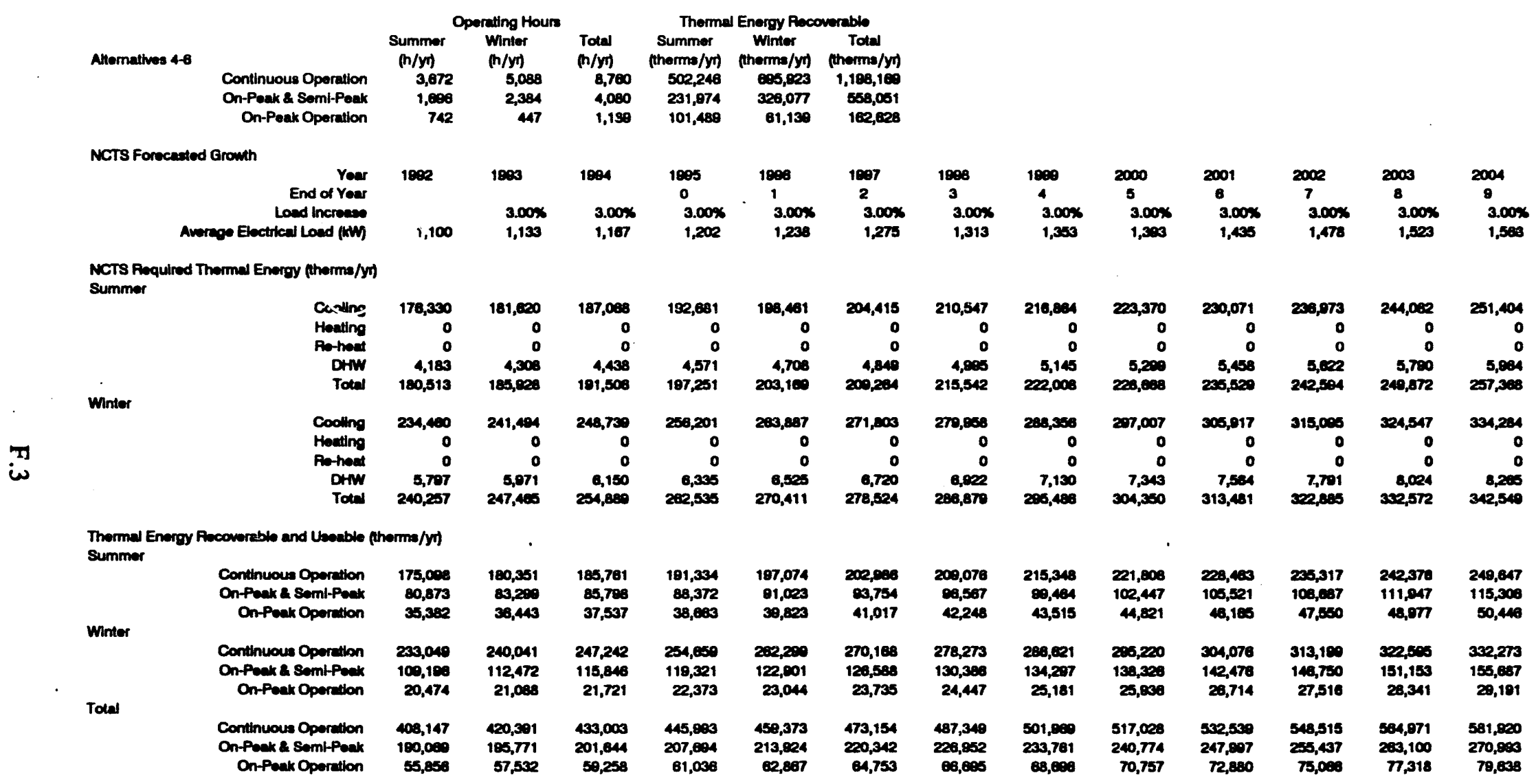


TABLE F.2. Thermal Energy Analysis for Scenarios 4 - 6 (contd)

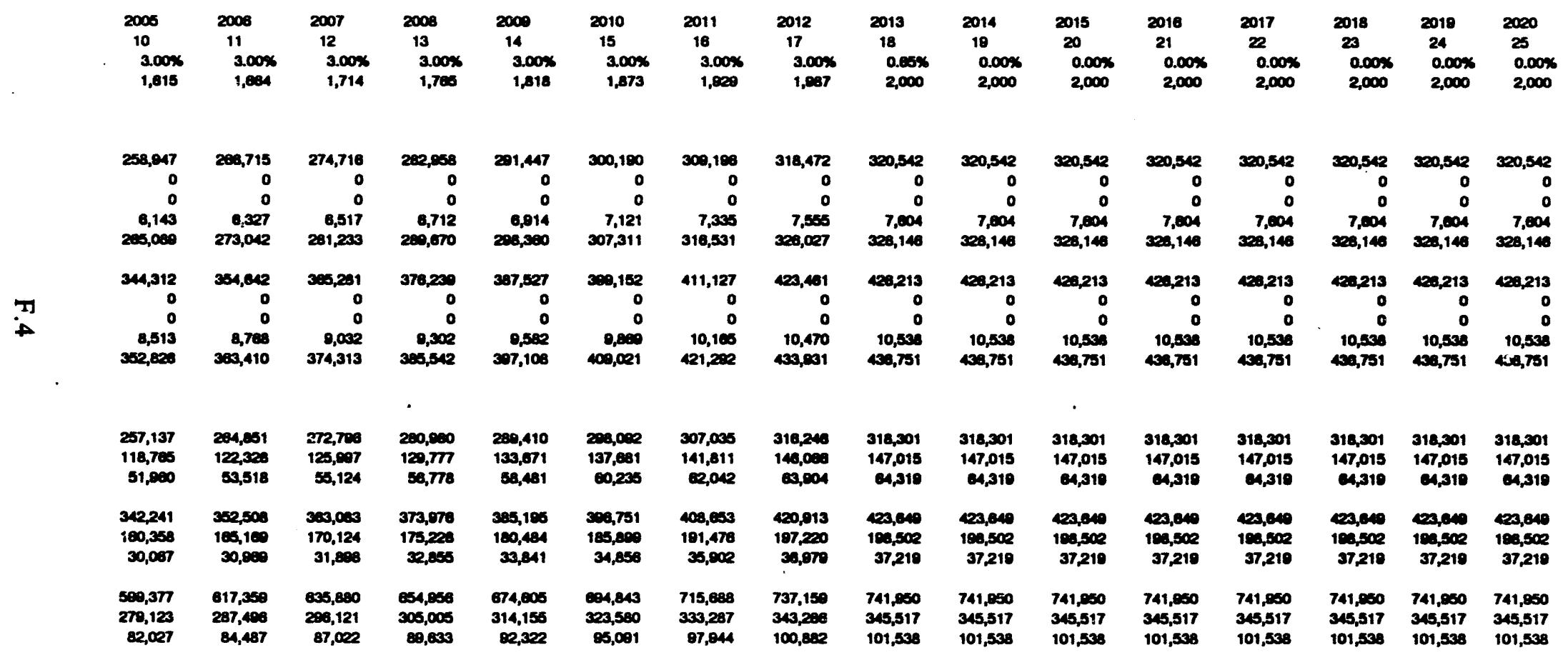


TABLE F.3. Thermal Energy Analysis for Scenarios 7 - 9

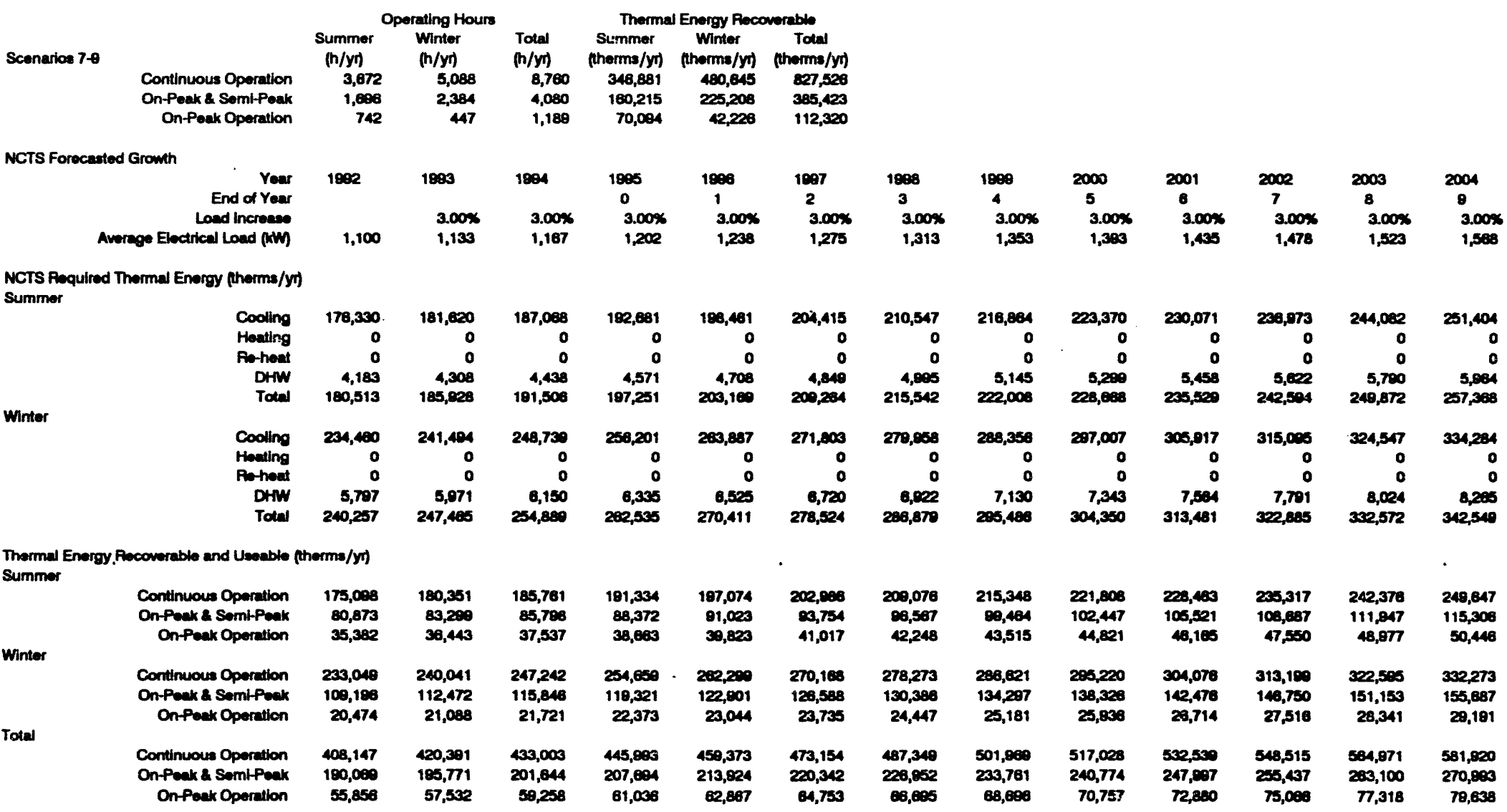


TABLE F.3. Thermal Energy Analysis for Scenarios 7 - 9 (contd)

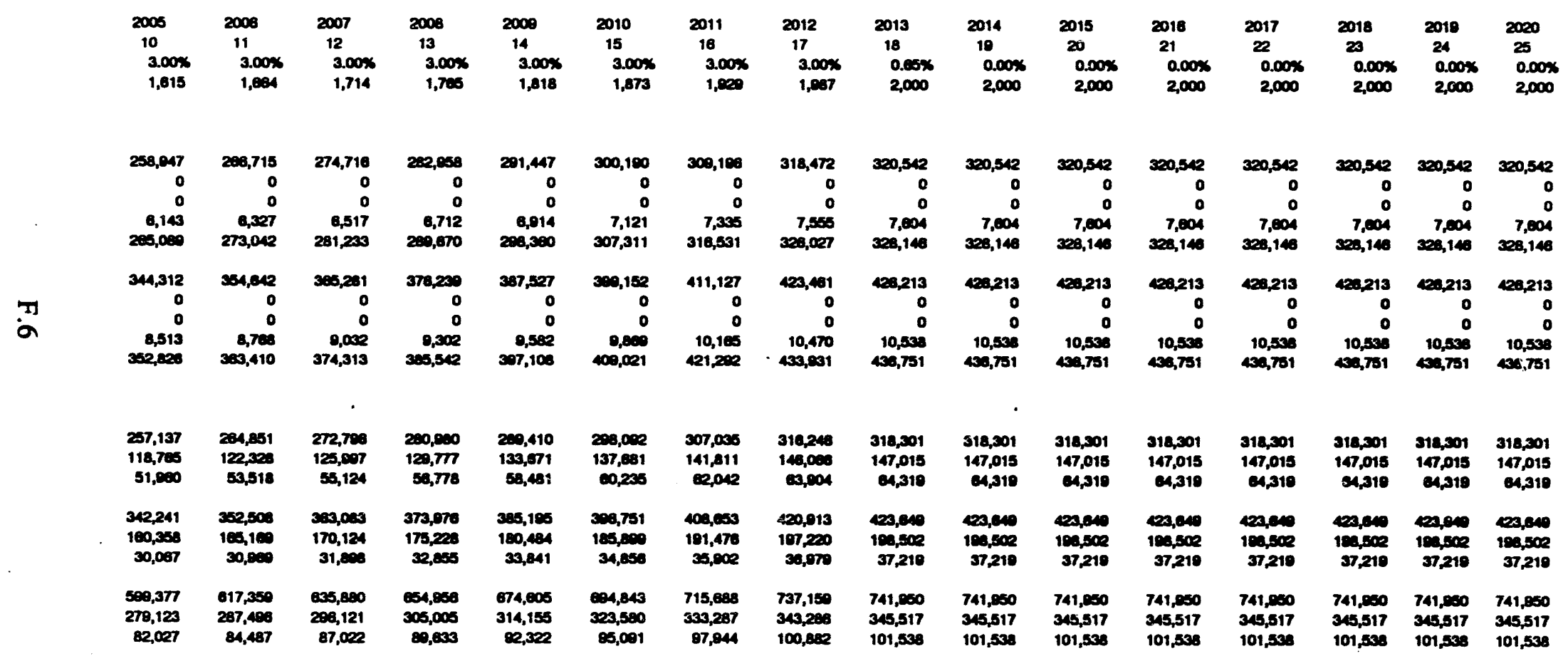


TABLE F.4. Thermal Energy Analysis for Scenarios $10-12$

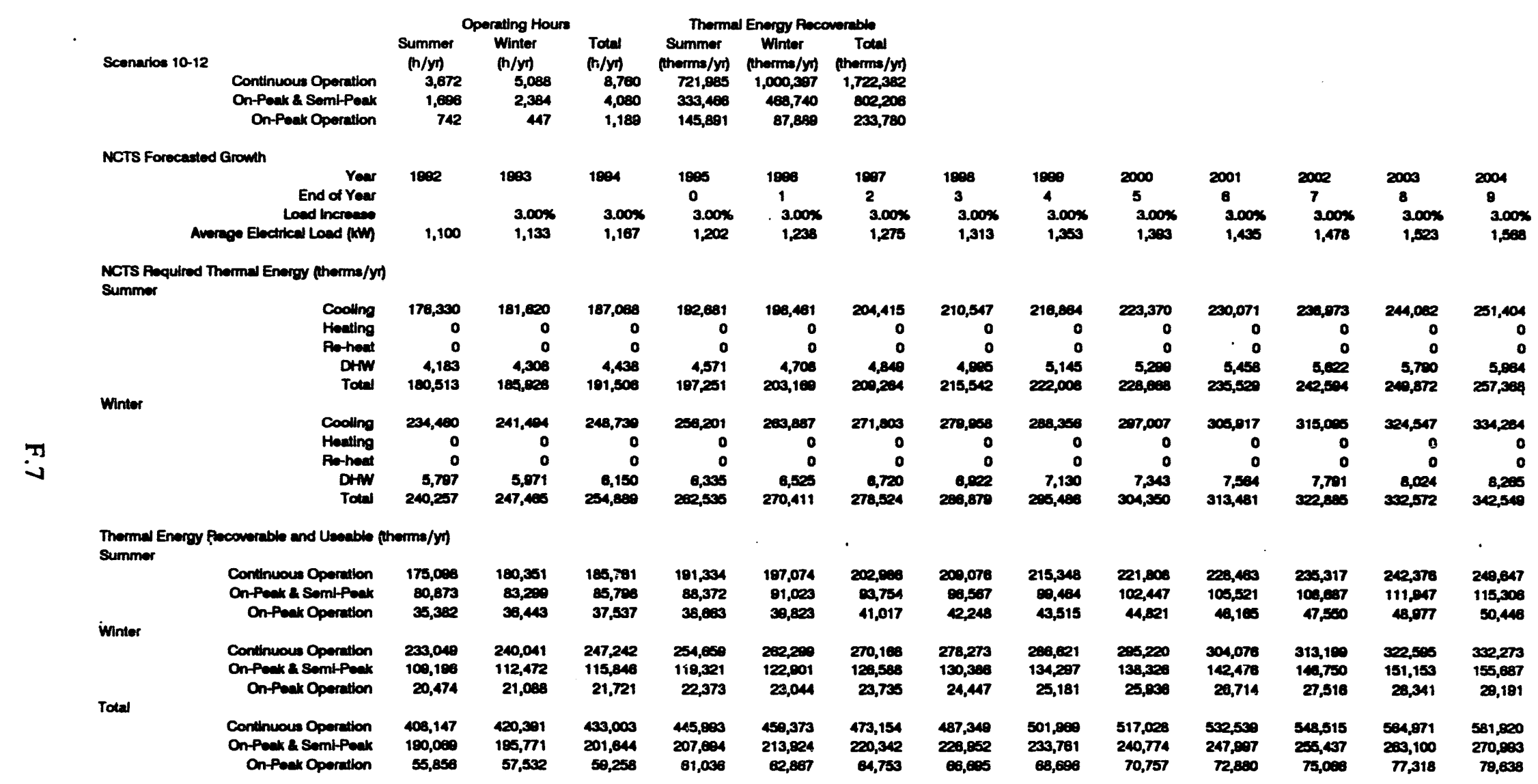


TABLE F.4. Thermal Energy Analysis for Scenarios 10 - 12 (contd)

\begin{tabular}{|c|c|c|c|c|c|c|c|c|c|c|c|c|c|c|c|}
\hline $\begin{array}{c}2005 \\
10 \\
3.00 \% \\
1,615\end{array}$ & $\begin{array}{c}2008 \\
11 \\
3.00 \% \\
1,004\end{array}$ & $\begin{array}{c}2007 \\
12 \\
3.00 \% \\
1,714\end{array}$ & $\begin{array}{l}2008 \\
13 \\
3.00 \% \\
1,786\end{array}$ & $\begin{array}{l}2000 \\
14 \\
3.00 x \\
1,018\end{array}$ & $\begin{array}{l}2010 \\
15 \\
3.00 \% \\
1,873\end{array}$ & $\begin{array}{c}2011 \\
18 \\
3.00 \% \\
1,000\end{array}$ & $\begin{array}{l}2012 \\
17 \\
3.00 \% \\
1,007\end{array}$ & $\begin{array}{l}2013 \\
18 \\
0.65 \% \\
2,000\end{array}$ & $\begin{array}{c}2014 \\
10 \\
0.00 x \\
2,000\end{array}$ & $\begin{array}{l}2015 \\
20 \\
0.00 \% \\
2,000\end{array}$ & $\begin{array}{l}2010 \\
21 \\
0.00 \% \\
2,000\end{array}$ & $\begin{array}{c}2017 \\
22 \\
0.00 \% \\
2,000\end{array}$ & $\begin{array}{l}2018 \\
23 \\
0,00 \% \\
2,000\end{array}$ & $\begin{array}{l}2010 \\
24 \\
0.00 \% \\
2,000\end{array}$ & $\begin{array}{l}2020 \\
25 \\
0.00 \% \\
2,000\end{array}$ \\
\hline $\begin{array}{r}258,047 \\
0 \\
0 \\
0,143 \\
205,000\end{array}$ & $\begin{array}{r}263,715 \\
0 \\
0 \\
8,327 \\
273,042\end{array}$ & $\begin{array}{r}274,716 \\
0 \\
0 \\
6,517 \\
281,233\end{array}$ & $\begin{array}{r}282,858 \\
0 \\
0 \\
6,712 \\
200,670\end{array}$ & $\begin{array}{r}201,447 \\
0 \\
0 \\
6,014 \\
208,300\end{array}$ & $\begin{array}{r}300,100 \\
0 \\
0 \\
7,121 \\
307,311\end{array}$ & $\begin{array}{r}300,188 \\
0 \\
0 \\
7,3385 \\
310,531\end{array}$ & $\begin{array}{r}318,472 \\
0 \\
0 \\
77,505 \\
320,027\end{array}$ & $\begin{array}{r}320,512 \\
0 \\
0 \\
7,004 \\
320,140\end{array}$ & $\begin{array}{r}320,542 \\
0 \\
0 \\
7,004 \\
320,140\end{array}$ & $\begin{array}{r}320,542 \\
0 \\
0 \\
7,004 \\
320,140\end{array}$ & $\begin{array}{r}320,512 \\
0 \\
0 \\
7,004 \\
320,140\end{array}$ & $\begin{array}{r}320,540 \\
0 \\
0 \\
7,004 \\
308,140\end{array}$ & $\begin{array}{r}320,512 \\
0 \\
0 \\
7,008 \\
200,140\end{array}$ & $\begin{array}{r}320,512 \\
0 \\
0 \\
7,004 \\
320,140\end{array}$ & $\begin{array}{r}320,512 \\
0 \\
0 \\
7,604 \\
320,148\end{array}$ \\
\hline $\begin{array}{r}340,312 \\
0 \\
0 \\
8,513 \\
362,020\end{array}$ & $\begin{array}{r}36,042 \\
0 \\
0 \\
0,783 \\
303,410\end{array}$ & $\begin{array}{r}306,281 \\
0 \\
0 \\
0,032 \\
374,313\end{array}$ & $\begin{array}{r}378,2200 \\
0 \\
0 \\
0,302 \\
305,512\end{array}$ & $\begin{array}{r}387,527 \\
0 \\
0 \\
0,502 \\
307,108\end{array}$ & $\begin{array}{r}300,182 \\
0 \\
0 \\
00,000 \\
400,021\end{array}$ & $\begin{array}{r}411,127 \\
0 \\
0 \\
10,106 \\
121,202\end{array}$ & $\begin{array}{r}423,401 \\
0 \\
0 \\
10,470 \\
430,001\end{array}$ & $\begin{array}{r}420,213 \\
0 \\
0 \\
10,530 \\
430,751\end{array}$ & $\begin{array}{r}428,213 \\
0 \\
0 \\
10,536 \\
430,751\end{array}$ & $\begin{array}{r}420,213 \\
0 \\
0 \\
10,536 \\
438,751\end{array}$ & $\begin{array}{r}42,213 \\
0 \\
0 \\
10,320 \\
438,751\end{array}$ & $\begin{array}{r}420,213 \\
0 \\
0 \\
10,536 \\
420,751\end{array}$ & $\begin{array}{r}420,213 \\
0 \\
0 \\
10,508 \\
438,751\end{array}$ & $\begin{array}{r}120,213 \\
0 \\
0 \\
10,530 \\
40,751\end{array}$ & $\begin{array}{r}428,213 \\
0 \\
0 \\
10,538 \\
438,751\end{array}$ \\
\hline $\begin{array}{r}257,137 \\
118,785 \\
51,080\end{array}$ & $\begin{array}{c}284,861 \\
122,328 \\
53,510\end{array}$ & $\begin{array}{r}272,790 \\
125,807 \\
55,124\end{array}$ & $\begin{array}{c}280,800 \\
120, m \\
58,776\end{array}$ & $\begin{array}{c}268,410 \\
133,671 \\
58,481\end{array}$ & $\begin{array}{c}208,002 \\
137,061 \\
60,236\end{array}$ & $\begin{array}{r}307,035 \\
141,811 \\
62,042\end{array}$ & $\begin{array}{c}318,240 \\
146,000 \\
63,004\end{array}$ & $\begin{array}{r}318,301 \\
147,015 \\
64,310\end{array}$ & $\begin{array}{r}318,301 \\
147,015 \\
84,310\end{array}$ & $\begin{array}{r}318,301 \\
147,015 \\
64,310\end{array}$ & $\begin{array}{r}316,301 \\
147,015 \\
04,310\end{array}$ & $\begin{array}{r}318,301 \\
147,015 \\
04,310\end{array}$ & $\begin{array}{r}318,301 \\
147,015 \\
04,310\end{array}$ & $\begin{array}{c}316,301 \\
147,015 \\
64,310\end{array}$ & $\begin{array}{r}318,301 \\
147,015 \\
84,310\end{array}$ \\
\hline $\begin{array}{r}312,241 \\
160,366 \\
30,067\end{array}$ & $\begin{array}{c}362,506 \\
185,160 \\
30,860\end{array}$ & $\begin{array}{r}363,063 \\
170,124 \\
31,808\end{array}$ & $\begin{array}{r}373,070 \\
175,220 \\
32,056\end{array}$ & $\begin{array}{r}385,185 \\
180,484 \\
33,841\end{array}$ & $\begin{array}{r}300,751 \\
186,000 \\
34,850\end{array}$ & $\begin{array}{c}408,063 \\
101,476 \\
35,000\end{array}$ & $\begin{array}{r}120,013 \\
197,220 \\
36,070\end{array}$ & $\begin{array}{r}423,010 \\
100,502 \\
37,210\end{array}$ & $\begin{array}{r}103,610 \\
100,502 \\
37,210\end{array}$ & $\begin{array}{r}423,010 \\
106,502 \\
37,210\end{array}$ & $\begin{array}{r}123,010 \\
190,502 \\
37,210\end{array}$ & $\begin{array}{r}423,0600 \\
106,502 \\
37,210\end{array}$ & $\begin{array}{r}123,810 \\
100,602 \\
37,210\end{array}$ & $\begin{array}{r}129,0100 \\
100,502 \\
37,210\end{array}$ & $\begin{array}{c}128,060 \\
100,502 \\
37,210\end{array}$ \\
\hline $\begin{array}{l}509,37 \\
270,123 \\
82,027\end{array}$ & $\begin{array}{r}817,360 \\
287,460 \\
84,487\end{array}$ & $\begin{array}{r}635,880 \\
298,121 \\
87,022\end{array}$ & $\begin{array}{r}65 A, 060 \\
305,006 \\
88,033\end{array}$ & $\begin{array}{c}674,005 \\
314,155 \\
02,302\end{array}$ & $\begin{array}{c}194,843 \\
323,500 \\
85,001\end{array}$ & $\begin{array}{r}715,688 \\
333,287 \\
97,944\end{array}$ & $\begin{array}{l}737,150 \\
343,286 \\
100,862\end{array}$ & $\begin{array}{l}741,860 \\
345,517 \\
101,536\end{array}$ & $\begin{array}{l}741,050 \\
345,517 \\
101,536\end{array}$ & $\begin{array}{l}741,050 \\
345,517 \\
101,538\end{array}$ & $\begin{array}{l}741,050 \\
345,517 \\
101,536\end{array}$ & $\begin{array}{l}741,060 \\
345,517 \\
101,536\end{array}$ & $\begin{array}{l}741,950 \\
345,517 \\
101,530\end{array}$ & $\begin{array}{l}741,080 \\
345,517 \\
101,533\end{array}$ & $\begin{array}{l}741,000 \\
345,517 \\
101,536\end{array}$ \\
\hline
\end{tabular}


Appendix G

Energy Analyses for Scenarios 1 Through 12 
TABLE G.1. Energy Analysis for Scenario 1

Reciprocating Engine Data:

Number of Engines

Conorator Capadty

Contracted Demand

Hoat Rate (HHV)

Thermal Rocovery

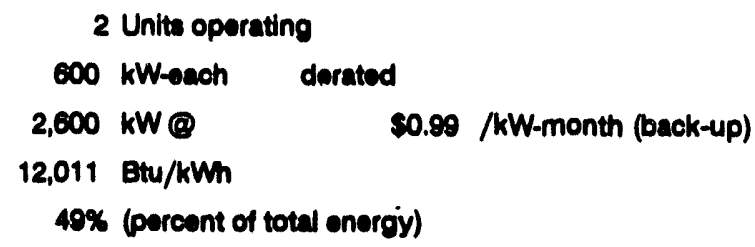

\section{Oporating Sohodule: \\ On-Poak \\ Somi-Poak \\ Otf-Peak}

Available Operating Hours

Scheduled Downtime

Not Operating Hours

Not Utilization of Hours

Load Utilization Factor

Powerhouse Load

$\begin{array}{cc}\text { Summor } & \text { Minter } \\ Y & Y \\ Y & Y \\ Y & Y\end{array}$

$8,760 \mathrm{~h} / \mathrm{yr}$

\begin{tabular}{l}
$0 \mathrm{~h} / \mathrm{yr} \quad$ Assumes 2 of 4 engines always operating. \\
\hline $8,760 \mathrm{~h} / \mathrm{yr}$ \\
$100 \%$ \\
$94 \%$ (average engine load factor when in operation) \\
$1.25 \%$ (percent of load used in powerhouse)
\end{tabular}

\begin{tabular}{|c|c|c|c|c|c|c|}
\hline \multicolumn{2}{|c|}{ Electrio Rate Schodulo: } & \multirow{2}{*}{$\begin{array}{r}\text { Hours/Yr } \\
742\end{array}$} & \multirow{2}{*}{$\begin{array}{l}\text { Enorgy } \\
\$ 0.06886\end{array}$} & \multirow[t]{2}{*}{$(\$ / k W n)$} & \multirow{2}{*}{$\begin{array}{l}\text { Demand } \\
\$ 13.39\end{array}$} & \multirow[t]{2}{*}{$(\mathbf{s} / \mathrm{kW})$} \\
\hline Summer & On-Peak & & & & & \\
\hline & Somi-Poak & 954 & $\$ 0.04533$ & & $\$ 1.24$ & \\
\hline & Otf-Peak & 1,976 & $\$ 0.03368$ & & & \\
\hline & sub-total & 3,672 & & & & \\
\hline \multirow[t]{5}{*}{ Winter } & On-Peak & 447 & $\$ 0.06171$ & & $\$ 2.17$ & \\
\hline & Somi-Poak & 1,837 & $\$ 0.03864$ & & $\$ 1.24$ & \\
\hline & Ott-Poak & 2,704 & $\$ 0.03186$ & & & \\
\hline & sub-total & 5,088 & & & & \\
\hline & Total & 8,780 & & & & \\
\hline \multicolumn{2}{|c|}{ Natural Gas Rate Schodulo: } & Hours $/ \mathrm{Yr}$ & Enorgy & (\$/therm) & & \\
\hline \multirow[t]{3}{*}{ Winter } & Cogen Rate & 2,904 & $\$ 0.30895$ & & 0.107 & therm/kWh \\
\hline & Non-cogen Rate & 2,904 & $\$ 0.36622$ & & 1,032 & Btu/cuft HHV \\
\hline & & & & & 928.8 & Btu/cutt LHV \\
\hline \multirow[t]{2}{*}{ Summer } & Cogen Rate & 5,856 & $\$ 0.30375$ & & & \\
\hline & Non-cogen Rato & 5,858 & $\$ 0.35185$ & & & \\
\hline \multicolumn{2}{|c|}{ Stoam Rate Schedulo: } & Hours/Vr & Enorgy & (\$/thorm) & & \\
\hline Summer & Marginal Rate & 3,672 & $\$ 0.222$ & & & \\
\hline \multirow[t]{2}{*}{ Wintor. } & Marginal Rato & 5,088 & $\$ 0.180$ & & & \\
\hline & & 8,760 & & & & \\
\hline
\end{tabular}

G. 1 
TABLE G.1. Energy Analysis for Scenario 1 (contd)

\begin{tabular}{|c|c|c|c|c|c|c|c|}
\hline \multicolumn{2}{|c|}{ Natural Gas Consumed: } & \multirow{2}{*}{$\begin{array}{l}\text { Enorgy } \\
357,196\end{array}$} & \multirow[t]{2}{*}{ (therm/yr) } & \multirow{3}{*}{$\begin{array}{l}\text { Value } \\
\$ 110,388 \\
\$ 17,880 \\
\end{array}$} & \multirow[t]{3}{*}{$(s / y r)$} & & \\
\hline Winter & Cogen Rate & & & & & & \\
\hline & Non-cogen Rate & 48,840 & & & & & \\
\hline & sub-total & 408,088 & & $\$ 128,242$ & & & \\
\hline \multirow[t]{3}{*}{ Summer } & Cogen Rato & 720,290 & & $\$ 218,790$ & & & \\
\hline & Non-cogen Rate & 98,488 & & $\$ 34,683$ & & & \\
\hline & sub-total & 818,783 & & $\$ 253,448$ & & & \\
\hline \multicolumn{2}{|l|}{ Total } & $1,224,810$ & & $\$ 381,686$ & & & \\
\hline \multicolumn{2}{|c|}{ Electricity Genorated: } & Enorgy & $(\mathrm{kWh} / \mathrm{yr})$ & Domand & $(k W)$ & & \\
\hline \multirow[t]{3}{*}{ Summor } & On-Poak & 836,976 & & $i, 200$ & & & \\
\hline & Somi-Poak & $1,076,112$ & & 1,200 & & & \\
\hline & Orf-Poak & $2,228,828$ & & & & & \\
\hline \multirow[t]{3}{*}{ Winter } & On-Poak & 504,216 & & 1,200 & & & \\
\hline & Somt-Poak & $2,184,236$ & & 1,200 & & & \\
\hline & Off-Poak & $3,050,112$ & & & & & \\
\hline \multicolumn{2}{|c|}{ Not Electricty Genorated: } & Enorgy & $(\mathrm{kWh} / \mathrm{yr})$ & Domand & (kM) & Value & $(S / y r)$ \\
\hline \multirow[t]{4}{*}{ Summir } & On-Poak & 828,514 & & 1,185 & & $\$ 136,249$ & \\
\hline & Somi-Poak & $1,062,661$ & & 1,185 & & $\$ 55,517$ & \\
\hline & OH-Peak & $2,201,066$ & & & & $\$ 74,154$ & \\
\hline & sub-total & $4,090,241$ & & & & $\$ 265,921$ & \\
\hline \multirow[t]{4}{*}{ Winter } & On-Poak & 497,913 & & 1,185 & & $\$ 48,726$ & \\
\hline & Somi-Poak & $2,157,624$ & & 1,185 & & $\$ 93,656$ & \\
\hline & Off-Poak & $3,011,986$ & & & & $\$ 95,962$ & \\
\hline & sub-total & $5,667,523$ & & & & $\$ 238,345$ & \\
\hline \multicolumn{2}{|l|}{ Total } & $9,757,764$ & & - & & $\$ 504,265$ & \\
\hline \multirow{2}{*}{\multicolumn{2}{|c|}{ Thermal Energy Recoverable: }} & Summer & & Wintor & & Total & \\
\hline & & 243,276 & therms/yr & 337,089 & therms/yr & 580,365 & therms/yr \\
\hline \multicolumn{2}{|c|}{ Required Thermal Energy: } & Summor & (thorms/yr) & Winter & (therms/yr) & Total & (therms/yr) \\
\hline & Cooling & 176,330 & & 234,460 & & 410,790 & \\
\hline & Hoating & 0 & & $\mathbf{0}$ & & 0 & \\
\hline & Re-Hat & 0 & . & 0 & & 0 & \\
\hline & DHW & 4,183 & & 5,797 & & 9,980 & \\
\hline & sub-total & 180,513 & & 240,257 & & 420,770 & \\
\hline
\end{tabular}


TABLE G.1. Energy Analysis for Scenario 1 (contd)

Thermal Eneroy Rcooverable \& Uesable:

\begin{tabular}{|c|c|c|c|c|c|}
\hline & Enorgy & (therms/yr) & Stwam & (Mlbs/yr) & Value \\
\hline Summer & 126,350 & & 14,320 & & $\$ 28,100$ \\
\hline Wintor & 168,180 & & 10,008 & & $\$ 30,345$ \\
\hline Total & 204,580 & & 33,304 & & $\$ 58,444$ \\
\hline
\end{tabular}

Summary of Calculations: '

$\begin{array}{lr}\text { Natural Gas Fuel Cost } & (\$ 381,686) / \mathrm{yr} \\ \text { Electrical Savings } & (504,285 / \mathrm{yr} \\ \text { SDG\&E Back-up Cost } & (\$ 30,888) / \mathrm{yr} \\ \text { Thermal Savings } & \$ 58,444 / \mathrm{yr} \\ \text { Not Energy Savings } & 150,137 / \mathrm{yr}\end{array}$

Average SDG\&E/FERC Efficionoy $\quad 43.57 \% \quad 42.5 \%$ or greater required for cogen gas rate

Does quality for cogen gas rate.

G.3 
TABLE G.2. Energy Analysis for Scenario 2

Reciprocating Engine Data:

Number of Engines

Gonorator Capacity

Contracted Domand

Họat Rate (HHM)

Thermal Recovery

Oporating Schodule:

On-Peak

Somi-Poak

Off-Poak

2 Units operating
$600 \mathrm{~kW}$-ach derated
$2,600 \mathrm{~kW} @ \quad \$ 0.99 / \mathrm{kW}$-month (back-up)
12,011 Btu/kWh
$40 \%$ (percent of total energy)

$\begin{array}{cc}\text { Summer } & \text { Wintor } \\ Y & Y \\ Y & Y \\ N & N\end{array}$

Avallable Oporating Houry

Scheduled Downtime

Not Operating Hours

Not Utillization of Hours

Load Uallization Factor

Powerhoues Load

Eectric Rate Schedule:

Summor

On-Peak

Seml-Poak

Off-Poak

sub-total

Wnter

On-Peak

Soml-Poak

Ott-Peak

sub-total

Total

Natural Gas Rate Schedule:

Winter Cogen Rato

Non-cogen Rate

Summer

Cogen Rate

Non-cogen Rate

Steam Rate Schodule:

Summer Marginal Rate

Winter Marginal Rate

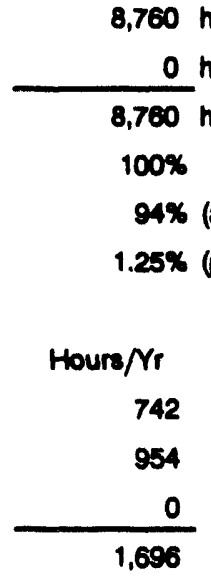

$\begin{array}{r}447 \\ 1,937 \\ 0 \\ \hline 2,384 \\ \hline 4,000\end{array}$

Hours/Yr

1,344

1,344

2,736

2,736

Hours/Yr

1,606

2,384

4,080
$\$ 0.06171$

$\$ 2.17$

$\$ 0.03864$

$\$ 1.24$

$\$ 0.03186$

Energy $(\$ / \mathrm{kWh})$
$\$ 0.06886$
$\$ 0.04533$
$\$ 0.03369$

Demand $(\$ / \mathrm{kW})$

$\$ 13.39$

$\$ 1.24$

$\begin{array}{ll}\text { Energy ( } \$ / \text { thurm) } & \\ \text { s0.30895 } & 0.107 \text { thorm/kWh } \\ \$ 0.36622 & 1,032 \text { Btu/cuft HHV } \\ & 928.8 \text { Btu/cuft LHV }\end{array}$

G.4 
TABLE G.2. Energy Analysis for Scenario 2 (contd)

\begin{tabular}{|c|c|c|c|c|c|c|c|}
\hline \multicolumn{2}{|c|}{ Natural Gas Consumed: } & \multirow{2}{*}{$\begin{array}{l}\text { Enorgy } \\
165,314\end{array}$} & \multirow[t]{2}{*}{ (therms/yr) } & \multirow{2}{*}{$\begin{array}{l}\text { Value } \\
\$ 51,074\end{array}$} & \multirow[t]{2}{*}{$(\$ / y T)$} & & \\
\hline Winter & Cogen Rato & & & & & & \\
\hline & Non-cogen Rate & 22,604 & & $\$ 8,278$ & & & \\
\hline & sub-total & 187,918 & & $\$ 59,352$ & & & \\
\hline \multirow[t]{3}{*}{ Summer } & Cogen Rate & 336,532 & & $\$ 102,221$ & & & \\
\hline & Non-cogen Rate & 46,015 & & $\$ 16,190$ & & & \\
\hline & sub-total & 382,546 & & $\$ 118,412$ & & & \\
\hline \multicolumn{2}{|l|}{ Total } & 570,464 & & $\$ 177,763$ & & & \\
\hline \multicolumn{2}{|c|}{ Electricity Generated: } & Energy & $(k W h / y r)$ & Domand & $(\mathrm{kW})$ & & \\
\hline \multirow[t]{3}{*}{ Summer } & On-Poak & 836,976 & & 1,200 & & & \\
\hline & Somi-Poak & $1,076,112$ & & 1,200 & & & \\
\hline & Off-Poak & 0 & & & . & & \\
\hline \multirow[t]{3}{*}{ Winter } & On-Peak & 504,216 & & 1,200 & & & \\
\hline & Somi-Poak & $2,184,236$ & & 1,200 & & & \\
\hline & Off-Peak & 0 & & & ' & & \\
\hline \multicolumn{2}{|c|}{ Not Electricity Genorated: } & Enorgy & $(\mathrm{kWh} / \mathrm{yr})$ & Domand & $(\mathrm{kW})$ & Value & $(\$ / y r)$ \\
\hline \multirow[t]{4}{*}{ Summer } & On-Poak & 826,514 & & 1,185 & & $\$ 136,249$ & \\
\hline & Somi-Poak & $1,062,661$ & & 1,185 & & $\$ 55,517$ & \\
\hline & Off-Peak & 0 & & $\cdot$ & & so & \\
\hline & sub-total & $1,889,174$ & & & & $\$ 191,767$ & \\
\hline \multirow[t]{4}{*}{ Winter } & On-Peak & 497,913 & & 1,185 & & $\$ 48,726$ & \\
\hline & Somi-Poak & $2,157,624$ & & 1,185 & & $\$ 93,656$ & \\
\hline & Otf-Poak & 0 & & & & so & \\
\hline & sub-total & $2,655,538$ & & & & $\$ 142,383$ & \\
\hline \multicolumn{2}{|l|}{ Total } & $4,544,712$ & & & & $\$ 334,150$ & \\
\hline \multirow{2}{*}{\multicolumn{2}{|c|}{ Thermal Energy Recoverable: }} & Summer & & Winter & & Total & \\
\hline & & 112,363 & therms/yr & 157,944 & therms/yr & 270,307 & therms/yr \\
\hline \multicolumn{2}{|c|}{ Required Thermal Energy: } & Summer & (therms/yr) & Winter & (therms/yr) & Total & (therms/yr) \\
\hline & Cooling & 176,330 & & 234,460 & & 410,790 & \\
\hline & Hoating & 0 & & 0 & & 0 & \\
\hline ' & Ro-Hoat & 0 & & 0 & & 0 & \\
\hline & DHW & 4,183 & & 5,797 & & 9,980 & \\
\hline & sub-total & 180,513 & & 240,257 & & 420,770 & \\
\hline
\end{tabular}


TABLE G.2. Energy Analysis for Scenario 2 (contd)

Thermal Energy Rocoverable \& Useable:

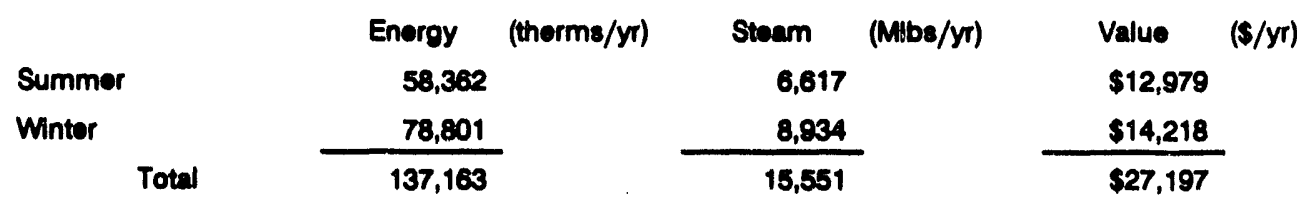

Summary of Caloulations:

Natural Ges Fuel Cost

Electrical Savings

SDG\&E Back-up Cost

Thermal Savinge

Not Energy Savinge

Average SDG\&E/FERC Efficiency
$(\$ 177,703) / y r$

$\$ 334,150 / y r$

$(\$ 30,888) / y T$

$\$ 27,197 / y r$

$152,695 / y r$

$43.57 \%$
42.5\% or greater required for cogen gas rate Doses qualify for cogen gas rate. 
TABLE G.3. Energy Analysis for Scenario 3

Rociprocating Engirie Data: Number of Engines Generator Capacity Contracted Domand Heat Rate (HHM) Thermal Recovery

Operating Schedule:

On-Poak

Somi-Poak

Off-Peak

Available Operating Hours

Scheduled Downtime

Not Operating Hours Not Utilization of Hours Load Utilization Factor Powerhouse Load

Electric Rate Schedule:

Summer

$$
\text { On-Peak }
$$

Semi-Peak

Off-Peak sub-total

Winter

$$
\text { On-Poak }
$$

Somi-Peak

Off-Poak sub-total Total

Natural Gas Rato Schedule:

\section{Winter Cogen Rate} Non-cogen Rate

\section{Summer Cogen Rate} Non-cogen Rate

Steam Rate Schedule:

Summer Marginal Rate

Winter Marginal Rate

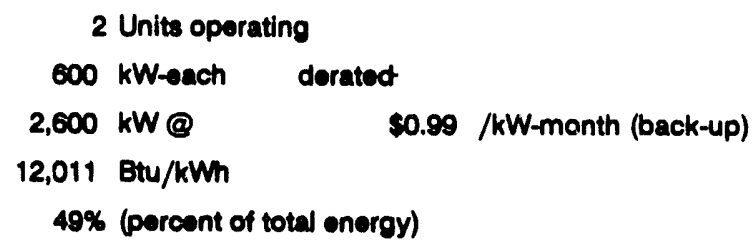

$\begin{array}{cc}\text { Summor } & \text { Winter } \\ Y & \text { i } \\ N & N \\ N & N\end{array}$

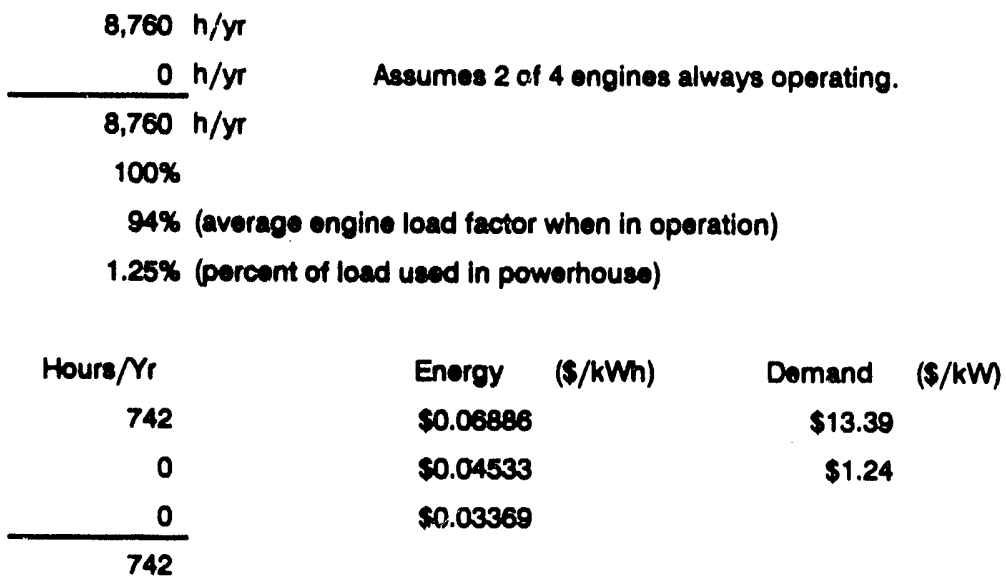

$\begin{array}{r}447 \\ 0 \\ 0 \\ \hline 447 \\ \hline 1,189\end{array}$

$\$ 0.06171$

$\$ 2.17$

$\$ 0.03864$

$\$ 1.24$

$\$ 0.03186$

Hours/Yr

252

Enorgy

(\$/therm)

$\$ 0.30895$

0.107 therm $/ \mathrm{kWh}$

252

$\$ 0.36622$

1,032 Btu/cuft HHV

928.8 Btu/cuft LHV .

G.7 
TABLE G.3. Energy Analysis for Scenario 3 (contd)

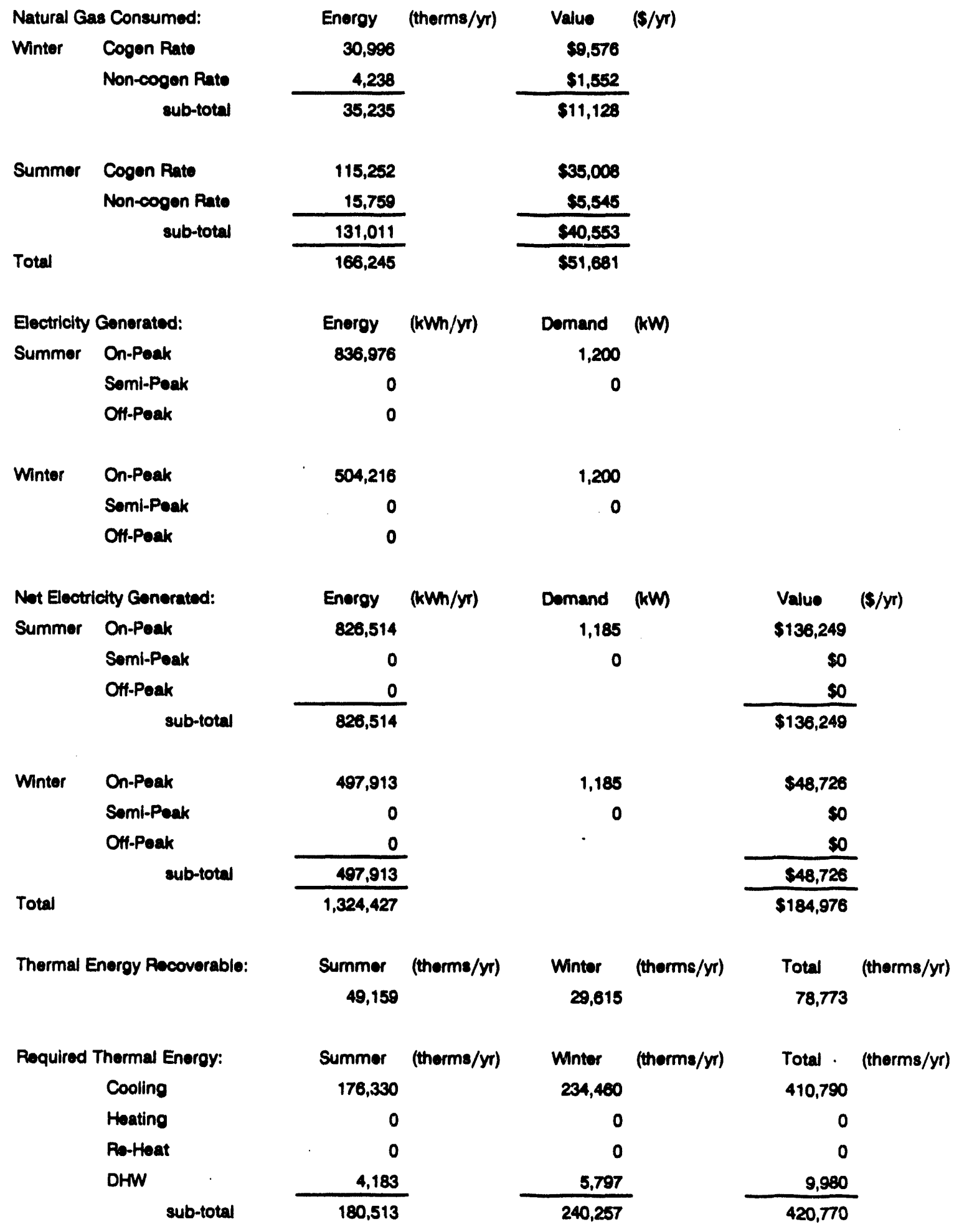

G.8 
TABLE G.3. Energy Analysis for Scenario 3 (contd)

Thermal Energy Recoverable \& Useable:

\begin{tabular}{|c|c|c|c|c|c|}
\hline & Energy & (therms/yr) & Stoam & (Mlbs/yr) & Value \\
\hline Summor & 25,533 & & 2,895 & & $\$ 5,678$ \\
\hline Winter & 14,775 & & 1,675 & & $\$ 2,666$ \\
\hline Total & 40,309 & & 4,570 & & $\$ 8,344$ \\
\hline
\end{tabular}

Summary of Calculations:

Natural Gas Fuel Cost

Electrical Savings

SDG\&E Back-up Cost

Thermal Savings

Net Energy Savings

Average SDG\&E/FERC Efficiency
$(\$ 51,681) / y r$

$\$ 184,976 / y r$

$(\$ 30,888) / y T$

$\$ 8,344 / y r$

$110,751 / y r$

$43.68 \%$
42.5\% or greater required for cogen gas rate Does quality for cogen gas rate.

G.9 
TABLE G.4. Energy Analysis for Scenario 4

Rociprocating Engine Data: Number of Engines Gonerator Capacity Contracted Domand Hoat Rate (HHM) Thermal Recovery

Oporating Schodule:

On-Poak

Somi-Poak

Off-Peak

Avallable Operating Hours

Scheduled Downtime

Not Operating Hours

Not Utilization of Hours

Load Utilization Factor

Powerhouse Load

Electric Rate Schodule:
Summer $\begin{aligned} & \text { On-Poak } \\ & \text { Semi-Poak } \\ & \text { Off-Poak } \\ & \text { sub-total }\end{aligned}$
Wnter On-Peak
Somi-Poak
Ofi-Poak
sub-total
Total

Natural Gas Rate Schodulo:

Winter

Cogen Rate

Non-cogen Rate

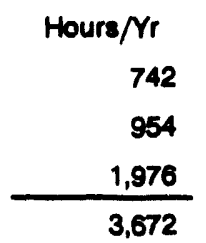

$600 \mathrm{~kW}$-each

2,600kW@

$\$ 0.90 / k W$-month (back-up)

12,011 Btu/kWh

49\% (percent of total enorgy)

$\begin{array}{cc}\text { Summer } & \text { Wintor } \\ Y & Y \\ Y & Y \\ Y & Y\end{array}$

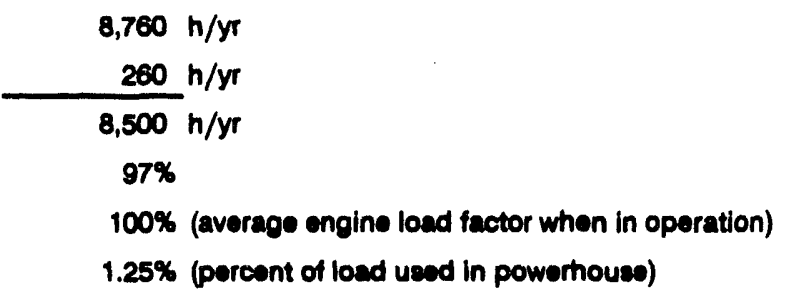

$\begin{array}{ll} & \text { Non-cogen Rate } \\ \text { Summer } & \text { Cogen Rate } \\ \text { Non-cogen Rate }\end{array}$

Steam Rate Schedule:

Summer Marginal Rate

Winter Marginal Rato

$\begin{array}{r}447 \\ 1,837 \\ 2,704 \\ \hline 5,088 \\ \hline 8,760\end{array}$

$\$ 0.08171$

$\$ 2.17$

$\$ 0.03864$

$\$ 1.24$

$\$ 0.03186$

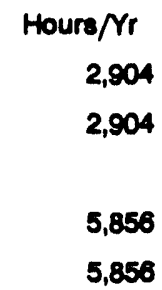

Hours/Yr

3,672

5,088

Enorgy (\$/therm)
$\$ 0.30895$
$\$ 0.36622$
$\$ 0.30375$
$\$ 0.35185$
Energy (\$/therm)
$\$ 0.222$
$\$ 0.180$

G.10 
TABLE G.4. Energy Analysis for Scenario 4 (contd)

\begin{tabular}{|c|c|c|c|c|c|c|c|}
\hline \multicolumn{2}{|c|}{ Natural Gas Consumed: } & \multirow{2}{*}{$\begin{array}{l}\text { Energy } \\
0\end{array}$} & \multirow[t]{2}{*}{ (therms/yr) } & \multirow{2}{*}{$\begin{array}{l}\text { Value } \\
\text { so }\end{array}$} & \multirow[t]{2}{*}{$(\$ / y r)$} & & \\
\hline Winter & Cogen Rate & & & & & & \\
\hline & Non-cogen Rate & 838,265 & & $\$ 306,980$ & & & \\
\hline & sub-total & 838,265 & & $\$ 308,900$ & & & \\
\hline \multirow[t]{3}{*}{ Summer } & Cogen Rate & 0 & & So & & & \\
\hline & Non-cogen Rate & $1,690,386$ & & $\$ 594,762$ & & & \\
\hline & sub-total & $1,690,386$ & & $\$ 594,762$ & & & \\
\hline \multicolumn{2}{|l|}{ Total } & $2,528,652$ & & $\$ 901,752$ & & & \\
\hline \multicolumn{2}{|c|}{ Electricity Generated: } & Energy & $(\mathbf{k W h} / \mathbf{y r})$ & Domand & (kW) & & \\
\hline \multirow[t]{3}{*}{ Summer } & On-Poak & $1,727,945$ & & 2,400 & & & \\
\hline & Somi-Poak & $2,221,644$ & & 2,400 & & & \\
\hline & Ott-Poak & $4,601,644$ & & $\cdot$ & & & \\
\hline \multirow[t]{3}{*}{ Winter } & On-Poak & $1,040,959$ & & 2,400 & & & \\
\hline & Somi-Poak & $4,510,8228$ & & 2,400 & & & \\
\hline & Otf-Poak & $6,296,986$ & & & & & \\
\hline \multicolumn{2}{|c|}{ Not Electricity Gonorated: } & Enorgy & $(\mathbf{k W h} / \mathbf{y r})$ & Domand & (kW) & Value & $(\$ / y r)$ \\
\hline \multirow[t]{4}{*}{ Summer } & On-Peak & $1,706,346$ & & 2,370 & & $\$ 276,170$ & \\
\hline & Somi-Poak & $2,193,873$ & & 2,370 & & $\$ 114,142$ & \\
\hline & Oft-Peak & $4,544,123$ & & & & $\$ 153,092$ & \\
\hline & sub-total & $8,444,342$ & & & & $\$ 543,404$ & \\
\hline \multirow[t]{4}{*}{ Winter } & On-Peak & $1,027,947$ & & 2,370 & & $\$ 99,435$ & \\
\hline & Somi-Poak & $4,454,437$ & & 2,370 & & $\$ 192,691$ & \\
\hline & Off-Poak & $6,218,274$ & & & & $\$ 198,114$ & \\
\hline & sub-total & $11,700,658$ & & & & $\$ 490,240$ & \\
\hline \multicolumn{2}{|l|}{ Total } & $20,145,000$ & & & & $\$ 1,033,644$ & \\
\hline \multirow{2}{*}{\multicolumn{2}{|c|}{ Thermal Energy Recoverable: }} & Summer & & Winter & & Total & \\
\hline & & 502,246 & therms/yr & 695,923 & therms/yr & $1,198,169$ & therms/yr \\
\hline \multicolumn{2}{|c|}{ Required Thermal Energy: } & Summer. & (therms/yr) & Winter & (therms/yr) & Total & (therms/yr) \\
\hline & Cooling & 176,330 & & 234,460 & & 410,790 & \\
\hline & Hoating & 0 & & 0 & & 0 & \\
\hline & Re-Heat & 0 & & 0 & & 0 & \\
\hline & DHW & 4,183 & & 5,797 & & 9,980 & \\
\hline & sub-total & 180,513 & & 240,257 & & 420,770 & \\
\hline
\end{tabular}


TABLE G.4. Energy Analysis for Scenario 4 (contd)

Thermal Energy Recoverable \& Useable:

\begin{tabular}{|c|c|c|c|c|c|}
\hline & Energy & (therms/yr) & Steam & (Mibs/yr) & Value \\
\hline Summer & 175,156 & & 19,850 & & $\$ 38,951$ \\
\hline Winter & 233,126 & & 26,431 & & $\$ 42,063$ \\
\hline Total & 408,281 & & 46,200 & & $\$ 81,014$ \\
\hline
\end{tabular}

Summary of Calculations:

$\begin{array}{lr}\text { Natural Gas Fual Cost } & (\$ 201,752) / y r \\ \text { Electrical Savings } & \$ 1,033,644 / \mathbf{~ r r} \\ \text { SDG\&E Back-up Cost } & (\$ 30,888) / y r \\ \text { Thermal Savings } & \$ 81,014 / \mathrm{yr} \\ \text { Not Energy Savings } & 182,018 / \mathrm{yr}\end{array}$

Average SDG\&E/FERC Efficioncy $39.18 \%$

42.5\% or greater required for cogen gas rate Does not qualify for cogen gas rate.

G.12 
TABLE G.5. Energy Analysis for Scenario 5

Reciprocating Engine Data:

Number of Engines

Gonerator Capacity

Contracted Domand

Hoat Rato (HHM)

Thermal Rocovery

Operating Schedule:

On-Poak

Somi-Poak

Otf-Peak

Avallable Operating Hours

Schoduled Downtime

Not Operating Hours

Not Utilization of Hours

Load Utilization Factor

Powerhouse Load

4 Units operating

$600 \mathrm{~kW}$-each derated

2,600 kW@

s0.99 /kW-month (back-up)

12,011 Btu/kWn

49\% (percont of total energy)

$\begin{array}{cc}\text { Summor } & \text { Winter } \\ \mathbf{Y} & \mathbf{Y} \\ \mathbf{Y} & \mathrm{Y} \\ \mathbf{N} & \mathrm{N}\end{array}$

$8,760 \mathrm{~h} / \mathrm{yr}$

$260 \mathrm{~h} / \mathrm{yr}$

$8,500 \mathrm{~h} / \mathrm{yr}$

97\%

$100 \%$ (average engine load factor when in operation)

$1.25 \%$ (percont of load used in powerhouse)

Electric Rate Schodule:

Summer On-Poak

Somi-Poak

Off-Peak

sub-total

Winter

$$
\text { On-Poak }
$$

Somi-Poak

Ott-Poak

sub-total

Total

Natural Gas Rate Schedule:

Winter

Cogen Rate

Non-cogen Rate

Summer

Cogen Rate

Non-cogen Rate
Hours/Yr

742

954

0

Energy (\$/kWh)

50.06886

$\$ 0.04533$

$\$ 0.03369$

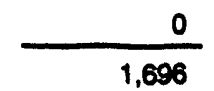

$\$ 0.08171$

$\$ 0.03864$

$\$ 0.03186$
$\$ 2.17$

$\$ 1.24$

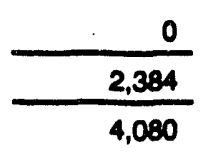

Hours/rr

1,344

1,344

2,736

2,736

1,696

2,384

4,080

$\begin{array}{r}1,686 \\ 2,384 \\ \hline 4,080\end{array}$

Enorgy (\$/therm)

\$0.30895

s0.3662?

$\$ 0.30375$

$\$ 0.35185$

Summer Marginal Rato

Winter Marginal Rate

$\$ 0.222$

$\$ 0.180$

G.13 
TABLE G.5. Energy Analysis for Scenarlo 5 (contd)

\begin{tabular}{|c|c|c|c|c|c|c|c|}
\hline \multicolumn{2}{|c|}{ Natural Gas Consumed: } & \multirow{2}{*}{$\begin{array}{l}\text { Enorgy } \\
0\end{array}$} & \multirow[t]{2}{*}{ (therms/yr) } & \multirow{2}{*}{$\begin{array}{l}\text { Value } \\
\qquad \$ 0\end{array}$} & \multirow[t]{2}{*}{$(\$ / y \boldsymbol{r})$} & & \\
\hline Winter & Cogen Rate & & & & & & \\
\hline & Non-cogen Rate & 387,958 & & $\$ 142,078$ & & & \\
\hline & sub-total & 387,958 & & $\$ 142,078$ & & & \\
\hline \multirow[t]{3}{*}{ Summer } & Cogen Rate & 0 & & so & & & \\
\hline & Non-cogen Rato & 789,771 & & $\$ 277,881$ & & & \\
\hline & sub-total & 789,771 & & $\$ 277,881$ & & & \\
\hline \multicolumn{2}{|l|}{ Total } & $1,177,728$ & & $\$ 19,850$ & & & \\
\hline \multicolumn{2}{|c|}{ Electricity Generated: } & Energy & $(\mathbf{k W h} / \mathbf{y r})$ & Domand & (kW) & & \\
\hline \multirow[t]{3}{*}{ Summer } & On-Poak & $1,727,945$ & & 2,400 & & & \\
\hline & Semi-Poak & $2,221,644$ & & 2,400 & & & \\
\hline & Ott-Poak & 0 & & & & & \\
\hline \multirow[t]{3}{*}{ Winter } & On-Peak & $1,040,959$ & & 2,400 & & & \\
\hline & Somi-Poak & $4,510,822$ & & 2,400 & & & \\
\hline & Off-Poak & 0 & & & & & \\
\hline \multicolumn{2}{|c|}{ Not Electricty Generated: } & Enorgy & $(k W h / y r)$ & Domand & (kW) & Value & $(\$ / y r)$ \\
\hline \multirow[t]{4}{*}{ Summer } & On-Poak & $1,706,346$ & & 2,370 & & $\$ 276,170$ & \\
\hline & Somi-Poak & $2,193,873$ & & 2,370 & & $\$ 114,142$ & \\
\hline & Otf-Peak & 0 & & & & so & \\
\hline & sub-total & $3,900,219$ & & & & $\$ 390,313$ & \\
\hline \multirow[t]{4}{*}{ Winter } & On-Poak & $1,027,947$ & & 2,370 & & $\$ 99,435$ & \\
\hline & Soml-Poak & $4,454,437$ & & 2,370 & & $\$ 192,691$ & \\
\hline & Off-Peak & 0 & & & & so & \\
\hline & sub-total & $5,482,384$ & & & & $\$ 292,126$ & \\
\hline Total & & $9,382,603$ & & & & $\$ 682,439$ & \\
\hline \multirow{2}{*}{\multicolumn{2}{|c|}{ Thermal Enorgy Recoverable: }} & Summer & & Wintor & & Total & \\
\hline & & 231,974 & therms/yr & 326,077 & therms/yr & 558,051 & therms/yr \\
\hline \multicolumn{2}{|c|}{ Required Thermal Enorgy: } & Summer & (therms/yr) & Winter & (therms/yr) & Total & (therms/yr) \\
\hline & Cooling & 176,330 & & 234,460 & & 410,790 & \\
\hline & Hoating & 0 & & 0 & & 0 & \\
\hline & Po-Hoat & 0 & & 0 & & 0 & \\
\hline & DHW & 4,183 & & 5,797 & & 9,980 & \\
\hline & sub-total & 180,513 & & 240,257 & & 420,770 & \\
\hline
\end{tabular}

G.14 
TABLE G.5. Energy Analysis for Scenario 5 (contd)

Thermal Energy Recoverable \& Useable:

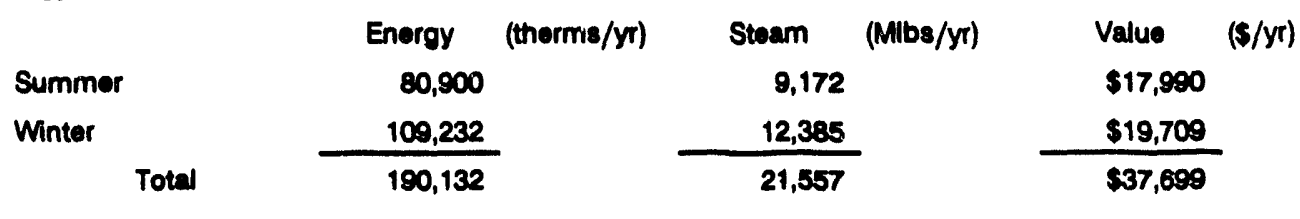

Summary of Calculations:

Natural Gas Fuel Cost
Electrical Savings
SDG\&E Back-up Cost
Thermal Savings
Not Energy Savings

Average SDG\&E/FERC Efficiency

$$
\begin{aligned}
& (\$ 419,959) / y r \\
& \$ 682,439 / y r \\
& (\$ 30,888) / y r \\
& \$ 37,699 / y r \\
& 269,291 / y r
\end{aligned}
$$

$39.18 \%$
42.5\% or greater required for cogen gas rate Does not qualify for cogen gas rate. 
TABLE G.6. Energy Analysis for Scenario 6

Reciprocating Engine Data:

Number of Engines

Gonerator Capacity

Contracted Demand

Hoat Rato (HHM)

Thermal Recovery

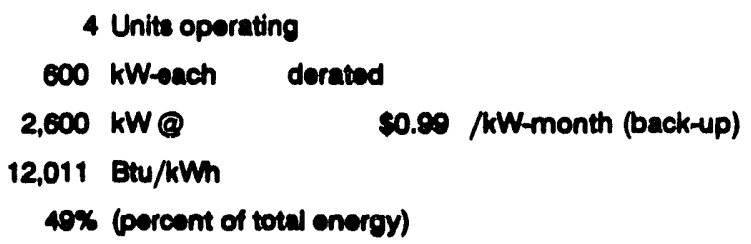

Operating Schedule:

On-Pank

Semifoak

Olf-Paak

$\begin{array}{cc}\text { Summer } & \text { Winter } \\ \mathbf{Y} & \mathbf{Y} \\ \mathbf{N} & \mathrm{N} \\ \mathbf{N} & \mathrm{N}\end{array}$

Avaliable Operating Houre

Scheduled Downtime

Not Oporating Hours

Not Utilization of Houre

Load Utillzation Factor

Powerhouse Loed

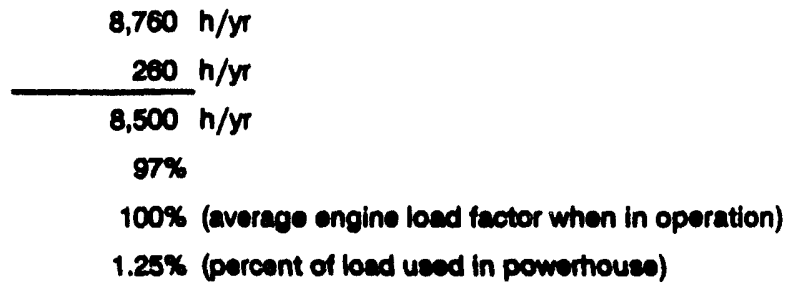

Eectric Rate Schedulo:

Summer

$$
\text { On-Poak }
$$

Somi-Poak

Otf-Peak

sub-total

Houre/ $/ r$

742

o

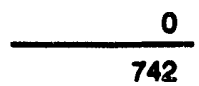

Winter

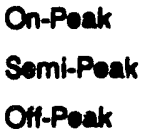

OH-Poak

sub-total

Total

Natural Gas Rats Schedule:

Winter Cogen Rato

Non-cogen Rate

Summer Cogen Rato

Non-cogen Rate

Staam Rate Schedule:

Summer Marginal Rate

Winter

Marginal Rato

$\begin{array}{r}447 \\ 0 \\ 0 \\ \hline 447 \\ \hline 1,189\end{array}$

Hours/Yr

252

252

937

937

Hours/Yr
$742 \mathrm{hro} / \mathrm{yr}$

$447 \mathrm{hre} / \mathrm{yr}$

$1,189 \mathrm{hrs} / \mathrm{yr}$

$\$ 0.30375$

$\$ 0.35185$
Energy ( $\$ /$ therm)

s0.222 / therm

$\$ 0.180$ /thorm
$\$ 0.08171$

$\$ 2.17$

s0.03884

$\$ 1.24$

$\$ 0.03186$

\begin{tabular}{|c|c|}
\hline $\begin{array}{l}\text { Enorgy (\$/kWh) } \\
\text { so.0688s }\end{array}$ & $\begin{array}{l}\text { Domand } \\
\$ 13.39\end{array}$ \\
\hline$\$ 0.04533$ & $\$ 1.24$ \\
\hline \multicolumn{2}{|l|}{50.03300} \\
\hline$\$ 0.08171$ & $\$ 2.17$ \\
\hline s0.038s4 & $\$ 1.24$ \\
\hline 0.03186 & \\
\hline
\end{tabular}

Energy ( $\$ /$ therm)

so.30895

0.107 therm $/ \mathrm{kWh}$

$\$ 0.36822$

1,032 Btu/cuft HHV

928.8 Btu/cutt LHV $(s / \mathrm{kW})$

G. 16 
TABLE G.6. Energy Analysis for Scenario 6 (contd)

\begin{tabular}{|c|c|c|c|c|c|c|c|}
\hline \multicolumn{2}{|c|}{ Natural Gas Consumed: } & \multirow{2}{*}{$\begin{array}{l}\text { Enorgy } \\
0\end{array}$} & \multirow[t]{2}{*}{ (therms/yr) } & \multirow{2}{*}{$\begin{array}{l}\text { Value } \\
\qquad \mathbf{S}\end{array}$} & \multirow[t]{2}{*}{$(\$ / y r)$} & & \\
\hline Wintor & Cogen Rate & & & & & & \\
\hline & Non-cogen Rate & 72,742 & & $\$ 26,640$ & & & \\
\hline & sub-total & 72,742 & & $\$ 28,640$ & & & \\
\hline & & & & $\cdot$ & & & \\
\hline \multirow[t]{3}{*}{ Summer } & Cogen Rate & 0 & & SO & & & \\
\hline & Non-cogen Rate & 270,473 & & $\$ 95,168$ & & & \\
\hline & sub-total & 270,473 & & $\$ 95,166$ & & & \\
\hline \multicolumn{2}{|l|}{ Total } & 343,215 & & $\$ 121,806$ & & & \\
\hline \multicolumn{2}{|c|}{ Electricity Generated: } & Energy & $(\mathbf{k W h} / \mathbf{y r})$ & Domand & (km) & & \\
\hline \multirow[t]{3}{*}{ Summer } & On-Peak & $1,727,945$ & & 2,400 & & & \\
\hline & Somi-Paak & 0 & & 0 & & & \\
\hline & Off-Poak & 0 & & & & & \\
\hline \multirow[t]{3}{*}{ Winter } & On-Poak & $1,040,959$ & & 2,400 & & & \\
\hline & Somi-Poak & 0 & & 0 & & & \\
\hline & Off-Peak & 0 & & & & & \\
\hline \multicolumn{2}{|c|}{ Not Electricity Genorated: } & Enorgy & $(k W h / y r)$ & Demand & (km) & Value & $(\$ / y r)$ \\
\hline \multirow[t]{4}{*}{ Summer } & On-Poak & $1,706,346$ & & 2,370 & & $\$ 276,170$ & \\
\hline & Somi-Poak & 0 & & 0 & & so & \\
\hline & Off-Peak & 0 & & & & so & \\
\hline & sub-total & $1,706,346$ & & $\cdot$ & & $\$ 276,170$ & \\
\hline \multirow[t]{4}{*}{ Winter } & On-Poak & $1,027,947$ & & 2,370 & & $\$ 99,435$ & \\
\hline & Somi-Poak & 0 & & 0 & & so & \\
\hline & Off-Poak & 0 & & & & so & \\
\hline & sub-total & $1,027,947$ & & & & $\$ 90,435$ & \\
\hline Total & & $2,734,293$ & & & & $\$ 375,605$ & \\
\hline \multirow{2}{*}{\multicolumn{2}{|c|}{ Thermal Energy Racoverable: }} & Summer & & Winter & & Total & \\
\hline & & 101,489 & therms/yr & 61,139 & thorms/yr & 162,628 & therms/yr \\
\hline \multicolumn{2}{|c|}{ Required Thermal Energy: } & Summer & (therms/yr) & Winter & (therms/yr) & Total & (therms/yr) \\
\hline & Cooling & 176,330 & & 234,460 & & 410,790 & \\
\hline & Heating & 0 & & 0 & & 0 & \\
\hline & Pa-Heat & 0 & & 0 & & 0 & \\
\hline & DHW & 4,183 & & 5,797 & & 9,980 & \\
\hline & sub-total & 180,513 & & 240,257 & & 420,770 & \\
\hline
\end{tabular}


TABLE G.6. Energy Analysis for Scenario 6 (contd)

Thermal Energy Recoverable \& Usoable:

\begin{tabular}{|c|c|c|c|c|c|}
\hline & Energy & (therms/yr) & Steam & (Mibs/yr) & Value \\
\hline Summer & 35,394 & & 4,013 & & $\$ 7,871$ \\
\hline Wintor & 20,481 & & 2,322 & & $\$ 3,695$ \\
\hline Total & 55,875 & & 6,335 & & $\$ 11,568$ \\
\hline
\end{tabular}

Summary of Calculations:

$\begin{array}{lr}\text { Natural Gas Fuel Cost } & (\$ 121,806) / y r \\ \text { Electrical Savings } & \$ 375,605 / y \\ \text { SDG\&E Back-up Cost } & (\$ 30,888) / y r \\ \text { Thermal Savings } & \$ 11,566 / y r \\ \text { Not Energy Savings } & 234,478 / y r\end{array}$

Averago SDG\&E/FERC Efficiency $\quad 39.26 \%$
42.5\% or greater required for cogen gas rate Dose not quality for cogen gas rate.

G.18 
TABLE G.7. Energy Analysis for Scenario 7

Rociprocating Engine Data:

Number of Engines

Gonorator Capacity

Contracted Domand

Heat Rate (HHM)

Thermal Recovery

Operating Schedule:

On-Poak

Somi-Poak

OH-Poak

Available Operating Hours

Scheduled Downtime

Not Operating Hours

Not Utilization of Hours

Load Utilization Factor

Powerhouse Loed

Electric Rate Schedule:

Summor On-Peak

Somi-Poak

OH-Peak

sub-total

Hours/Yr

742

954

$\frac{1,976}{3,672}$

$\frac{1,976}{3,672}$

Winter

On-Poak

Semi-Poak

Otf-Poak

sub-total

Total

Natural Gas Rate Schedule:

Winter Cogen Rato

Non-cogen Rate

Summer Cogen Rato

Non-cogen Rate

Steam Rate Schedule:

Summor Marginal Rato

Winter Marginal Rate

Hours/ $\mathrm{Yr}$

2,904

2,904

$\begin{array}{cc}\text { Summer } & \text { Winter } \\ Y & Y \\ Y & Y \\ Y & Y\end{array}$

$8,760 \mathrm{~h} / \mathrm{yr}$

$260 \mathrm{~h} / \mathrm{yr}$

$8,500 \mathrm{~h} / \mathrm{yr}$

$97 \%$

$100 \%$ (average engine load factor when in operation)

$1.25 \%$ (percent of losd used in powerhouse)

4 Units operating

\$0.99 /kW-month (back-up)

$500 \mathrm{Btu} / \mathrm{kWh}$

$38 \%$ (porcent of total energy)

$Y$

$\begin{array}{r}447 \\ 1,937 \\ 2,704 \\ \hline 5,088 \\ \hline 8,760\end{array}$

$\$ 0.08171$

$\$ 2.17$

$\$ 0.03864$

$\$ 1.24$

$\$ 0.03186$

Energy $(\$ /$ therm $)$

$\$ 0.30895$

$\$ 0.36622$

0.107 therm $/ \mathrm{kWh}$

1,032 Btu/cuft HHV

928.8 Btu/cuft LHV $\underset{\$ 13.39}{ }(\$ / \mathrm{kW})$

$\$ 1.24$

G.19

$\$ 0.30375$

$\$ 0.35185$

Hours $/ \mathrm{Yr}$

3,672

Energy (\$/thorm)

$\$ 0.222$

$\$ 0.180$

$\frac{5,088}{8,760}$

. 
TABLE G.7. Energy Analysis for Scenario 7 (contd)

\begin{tabular}{|c|c|c|c|c|c|c|c|}
\hline \multicolumn{2}{|c|}{ Natural Gas Consumed: } & \multirow{2}{*}{$\begin{array}{l}\text { Energy } \\
745,024\end{array}$} & \multirow[t]{2}{*}{ (therms/yr) } & \multirow{2}{*}{$\begin{array}{l}\text { Value } \\
\$ 230,175\end{array}$} & \multirow[t]{2}{*}{$(\$ / y)$} & & \\
\hline \multirow[t]{3}{*}{ Winter } & Cogen Rate & & & & & & \\
\hline & Non-cogen Rate & 0 & & 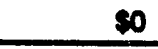 & & & \\
\hline & sub-total & 746,024 & & $\$ 230,175$ & & & \\
\hline \multirow[t]{3}{*}{ Summor } & Cogen Rate & $1,502,362$ & & $\$ 456,343$ & & & \\
\hline & Non-cogen Rate & 0 & & $s 0$ & & & \\
\hline & sub-total & $1,502,362$ & & $\$ 456,343$ & & & \\
\hline \multirow{2}{*}{\multicolumn{2}{|c|}{ Total }} & $2,247,386$ & & $\$ 686,518$ & & & \\
\hline & & & & $\cdot$ & & & \\
\hline \multicolumn{2}{|c|}{ Electricity Generated: } & Energy & $(\mathbf{k W h} / \mathbf{y r})$ & Domand & $(k W)$ & & \\
\hline \multirow[t]{3}{*}{ Summer } & On-Poak & $1,756,744$ & & 2,440 & & & \\
\hline & Somi-Poak & $2,258,671$ & & 2,440 & & & \\
\hline & Oti-Peak & $4,678,338$ & & & & & \\
\hline \multirow[t]{3}{*}{ Winter } & On-Peak & $1,058,308$ & & 2,440 & & & \\
\hline & Somi-Poak & $4,586,002$ & & 2,440 & & & \\
\hline & Off-Poak & $6,401,938$ & & & & . & \\
\hline \multicolumn{2}{|c|}{ Not Electricity Gonorated: } & Enorgy & $(\mathrm{kWn} / \mathrm{yr})$ & Domand & $(\mathrm{kW})$ & Value & $(\$ / y r)$ \\
\hline \multirow[t]{4}{*}{ Summer } & On-Poak & $1,734,785$ & & 2,410 & & $\$ 280,773$ & \\
\hline & Semi-Poak & $2,230,438$ & & 2,410 & & $\$ 116,045$ & \\
\hline & Off-Peak & $4,619,859$ & & & & $\$ 155,643$ & \\
\hline & sub-total & $8,585,082$ & & & & $\$ 552,461$ & \\
\hline \multirow[t]{4}{*}{ Winter } & On-Poak & $1,045,079$ & & 2,410 & & $\$ 101,092$ & \\
\hline & Somi-Poak & $4,528,677$ & & 2,410 & & $\$ 195,903$ & \\
\hline & Off-Poak & $6,321,912$ & & & & $\$ 201,416$ & \\
\hline & sub-total & $11,895,668$ & & $\cdot$ & & $\$ 498,411$ & \\
\hline \multicolumn{2}{|l|}{ Total } & $20,480,750$ & & & & $\$ 1,050,872$ & \\
\hline \multirow{2}{*}{\multicolumn{2}{|c|}{ Thermal Energy Rocoverable: }} & Summer & & Winter & & Total & \\
\hline & & 346,881 & therms/yr & 480,645 & therms/yr & 827,526 & therms/yr \\
\hline \multicolumn{2}{|c|}{ Roquired Thermal Energy: } & Summer & (therms/yr) & Winter & (therms/yr) & Total & (therms/yr) \\
\hline & Cooling & 176,330 & & 234,460 & & 410,790 & \\
\hline & Hoating & 0 & & 0 & & 0 & \\
\hline & Ro-Hoat & 0 & & 0 & & 0 & \\
\hline & DHW & 4,183 & & 5,797 & & 9,980 & \\
\hline & sub-total & 180,513 & & 240,257 & & 420,770 & \\
\hline
\end{tabular}


TABLE G.7. Energy Analysis for Scenario 7 (contd)

Thermal Energy Recoverable \& Usoable:

\begin{tabular}{|c|c|c|c|c|c|}
\hline & Enorgy & (therms/yr) & Stoam & (M/bs/yr) & Value \\
\hline Summor & 175,158 & & 19,850 & & $\$ 38,951$ \\
\hline Winter & 233,126 & & 26,431 & & $\$ 42,063$ \\
\hline Total & 408,281 & & 46,290 & & $\$ 81,014$ \\
\hline
\end{tabular}

Summary of Calculations:

Natural Gas Fuel Cost

Electrical Savings

SDG\&E Back-up Cost

Thermal Savings

Net Energy Savings

Average SDG\&E/FERC Efficiency

$$
\begin{array}{r}
(\$ 686,518) / y r \\
\$ 1,050,872 / y r \\
(\$ 28,987) / y r \\
\$ 81,014 / y r \\
416,381 / y r
\end{array}
$$

$44.65 \%$

\author{
42.5\% or greater required for cogen gas rate \\ Doses qualify for cogen gas rate.
}


TABLE G.8. Energy Analysis for Scenario 8

Reciprocating Engine Data: Number of Engines Generator Capacity Contracted Demand Hoat Rato (HHM) Thermal Rocovery

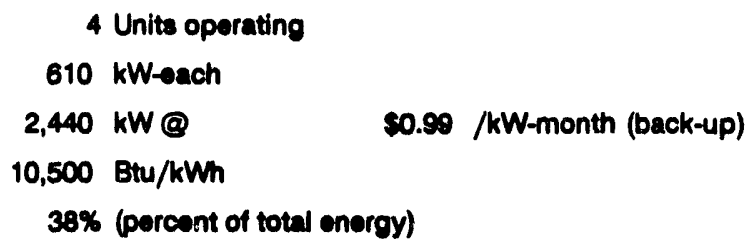

$\begin{array}{cc}\text { Summor } & \text { Winter } \\ Y & Y \\ Y & Y \\ N & N\end{array}$

$8,760 \mathrm{~h} / \mathrm{yr}$

$260 \mathrm{~h} / \mathrm{yr}$

$8,500 \mathrm{~h} / \mathrm{yr}$

$97 \%$

100\% (average engine load factor when in operation)

$1.25 \%$ (percent of load uead in powerhouse)

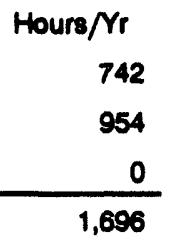

$\begin{array}{lr}\text { Energy }(\$ / k W h) & \text { Demand }(\$ / k W) \\ \$ 0.06886 & \$ 13.39 \\ \$ 0.04533 & \$ 1.24 \\ \$ 0.03369 & \end{array}$

$\$ 0.06171$

$\$ 2.17$

$\$ 0.03864$

$\$ 1.24$

$\$ 0.03188$

$\begin{array}{ll}\text { Energy (\$/therm) } & \\ \text { s0.30895 } & 0.107 \text { therm/kWh } \\ \text { s0.36822 } & 1,032 \text { Btu/cuft HHV } \\ & 928.8 \mathrm{Btu} / \text { cuft LHV }\end{array}$


TABLE G.8. Energy Analysis for Scenario 8 (contd)

\begin{tabular}{|c|c|c|c|c|c|c|c|}
\hline \multicolumn{2}{|c|}{ Natural Gas Consumed: } & \multirow{2}{*}{$\begin{array}{l}\text { Enorgy } \\
344,804\end{array}$} & \multirow[t]{2}{*}{ (therms/yr) } & \multirow{2}{*}{$\begin{array}{l}\text { Value } \\
\$ 106,527\end{array}$} & \multirow[t]{2}{*}{$(\$ / y r)$} & & \\
\hline \multirow[t]{3}{*}{ Winter } & Cogen Rate & & & & & & \\
\hline & Non-cogen Rate & 0 & & so & & & \\
\hline & sub-total & 344,804 & & $\$ 108,527$ & & & \\
\hline \multirow[t]{3}{*}{ Summer } & Cogen Rate & 701,923 & & $\$ 213,200$ & & & \\
\hline & Non-cogen Rate & 0 & & so & & & \\
\hline & sub-total & 701,923 & & $\$ 213,209$ & & & \\
\hline \multicolumn{2}{|l|}{ Total } & $1,046,728$ & & $\$ 319,737$ & & & \\
\hline \multicolumn{2}{|c|}{ Electricity Genorated: } & Energy & $(\mathrm{kWh} / \mathrm{yr})$ & Domand & (kW) & & \\
\hline \multirow[t]{4}{*}{ Summer } & On-Poak & $1,756,744$ & & 2,440 & & & \\
\hline & Soml-Poak & $2,258,671$ & & 2,440 & & & \\
\hline & Off-Peak & 0 & & & & & \\
\hline & & & & $\cdot$ & & & \\
\hline \multirow[t]{3}{*}{ Winter } & On-Peak & $1,058,308$ & & 2,440 & & & \\
\hline & Soml-Poak & $4,586,002$ & & 2,440 & & & \\
\hline & Ott-Poak & 0 & & & & & \\
\hline \multicolumn{2}{|c|}{ Not Electricity Generated: } & Enorgy & $(\mathrm{kWh} / \mathrm{yr})$ & Domand & $(\mathrm{kW})$ & Value & $(\$ / y r)$ \\
\hline \multirow[t]{4}{*}{ Summer } & On-Poak & $1,734,785$ & & 2,410 & & $\$ 280,773$ & \\
\hline & Somi-Poak & $2,230,438$ & & 2,410 & & $\$ 116,045$ & \\
\hline & Off-Poak & 0 & & & & so & \\
\hline & sub-total & $3,965,223$ & & & & $\$ 396,818$ & \\
\hline \multirow[t]{4}{*}{ Winter } & On-Peak & $1,045,079$ & & 2,410 & & $\$ 101,092$ & \\
\hline & Somi-Poak & $4,528,677$ & & 2,410 & & $\$ 195,903$ & \\
\hline & Off-Poak & 0 & & & & so & \\
\hline & sub-total & $5,573,757$ & & & & $\$ 296,995$ & \\
\hline Total & & $9,538,979$ & & & & $\$ 693,813$ & \\
\hline \multirow{2}{*}{\multicolumn{2}{|c|}{ Thermal Enorgy Rocoverable: }} & Summer & & Winter & & Total & \\
\hline & & 160,215 & therms/yr & $\begin{array}{c}225,208 \\
.\end{array}$ & therms/yr & 385,423 & therms/yr \\
\hline \multicolumn{2}{|c|}{ Required Thermal Enorgy: } & Summor & (therms/yr) & Winter & (thorms/yr) & Total & (therms/yr) \\
\hline & Cooling & 176,330 & & 234,460 & & 410,790 & \\
\hline & Heating & 0 & & 0 & & 0 & \\
\hline & Ro-Heat & 0 & & 0 & & 0 & \\
\hline & DHW & 4,183 & & 5,797 & & 9,980 & \\
\hline & aub-total & 180,513 & & 240,257 & & 420,770 & \\
\hline
\end{tabular}


TABLE G.8. Energy Analysis for Scenario 8 (contd)

Thermal Energy Ascoverable \& Useabie:

\begin{tabular}{|c|c|c|c|c|c|}
\hline & Enorgy & (therms/yr) & Steam & (M/bs/yr) & Value \\
\hline Summer & 80,800 & & 9,172 & & $\$ 17,990$ \\
\hline Wintor & 109,232 & & 12,385 & & $\$ 19,709$ \\
\hline Total & 190,132 & & 21,557 & & $\$ 37,699$ \\
\hline
\end{tabular}

Summary of Calculations:

Natural Gas Fuel Cost

Electrical Savings

SDG\&E Back-up Cost

Thermal Savings

Not Enorgy Savings

Averago SDG\&E/FERC Efficioncy
$(\$ 319,737) / y r$

$\$ 693,813 / y T$

$(\$ 28,987) / y r$

$\$ 37,699 / y T$

$382,788 / y r$

$44.65 \%$
42.5\% or greater required for cogen gas rato Dose quality for cogen gas rate. 
TABLE G.9. Energy Analysis for Scenario 9

Rociprocating Engine Data:

Number of Engines

Generator Capacity

Contracted Domand

Hoat Rate (HHM)

Thermal Racovery

Operating Schedule:

On-Poak

Somi-Poak

Off-Poak

Avallable Cporating Hours

Scheduled Downtime

Not Oporating Hours

Not Utilization of Hours

Load Utilization Factor

Powerhouse Load

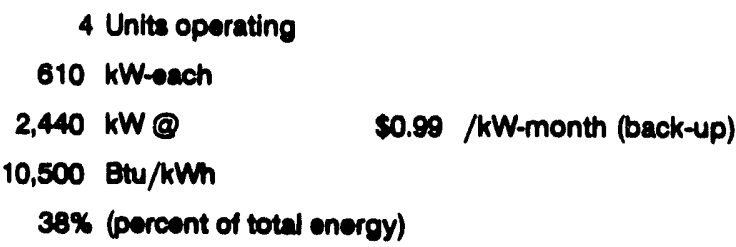

$\begin{array}{cc}\text { Summer } & \text { Wintor } \\ \text { Y } & \text { Y } \\ \text { N } & \text { N } \\ \text { N } & \text { N }\end{array}$

$8,760 \mathrm{~h} / \mathrm{yr}$

$260 \mathrm{~h} / \mathrm{yr}$

$8,500 \mathrm{~h} / \mathrm{yr}$

$97 \%$

$100 \%$ (average engine load factor when in operation)

1.25\% (percent of load used in powerhouse)

Electric Rato Schodule:

Summer On-Poak

Somi-Poak

Off-Peak

sub-total

Hours/Yr

742

0

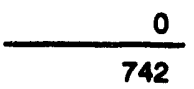

Winter

$$
\text { On-Poak }
$$

Semi-Peak

Off-Peak

sub-total

Total

Natural Gas Rate Schedule:

Winter

Cogen Rate

Non-cogen Rate

Summer Cogen Rato

Non-cogen Rate

Steam Rate Schedule:

Summer Marginal Rate

Winter Marginal Rate

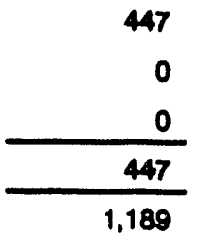

Houre/Yr

252

252

937

837

Hours/Yr

742

447

\begin{tabular}{|c|c|}
\hline Energy (\$/kWh) & Domand $(\$ / \mathrm{kW})$ \\
\hline S0.06886 & $\$ 13.39$ \\
\hline 0.04533 & $\$ 1.24$ \\
\hline
\end{tabular}

$\$ 0.03369$

S0.03171

$\$ 2.17$

$\$ 0.03884$

$\$ 1.24$

$\$ 0.03186$

\section{Enorgy ( $\$ /$ therm)}

S0.30895

\$0.36822

0.107 therm/kWh

1,032 Btu/cuft HHV

928.8 Btu/cuft LHV 


\begin{tabular}{|c|c|c|c|c|c|c|c|}
\hline \multicolumn{2}{|c|}{ Natural Gas Consumed: } & \multirow{2}{*}{$\begin{array}{l}\text { Energy } \\
64,651\end{array}$} & \multirow[t]{2}{*}{ (therms/yr) } & \multirow{2}{*}{$\begin{array}{l}\text { Value } \\
\$ 19,974\end{array}$} & \multirow{2}{*}{$(\$ / y r)$} & & \\
\hline \multirow[t]{3}{*}{ Winter } & Cogen Rate & & & & & & \\
\hline & Non-cogen Rate & 0 & & so & & & \\
\hline & sub-total & 64,651 & & $\$ 19,974$ & & & \\
\hline \multirow[t]{3}{*}{ Summer } & Cogen Rate & 240,388 & & $\$ 73,018$ & & & \\
\hline & Non-cogen Rato & 0 & & so & & & \\
\hline & sub-total & 240,388 & & $\$ 73,018$ & & & \\
\hline \multicolumn{2}{|l|}{ Total } & 305,039 & & $\$ 02,992$ & & & \\
\hline \multicolumn{2}{|c|}{ Electricity Generated: } & Enorgy & (kWis/yr) & Domand & (km) & & \\
\hline \multirow[t]{3}{*}{ Summor } & On-Poak & $1,758,744$ & & 2,440 & & & \\
\hline & Somi-Peak & 0 & & 0 & & & \\
\hline & Oft-Peak & 0 & & & & & \\
\hline \multirow[t]{3}{*}{ Winter } & On-Poak & $1,058,308$ & & 2,440 & & & \\
\hline & Somi-Poak & 0 & & 0 & & & \\
\hline & Off-Poak & 0 & & & & & \\
\hline \multicolumn{2}{|c|}{ Not Electricity Gonerated: } & Enorgy & $(k W n / y r)$ & Demand & $(\mathrm{kW})$ & Value & $(\$ / y r)$ \\
\hline \multirow[t]{4}{*}{ Summer } & On-Poak & $1,734,785$ & & 2,410 & & $\$ 280,773$ & \\
\hline & Semi-Poak & 0 & & 0 & & so & \\
\hline & Off-Poak & 0 & & & & 50 & \\
\hline & sub-total & $1,734,785$ & & & & $\$ 280,773$ & \\
\hline \multirow[t]{4}{*}{ Winter } & On-i'eak & $1,045,079$ & & 2,410 & & $\$ 101,092$ & \\
\hline & Somi-Poak & 0 & & 0 & & so & \\
\hline & Otf-Poak & 0 & & & & so & \\
\hline & sub-total & $1,045,079$ & & & & $\$ 101,092$ & \\
\hline \multicolumn{2}{|l|}{ Total } & $2,779,864$ & & & & $\$ 381,865$ & \\
\hline \multirow{2}{*}{\multicolumn{2}{|c|}{ Thermal Energy Recoverable: }} & Summer & & Winter & & Total & \\
\hline & & 70,004 & therms/yr & 42,226 & therms/yr & 112,321 & therms/yr \\
\hline \multicolumn{2}{|c|}{ Required Thermal Energy: } & Summor & (therms/yr) & Winter & (thorms/yr) & Total & (therms/yr) \\
\hline & Cooling & 178,330 & & 234,460 & & 410,790 & \\
\hline & Heating & 0 & & 0 & & 0 & \\
\hline & Ro-Hoat & 0 & & 0 & & 0 & \\
\hline & DHW & 4,183 & & 5,797 & & 9,980 & \\
\hline & sub-total & 180,513 & & 240,257 & & 420,770 & \\
\hline
\end{tabular}


Thermal Enorgy Recoverable \& Usoablo:

\begin{tabular}{|c|c|c|c|c|c|}
\hline & Enorgy & (therms/yr) & Stoam & (Mibs/yr) & Value \\
\hline Summer & 35,304 & & 4,013 & & $\$ 7,871$ \\
\hline Winter & 20,481 & & 2,322 & & $\$ 3,695$ \\
\hline Total & 55,875 & & 6,335 & & $\$ 11,568$ \\
\hline
\end{tabular}

Summary of Calculations:

Natural Ges Fuel Cost

$(\$ 92,992) / \mathrm{yr}$

Eloctrical Savings

$\$ 381,865 / Y T$

SDG\&E Back-up Cost

$(\$ 28,987) / y r$

Thermal Savings

$\$ 1 ., 566 / y r$

Not Energy Savings

$271,453 / y r$

Averago SDG\&E/FERC Efficiency $\quad \mathbf{4 4 . 7 4 \%}$

42.5\% or greater required for cogen gas rate

Dose qualify for cogen gas rate. 
TABLE G.10. Energy Analysis for Scenario 10

Gas Turbine Engine Data:

Number of Engines

Gonerator Capacity

Contracted Domand

Hoat Rate (HHM)

Thermal Recovery

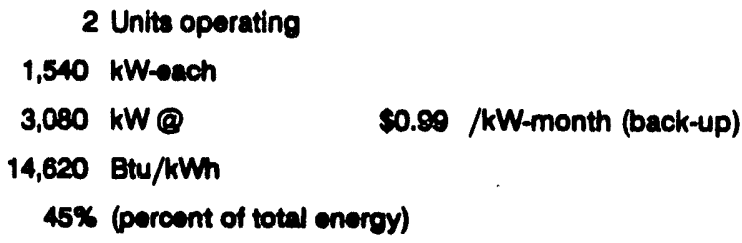

\begin{tabular}{|c|c|c|c|c|c|c|c|}
\hline \multicolumn{2}{|c|}{ Available Operating Hours } & 8,760 & $h / y r$ & & & & \\
\hline \multicolumn{2}{|c|}{ Scheduled Downtime } & 260 & $h / y r$ & & & & \\
\hline \multicolumn{2}{|c|}{ Not Operating Hours } & 8,500 & $h / y$ & & & & \\
\hline \multicolumn{2}{|c|}{ Not Utillzation of Hours } & $97 \%$ & & & & & \\
\hline \multicolumn{2}{|c|}{ Load Utllization Factor } & $100 \%$ & (avera & load factor & when in opers & & \\
\hline \multicolumn{2}{|c|}{ Powerhouse Land } & $1.25 \%$ & (porce & ueed in pow & verhouse) & & \\
\hline \multicolumn{2}{|c|}{ Electric Rate Schedule: } & Hours/Yr & & Enorgy & $(\$ / k W h)$ & Domand & $(s / \mathrm{kW})$ \\
\hline \multirow[t]{4}{*}{ Summer } & On-Poak & 742 & & $\$ 0.06886$ & & $\$ 13.39$ & \\
\hline & Somi-Poak & 954 & & $\$ 0.04633$ & & $\$ 1.24$ & \\
\hline & Off-Peak & 1,976 & & $\$ 0.03360$ & & & \\
\hline & sub-total & 3,672 & & & & & \\
\hline \multirow[t]{5}{*}{ Winter } & On-Poak & 447 & & $\$ 0.06171$ & & $\$ 2.17$ & \\
\hline & Somi-Poak & 1,937 & & $\$ 0.03864$ & & $\$ 1.24$ & \\
\hline & Off-Paak & 2,704 & & $\$ 0.03186$ & & & \\
\hline & sub-total & 5,088 & & & & & \\
\hline & Total & 8,760 & & & & & \\
\hline \multicolumn{2}{|c|}{ Natural Gas Rato Schedule: } & Hours/Yr & & Enorgy & (S/therm) & & \\
\hline \multirow[t]{3}{*}{ Winter } & Cogen Rate & 2,904 & & $\$ 0.30885$ & & 0.107 & therm/kWh \\
\hline & Non-cogen Rate & 2,904 & & $\$ 0.36622$ & & 1,032 & Btu/cuft HHV \\
\hline & & & & & & 928.8 & Btu/cuft LHV \\
\hline \multirow[t]{2}{*}{ Summer } & Cogen Rate & 5,856 & & $\$ 0.30375$ & & & \\
\hline & Non-cogen Rate & 5,858 & & $\$ 0,35185$ & & & \\
\hline \multicolumn{2}{|c|}{ Steam Rate Schedulo: } & Hours/ $/ \mathrm{r}$ & & Enorgy & (S/thorm) & & \\
\hline Summer & Marginal Rate & 3,672 & & $\$ 0.222$ & & & \\
\hline \multirow[t]{2}{*}{ Winter } & Marginal Rate & 5,088 & & $\$ 0.180$ & & & \\
\hline & & 8,760 & & & & & \\
\hline
\end{tabular}

Operating Sohedule:

On-Pank

Somi-Poak

Off-Poak

Natural Gas Rato Schedule:

$\begin{array}{cc}\text { Summor } & \text { Winter } \\ Y & Y \\ Y & Y \\ Y & Y\end{array}$

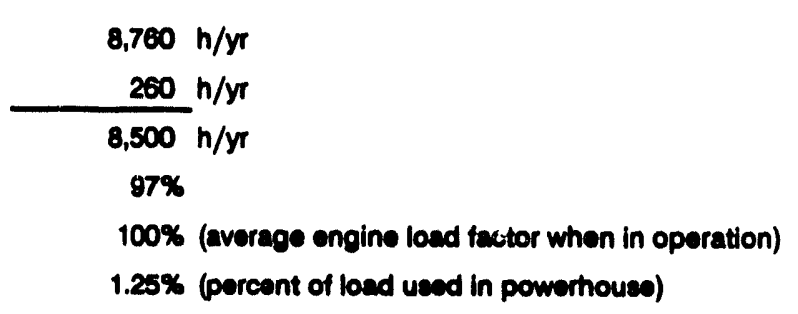


TABLE G.10. Energy Analysis for Scenario 10 (contd)

\begin{tabular}{|c|c|c|c|c|c|c|c|}
\hline \multicolumn{2}{|c|}{ Natural Gas Consumed: } & \multirow{2}{*}{$\begin{array}{r}\text { Energy } \\
0\end{array}$} & \multirow[t]{2}{*}{ (therms/yr) } & \multirow{2}{*}{$\begin{array}{l}\text { Value } \\
\text { so }\end{array}$} & \multirow[t]{2}{*}{$(\$ / y r)$} & & \\
\hline Wnter & Cogen Rate & & & & & & \\
\hline & Non-cogen Rate & $1,309,451$ & & $\$ 479,547$ & & & \\
\hline & sub-total & $1,300,451$ & & $\$ 479,547$ & & & \\
\hline \multirow[t]{3}{*}{ Summor } & Cogen Rate & 0 & & so & & & \\
\hline & Non-cogen Rate & $2,640,546$ & & $\$ 929,076$ & & & \\
\hline & sub-total & $2,640,546$ & & $\$ 929,076$ & & & \\
\hline \multicolumn{2}{|l|}{ Total } & $3,949,997$ & & $\$ 1,408,623$ & & & \\
\hline \multicolumn{2}{|c|}{ Eectricity Genorated: } & Enorgy & $(\mathrm{kWn} / \mathrm{yr})$ & Domand & $(\mathrm{kW})$ & & \\
\hline \multirow[t]{3}{*}{ Summer } & On-Poak & $2,217,530$ & & 3,080 & & & \\
\hline & Somi-Poak & $2,851,110$ & & 3,080 & & & \\
\hline & Off-Poak & $5,905,443$ & & & & & \\
\hline \multirow[t]{3}{*}{ Winter } & On-Peak & $1,335,897$ & & 3,080 & & & \\
\hline & Semi-Peak & $5,788,888$ & & 3,080 & & & \\
\hline & Off-Peak & $8,081,132$ & & & & & \\
\hline \multicolumn{2}{|c|}{ Not Eectricity Gonerated: } & Enorgy & $(k W n / y r)$ & Demand & $(\mathrm{kW})$ & Value & $(S / y r)$ \\
\hline \multirow[t]{4}{*}{ Summer } & On-Poak & $2,189,811$ & & 3,042 & & $\$ 354,419$ & \\
\hline & Somi-Poak & $2,815,471$ & & 3,042 & & $\$ 146,483$ & \\
\hline & OH-Peak & $5,831,625$ & & & & $\$ 196,467$ & \\
\hline & sub-total & $10,836,906$ & & . & & $\$ 697,369$ & \\
\hline \multirow[t]{4}{*}{ Winter } & On-Poak & $1,319,199$ & & 3,042 & & $\$ 127,608$ & \\
\hline & Somi-Poak & $5,716,527$ & & 3,042 & & $\$ 247,287$ & \\
\hline & Ott-Poak & $7,980,118$ & & & & $\$ 254,247$ & \\
\hline & sub-total & $15,015,844$ & & & & $\$ 629,142$ & \\
\hline \multicolumn{2}{|l|}{ Total } & $25,852,750$ & & & & $\$ 1,326,510$ & \\
\hline \multirow{2}{*}{\multicolumn{2}{|c|}{ Thermal Energy Recoverable: }} & Summer & & Wintor & & Total & \\
\hline & & 721,985 & therms/yr & $1,000,397$ & therms/yr & $1,722,382$ & therms/yr \\
\hline \multicolumn{2}{|c|}{ Required Thermal Energy: } & Summer & (therms/yr) & Winter & (therms/yr) & Total & (therms/yr) \\
\hline & Cooling & 178,330 & & 234,460 & & 410,790 & \\
\hline & Hoating & 0 & & 0 & & 0 & \\
\hline & Ra-Heat & 0 & & 0 & & 0 & \\
\hline & DHW & 4,183 & & 5,797 & & 9,980 & \\
\hline & sub-total & 180,513 & & 240,257 & & 420,770 & \\
\hline
\end{tabular}


TABLE G.10. Energy Analysis for Scenario 10 (contd)

Thermal Energy Rocoverable \& Useable:

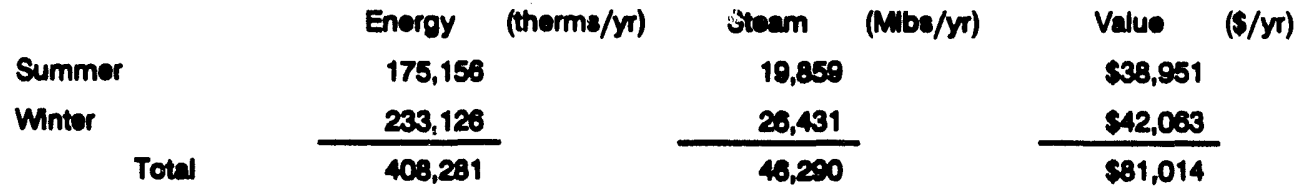

Summary of Calculations:

Natural Gas Fuel Cost

Electrical Savinge

SDG\&E Back-up Cost

Thermal Savings

Not Enorgy Savings

Avorage SDG\&E/FEAC Efficiency
$(\$ 1,408,623) / y r$

$\$ 1,326,510 / y r$

$(\$ 36,590) / y r$

$\$ 81,014 / y T$

$(37,689) / y r$

$30.56 \%$

42.5\% or greater required for cogen gas rate

Dose not quality for cogen gas rate. 
TABLE G.11. Energy Analysis for Scenario 11

Gas Turbino Engino Data:

Number of Engines

Gonerator Capacty

Contrected Domand

Hoat Rate (HHM)

Thermal Pcoovery
2 Units operating

$1,540 \mathrm{~kW}$-aech

$3,000 \mathrm{~kW} @ \quad 50.90 / \mathrm{kW}$-month (back-up)

$14,620 \mathrm{Btu} / \mathrm{kWh}$

45\% (porcont of total energy)

Operating Schedulo:

On-Poak

Somi-Poak

Off-Poak

Available Oporating Hours

Schoduled Downtime

Not Operating Hours

Not Utilization of Hours

Load Utilization Factor

Poworhouse Load

$\begin{array}{cc}\text { Summor } & \text { Wintor } \\ Y & Y \\ Y & Y \\ \text { N } & \text { N }\end{array}$

Eectric Rato Schodulo:

Summer On-Poak

Somi-Poak

Otf-Poak

sub-total

Wintor

On-Poak

Somi-Poak

Otf-Poak

sub-total

Total

Natural Gas Rato Schedulo:

Wintor Cogon Rate

Non-cogon Rato

Summer Cogon Rato

Non-cogen Rato

Stoam Rato Schodulo:

Summor Marginal Rate

Wintor

Marginal Rato

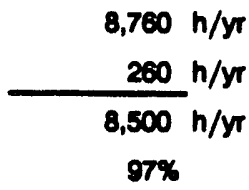

100\% (average engine load factor when in operation)

$1.25 \%$ (poreent of load used in powerhouse)

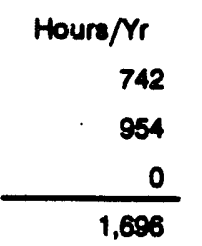

Enorgy $(\$ / \mathrm{kWh})$

$\$ 0.06886$

$\$ 0.04533$

$\$ 0.03360$

$\$ 0.06171$

$\$ 2.17$

50.03864

$\$ 1.24$

$\$ 0.03188$

$\begin{array}{r}0 \\ \hline 2,384 \\ \hline 4,080\end{array}$

Hours/Mr

1,344

1,344

s0.30895

(\$/thorm)

$\$ 0.36622$

0.107 therm $/ \mathrm{kWh}$

1,032 Btu/cutt HHV

$928.8 \mathrm{Btu} /$ cuft LHV

$\$ 0.30375$

$\$ 0.35186$

2,736

Energy (\$/therm)

$\$ 0.222$

$\$ 0.180$

.

G.31 
TABLE G.11. Energy Analysis for Scenario 11 (contd)

\begin{tabular}{|c|c|c|c|c|c|c|c|}
\hline \multicolumn{2}{|c|}{ Natural Gas Consumed: } & \multirow{2}{*}{$\begin{array}{l}\text { Energy } \\
0\end{array}$} & \multirow[t]{2}{*}{ (therms/yr) } & \multirow{2}{*}{$\begin{array}{l}\text { Value } \\
\text { so }\end{array}$} & \multirow[t]{2}{*}{$(\$ / y r)$} & & \\
\hline \multirow[t]{3}{*}{ Winter } & Cogen Rate & & & & & & \\
\hline & Non-cogen Rate & 606,027 & & $\$ 221,980$ & & & \\
\hline & sub-total & 608,027 & & 5221,230 & & & \\
\hline \multirow[t]{3}{*}{ Summor } & Cogen Pate & 0 & & so & & & \\
\hline & Non-cogen Rate & $1,233,698$ & & $\$ 434,076$ & & & \\
\hline & sub-total & $1,233,698$ & & S434,078 & & & \\
\hline \multicolumn{2}{|l|}{ Total } & $1,839,724$ & & $\$ 656,016$ & & & \\
\hline & & & & $\cdot$ & & & \\
\hline \multicolumn{2}{|c|}{ Eectricity Gonerated: } & Energy & $(\mathrm{kWh} / \mathrm{yr})$ & Demand & $(\mathrm{kW})$ & & \\
\hline \multirow[t]{3}{*}{ Summer } & On-Poak & $2,217,530$ & & 3,080 & & & \\
\hline & Somi-Poak & $2,851,110$ & & 3,080 & & & \\
\hline & Otf-Poak & 0 & & & & & \\
\hline \multirow[t]{3}{*}{ Wintor } & On-Poak & $1,335,897$ & & 3,080 & & & \\
\hline & Somi-Poak & $5,788,888$ & & 3,080 & & & \\
\hline & Orf-Poak & 0 & & & & & \\
\hline \multicolumn{2}{|c|}{ Not Eectrictiy Gonerated: } & Energy & $(k W n / y r)$ & Domand & $(k W)$ & Valuo & $(\$ / y r)$ \\
\hline \multirow[t]{4}{*}{ Summor } & On-Poak & $2,189,811$ & & 3,042 & & $\$ 354,419$ & $/ y r$ \\
\hline & Somi-Poak & $2,815,471$ & & 3,042 & & $\$ 146,483$ & $/ y r$ \\
\hline & Off-Poak & 0 & & & & so & $/ y r$ \\
\hline & sub-total & $5,005,281$ & & & & $\$ 500,901$ & \\
\hline \multirow[t]{3}{*}{ Winter } & On-Poak & $1,319,189$ & & 3,042 & & $\$ 127,608$ & $/ y r$ \\
\hline & Somi-Poak & $5,716,527$ & & 3,042 & & $\$ 247,287$ & $/ y r$ \\
\hline & Off-Poak & 0 & & & & so & $/ y r$ \\
\hline . & eub-total & $7,035,720$ & & - & & $\$ 374,896$ & \\
\hline \multicolumn{2}{|l|}{ Total } & $12,041,007$ & & & & $\$ 875,796$ & \\
\hline \multirow{2}{*}{\multicolumn{2}{|c|}{ Thermal Enorgy Rocoverable: }} & Summer & & Winter & & Total & \\
\hline & & 333,468 & therms/yr & 468,740 & therms/yr & 802,205 & therms/yr \\
\hline \multicolumn{2}{|c|}{ Required Thermal Eneroy: } & Summer & (therms/yr) & Winter & (therms/yr) & Total & (therms/yr) \\
\hline & Cooling & 176,330 & & 234,460 & & 410,790 & \\
\hline & Heating & 0 & & 0 & & 0 & \\
\hline & Ro-Hoat & 0 & & 0 & & 0 & \\
\hline & DHW & 4,183 & & 5,797 & & 9,980 & \\
\hline & sub-total & 180,513 & & 240,257 & & 420,770 & \\
\hline
\end{tabular}


TABLE G.11. Energy Analysis for Scenario 11 (contd)

Thermal Enorgy Recoverable \& Usoable:

\begin{tabular}{|c|c|c|c|c|c|}
\hline & Energy & (therms/yr) & Steam & (Mlbs/yr) & Value \\
\hline Summer & 80,900 & & 9,172 & & $\$ 17,990$ \\
\hline Wintor & 109,232 & & 12,385 & & $\$ 19,709$ \\
\hline Total & 190,132 & & 21,557 & & $\$ 37,690$ \\
\hline
\end{tabular}

Summary of Calculations:

Natural Gas Fuel Cost

Electrical Sayings

SDG\&E Back-up Cost

Thermal Savings

Not Energy Savinge

Average SDG8E/FERC Efficioncy

$$
\begin{aligned}
& (\$ 656,016) / y r \\
& \$ 875,796 / y r \\
& (\$ 36,590) / y r \\
& \$ 37,699 / y r \\
& 220,889 / y r
\end{aligned}
$$

$30.56 \%$
42.5\% or greater required for cogen gas rate Does not quality for cogen gas rate. 
TABLE G.12. Energy Analysis for Scenario 12

Gas Turbine Engine Data:

$$
\begin{aligned}
& \text { Number of Engines } \\
& \text { Gonerator Capacity } \\
& \text { Contracted Domand } \\
& \text { Hoat Rate (HHM) } \\
& \text { Thermal Recovery }
\end{aligned}
$$

Oporating Schedule:

On-Poak

Soml-Poak

OH-Poak

Avalable Operating Hours

Scheduled Downtime

Not Oporating Hours

Not Utilization of Hours

Load Utilization Factor

Powerhouse Load

Electric Rato Schodulo:
Summer On-Poak
Semi-Poak
Off-Peak
sub-total
Winter

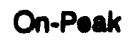
Somi-Peak
Off-Poak

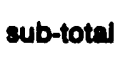
Total

Natural Gas Rate Schedule:
Winter Cogen Rate
Non-cogen Rate
Summer Cogen Rate
Non-cogen Rate

Steam Rate Schedule:

Summer Marginal Rate
Winter Marginal Rate

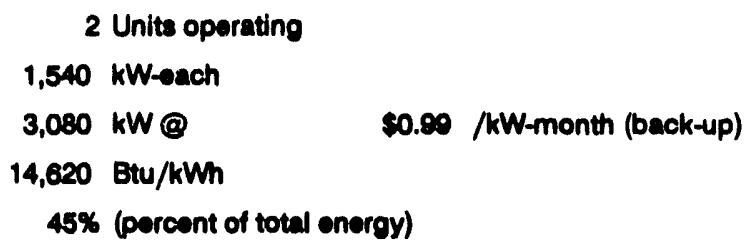

$\begin{array}{cc}\text { Summer } & \text { Wintor } \\ \mathbf{Y} & \mathbf{Y} \\ N & \text { N } \\ N & N\end{array}$

Houre/Yr

742

0

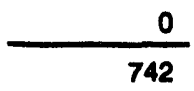

742

447

0

0

447

1,189

Hours/ $\mathrm{Yr}$

252

252

937

937

742

447

1,189
Energy ( $\$ / \mathrm{kWh})$

$\$ 0.06886$

$\$ 0.04533$

$\$ 0.03369$

S0.08171

s0.03884

$\$ 0.03188$

Enorgy (\$/thorm)

$\$ 0.30895$

$\$ 0.36822$

S0.30375

$\$ 0.35185$

$\$ 0.222$

$\$ 0.180$
$\$ 2.17$

Domand $(\$ / \mathrm{kW})$

$\$ 13.39$

$\$ 1.24$

$\$ 1.24$
0.107 therm/kWh

1,032 Btu/cuft HHV

928.8 Biu/cutt LHV 
TABLE G.12. Energy Analysis for Scenario 12 (contd)

\begin{tabular}{|c|c|c|c|c|c|c|c|}
\hline \multicolumn{2}{|c|}{ Natural Gas Consumed: } & \multirow{2}{*}{$\begin{array}{l}\text { Energy } \\
0\end{array}$} & \multirow{2}{*}{ (therms/yr) } & \multirow{2}{*}{$\begin{array}{l}\text { Value } \\
\qquad \leqslant 0\end{array}$} & \multirow[t]{2}{*}{$(S / y r)$} & & \\
\hline Wintor & Cogen Rate & & & & & & \\
\hline & Non-cogen Rato & 113,630 & & $\$ 41,614$ & & & \\
\hline & sub-total & 113,630 & & $\$ 41,614$ & & & \\
\hline \multirow[t]{3}{*}{ Summer } & Cogen Rate & 0 & & so & & & \\
\hline & Non-cogen Rate & 422,505 & & $\$ 148,650$ & & & \\
\hline & sub-total & 422,505 & & $\$ 148,659$ & & & \\
\hline \multicolumn{2}{|l|}{ Total } & 536,135 & & $\$ 190,272$ & & & \\
\hline \multicolumn{2}{|c|}{ Electricity Gonerated: } & Energy & $(\mathrm{kWn} / \mathrm{yr})$ & Domand & (kW) & & \\
\hline \multirow[t]{4}{*}{ Summer } & On-Poak & $2,217,530$ & & 3,080 & & & \\
\hline & Somi-Poak & 0 & & 0 & & & \\
\hline & Ott-Peak & 0 & & & & & \\
\hline & & & & $\cdot$ & & & \\
\hline \multirow[t]{3}{*}{ Winter } & On-Poak & $1,335,897$ & & 3,080 & & & \\
\hline & Somi-Poak & 0 & & 0 & & & \\
\hline & Off-Peak & 0 & & & & & \\
\hline \multicolumn{2}{|c|}{ Not Electricity Gonorated: } & Enorgy & (kWh/yr) & Domand & $(\mathbf{k W})$ & Value & $(\$ / y r)$ \\
\hline \multirow[t]{4}{*}{ Summer } & On-Poak & $2,189,811$ & & 3,042 & & $\$ 354,419$ & \\
\hline & Semi-Peak & 0 & & 0 & & so & \\
\hline & Off-Poak & 0 & & & & $\$ 0$ & \\
\hline & sub-total & $2,189,811$ & & & & $\$ 354,419$ & \\
\hline \multirow[t]{4}{*}{ Winter } & On-Poak & $1,319,199$ & & 3,042 & & $\$ 127,608$ & \\
\hline & Somi-Poak & 0 & & 0 & & so & \\
\hline & Off-Poak & 0 & & & & so & \\
\hline & sub-total & $1,319,199$ & & & & $\$ 127,608$ & \\
\hline \multicolumn{2}{|l|}{ Total } & $3,509,009$ & & & & $\$ 482,027$ & \\
\hline \multirow{2}{*}{\multicolumn{2}{|c|}{ Thermal Energy Rocoverable: }} & Summor & & Wintor & & Total & \\
\hline & & 145,891 & therms/yr & 87,889 & therms/yr & 233,780 & therms/yr \\
\hline \multicolumn{2}{|c|}{ Required Thermal Energy: } & Summer & (therms/yr) & Winter & (therms/yr) & Total & (therms/yr) \\
\hline & Cooling & 176,330 & & 234,460 & & 410,790 & \\
\hline & Hoating & 0 & & 0 & & 0 & \\
\hline & Ro-Hoat & 0 & & 0 & & 0 & \\
\hline & DHW & 4,183 & & 5,797 & & 9,980 & \\
\hline & sub-total & 180,513 & & 240,257 & & 420,770 & \\
\hline
\end{tabular}


TABLE G.12. Energy Analysis for Scenario 12 (contd)

Thermal Energy Rocoverable \& Usoable:

\begin{tabular}{|c|c|c|c|c|c|}
\hline & Energy & (therms/yr) & Stoam & (Mlbs/yr) & Valuo \\
\hline Summer & 35,394 & & 4,013 & & $\$ 7,871$ \\
\hline Wintor & 20,481 & & 2,322 & & $\$ 3,695$ \\
\hline Total & 55,875 & & 6,335 & & $\$ 11,568$ \\
\hline
\end{tabular}

Summary of Calculations:

Natural Gas Fual Cost

Electrical Savings

SDG\&E Back-up Cost

Thormal Savings

Not Enorgy Savings

Averago SDG\&E/FERC Efficioncy

$$
\begin{gathered}
(\$ 190,272) / y r \\
\$ 482,027 / y r \\
(\$ 36,590) / y r \\
\$ 11,566 / y r \\
266,731 / y r
\end{gathered}
$$

$30.61 \%$
42.5\% or greater required for cogen gas rate Does not quality for cogen gas rate. 
Appendix $\mathbf{H}$

Permit to Operate 
$\because$

\section{PL.RMIT TO OPERACE}

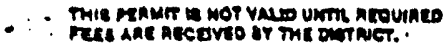

JUN 5 I EXPARES

JAMUARY 1. 1992

THE ROLLOWING IS MEREBY GRANTED A PERMIT TO ODEAATE THE ARTICLE. MACHINE, TOUIPMENT OA CONTMIYANCE DESCAIGE

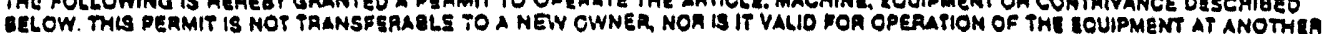

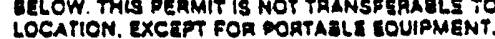

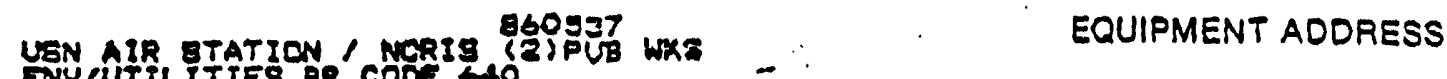

ENUTUILITIES BR CODE 640
BNY DIESO

BN DIENo

CA 92135

EQUIPMENT DESCRIPTION

RENEWAL FEE \$\$.254.00

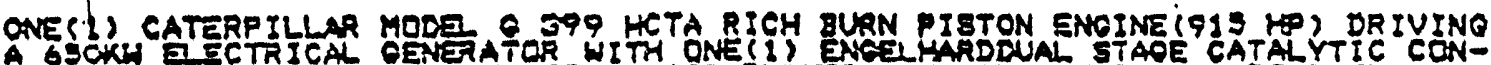

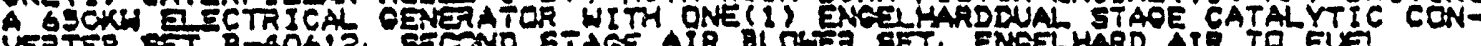

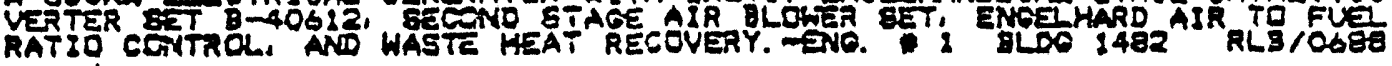

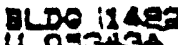

360537 0901L 34AO1 TEF01 92601

860537

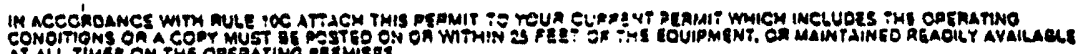

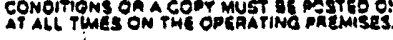

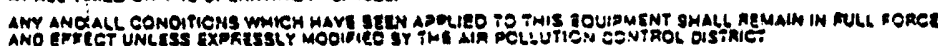

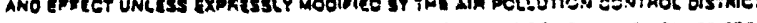

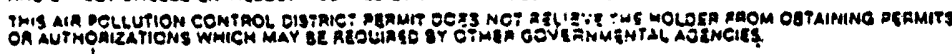

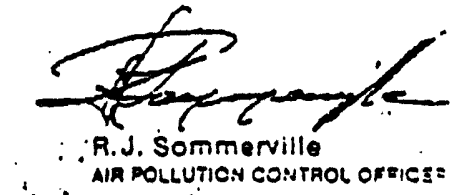

1. ACCESS FACILITIES AND UTILITIES FCR SOURCE TESTINC AS RESISIRED BY THE AT POLLUTIDN CONTRCL DFFICEF SHALL BE PRDVIDEO WHEN SUEH TESTING IS PERFORITED BY THE DISTRICITHESEOF, IUCLUDINO THE PEFMIT CONOITIONG, SHALL BE

2. ATTACHED TO OR ACCOMPANY THE EQUI PMENT AT ALL TIMES.

3. AT GXIDES OF NITROGEN (NDX) ETISSIONS FRDM THE ENSINE SHALL NOT EXCEED ZIS PARTS PER MILLION BY VOLLME ONT DN A ERY BASIS

AT THREE (3) PREENT QXIGEN QN FA THE ENETNE SHALL NOT EXCESD 350 PAPTS PER

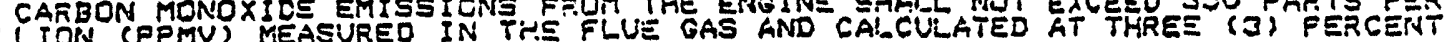
OKIGSN ON A DRY BASIS.

5. THE ENGELLHAPD AIR TO FUEL RATIO CCHTROLLER SHAIL BE IPIEPECTED EVERY 2OUO

HOURS FOR PROPER OPERATIQN. THE QRYGEN SENSCRS EHALL BE REPLACED

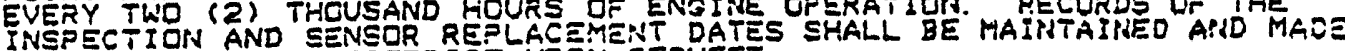
AVAILATLE TO THE DISTRICT UFEN REQUEST

6. AVAILASLE TO THE OLSIRITTER SET SHALL BE OPERATED AT A LOAO RFTING CF GOO KW

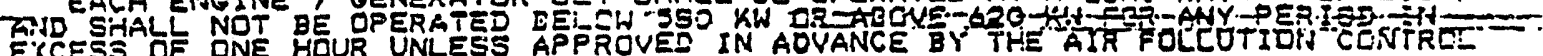
DISTRICT.

7. THE GYPASS VALVE ON EACH BLCWER THAT SUPPLIES ADDITIONAL AIR TO THE SECOND STAGE CATALYTIC CONVERTER SHALL BE MAINTAIPED IN THE OPEN POSTION ESTABLISHED FOR THE INITIAL COMPLIANCE TEST. TH LCEKING DE SHALL $3 E$ A

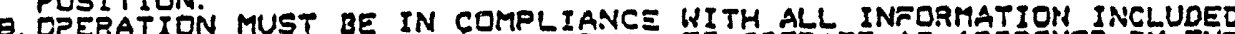

9. OPERATIDN MUST BE IN THES PERMIT TO DPERATE AS APPREVED BY THE DISTRICT AND THE FERFORMANCE CONDITIONS LISTEO ABUVE.

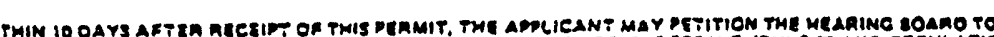

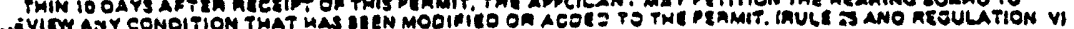

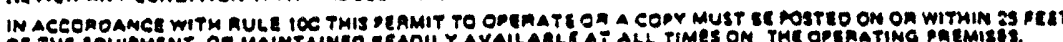

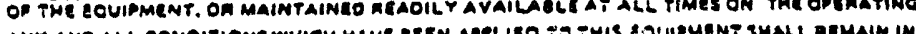

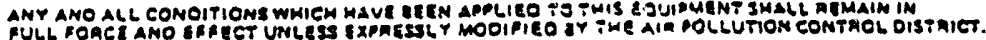

THIS AIA POLLUTION CONTAOL OISTAICT PEAMIT ODES NOT AELSEVE THE NOLDLA AAOM OATAIMIMO

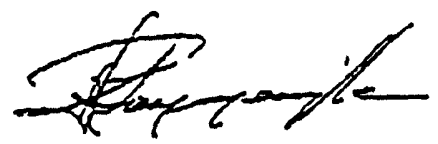

R.J. Sommerville

AIA POLLUTION CONTAOL OEFICF=

H.1 


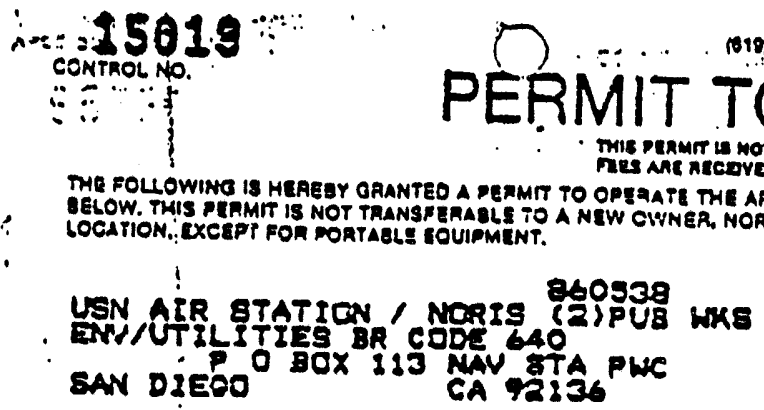

EQUIPMENT DESCRIPTION

\section{ONE(1) CATEPPI RENEWALFEE \$\$. 254.00 6OOKW GATERP ILLAR MODE OS99 RICH BURN PIBTON ENOINE (915 HP) DRIVINO A

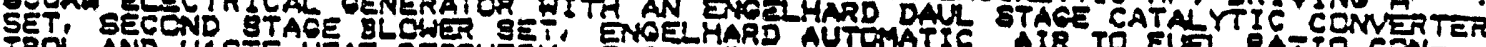 TLOL AND WASTE HEAT RECOVERY. -ENG. ? \\ U 05343A 860538 0902L 34401 92501 92001 APP. 860939}

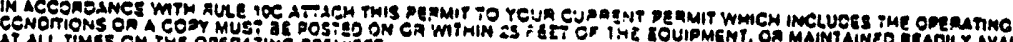

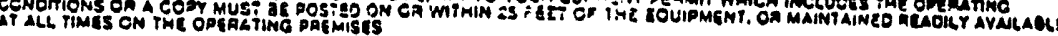

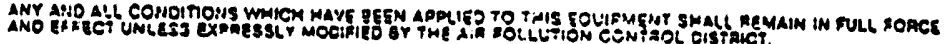

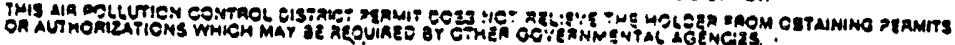

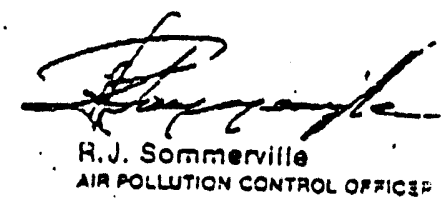
ACCESS FACILITIES AND UTI ITIES FUE SOURC TESTINO AS REQUIREO EY THE AIPRPOLLUTIDN CONTREL CFF

ATTACHED TO OR' ACCOMPANY THEEOF INACLUDING THE PERMIT CONOITIONS, SHALL BE

3. OXIDES OF NITRDGEN (NOX) EM SEIONS FROM THT STOS.

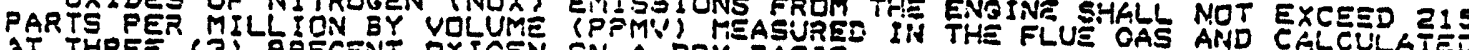
THRE (3) PRECENT OXIGEN OH A CRY BASIS.

CARBON MONOXIDE EMISS I GNS EECM THE ENGINE SHALL MOT EXCEED 350 PARTS PER

OKIGEN ON A DRY BASIS.

s.

HOURS FONGELHARD AIRTTO FUEL RATIO CONTROLLER SHAL BE IYYPECTED EVERY 2000

EVERY TWO (2) THOUSAND HOURS OTF ENGINEN OFENSORS SHALL RE REPLACEO AT LEAST

INSPECTION AND SENSOR REDLAC

GVAILATLE TO D SENSLR REPLACEMENT DATES SHALL BE MAINTAITEO AISD MADE

6.

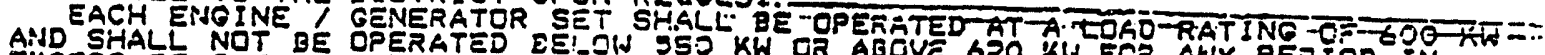

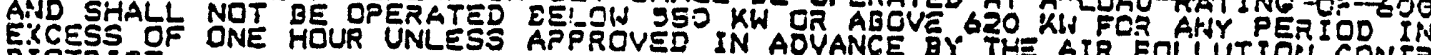

DISTR ICT. ONE HOUR UNLESS ATRROVED IN AOVANCE GY THE AIR FOLLUTIOR CONTROL

7.

SECONE SYPASS YALVE ON EACH J E'ONER THAT SUPPLIES ADDITIONAL AIR TO THE

POSTION ESTABLISTLD FOR THE INITIAL COMOE MAINTATHEO IN THE OPEN Ć CLESED

SHAL BE AFFIXED TO THE VALVE TO SEAL THE VALVE IN THE APPROPRIATE

8.

9. OPEFATION MUST BE IN COMPLIANCE WITH ALL INFRRMATIOR INCLUDED

AND THE PERFORMANCE COISDTIONS LISTED ABOEE APPROVED BY THE DISTRICT

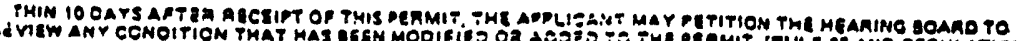

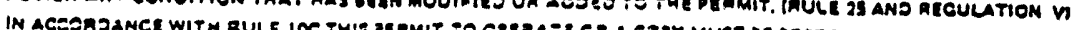

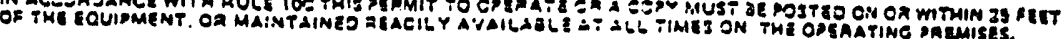

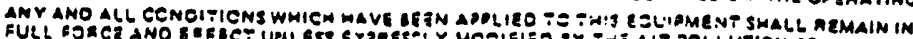

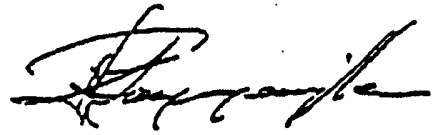

R.L. Sommerville 


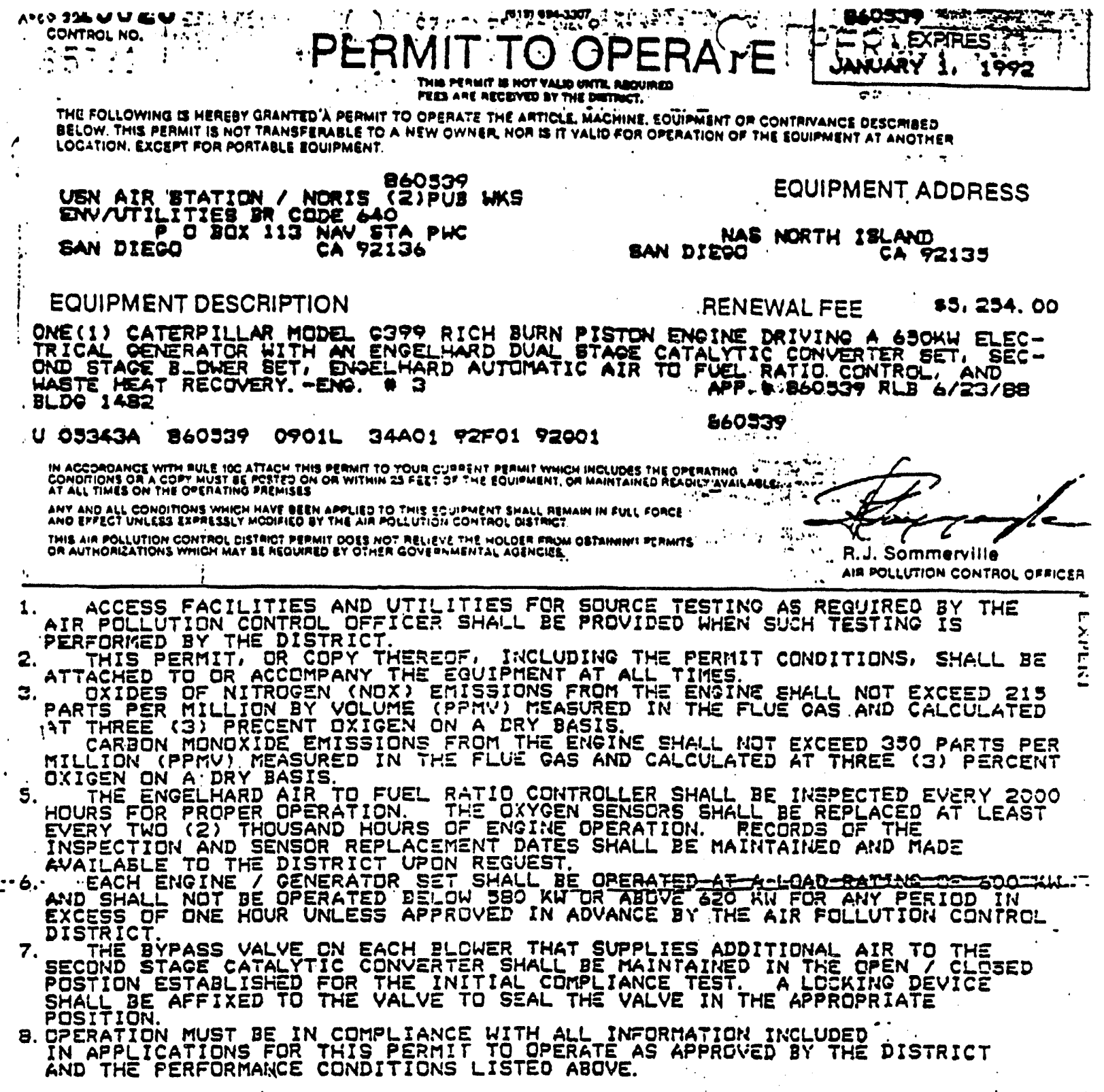

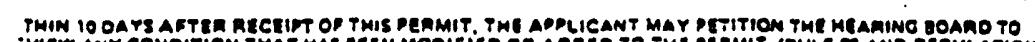

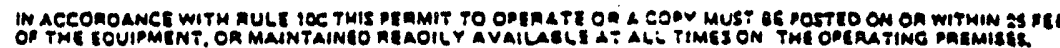

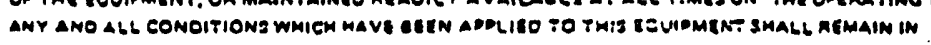

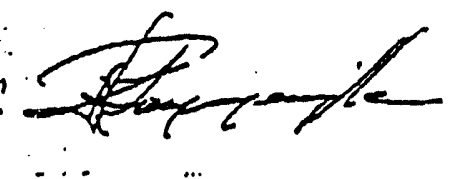

H.3 


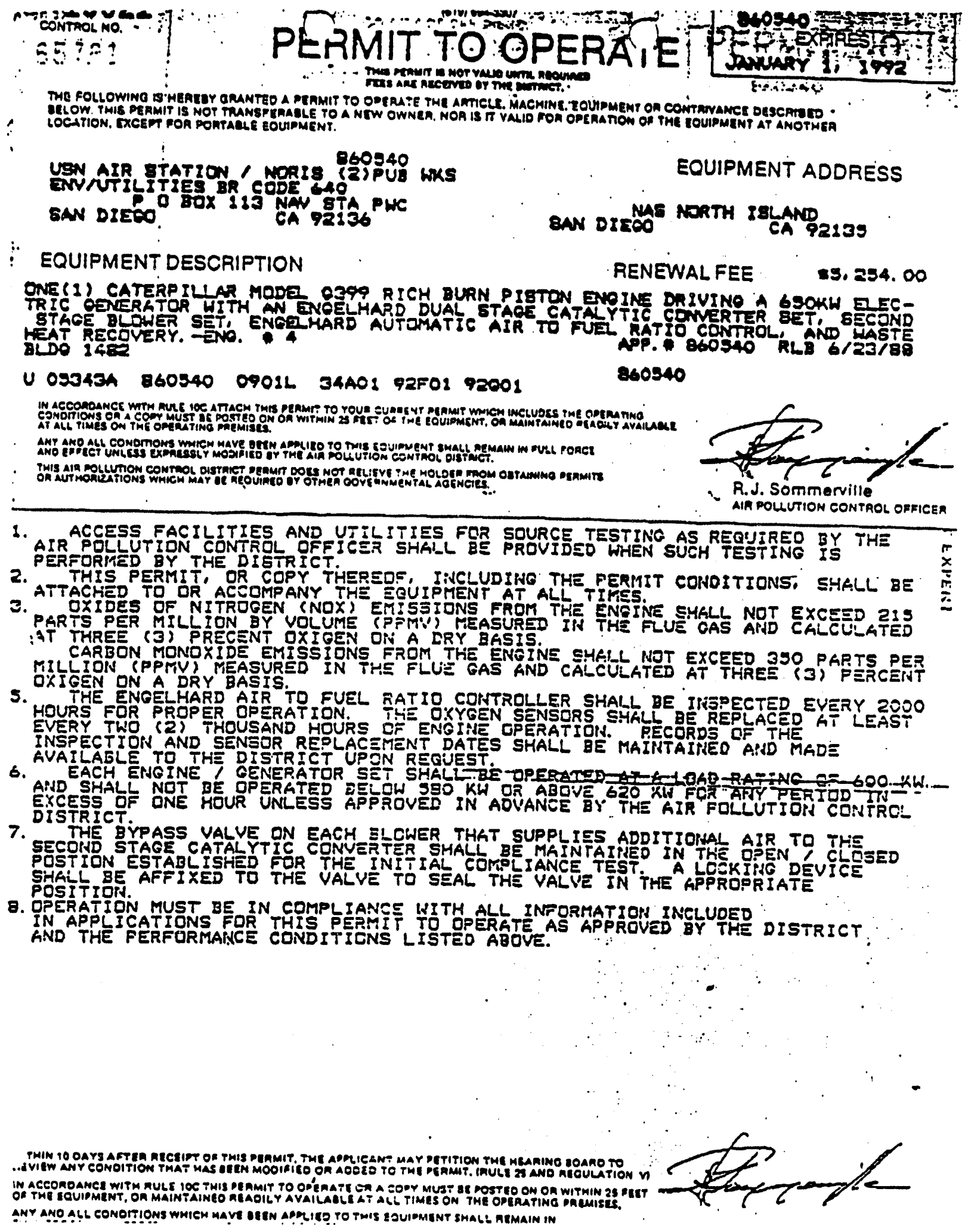

H.4 
Appendix I

Energy Technology Engineering Center Report 


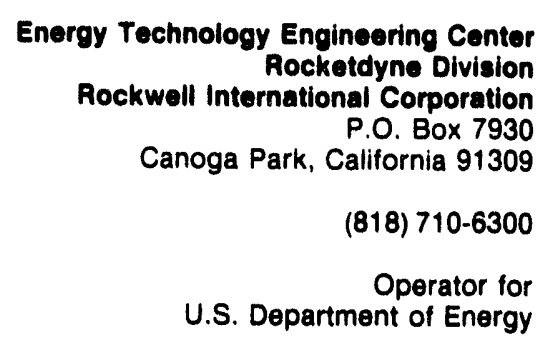

26 March 1993
In reply refer to 93ETEC-DRF 0536

Mr. Steven A. Parker

Senior Research Engineer

Battelle

Pacific Northwest Laboratories

Battelle Boulevard

P. O. Box 999

Richland, Washington 99352

Subject: Evaluation of MCTS NASNI Cogeneration Plant

Dear Mr. Parker:

The subject evaluation has been completed (enciosure). The Naval Computer \& Telecommunications Station (NCTS) at Naval Air Station North Island (NASNI), San Diego, CA was site-visited on 1-2 March 1993. Various persons from the Navy Public Works Center were interviewed, including the following:

Norman Groth, Cogeneration Department Head

Richard Imel, Foreman

John Thomas, Manager

I also interviewed Robert Winn, P. E. Executive Vice President, Pentech Services, Inc. All four cogen units in Building 1482 were inspected, the Unscheduled Repair Log Book, Job Orders, and Engine Maintenance Contract (with Pentech) were reviewed. The San Diego Gas \& Electric's various rate schedules were also obtained.

Telephone calls were also made and included the following:

1. Woodward Governor Co. Fort Collins, Colorado

2. Gerhardt's Inc. Ventura, California

3. Mechanical Equipment, Inc. Midland, Texas
4. Caterpillar, Inc. Peoria, Illinois

5. Hawthorne Power Systems San Diego, California

6. Pentech Services, Inc. San Diego, California 
Ref: 93ETEC-DRF 0536

26 March 1993

Page 2

The evaluation includes the past year's Unscheduled Repair Log Book and Job Orders information (Table 1). It also includes the various rate schedules of SDG\&E and the persons telephoned with addresses and phone numbers (Table 2).

If you have any questions, or if we can be of further assistance, please call me at (818) 586-5510.

Sincerely,

ROCKWELL INTERNATIONAL CORPORATION

Rocketdyne Division

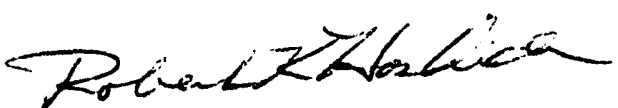

Robert K. Hoshide, CEM, CLEP

Project Manager, Energy Management

Energy Technology Engineering Center

D030-0038/bs

Enclosures as noted

cc w/o enclosures: R. LeChevalier, DOE, ETEC Site Mgr 
Table 1

UNSCHEDULED REPAIR LOG PENTEC SERVICES, INC.

\begin{tabular}{|c|c|c|}
\hline Date & Unit No. & Description \\
\hline $10 / 03 / 91$ & 2 & Brazed water line on water pump inlet. \\
\hline $10 / 04 / 91$ & 4 & Synchro Switch (overspeed switch) checked out \& parts ordered. \\
\hline $10 / 08 / 91$ & 3 & Synchro start overspeed switch installed. \\
\hline $11 / 26 / 91$ & 2 & Replaced La Marche battery charger. \\
\hline $02 / 21 / 92$ & 4 & Swapped load controller from Unit No. 2. \\
\hline $02 / 22 / 92$ & 3 & $\begin{array}{l}\text { AFRC would not control flowrate nor read proper milivolts from } \mathrm{O}_{2} \text { sensor } \\
\text { used No. } 2 \text { AFRC. Hard time getting controller as part was discontinued. }\end{array}$ \\
\hline $03 / 19 / 92$ & 4 & Helped checkout load controller (2301). \\
\hline $04 / 01 / 92$ & 4 & $\begin{array}{l}\text { Engine would not operate at proper speed. Found short in wiring, governor } \\
\text { O.K. Kato Generator: smoke \& coming apart internally. }\end{array}$ \\
\hline $04 / 10 / 92$ & 3 & Engine would not start, used No. 4 batteries then replaced No. 4 batteries. \\
\hline $05 / 20 / 92$ & 1 & Broken exhaust valve in No. 14 cylinder. Rebuilt engine. \\
\hline $06 / 23 / 92$ & 2 & Water pump leaking. \\
\hline $08 / 20 / 92$ & 3 & $\begin{array}{l}\text { Power supply in AFRC burned-up. Used No. } 4 \text { \& repaired control board \& } \\
\text { installed in No. } 4 \text {. }\end{array}$ \\
\hline $08 / 20 / 92$ & 2 & Blown battery, used No. 4 battery. \\
\hline $08 / 21 / 92$ & 3 & Low oil pressure, switch \& magnetic pickup not working. Both replaced. \\
\hline $09 / 08 / 92$ & 1 & Load controller (2301) burned-up. \\
\hline $09 / 09 / 92$ & 1 & Replaced load controller with 2301A. \\
\hline $09 / 11 / 92$ & 1 & Engine would not run. Broken magento drive. \\
\hline 09/22/92 & 4 & $\begin{array}{l}\text { After rebuilding left carburetor engine shutdown during testing. The } \\
\text { Murphy vibration switch bumed. }\end{array}$ \\
\hline $09 / 25 / 92$ & 4 & Safety switch installed. \\
\hline $09 / 29 / 92$ & 2 & $\begin{array}{l}\text { Can't control engine speed \& could not load. Found short in wiring from } \\
\text { magnetic pickup. Replaced wiring. }\end{array}$ \\
\hline $10 / 22 / 92$ & 4 & $\begin{array}{l}\text { AFRC circuit board pulled from No. 3. Board repaired \& installed in No. } \\
3 \text {. }\end{array}$ \\
\hline $11 / 04 / 92$ & 4 & $\begin{array}{l}\text { Magneto, engine running erratically. Pulled No. } 3 \text { magento, installed } \\
\text { factory rebuilt magneto on No. } 3 \text {. }\end{array}$ \\
\hline $02 / 11 / 92$ & 3 & $\begin{array}{l}\text { Engine running erratically, switched No. } 2 \text { load controller \& replaced } \mathrm{O}_{2} \\
\text { sensor. }\end{array}$ \\
\hline $12 / 15 / 92$ & 2 & Replaced water line \& seals to aftercooler. \\
\hline
\end{tabular}


Table 1 (Continued)

JOB ORDERS

PENTEC SERVICES, INC.

\begin{tabular}{|c|c|l||}
\hline Date & Unit No. & \multicolumn{1}{c|}{ Description } \\
\hline $10 / 23 / 91$ & $3 \& 4$ & Repair / Replace speed switches. \\
\hline $10 / 24 / 91$ & 2 & Repair / Replace battery charger. \\
\hline $02 / 24 / 92$ & 3 & $\begin{array}{l}\text { Generator trip on reserve power \& engine speed varying too much to } \\
\text { load. }\end{array}$ \\
\hline $04 / 02 / 92$ & 4 & $\begin{array}{l}\text { Throttle control, no electrical control of engine speed from } \\
\text { switchboard. }\end{array}$ \\
\hline $04 / 02 / 92$ & 4 & Repaired throttle control valve. \\
\hline $04 / 15 / 92$ & 3 & Troubleshoot, engine will not crank enough to start. \\
\hline $06 / 24 / 92$ & 2 & Fix leaking water jacket pump. \\
\hline $11 / 09 / 92$ & 4 & AFRC is erratic in operation. \\
\hline $12 / 10 / 92$ & 2 & Repair / Adjust cooling water ling. \\
\hline $12 / 16 / 92$ & 3 & Repair / Adjust engine without overexhausting \& tripping off-line. \\
\hline
\end{tabular}


TABLE 2. CONTACTS FOR TECHNICAL INFORMATION

1. Navy Public Works Center

P .O. Box 368113

2730 McKean St., Ste 1

San Diego, CA 92136-5294

$\begin{array}{ll}\text { Richard Imel } & (619) 545-8615 \\ \text { Norman Groth } & (619) 556-7988 \\ \text { John Thomas } & (619) 556-7989\end{array}$

2. Woodward Governor Co.

P. O. Box 1519

Fort Collins, CO 80522

Wade Edgar

(303) 482-5811

3. Gerhardt's, Inc.

2001 Palma Drive

Ventura, CA 93003

$$
\text { James Wimp }
$$

(805) 658-2877

4. Mechanical Equipment, Inc.

P. O. Box 1800

Midland, TX 79702

Thomas Smith

(915) 687-0601

5. Caterpillar, Inc.

100 N.E. Adams

Peoria, IL 61629

Ken Smith

(309) 578-8117

6. Hawthorne Power System.s

8050 Othello Avenue

San Diego, CA 92111

Donald Lind

(619) 974-6885

7. Pentech Services, Inc.

9740 Scranton Road, Suite 150

San Diego, CA 92121

Robert M. Winn

(619) 457-2911 


\section{EVALUATION OF COGENERATION PLANT \\ Naval Computer \& Telecommunication Center (NCTS) \\ Naval Air Station North Island (NASNI) \\ San Diego, California}

\section{Work Scope}

Task A Identification of Repair/Replacement Requirements of Existing System

Identify repair and replacement requirements necessary, with associated costs, to bring the existing cogeneration plant, engines and controls, up to an acceptable level of reliability, as intended in the original plant's design, such that up to all 4 engines can be maintained on-line for scenarios:

4. continuous operation

5. operate on-peak and semi-peak; back-up status off-peak

6. operate on-peak, back-up status off-peak and semi-peak

Task B Identification of Modification Requirements to Convert the Cogeneration Plant to Emergency Generator Status

Identify repair, replacement, and modification requirements necessary, with associated costs to convert the existing cogeneration plant, engine and controls, to a reliable emergency generator system for scenarios;

13. back-up generator status, providing both electrical and thermal back-up

14. back-up generator status, install boiler for thermal back-up

\section{Task A Engineering Estimates}

Repair/Replacement requirements for the existing system include the following components:

1. Replace the 2301 Load Sharing \& Speed Control, P/N 8271-706E-E with 2301A, P/N 9905020

Estimated Cost:

$\begin{array}{lllr}\text { Material: } & \$ 1,200 / \text { unit X 4 } & = & \$ 4,800 \\ \text { Labor: } & 40 \mathrm{hr} \text { total @ \$75/hr } & = & 3,000 \\ \text { Travel \& subsistence: } & \$ 125 / \text { day X 5 days } & = & \frac{625}{} \\ & & & \$ 8,425\end{array}$


2. Replace Engelhard Air Fuel Ratio Controller (AFRC), Series 2SG Estimated Cost:

$\begin{array}{llll}\text { Material: } & \$ 6,575 / \mathrm{unit} X 4 & = & \$ 26,300 \\ \text { Labor: } & 64 \mathrm{hr} \text { total @ } \$ 75 / \mathrm{hr} & = & 4.800 \\ \text { (includes commissioning of first unit) } & & \$ 31,100\end{array}$

3. Service and Tune-Up Woodward Governor Actuator, Model No. EG-3P, P/N E8250-553, Caterpillar Engine, Switch Gear \& Rewire Electrical and Instrumentation

\section{Estimated Cost:}

Wiring \& misc. materials: $\$ 1,500 /$ unit X $4=\$ 6,000$

Labor:

$10 \mathrm{hr}$ total at $\$ 75 / \mathrm{hr}=\frac{9.000}{\$ 15,000}$

Total $=\$ 15,000$

Total Cost $=\$ 8,425+\$ 31,100+\$ 15,000=\$ 54,525$

In order to determine operation and maintenance requirements of the cogen units, the following information is supplied:

Caterpillar Engine, Natural Gas Fueled. Model G399TA, Rich Burn Rated at $650 \mathrm{~kW}$

Output: $600 \mathrm{~kW}$

Engine No.

1

2

3

4
Serial No. $49 \mathrm{C} 01426$ $49 \mathrm{C} 01428$ $49 \mathrm{C} 01429$ $49 \mathrm{C} 01427$
Total Run Time, hr (Through Mid-March, 1993)

21,025

23,724

21,985

21,564

Scenario No. 4. Continuous

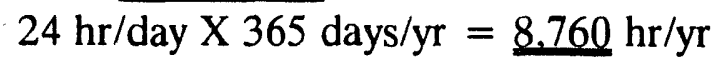

Scenario No. 5. On- \& Semi-Peak

Summer $\&$ winter hours: 6 a.m. to 10 p.m. $=16 \mathrm{hr}$ plus $1 / 2 \mathrm{hr}$ lead \& $1 / 4 \mathrm{hr}$ lag $=16.75 \mathrm{hr} /$ day

Summer \& winter days $=110-3+150-5=252$

Total $=252 \times 16.75=4.221 \mathrm{hr} / \mathrm{yr}$

$\%$ of year $=(4221 / 8760) 100=48.2 \%$ 
Scenario No. 6. On-Peak

Summer hours: 11 a.m. to 6 p.m. $=7+.75=7.75 \mathrm{hr} /$ day

Hours/year $=107 \times 7.75=829$

Winter hours: 5 p.m. to 8 p.m. $=3+.75=3.75 \mathrm{hr} /$ day

Hours/year $=145 \times 3.75=544$

Total $=\underline{1373} \mathrm{hr} / \mathrm{yr}$

$\%$ of year $=(1373 / 8760) 100=15.7 \%$

The present maintenance contract (N68711-90-D-8335) with Pentech Services, Inc. is summarized below (Table 3 ).

\begin{tabular}{|c|c|c|}
\hline Code & Item & Cost \\
\hline 0005 & Preventive Maint. (P.M.) cost/mo & $\$ 7,683$ \\
\hline 0006 & $\begin{array}{l}\text { Unscheduled maint. \& service } \\
\text { calls, cost } / y r\end{array}$ & 9,600 \\
\hline 0007 & $\begin{array}{l}\text { Major scheduled overhaul } \\
\text { (every } 30,000 \mathrm{hr} \text { ) }\end{array}$ & 30,376 \\
\hline 0008 & Materials, cost/yr & 50,000 \\
\hline Added & Top-end overhaul (every $10,000 \mathrm{hr}$ ) & 10,000 \\
\hline
\end{tabular}

Costs for Codes 0005, 0006, and 0007 escalate as follows:

\begin{tabular}{|c|c|c|}
\hline Code & 2nd year & 3rd year \\
\hline 0005 & $4.75 \%$ & $4.83 \%$ \\
\hline 0006 & $3.75 \%$ & $4.22 \%$ \\
\hline 0007 & $3.75 \%$ & $3.78 \%$ \\
\hline
\end{tabular}

The estimated maintenance costs are as follows:

$\underline{\text { Scenario }}$

4
5
6

\section{Maintenance Cost}

Same as present cost

$48.2 \%+20 \%=68.2 \%$ of present cost

$15.7 \%+30 \%=45.7 \%$ of present cost 
The Navy Public Works Centers (NPWC) Operation and Maintenance staff can also be reduced for Scenarios 5 and 6 . This estimate is as follows:

Scenario

$\begin{array}{ll}4 & \text { No change } \\ 5 & 30 \% \text { reduction } \\ 6 & 50 \% \text { reduction }\end{array}$

\section{NPWC Staff Reduction}

No change

$30 \%$ reduction

\section{Task B}

The estimated cost to convert the existing cogen plant is as follows:

1. Cost of Task $\mathrm{A}=\$ 54,525$

2. Conversion of controls to backup (emergency) generator system and servicing/checkout of existing switchgear and breakers is approximately $\$ 10,000$.

Scenarios 13 and 14 Back-up Gene. Itor Status

1. Operational Check With Load:

Once a month for $2 \mathrm{hr}$

$2 \mathrm{hr} / \mathrm{mon} \times 12 \mathrm{mon} / \mathrm{yr}=24 \mathrm{hr} / \mathrm{yr}$

2. Operational Check Without Load:

Once a week for $1 \mathrm{hr}$, less 1 week per month (with load check). $1 \mathrm{hr} / \mathrm{week}$ X $40 \mathrm{wk} / \mathrm{yr}=40 \mathrm{hr} / \mathrm{yr}$

3. Estimated Run Time per Year $=100 \mathrm{hr} / \mathrm{yr}$

Total $=24+40+100=162 \mathrm{hr} / \mathrm{yr}$

$\%$ of year $=(162 / 8760) 100=2 \%$

\section{General Notes:}

1. The estimated total useful life for each unit is $120,000 \mathrm{hr}$. The remaining useful life (with proper operation and maintenance) would still be almost $100,000 \mathrm{hr}$ for all 4 units.

2. Their salvage value is presently estimated at $\$ 50,000$ each.

3. Building 1482 , NCTS presently uses the thermal energy from only cogen 2 units for their absorption units. Any additional heat would have to be disposed using their cooling towers. 


\section{Distribution}

No. of

Copies

Onsite

12 DOE/Office of Scientific and Technical Information

2 K. Dean Devine

Federal Energy Management Program

U.S. Department of Energy

EE-44

1000 Independence Avenue SW

Washington, DC 20585

M. Ginsberg

Federal Energy Management Program

U.S. Department of Energy

EE-44

1000 Independence Avenue SW

Washington, DC 20585

2 L. Harris

Federal Energy Management Program

U.S. Department of Energy

EE-44

1000 Independence Avenue SW

Washington, DC 20585

V. Petrolati

DOE/In-House Energy Management

U.S. Department of Energy

1000 Independence Avenue SW

Washington, DC 20585

J. Ashley

NAVFAC Code 135A

200 Stoval Street

Alexandria, VA 22332-2300
No. of

Copies

Orfite

F. Beason

U.S. Air Force

Civil Engineering Suppurt Agency

HQ AFCESA/ENM

139 Barnes Drive

Tyndall AFB, FL 32403-5319

M. Carr

U.S. Department of Defense

Office of Secretary of Defense

DASD (L) EP

The Pentagon

Washington, DC 20301-8000

J. Heller

Naval Facilities Engineering Service Center

Code 111E2

Port Hueneme, CA 93043-5014

R. K. Hoshide

Rockwell

Energy Technology Engineering Ctr. TO38

P.O. Box 7930

Canoga Park, CA 91309-7930

3 R. Miner

Southwest Division, Naval

Facilities Engineering Command

Code 1632RM

1220 Pacific Highway

San Diego, CA 92132-5910

3 J. W. Thomas

Navy Public Works Center San Diego

PWC Code 650, Box 368113

2730 McKeen Street, Suite 1

San Diego, CA 92136-5113

Distr.1 
No. of

Copies

R. Torres

Southwest Division, Naval Facilities

Engineering Command

Code 16

1220 Pacific Highway

San Diego, CA 92132-5910

Onsite

DOE Richland Operations Office

D. D. Green

K8-50

29 Pacific Northwest Laboratory

C. A. Anderson

K5-20

R. Bartlett

K8-15

D. R. Brown

K6-61

D. M. Carroll (3)

K5-08

J. W. Currie

K8-54

K. K. Daellenbach

K6-61

K. L. McMordie

K5-08

G. B. Parker (5)

K7-82

S. A. Parker (3)

K5-08

D. R. Payson

K7-90

N. J. Reed, Project File (2)

W. F. Sandusky

K5-20

S. A. Shankle

K5-06

D. J. Stucky

K6-57

Publishing Coordination

K6-57

Technical Report Files (5)

K1-06

P8-55 

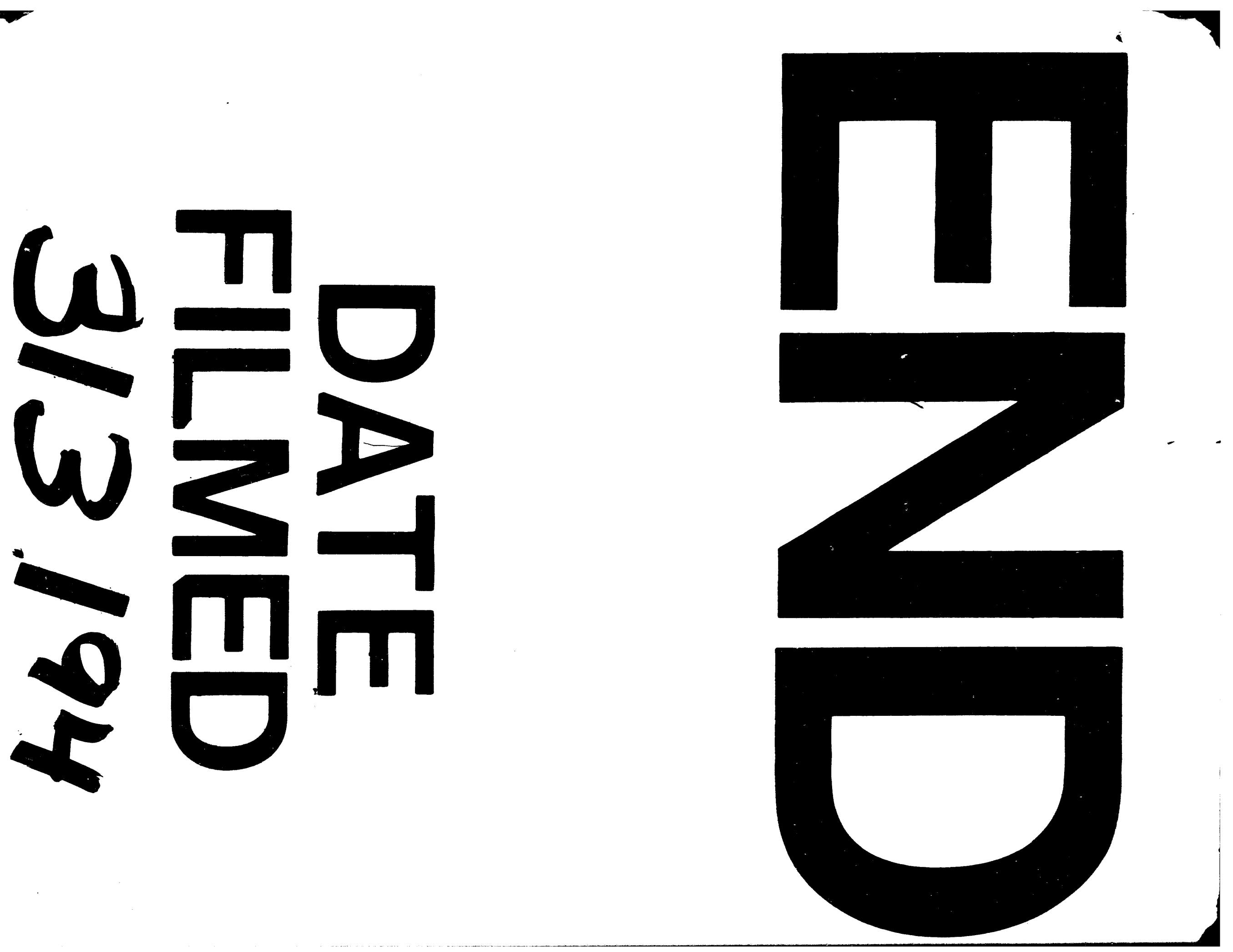
